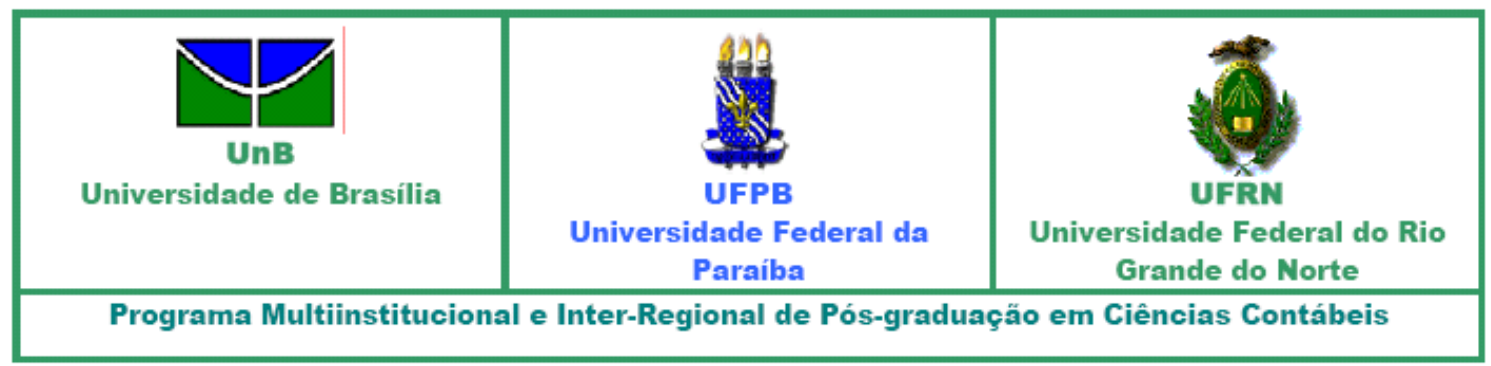

UNIVERSIDADE DE BRASÍLIA

UNIVERSIDADE FEDERAL DA PARAÍBA

UNIVERSIDADE FEDERAL DO RIO GRANDE DO NORTE

JOSICARLA SOARES SANTIAGO

UM ESTUDO SOBRE O IMPACTO DO PROCESSO DE CONVERGÊNCIA DAS PRÁTICAS CONTÁBEIS NO RISCO SISTÊMICO 
JOSICARLA SOARES SANTIAGO

\title{
UM ESTUDO SOBRE O IMPACTO DO PROCESSO DE CONVERGÊNCIA DAS PRÁTICAS CONTÁBEIS NO RISCO SISTÊMICO
}

\begin{abstract}
Tese apresentada ao Programa Multi-Institucional e Inter-Regional de Pós-Graduação em Ciências Contábeis da Universidade de Brasília, Universidade Federal da Paraíba e Universidade Federal do Rio Grande do Norte, como requisito parcial à obtenção do título de Doutora em Ciências Contábeis.
\end{abstract}

Orientador: Dr. Paulo Roberto Nóbrega Cavalcante.

Área de Concentração: Mensuração Contábil

Linha de Pesquisa: Contabilidade e Mercado Financeiro

\section{JOÃO PESSOA}


S235u Santiago, Josicarla Soares.

Um estudo sobre o impacto do processo de convergência das práticas contábeis no risco sistêmico / Josicarla Soares Santiago.- João Pessoa, 2016.

174f. : il.

Orientador: Paulo Roberto Nóbrega Cavalcante Tese (Doutorado) - UnB-UFPB-UFRN

1. Contabilidade. 2. Risco sistêmico. 3. Beta. 4. IFRS.

5. Variáveis contábeis. 6. Informação contábil - qualidade. 


\section{UM ESTUDO SOBRE O IMPACTO DO PROCESSO DE CONVERGÊNCIA DAS PRÁTICAS CONTÁBEIS NO RISCO SISTÊMICO}

Tese submetida à apreciação da banca examinadora do Programa Multi-Institucional e InterRegional de Pós-Graduação em Ciências Contábeis da Universidade de Brasília, Universidade Federal da Paraíba e Universidade Federal do Rio Grande do Norte, como requisito parcial à obtenção do grau de Doutora em Ciências Contábeis.

Aprovada em 12/07/2016.

Dr. Paulo Roberto Nóbrega Cavalcante Orientador-Presidente

Universidade Federal da Paraíba - UFPB

Dr. Paulo Amilton Maia Leite Filho

Membro Interno Vinculado - UnB/UFPB/UFRN

Universidade Federal da Paraíba - UFPB

Dr. Márcio André Veras Machado

Membro Interno Vinculado - UnB/UFPB/UFRN

Universidade Federal da Paraíba - UFPB

Dr. Odilanei Morais dos Santos

Membro Externo Não Vinculado

Universidade Federal do Rio de Janeiro - UFRJ

Raimundo Nonato Rodrigues

Membro Externo Não Vinculado

Universidade Federal de Pernambuco - UFPE 
Aos meus Pais -

Para quem deu tudo de si, sem nada pedir, meu mais profundo amor e gratidão. 


\section{AGRADECIMENTOS}

"Quero louvar o Senhor com toda a minha alma, sem esquecer nenhum dos seus benefícios" (SALMO, 103:2). Foi longa e intensa a jornada, mas o meu Deus nunca me desamparou, sempre me deu forças e entendimento para compreender que para os que confiam, depois do gosto amargo, sempre vem o doce da vitória.

Agradeço aos meus Pais (Antônio e Maria José), verdadeiros anjos em minha vida, que acompanham, com toda acepção da palavra, cada passo meu. Torcem pela minha vitória como se fossem deles, compreendem minhas ausências e dão o suporte necessário para que tudo que eu faça seja possível. Vocês são a minha maior riqueza.

Ao meu noivo Artur Felipe, que desde o primeiro dia dessa jornada esteve presente em minha vida, acompanhando e incentivando a concretização desse objetivo. Sua atenção e carinho foram essenciais para que o fardo fosse mais leve em alguns momentos.

Ao professor Dr. Paulo Cavalcante, pela orientação e conhecimento transmitidos, e não posso esquecer da paciência, que em tantos momentos me acalmou e me fez ver que eu era capaz. Sua forma de conduzir a orientação foi basilar para que o aprendizado acontecesse sem tantos traumas. Muito obrigada.

Ao professor Dr. Edilson Paulo por ter participado ativamente da formação da ideia que sustenta esse trabalho, assim como, por todas as discussões na disciplina de Teoria Positiva que foram extremamente ricas para formação teórica presente nessa pesquisa.

Aos professores Dr. Anderson Mól, Dr. Orleans Martins, Dra. Umbelina Torres e Dr. Márcio Machado pelas contribuições sugeridas quando na fase de projeto dessa pesquisa.

Ao programa Multi-institucional e Interregional de Pós-Graduação em Ciências Contábeis UnB, UFPB e UFRN, nas pessoas dos professores coordenadores Jorge Katsumi (UnB) e Dr. Edilson Paulo (UFPB), por proporcionarem o andamento de cursos que contribuem para o desenvolvimento da ciência contábil. E agradeço ainda as secretarias do programa que sempre nos atenderam prontamente, em especial a Ivanacy, Wilma e Inês.

A todos os professores que muito contribuíram transmitindo seus conhecimentos durante as disciplinas por mim cursadas: Dr. Ivan Gartner, Dr. César Tibúrcio, Dr. José Matias, Dr. Anderson Mól, Dr. Jorge Katsumi, Dr. Paulo Lustosa, Otávio Ribeiro, Ph.D, Dr. Edilson Paulo, Dr. José Dionísio e Dr. Paulo Cavalcante.

À Universidade Federal da Paraíba por incentivar a capacitação de seus professores, em especial ao Departamento de Ciências Sociais Aplicadas (Campus IV), por permitir o meu afastamento na fase mais crítica que foi a elaboração da tese, sempre tendo recebido o incentivo 
de todos os colegas, e em especial aos professores: Esp. Fábio Lira, Dr. José Jassuípe e Ms. João Marcelo, por terem se comprometido em eventuais necessidades me substituírem.

A minha turma, Turma 5: Adriana Isabel, Daniel Falcão, Diego Boente, Gilmara Mendes, Leonardo José, Lidiane Nazaré, Lucio Tozetti, Luiz Carlos, Marcia Tavares e Mateus Alexandre. Com essa turma aprendi, sorri e chorei (mais sorri que chorei, se sorria até da própria desgraça). Vocês deixaram a árdua caminhada, mais leve. Certamente, vocês já estão dentro do grupo de amigos que levarei pela vida inteira.

Aos meus amigos e familiares em geral, que mesmo alguns deles às vezes não entendendo as nuances do desenvolvimento desse processo, sempre incentivava e apoiava à chegada a reta final. Nas pessoas de Adriana Isabel, Josilene Tibúrcio e Fabiano Batista destaco a participação dos amigos. Sempre dispostos a me ouvir e apresentar uma palavra amiga, nossas conversas sempre foram revigorantes.

À Fabiano Batista, quero ainda reforçar, que embora não tenhamos cursado doutorado juntos, mas muitas vezes parecia que fazíamos o mesmo curso, sempre compartilhando coisas novas que estudávamos, pontos interessantes que encontrávamos em nossas leituras, enfim, durante todo esse tempo, nossas discussões me agregaram muito conhecimento. Você é um amigo muito especial.

Enfim, a todos que, direta e indiretamente, proporcionaram a minha chegada até aqui. 
Nunca temos certeza.

Somos sempre ignorantes em certo grau. (Peter L. Bernstein) 


\section{RESUMO}

Este trabalho analisou a influência da adoção das IFRS no risco sistêmico. Foram assumidos os seguintes pressupostos principais: A adoção da IFRS pode afetar as informações contábeis e provocar efeito sobre a sua qualidade; e a informação contábil tem relação com o risco sistêmico. Nesse sentido, foram definidos, como amostra, os seguintes países: Canadá; França; Alemanha; Reino Unido; Itália; Brasil; Rússia; China; África do Sul; Nova Zelândia e Austrália. Assim, para a estimação dos Betas dinâmicos dos mercados, representantes do risco sistêmico, foram coletados os índices de mercado principais dos 11 países estabelecidos como amostra. Para isso, utilizou-se o modelo GARCH no período de janeiro de 2000 a setembro de 2015. Para o entendimento das relações entre os Betas estimados para os países em estudo se usou de estatística descritiva de matriz de correlação. No estudo do Beta estimado no Pré e Pós-IFRS, assim como para a análise do efeito de variáveis controle (Taxa de Juros e Taxas de Câmbio) foi utilizada a regressão quantílica. Com o intuito de testar o Pré e Pós-IFRS como variável resposta, sendo esta uma variável binária, se aplicou a regressão logística. Os resultados deste trabalho apontam indícios de que a adoção das IFRS afeta o risco, pois, embora o risco não tenha sido afetado na mesma direção para todos os países, houve diferença estatisticamente significantes para a maioria. Observou-se, ainda, que os países se comportam diferentemente com relação ao Pós-IFRS - o que pode ser justificado por aspectos culturais e econômicos não estudados nesta pesquisa. Investigou-se, também, o impacto sobre o risco das variáveis Taxa de Câmbio e Taxa de Juros e se verificou que, na maioria das vezes, não existe alteração no efeito do Pós-IFRS. Verificando-se, através da aplicação da Análise Fatorial, que as variáveis contábeis impactantes foram de diversas ordens dentro do patrimônio da firma, o que pode ser justificado pela abrangência das alterações propostas pelo modelo Pós-IFRS, ao se aplicar a regressão logística, encontrou-se que o Pós-IFRS traz inferências acerca de um possível aumento do conteúdo informacional da Contabilidade e de uma provável diminuição no risco. Desta forma, depreende-se, como pontos principais, que sistemas contábeis estão transitando para o fornecimento de informações mais transparentes com uma maior capacidade informacional das variáveis contábeis e que o beta (risco de mercado) tem a possibilidade de integrar o rol das proxies de estudo da qualidade da informação contábil.

Palavras-Chave: Risco Sistêmico. Beta. IFRS. Qualidade da Informação Contábil. 


\begin{abstract}
This research aimed at analyzing the influence of IFRS adoption on the systemic risk. The IFRS adoption might affect accounting information and cause effect on the quality; and the accounting information is related to the systemic risk. In this case, some countries were definied as samples, such as: Canada, France, Germany, United Kingdom, Italy, Brazil, Russia, China, South Africa, New Zealand, and Australia. Thus, to estimate dynamic Beta of markets, which are representatives of the systemic risk, main market indicators in those eleven countries envolved were collected. To do so, the GARCH model was used in the period from January 2000 to September 2015. To come to understand the relations among the estimate Betas for the countries envolved, this study used descriptive statistics of correlation matrix. In order to test the pre- and post-IFRS as variable response, this being a binary variable, the logistic regression was applied. The results found indicate that the IFRS adoption affects the risk, once that, altough the risk had not been affected towards the same direction for all countries envolved, there was a statistically significant difference for most of them. It was also observed that the countries behave differently with respect to post-IFRS - what might be justified by cultural and economical aspects not observed in this study. It was also investigated the impact on the risks of Exchange Rate and Interest Rate variables and it was observed that, in most of the cases, there is no alteration in the effect of post-IFRS. It was verified, through the factorial analysis, that the impacting accounting variables were demonstrated in different ways in the company's assets, what might be justified by the coverage of alterations proposed by the post-IFRS model, upon applying the logistic regression, it was found that the post-IFRS bring interferences on a probable increase of the accounting informational content, as well as a probable decrease in risk. Thus, it is undertood that, as main remarks, accounting systems are in transit to offer more transparent information with a higher informational capability of accountng variables and Beta (market risk) is likely able to be added to the proxies of qualitative studies of accounting information.
\end{abstract}

Keywords: Sistemic Risk. Beta. IFRS. Accounting Information Quality. 


\section{LISTA DE FIGURAS}

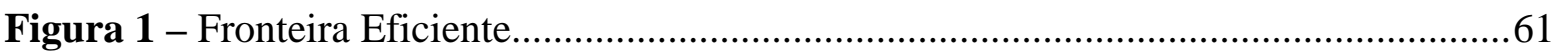

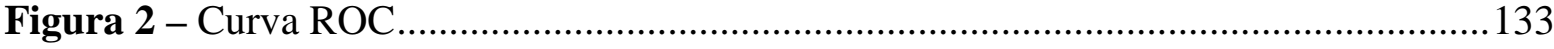




\section{LISTA DE GRÁFICOS}

Gráfico 1 - Comportamento Médio do Beta no Conjunto dos Dados (Por país) .................102

Gráfico 2 - Comportamento Médio do Beta com e sem Presença da IFRS (por país) ........ 104

Gráfico 3 - Autovalor para o critério de teste Scree ........................................................126

Gráfico 4 - Comportamento dos países com Relação ao Índice Médio na Perspectiva de Ausência e de Presença das IFRS ................................................................. 131 


\section{LISTA DE QUADROS}

Quadro 1 - Relação entre o risco sistêmico e o risco de mercado .......................................64

Quadro 2 - Pesquisas do tema Risco x Informação contábil ................................................78

Quadro 3 - Situação em Relação as Companhias Listadas nos países Participantes do

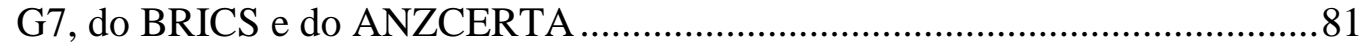

Quadro 4 - Sequência estabelecida para o Cálculo dos Betas segundo os índices dos

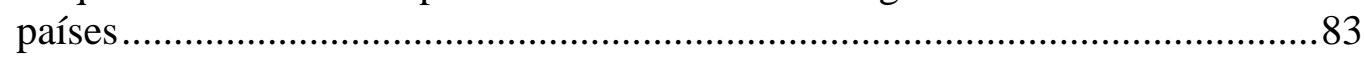

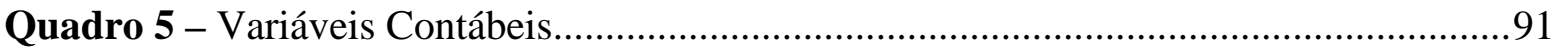




\section{LISTA DE TABELAS}

Tabela 1 - Avaliação Qualitativa do Grau de Correlação entre Duas Variáveis 87

Tabela 2 - Medida de Adequação da Amostra (KMO-MSA) ............................................93

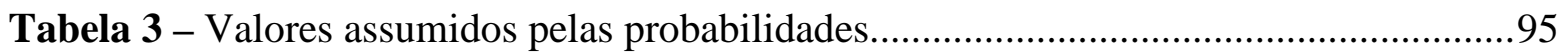

Tabela 4 - Estatística descritiva dos Betas Estimados .......................................................98

Tabela 5 - Média e Mediana segregada por país (Amostra Total) .................................... 100

Tabela 6 - Média e Mediana dos Betas segregadas por país (subdivisões) ......................... 103

Tabela 7 - Teste Ed t-Student para Estudo do comportamento do Beta por país e com a presença da IFRS

Tabela 8 - Matriz de Correlação dos Betas Estimados entre os países .............................. 106

Tabela 9 - Regressão Quantílica dos países em estudo - Beta (Variável Dependente) e Dummy (Variável Independente) ................................................................109

Tabela 10 - Regressão Quantílica da Austrália - Beta (Variável Dependente) e Dummy, Taxa de Juros e Taxa de Câmbio (Variáveis Independentes).

Tabela 11 - Regressão Quantílica da Alemanha - Beta (Variável Dependente) e Dummy, Taxa de Juros e Taxa de Câmbio (Variáveis Independentes) ...........................111

Tabela 12 - Regressão Quantílica do Brasil - Beta (Variável Dependente) e Dummy, Taxa de Juros e Taxa de Câmbio (Variáveis Independentes).

Tabela 13 - Regressão Quantílica da China - Beta (Variável Dependente) e Dummy,

Taxa de Juros e Taxa de Câmbio (Variáveis Independentes).

Tabela 14 - Regressão Quantílica da Canadá - Beta (Variável Dependente) e Dummy, Taxa de Juros e Taxa de Câmbio (Variáveis Independentes)

Tabela 15 - Regressão Quantílica do Reino Unido - Beta (Variável Dependente) e Dummy, Taxa de Juros e Taxa de Câmbio (Variáveis Independentes) .

Tabela 16 - Regressão Quantílica do Itália - Beta (Variável Dependente) e Dummy,

Taxa de Juros e Taxa de Câmbio (Variáveis Independentes).

Tabela 17 - Regressão Quantílica da França - Beta (Variável Dependente) e Dummy,

Taxa de Juros e Taxa de Câmbio (Variáveis Independentes).

Tabela 18 - Regressão Quantílica da Nova Zelândia - Beta (Variável Dependente) e

Dummy, Taxa de Juros e Taxa de Câmbio (Variáveis Independentes)....

Tabela 19 - Regressão Quantílica da Rússia - Beta (Variável Dependente) e Dummy, Taxa de Juros e Taxa de Câmbio (Variáveis Independentes)....

Tabela 20 - Regressão Quantílica da África do Sul - Beta (Variável Dependente) e

Dummy, Taxa de Juros e Taxa de Câmbio (Variáveis Independentes).

Tabela 21 - Beta (Variável Dependente) e Dummy (Variável Independente).....

Tabela 22 - Beta (Variável Dependente) e Dummy, Taxas de Juros e Taxas de Câmbio

(Variável Independente). 
Tabela 23 - KMO com todas as variáveis selecionadas

Tabela 24 - Medidas estatísticas para a validação da Análise Fatorial do instrumento com o Método das Componentes Principais (Principal Conponent Analysis) .126

Tabela 25 - Cargas fatoriais para os quatro fatores do modelo de Análise Fatorial 127

Tabela 26 - Medidas descritivas por Dummy e países para os valores do Índice e sua comparação com o teste Ed t-Student

Tabela 27 - Teste geral (omnibus test) de Significância - Modelo Chi-Square 132

Tabela 28 - Sumário do Modelo 133

Tabela 29 - Teste Hosmer e Lemeshow.... 133

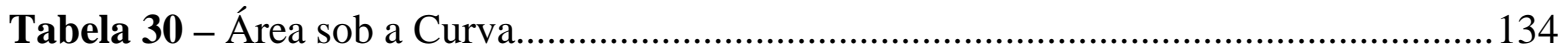

Tabela 31 - Variáveis na Equação.............................................................................. 135

Tabela 32 - Estimação dos parâmetros da regressão logística binária com variável dependente ausência ou presença da IFRS 135

Tabela 33 - Classificação do Índice e do Beta por Tabulação Cruzada. 136 


\section{LISTA DE ABREVIATURAS E SIGLAS}

AAA American Accounting Association

AF Análise Fatorial

AICPA American Institute of Certified Public Accountants

AISG Accountants International Study Group

ANZCERTA Australia New Zealand Closer Economic Relations Trade Agreement

APT Arbitrage Pricing Theory

ARCH Autoregressive conditional heterocedasticity

ASOBAT A Statement of Basic Accounting Theory

BRICS Brazil, Russia, India, China, South Africa

CAPES Coordenação de Aperfeiçoamento de Pessoal de Nível Superior

CAPM Capital Asset Pricing Model

DFC Demonstração dos Fluxos de Caixa

DOAR Demonstração das Origens e Aplicações de Recursos

F1 Fator 1

FASB Financial Accouting Standards Board

FCOPA Fluxo de Caixa Operacional

G7 Grupo dos 7

GAAP Generally Accepted Accounting Principles

GARCH Generalized Autoregressive conditional heterocedasticity

HME Hipótese de Mercado Eficiente

IASB International Accounting Standards Board

IASC International Accounting Standards Committee

IASCF International Accounting Standards Committee Foundation

IBCG Instituto Brasileiro de Governança Corporativa

ICAEW Institute of Chartered Accountants in England and Wales

ICCAP International Coordination Committee for Accounting Profession

IFRS International Financial Reporting Standards

KMO Kaiser-Meyer-Olkin

MMV Método da Máxima Verossimilhança

MSA Measure of Sampling Adequacy

MSCI Morgan Stanley Capital International

NDGC Níveis Diferenciados de Governança Corporativa 
OLS Ordinary Least Squares

PIB Produto Interno Bruto

ROC Receiver Operating Characteristic 


\section{SUMÁRIO}

1 INTRODUÇÃ

1.1 Contextualização.............................................................................................17

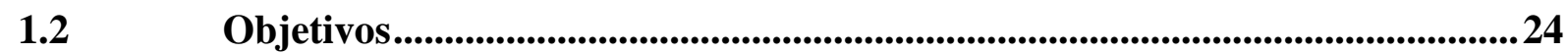

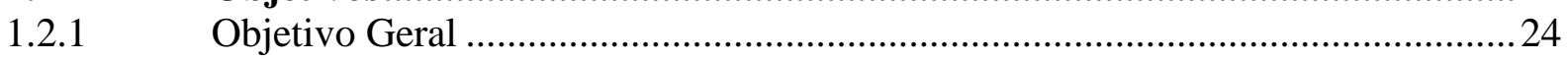

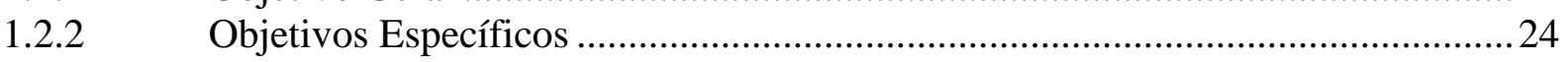

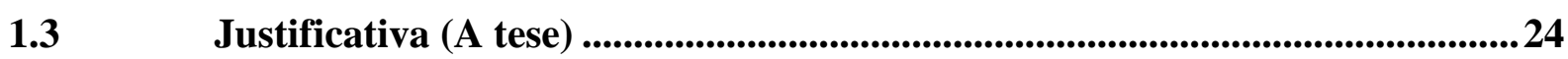

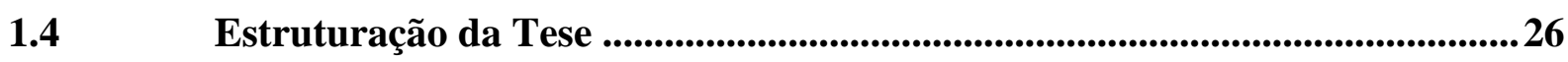

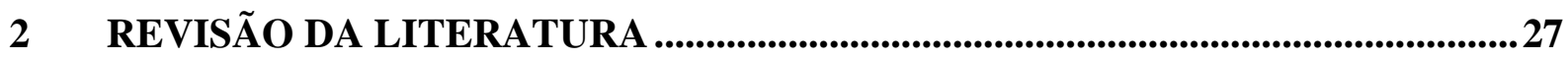

2.1 O Mercado Eficiente e a Influência das Informações Contábeis ....................27

2.2 Convergência Internacional das Práticas Contábeis......................................... 35

$2.3 \quad$ Variável Risco .............................................................................................5

$2.4 \quad$ Pesquisas Anteriores ..........................................................................................65

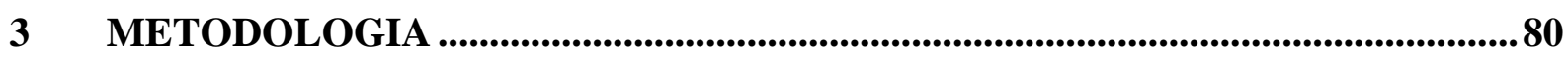

3.1 Modelo Econométrico.....................................................................................................8 80

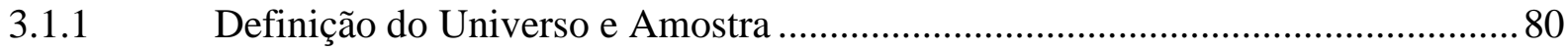

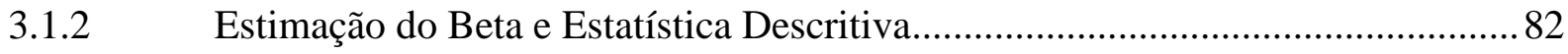

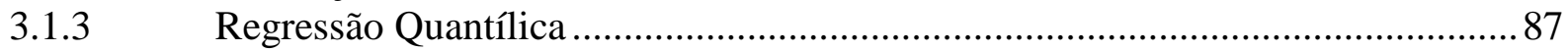

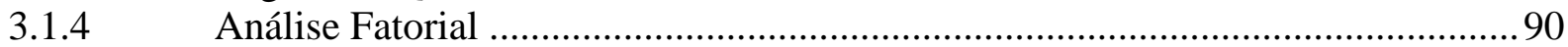

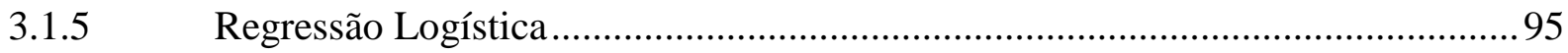

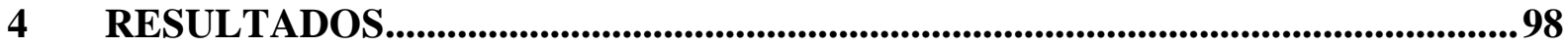

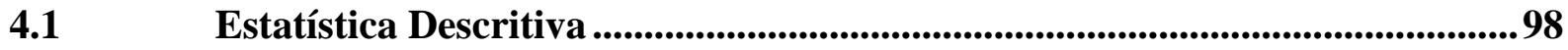

4.2 Teste da correlação entre os países ..........................................................105

Regressão Quantílica ......................................................................................................... 108

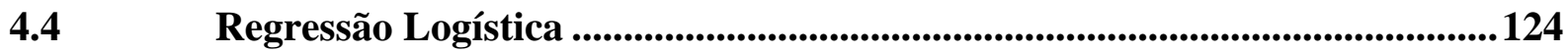

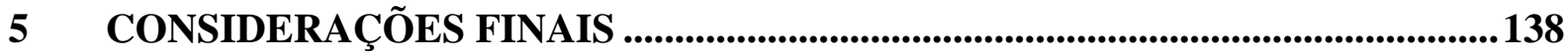

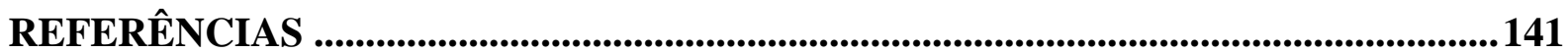

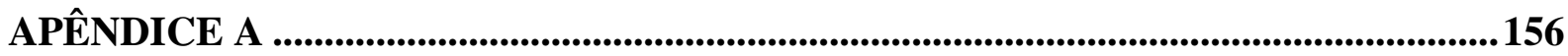

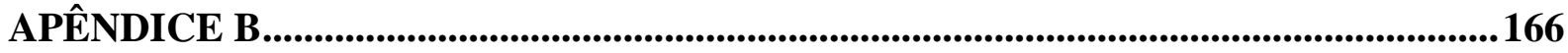

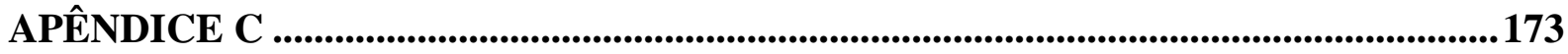




\section{INTRODUÇÃO}

\subsection{Contextualização}

A Hipótese do Mercado Eficiente, apresentada por Fama (1970) tem, entre seus pressupostos básicos, o fato de que os preços refletem o conteúdo informacional relevante disponível no mercado e, nesse sentido, no grupo de informações que são incorporadas ao preço inclui-se a informação contábil, sendo a Contabilidade, portanto, um meio de oferecer informações relevantes aos usuários.

A principal finalidade dos relatórios contábeis é fornecer informações úteis para potenciais investidores, credores e outros, a fim de ajudá-los no processo de tomada de decisões relacionadas com a entidade. Por isso, há a exigência de que as demonstrações contábeis sejam transparentes, confiáveis e comparáveis para que os tomadores de decisão possuam toda informação relevante ao seu alcance (AL-OMARI, 2010).

Com base no exposto, considerou-se a eficiência do mercado de capitais, no sentido de que seus preços reagem, instantânea e imparcialmente, a novas informações publicamente disponíveis que, portanto, as refletem.

Mas até que ponto os números contábeis representam os tipos de informação que são captadas pelo preço de mercado? Não se pode, é claro, esperar que números contábeis conjecturem todos os eventos refletidos nos preços correntes de mercado. Se uma peça economicamente significativa da legislação está em discussão, por exemplo, no Senado dos Estados Unidos, em seguida, os efeitos esperados desta legislação (se os houver) podem ser refletidos em preços correntes de mercado, talvez não instantaneamente, mas paulatinamente, podendo haver uma correlação entre as informações apreendidas em números contábeis e refletidas no preço de mercado (GONEDES, 1973).

Do exposto, percebe-se que a informação contábil é só um entre os vetores que impactam o preço das ações, pois o mercado reage a diversos outros fatores (taxas de juros, crises econômicas, políticas, entre outros) e o nível em que eles exercem impacto depende do momento em que são disponibilizadas no mercado e, mesmo havendo intempestividade, a validade da sua participação é confirmada, pois, no mínimo, haverá sinalização de algumas captações de ordem econômica ou financeira, já realizadas pelo mercado. A ideia é que o mercado incorpora a informação contábil anunciada, antecipadamente ao preço, o qual só sofreria alteração se houvesse mudanças de cenários no momento da divulgação. 
Para se comprovar que a informação contábil é refletida no preço de mercado, uma das principais ferramentas utilizadas se baseou na premissa de que os lucros contábeis são substitutos para os fluxos de caixas futuros, o que vem do próprio conceito de valor da empresa, que, conforme Watts e Zimmerman (1986), é resultante dos fluxos de caixa esperados e da respectiva taxa de retorno associada, relacionando-se os riscos inerentes à negociação. Isto posto, se as informações contábeis alterarem as expectativas em torno do fluxo de caixa, as taxas de retornos associadas serão modificadas e culminarão na alteração dos preços (FAMA, 1970).

Os lucros, por sua vez, refletem os fluxos de caixa projetados e possuem forte correlação com estes, ocupando uma posição central na Contabilidade, no qual, de fato, se no lucro de um determinado período há informações sobre o fluxo de caixa de referência, pode-se afirmar que o lucro contábil poderá fornecer informações a respeito do fluxo futuro de caixa (DECHOW; KOTHARI; WATTS, 1998).

Logo, tanto a informação do lucro como dos fluxos de caixa remetem ao desempenho da firma, o que representa o principal interesse do investidor e, portanto, são consideradas relevantes. Desta forma, quando a informação do lucro altera a expectativa sobre os fluxos de caixa, tem-se a incorporação desta ao preço da ação, alterando também o risco percebido, aqui compreendido como incerteza da ocorrência dos fluxos de caixa futuro.

Percebe-se, então, que os preços das ações (valor da firma) são direcionados pelos retornos futuros esperados e pelo risco associado, de modo que são totalmente dependentes destes, assim como das informações utilizadas para a formação de tais previsões.

Nessa lógica, é importante destacar que alterações nas práticas contábeis interferem nas negociações do mercado, posto que, em consequência do tratamento dado a alguns eventos, decorrem alterações no resultado contábil o que, por sua vez, impacta na expectativa quanto aos retornos. É fato que reconhecer ou não determinados itens no Balanço Patrimonial ou utilizar de um ou outro critério de mensuração pode afetar o preço da ação (valor da firma). Enfim, mudanças de procedimentos contábeis implicam em mudanças de cenários e a consequente alteração das expectativas dos investidores, dada a reação do mercado às informações disponíveis, incorporando-as ao preço das ações.

Em um mercado eficiente prenunciado por Fama (1970), a mudança na forma que a informação contábil chega ao mercado é imediatamente percebida pelo investidor que usa essa informação para precificar, de forma diferente, os ativos (BALL; BROWN, 1968; BEAVER, 1968; BROWN; KENNELLY, 1972; WATTS; ZIMMERMAN, 1986; DECHOW; KOTHARI; WATTS, 1998; KOTHARI, 2001; HOLTHAUSEN; WATTS, 2001). 
Alguns estudos têm investigado as reações do mercado no preço das ações às mudanças nas informações contábeis, tendo como intenção provar que estas têm conteúdo informacional e que exercem influência nas decisões dos investidores, como, por exemplo Ball e Brown (1968), Beaver (1968) e Brown e Kennelly (1972), demonstrando que a Contabilidade pode ser considerada uma das fontes de informações relevantes para investidores. Estes estudos têm tratado do value-relevance e seu foco é dado através da relação empírica entre o valor de mercado e os números contábeis. Desta forma, no momento que se determina que uma variável contábil tem value-relevance, significa que ela tem conteúdo informacional e que, portanto, altera o preço das ações, sendo capaz de atingir as expectativas dos agentes econômicos.

Ball e Brown (1968) tiveram, como objetivo geral, avaliar a utilidade dos números contábeis examinando o seu conteúdo informativo e tempestividade. Concluiram que, em relação ao teor das informações disponíveis sobre uma firma, metade ou mais é capturado a partir do lucro; assim, o preço dos títulos varia na mesma direção que os lucros contábeis, fato demonstrativo de que existe conteúdo informacional no lucro contábil. No entanto, entre os resultados encontrados, percebeu-se certa intempestividade na informação do lucro, como consequência do fato de que a maior parte de seu conteúdo ser capturada mais rapidamente pelos meios de comunicação, talvez com base na divulgação de relatórios intermediários.

Beaver (1968) examinou empiricamente a reação dos investidores frente aos anúncios de lucros, estudando os reflexos nos volumes de negociação e nos preços das ações ordinárias nas semanas antes do anúncio. O resultado encontrado foi que tanto o preço da ação quanto o volume de negociação reagem consideravelmente à informação contábil.

Brown e Kennelly (1972) estudaram a utilidade do lucro trimestral por ação e concluíram que a informação nele contida é útil, podendo ser usada a favor do investidor para predizer retornos anormais aos quais os lucros se relacionam. Além disso, verificou-se que a divulgação trimestral melhora a capacidade de predição da informação do lucro.

Watts e Zimmerman (1986) e Kothari (2001) também demonstraram que a informação contábil tem uma relação significativa, em certo nível, com o preço das ações, já que a informação relevante é refletida no preço.

Os estudos de value relevance, segundo Holthausen e Watts (2001), se apresentam em três focos principais: estudos de Associação Relativa, em que se associa o preço das ações com valores contábeis reconhecidos a partir de novos padrões propostos, comparando com os valores contábeis de padrões já existentes; estudos de Associação Incremental, em que se investiga se as informações contábeis são úteis em termos de explicar outras variáveis especificadas (valor das ações); e estudos do conteúdo Informacional Marginal, que analisa se 
determinados números contábeis adicionam informações relevantes disponíveis para um grupo de investidores.

Mais especificamente no que diz respeito aos estudos de Associação Relativa - que compara o value relevance antes e após a adoção de novos padrõs contábeis - faz-se necessário contextualizar que a inserção de padrões contábeis internacionais teve, como intuito, promover um alto grau de transparência e confiabilidade para informações contábeis e, por conseguinte, promover melhorias na dinâmica do funcionamento do Mercado de Capitais, dando início a um movimento mundial em busca da convergência internacional das normas de Contabilidade.

A internacionalização dos mercados vinha em processo contínuo de crescimento e trazia, com ela, a necessidade de se trabalhar com informações contábeis que proporcionassem a possibilidade de estabelecer um razoável processo de comunicação entre os mais diversos países (JERMAKOWICZ; GORNIK-TOMASZEWSKI, 2006; ZEGHAL; MHEDHBI, 2006) e padrões contábeis globais que primassem pela qualidade, no sentido de melhorar a capacidade de investidores em tomar decisões financeiras (SHIL; DAS; PRAMANIK, 2009). Dessa forma, o processo de convergência já não se mostrava um diferencial, mas sim uma necessidade para o bom funcionamento do mercado internacional, uma vez que a credibilidade da informação contábil aumentaria e proporcionaria um melhor fluxo de capital e investimento, resultando assim em desenvolvimento econômico.

Percebe-se, então, que as informações contábeis elaboradas com base em práticas contábeis nacionais já não satisfaziam as necessidades dos usuários, cujas decisões são tomadas em âmbito internacional (ZEGHAL; MHEDHBI, 2006) e, sendo a Contabilidade responsável por comunicar a situação econômica e financeira das entidades, ela se deparou com a necessidade de responder aos anseios do mercado de capitais globalizado para que houvesse uma linguagem comum em termos de informações contábeis, de forma que empresas que atuem em diversos países, não encontrem dificuldade no sistema de comunicação e que essa dificuldade não se constitua entrave na captação de recursos.

Nesse contexto, a busca pela harmonização contábil se intensificava e terminava por culminar no processo de convergência internacional de padrões contábeis e a criação de um órgão único, que hoje se configura no International Accounting Standards Board (IASB), revelou-se uma ação que apresentou bons resultados, visto que tem cada vez mais se fortalecido em termos estruturais, além de ter ganhado crescimento contínuo em termos de reconhecimento internacional dos padrões contábeis por ele elaborados (ARGENTO, 2008; SHIL; DAS; PRAMANIK, 2009; IFRSFOUNDATION, 2015). A adoção das International Financial 
Reporting Standards (IFRS) se efetivou em torno de 138 países e vem se mostrando um significante dispositivo de modificação da história contábil.

Dessa maneira, embora a implementação da IFRS seja heterogênea entre os países, os incentivos à divulgação dependem de vários fatores, entre eles, o ambiente institucional, o apego às similaridades em busca da harmonização e do alcance da comparabilidade.

Porém, as lições e os benefícios advindos desta legitimidade institucional ainda estão sendo discutidos, isto quanto às suas consequências econômicas, políticas, culturais, além da contribuição para a qualidade da informação contábil. Será que, de fato, a instituição que hoje adota as IFRS teve ganho? Quais as consequências econômicas da adoção da IFRS?

Diversas pesquisas empíricas têm procurado discutir como as IFRS têm alterado a qualidade da informação contábil, com destaque para os trabalhos de Leuz (2003); Barth et al. (2006); Van Der Meulen, Gaeremynck e Willekens (2007); Callao, Jarne e Laínez (2007); Barth, Landsman e Lang (2008); Daske et al. (2008); Li (2010); Iatridis (2010); Lee et al. (2010); Konstantinos e Athanasios (2011); Khanagha (2011); Qu, Fong e Oliver (2012); Landsman, Maydew e Thornock (2012); Kargin (2013); Glaum et al. (2013) e Nulla (2013).

$\mathrm{Na}$ realidade, os resultados dessas pesquisas não foram unânimes em comprovar que a adoção das IFRS tem produzido relatórios financeiros com maior qualidade. No entanto, boa parte desses estudos encontram indícios de melhoria na qualidade dos relatórios, demonstrando evidências de aumento na transparência, na comparabilidade, na liquidez do mercado, no conservadorismo, na persistência dos lucros e no value-relevance, com redução de gerenciamento de resultados, da assimetria informacional e do custo de capital. Assume-se, então, o pressuposto de que a adoção das IFRS pode afetar as informações contábeis e provocará efeito sobre a sua qualidade.

Sendo aqui remetida à linha de estudo de Bruggemann, Hitz e Sellhorn (2013), na qual se usa o termo "consequências econômicas" para denotar qualquer efeito da informação contábil sobre os valores das firmas e sobre a prosperidade daqueles que tomam decisões baseadas na informação contábil ou são afetados por tais decisões, dando foco especificamente ao investidor.

Assim, considerando os efeitos econômicos decorrentes da adoção das IFRS e que as informações contábeis são absorvidas pelo mercado a partir do momento que existe alteração nos procedimentos utilizados para elaborar essas informações, pressupõe-se que haverá efeito sobre a sua qualidade, de modo que o comportamento do usuário da informação será alterado.

Existe uma forte preocupação por parte do investidor quanto ao acesso à informação, destacando aqui a informação contábil, uma vez que o aumento de sua disponibilidade reduz a 
incerteza sobre o valor da empresa, além de reduzir a assimetria informacional (LEUZ; WYSOCKI, 2008). Desta forma, o investidor tem maior segurança quanto ao risco envolvido nos investimentos, trabalhando com maior eficiência diante das expectativas de retorno.

É necessário considerar, ainda, que as decisões financeiras não são tomadas em ambiente de total certeza com relação a seus resultados, em verdade, por estarem essas decisões fundamentalmente voltadas para o futuro, é imprescindível que se introduza a variável incerteza como um dos mais significativos aspectos no estudo das operações do mercado financeiro e, se essa incerteza puder ser quantificada por meio de uma distribuição de probabilidades dos diversos resultados previstos, diz-se, então, que a decisão está sendo tomada sob uma situação de risco.

Hill e Stone (1980) colocam que a capacidade de as medidas contábeis explicarem riscos sistêmicos é óbvia, ao mesmo tempo em que Lima, Ilha e Galdi (2009) destacam que as principais finalidades dos relatórios contábeis são possibilitar a seleção de ativos com capacidade de gerar retornos anormais e acessar aos parâmetros de risco envolvidos na transação.

Estudos como os de Beaver, Kettler e Scholes (1970), Hamada (1972), Gonedes (1973), Gonedes (1975), Beaver e Manegold (1975), Bowman (1979) e Hill e Stone (1980), assumem discussões do relacionamento da informação contábil com o risco sistêmico, indicando associações significativas entre variáveis contábeis e medidas de risco sistêmico. Assim, assume-se como segundo pressuposto que a informação contábil tem relação com o risco sistêmico.

Sabe-se, também, que fatores como a estratégia competitiva da firma, as barreiras à sua entrada no setor e o poder de barganha quanto aos seus clientes e fornecedores, afetam o seu risco. Contudo, esses conceitos econômicos não são observáveis diretamente, ou são difíceis de medir quantitativamente de um modo rotineiro, o que sugere a necessidade de proxies que são mensuráveis e prontamente disponíveis.

Do exposto, é pertinente perceber que a adoção das IFRS constitui uma decisão institucional coercitiva, especificamente de regulação dos padrões contábeis de cada país, o que implica que todos os agentes, especialmente as empresas que têm pretensão de negociar os seus valores mobiliários, estão sujeitos aos seus efeitos, sejam positivos ou negativos. Por isso, não existe, por parte da firma, a possibilidade de optar pela participação no processo de convergência das práticas contábeis, seu uso se torna obrigatório a partir da imposição dos órgãos reguladores do país. 
Desta forma, ao se considerar que a adoção das IFRS determina alterações nas práticas contábeis, todas as empresas são afetadas e não somente aquelas de um setor específico, passando a ser este um fator importante para a mensuração do risco, visto que não existe possibilidade de uma empresa gerenciá-lo objetivando reduzir seu impacto, pois todos os ativos serão afetados e todas as empresas também estarão propensas ao mesmo risco.

Dentro deste contexto, extrai-se o raciocínio de que, se o risco pode ser afetado pela qualidade da informação contábil, num momento em que esta tem sido afetada pela adoção das IFRS, espera-se que o risco também seja impactado pelas IFRS, ou seja, assume-se que há interações entre as IFRS, a qualidade da informação contábil e o risco, de maneira que a nova informação exercerá efeito imediato sobre o preço de um ativo, de modo a provocar alterações na relação risco-retorno.

A relação inferida entre qualidade da informação contábil e o risco deve-se ao fato de que o maior conteúdo informacional, decorrente da adoção das IFRS, assim como a redução da assimetria informacional, a maior persistência do lucro, menor conservadorismo e menor gerenciamento de resultados, diminui as incertezas a respeito do investimento, já que aumenta a probabilidade de decisões acertadas, diminuindo, consequentemente, o risco sobre a operação. Dessa forma, a ideia geral é a de que existe uma correlação negativa entre a qualidade da informação contábil e o risco.

$\mathrm{O}$ aumento da qualidade da informação contábil também aumenta a liquidez de mercado, alargando a base de investidores, posto que o bom funcionamento do mercado possibilita transações de maneira ordenada e rápida, reduzindo o risco e o custo de capital (DASKE et al., 2008).

Mesmo considerando que o Beta de mercado não seja determinado somente por dados contábeis, é razoável supor que eles refletem os fenômenos econômicos subjacentes que são os verdadeiros determinantes do Beta (MENSAH, 1992). Isto posto, a relação entre variáveis contábeis e os riscos sistêmicos pode ser logicamente explicado através de valores contábeis (JEON; KIM; LEE, 2006). Assim, para efeitos dessa pesquisa, o risco sistêmico se resume ao captado no Beta.

Assim sendo, a adoção das IFRS pode afetar a decisão do investidor, em termos das suas expectativas de risco, uma vez que estas produzem efeito sobre a informação contábil, que, por sua vez, reflete-se no risco sistêmico, de forma que, mesmo diante de estratégias de diversificação, este risco não será afetado, pois, de fato, responde a efeitos econômicos e macroeconômicos. 
Assim, o risco é, teoricamente, uma importante variável de decisão para os investidores, credores e gestores, demonstrando que a capacidade das informações contábeis para avaliá-lo é de particular importância (WOAN, 2001), principalmente quando se considera que novas normas contábeis alteram a qualidade da informação contábil e de seus reflexos no mercado.

Neste âmbito, se elaborou a seguinte questão problema: Qual a influência da adoção da IFRS no risco sistêmico?

\subsection{Objetivos}

\subsubsection{Objetivo Geral}

O objetivo geral deste trabalho é analisar a influência da adoção da IFRS no risco sistêmico.

\subsubsection{Objetivos Específicos}

a) Verificar o comportamento do risco nos períodos de pré e pós adoção da IFRS nos países individualmente e em seu conjunto;

b) Identificar as variáveis contábeis mais influentes nos períodos de pré e pós adoção da IFRS.

c) Verificar a interação e variação do risco sistêmico à adoção da IFRS.

d) Verificar a interação e variação das variáveis contábeis à adoção da IFRS.

\subsection{Justificativa (A tese)}

A Tese: A adoção da IFRS causa impacto no Risco Sistêmico.

O efeito sistêmico é aquele que afeta todos os agentes de um dado universo, independentemente das decisões deles. Por esse ângulo, a opção do país pela adoção das IFRS afeta todas as empresas que negociam seus valores no mercado, tendo em vista que o risco está associado a incertezas quanto ao futuro, cuja projeção se dá a partir de dados históricos, na medida em que as IFRS promovem uma maior qualidade das informações contábeis, mitiga as incertezas e, consequentemente, os riscos são diminuídos.

O risco é uma importante variável de decisão econômica para a maioria dos investidores, conforme é tratado no ASOBAT (A Statement of Basic Accounting Theory) (AAA (American 
Accounting Association, 1966, 4 e 19) ${ }^{1}$, um dos objetivos da Contabilidade é fornecer informações para "tomar decisões sobre o uso de recursos limitados" além de estas serem "o principal meio de reduzir a incerteza sob a qual os usuários externos atuam” (WOAN, 2001).

Partindo do pressuposto que a informação contábil afeta o risco, o estudo do valuerelevance e seus reflexos no risco resultarão em um feedback para os participantes do mercado de capitais, órgãos reguladores, bem como pesquisadores e professores de Contabilidade, sobre a utilidade dos números contábeis e do efeito da inserção de novas normas contábeis nas variações econômicas e macroeconômica.

Esta tese fornecerá, portanto, insights com relação ao papel do órgão normatizador na preservação da relevância das informações contábeis para o mercado de capitais e das consequências da escolha do país em se inserir no processo de convergência internacional das práticas contábeis, podendo contribuir para a elaboração de normas. Além disso, o pressuposto que as IFRS produzem efeito sobre o risco, busca atender aos interesses dos investidores do mercado de capitais, gestores de empresas, governo e agências reguladoras.

Em primeiro lugar, variáveis instrumentais, com base na informação contábil dos determinantes reais do risco sistêmico, são usadas para determinar os retornos anormais; dessa forma, a investigação que relaciona informações contábeis e seus reflexos no risco sistêmico proporciona, a investidores e gestores, uma visão ampliada para as estimativas e previsões de mercado, da mesma forma que favorece a formação de políticas contábeis.

A demonstração empírica da estabilidade de modelos de períodos de tempo diferentes e utilizando diferentes técnicas deve fornecer alguma garantia de que os dados baseados na Contabilidade fornecem proxies suficientes para os conceitos econômicos subjacentes. Os modelos também devem ser úteis a outros usuários das informações financeiras porque eles podem fornecer pistas a razões de modificações possíveis no risco.

Em outra ponta, esta tese buscou contribuir com a literatura existente fazendo uma revisão dos principais estudos sobre a relação da informação contábil com o risco e como o processo de adoção da IFRS pode afetar esta relação, além de colaborar com aqueles que unem as informações contábeis ao risco, estimulando pesquisas que estudem essa relação.

Assim, embora este estudo não tenha como proposta resolver o debate sobre os benefícios proporcionados pela adoção da IFRS, se almeja que ele acrescente algo ao mosaico das pesquisas sobre os efeitos dessa adoção. Desta forma, esta pesquisa propõe as seguintes contribuições para a literatura contábil:

\footnotetext{
${ }^{1}$ AAA - American Accounting Association. Committee to Prepare Statement of Basic Accounting Theory. A Statement of Basic Accounting Theory (ASOBAT). Evanston, I11.: AAA.
} 
a) As discussões sobre as consequências econômicas da aplicação das IFRS ganham um diferencial, pois componentes essenciais da tomada de decisão do investidor, que seria o risco e o retorno, passam a integrar os estudos acerca dos efeitos da adoção na qualidade da informação contábil, e muito já tendo sido debatido sobre o retorno, falta reflexões de como o risco responde a tantas mudanças.

b) Para que haja uma visão equilibrada do efeito de se adotar as IFRS e sua contribuição ao processo de comunicação, não se deve olhar somente a visão de quem elabora a informação (o contador), mas também a ótica de quem recebe a informação (o investidor), dado que a informação contábil interfere no seu processo decisório, por isso, nesta pesquisa, se intenciona realizar inferências a respeito das possíveis reações do investidor quando o nível de risco se altera. Deste modo, poder-se-ia realizar inferências mais fortes sobre as consequências de se adotar a IFRS.

c) A pesquisa intenciona também conjecturar para os reguladores se os seus objetivos têm sido concretizados, dado que tem sido elaboradas normas que buscam informação contábil de maior qualidade, então é deveras necessário verificar se essa maior qualidade, ao ser de fato alcançada, muda as expectativas do investidor em relação ao risco.

É importante destacar que não é a finalidade desta pesquisa, criticar ou reverenciar o regulador e o novo padrão contábil vigente, mas estabelecer apontamentos que permitam que toda a comunidade possa ter uma maior amplitude de visualizações a respeito do alcance econômico que tem tomado o processo de convergência internacional de padrões contábeis.

\subsection{Estruturação da Tese}

Além do capítulo da introdução, organizou-se a tese em mais quatro capítulos: explorando-se a base teórica que fundamenta essa pesquisa, a metodologia que lhe deu subisidio, os resultados alcançados e as considerações finais a cerca do estudo como um todo. 


\section{REVISÃO DA LITERATURA}

\subsection{O Mercado Eficiente e a Influência das Informações Contábeis}

Os estudos de conteúdo informacional das demonstrações contábeis para o mercado de capitais têm como base a hipótese de mercado eficiente (HME), a qual tem, como preceito base, que os preços das ações refletem toda e qualquer informação relevante disponível. A HME começou a ser estudada em 1970 e embora sofra algumas críticas no sentido de se considerar seus pressupostos com pouca aplicabilidade, no geral tem sido considerada a melhor forma de se estudar e entender as formações de preço no mercado de capitais.

Para Fama (1970), um mercado de capitais eficiente é aquele em que os preços fornecem sinais precisos para a alocação de recursos, isto é, um mercado no qual as empresas podem tomar decisões de investimento e os investidores podem escolher entre os títulos que representam a propriedade dessas empresas sob o pressuposto de que os preços dos ativos refletirão, a qualquer momento, todas as informações relevantes disponíveis.

Os pressupostos do mercado eficiente destacam que as condições de equilíbrio de mercado podem ser expressas em termos de retornos esperados e que estes são formados com base no conjunto de informações, refletindo-o plenamente. Nessa ótica, não seria possível vencer o mercado e obter retornos excessivos a partir dele, uma vez que não existiria a possibilidade de o investidor influenciar no preço da transação, já que este será o resultado do conjunto de informações disponíveis.

Logo, sugere-se que nenhuma informação, seja ela associada a preços passados ou a notícias públicas, poderia trazer vantagens a determinados investidores, em função de que as notícias, à medida que surgem, são refletidas de forma imediata no preço dos ativos. Isso ocorre em função das seguintes condições: a) o número de agentes maximizadores de utilidade, além de representar uma grande quantidade, opera no mercado de forma independente; b) os agentes econômicos ajustam rapidamente suas ofertas, de modo que elas possam refletir as novas informações sobre os ativos relacionados; c) as novas informações chegam ao mercado de forma aleatória e são independentes de outros conjuntos de informações disponíveis.

Fama (1970) propõe três formas de eficiência de mercado, considerando que o mercado seria mais ou menos eficiente em razão da reação à informação, representando uma espécie de relaxamento da HME. Embora não fosse a única, existia o entendimento, por parte do autor, que a Contabilidade é uma das fontes de informação. 
A eficiência do mercado em sua forma fraca determina que os subconjuntos de informações relevantes estão implícitos apenas no histórico de preços (ou retornos) passados (FAMA, 1970). Nesse caso, a forma fraca de eficiência é importante em termos de Contabilidade, pois acredita-se que o comportamento histórico dos preços das ações será utilizado para previsões de preços futuros, estando refletidas nos preços atuais de mercado. A forma fraca da HME não usa qualquer outra informação além do comportamento histórico dos preços, tais como lucros, previsões, anúncios ou dados de oferta, não se considerando sinais ou análise de tendências.

Na forma semiforte, a preocupação está no ajuste dos preços a outras informações relevantes que estão, obviamente, à disposição do público (por exemplo, anúncios de ganhos anuais, anúncios sobre distribuição de lucros e dividendos, desdobramentos, emissão de novas ações, demonstrações contábeis, notícias específicas etc) (FAMA, 1970). Assim, os preços refletem não só o seu comportamento passado, como também o restante da informação publicada, se ajustando a qualquer notícia, boa ou ruim, no momento em que estas forem divulgadas, desde que sejam diferentes daquela esperada.

A eficiência forte trabalha com o pressuposto de que qualquer informação relevante, sendo conhecida por pelo menos um investidor, estará integralmente no preço da ação. Assim, os preços refletem não só a informação pública, mas toda a informação que pode ser obtida, inclusive de forma privilegiada. Sob essa forma, aqueles que adquirem a informação agem com base nela, fazendo com que o preço se ajuste rapidamente para refletir a informação privada. No entanto, Fama (1970) comenta que a forma forte não possui muita aplicabilidade entre os economistas, sendo que os debates estão mais concentrados entre as formas fracas e semiforte, dada a aplicabilidade.

Segundo Fama (1970), algumas condições do mercado podem ajudar ou dificultar na compreensão do ajuste eficiente dos preços, tais quais: a) não existem custos de transação em títulos para negociação; b) todas as informações estão disponíveis gratuitamente para todos os participantes do mercado e c) que todos estão de acordo com as implicações das informações atuais sobre o preço atual e distribuições futuras de cada título. Sendo possível dizer que essa seria uma espécie de conceito limite, ou seja, os mercados tendem a ser assim, mas não são exatamente assim na prática.

A eficiência dos preços do mercado de ações em relação a todas as informações publicamente disponíveis ("eficiência do mercado") descreve um resultado que é desejável na medida em que facilita a alocação eficiente de recursos de capital de risco e na sociedade. 
Assim, a informação dita relevante seria aquela que pudesse influenciar a formação dos fluxos futuros de caixa e, consequentemente, na expectativa dos investidores. De acordo com os pressupostos da HME haveria, no mercado, os investidores racionais que, utilizando-se de análises técnicas e fundamentalistas, avaliariam cada título pelo seu valor intrínseco, ou seja, pelo valor atualizado de um fluxo de caixa futuro, descontado pela taxa de juros que contempla as características do risco envolvido na negociação.

À medida que novas informações são disponibilizadas ao mercado, ele responde alterando os preços que aumentam quando se trata de boas notícias e diminuem quando as notícias não são boas. Assim, a HME preconiza que os preços dos ativos refletem plenamente as informações disponíveis e a velocidade de ajustamento é muito rápida. Desta forma, os preços surtirão o efeito das informações antecipadas.

A hipótese do mercado eficiente testada por Fama (1970) tem sido bastante aceita pelas comprovações empíricas realizadas, no entanto, deve-se considerar que seus pressupostos recebem algumas críticas, considerando o fato de que algumas indicações contrárias têm sido incapazes de ser ignoradas.

É certo que, mesmo ressaltando-se a racionalidade do investidor, visualiza-se que a decisão é tomada com base em circunstâncias específicas do tomador. De fato, no momento em que os investidores tomam posse de novas informações, suas crenças e preferências são analisadas e decisões consistentes são tomadas de acordo com a utilidade esperada, que interagem, neste momento, com as suas expectativas, com a conexão entre os ativos e com a aversão ao risco.

No entanto, trabalhos como o de Jensen (1978) enfatizam que não existe evidência empírica mais sólida do que a que apoia a HME e destaca que as evidências encontradas quando se buscava inconsistências com a HME podem ser tratadas de comprovações econométricas limitadas à época da realização dos principais testes.

Segundo Jensen (1978), a HME, em essência, é uma condição preliminar para o equilíbrio do mercado. Porém, é válido ressaltar que "relaxamentos" na hipótese devem ser previstos, no sentido de garantir o melhor entendimento do processo de tomada de decisão do investidor, haja vista que também existem evidências da presença das anomalias, o que, de fato, provoca impropriedade no conhecimento de como a hipótese foi montada.

A operacionalização desta perspectiva dentro de um contexto econômico, considera a ideia "da racionalidade limitada", sugerindo que os indivíduos sejam capazes de otimizar recursos segundo a utilidade esperada, que prevê escolhas simplesmente satisfatórias, e não necessariamente ótimas. 
A informação até aqui remetida refere-se a qualquer informação pública ou privada a respeito de uma ação. A informação pública seria aquela disponível a todos os investidores e a informação privada seria aquela ainda não divulgada ao público em geral, mas que pode fazer parte do processo decisório de um ou outro investidor, sendo importante ressaltar que esta última pode representar prática ilícita, pois, nos preceitos da eficiência de mercado buscam-se informações simétricas, de modo que todas elas sejam acessíveis a todos os investidores (FAMA, 1991; COHEN; MALLOY; POMORSKI, 2012). A assimetria informacional seria então um problema enfrentado pelo mercado, já que alguns investidores podem ter acesso a mais informações do que outros (AKERLOF, 1970).

O fornecimento de informações tem sido destacado no mercado, inclusive como uma forma de evitar a seleção adversa, que é um fenômeno onde se parte da impossibilidade de que o investidor conheça todos os riscos da transação, considerando a existência de assimetria informacional, o que é interpretado negativamente, uma vez que, quando alguma informação não é publicada, os participantes do mercado subentendem estar como negativa, assim, esse caráter negativo é diminuído pelo acesso à informação (AKERLOF, 1970; SALOTTI; YAMAMOTO, 2005).

Akerlof (1970) defende que a assimetria informacional pode impossibilitar que haja bons produtos no mercado, pois se só poucos têm acesso à informação acerca de quais são os produtos de boa qualidade e estes, por sua vez, segurassem sua venda por não aceitarem o preço médio que está sendo oferecido no mercado, muito provavelmente não haveria bons produtos à venda. Dessa forma, a maior disponibilidade de informações direciona para uma maior qualidade do produto e, principalmente, uma melhor aceitação dele diante dos seus consumidores.

Nessa ideia, pode-se dizer que a falta de informação impulsiona o mercado a nivelar as companhias, em razão de que informações de baixa qualidade são colocadas no mesmo patamar que aquelas que apresentam boa qualidade. Nesse caso, a assimetria informacional é vista como uma medida que sinaliza a qualidade da informação, de modo que sua existência implica que as informações públicas não são de boa qualidade, não permitindo tomada de decisões seguras.

A disponibilidade de informações contábeis das empresas pode, então, mitigar o problema de seleção adversa e aumentar a liquidez do mercado, nivelando o campo de jogo entre os investidores, considerando que a liquidez do mercado trabalha a celeridade das transações, de forma a ampliar o campo de ação do investidor (VERRECCHIA, 2001).

Do exposto, percebe-se que a informação contábil tem sido ferramenta indispensável para a segurança do investidor, auxiliando-o a determinar qual o melhor investimento a ser 
realizado para que haja o retorno do capital investido. Para Machado, Silva Filho e Calado (2014), a informação contábil, a partir da predição de fluxos de caixa futuros, é relevante para o mercado de capitais, sendo essencial na precificação de ativos. Dessa forma, sendo consideradas relevantes, na visão de Barth, Beaver e Landsman (2001), as informações contábeis são refletidas nos preços, sendo capazes de fazer a diferença para o processo decisório dos usuários.

Apesar das críticas no sentido de uma possível ineficiência de mercado, a HME descreve um equilíbrio de preços do mercado de capitais, já as teorias comportamentais sobre ineficiência do mercado descrevem preços transitórios, ou seja, estados que não devem persistir em perfeitas condições de mercado (KOTHARI, RAMANNA, SKINNER, 2010).

Dessa forma, se as normas contábeis fossem projetadas assumindo ineficiência do mercado, não ficaria claro como tal norma levaria a um estado de equilíbrio rumo à eficiência do mercado. Sem uma estrutura para compreender a origem e a persistência de preços irracionais, surgem várias questões importantes: Será que a ineficiência persistiria, não importando o design das normas? Ou pior, pode a ineficiência ser exageradamente mal compreendida e, assim, mal regulada? (KOTHARI, RAMANNA, SKINNER, 2010).

Assim, mesmo que os investidores estivessem a apresentar vieses comportamentais, argumenta-se que as normas contábeis deveriam ser concebidas como se o preço de mercado fosse eficiente, ou seja, de acordo com a racionalidade dos investidores, e os preços, em média, refletindo os fundamentos econômicos (KOTHARI, RAMANNA, SKINNER, 2010).

As informações contábeis exercem papel de considerável importância na decisão do investidor, uma vez que a divulgação de relatórios contábeis possui conteúdo informacional, sendo capazes de auxiliar na tomada de decisão e, assim, consequentemente, exercer impacto na formação do preço dos ativos (BALL; BROWN, 1968; BEAVER, 1968). Portanto, as informações disponibilizadas pelas firmas, por meio de seus relatórios financeiros, tendem a afetar o preço dos títulos.

Watts e Zimmerman (1986) enfatizam que o lucro contábil fornece informação sobre os fluxos de caixa correntes e esperados, onde estes, por sua vez, são ferramentas indispensáveis para se conhecer o valor da empresa, portanto, para a tomada de decisão de investimentos. Além disso, a informação do lucro contábil é tida como uma das principais medidas de desempenho da firma e tem forte conteúdo informacional.

Alguns estudos buscaram verificar a temporalidade da resposta proporcionada pela informação do lucro, ou seja, se o lucro contábil realmente é tempestivo em termos de conteúdo informacional, considerando sua participação na formação do preço das ações, encontrando 
evidências de que a informação contábil faz parte das informações responsáveis pela formação do preço (BEAVER; LAMBERT; MORSE, 1980; LEV, 1989; COLLINS et al., 1994; BASU, 1997; KALLUNKI et al., 1997; KOTHARI, 2001).

Beaver, Lambert e Ryan (1987) utilizaram a técnica de regressão reversa, assumindo que esta é mais intuitiva e mais eficiente para avaliar o poder explanatório incremental dos valores defasados de alterações percentuais no preço, em relação ao lucro contábil. Os autores identificaram que os valores defasados mais imediatos foram estatisticamente significantes, o que sustenta a hipótese de que o lucro contábil tem conteúdo informacional na formação do preço. Outros autores, como Collins et al. (1994), também identificaram resultados semelhantes, mesmo utilizando-se de uma modelagem um pouco distinta.

Watts e Zimmerman (1986) destacam que a informação contábil pode ser vista como um bem público. Em vista disso, acionistas pagam implicitamente para sua produção, mas não podem cobrar, de potenciais investidores, o uso da informação. Os potenciais investidores, portanto, pegam carona na informação que foi paga pelos acionistas e, por consequência, a informação beneficia não somente a quem produziu, mas também a todos que dela fizerem uso, de forma que os benefícios proporcionados pela informação disponibilizada são ampliados consideravelmente.

Verrecchia (2001) estudou como a divulgação da informação afeta os preços e se reflete nos investidores. Existe uma preocupação em verificar como a divulgação está associada à competitividade dos investidores e como ela os auxilia a maximizar suas riquezas individuais. Assim, considera-se que uma informação contábil relevante tende a ser incorporada aos preços dos títulos de forma rápida e imediata. O mercado vai absorver e precificar rapidamente a informação.

Também deve ser observado que, quando se fala em informações contábeis, o usuário é peça fundamental, de modo que, para influenciar a sua tomada de decisão, ele também deve estar aberto ao processo de compreensão e de interpretação desta; assim, a utilidade da informação contábil não está atrelada a um conceito, mas ao enquadramento de uma boa relação entre emissor e receptor da informação, aproximando, assim, a Contabilidade do processo decisório.

É certo que o investidor busca a participação no lucro a partir do acesso à informação. Assim, direcionados por oportunidades de lucro, esses investidores buscam até as mínimas vantagens informacionais à sua disposição e, nesse sentido, a Contabilidade tem auxiliado consideravelmente nessa missão. 
Leuz e Wysocki (2008) focam que a discussão sobre o fornecimento de informações contábeis foi afervorada a partir de crises e/ou acontecimentos que colocaram em cheque a fidedignidade da informação, através dos quais investidores preocupados com o retorno dos seus investimentos passaram a requerer o aumento da transparência corporativa, aumento do controle com relação à qualidade da informação e até mesmo exigindo a promulgação de alterações significativas na regulação contábil.

Hope (2002) destaca que a informação contábil também foi apontada como detentora de uma relação positiva com a acurácia da previsão de ganhos dos analistas, reduzindo a incerteza a respeito das escolhas dos gestores.

Bruggemann, Hitz e Sellhorn (2013) enfocam que, dentro do papel da informação contábil, está sua contribuição aos investidores em permitir que se apresentem previsões mais acuradas de futuros dividendos, potencialmente afetando os valores das firmas e influindo no conjunto de investidores atuais e potenciais.

Healy e Palepu (2001) defendem que a disponibilização de informações contábeis minimiza a má alocação de recursos dentro do mercado de capitais, considerando que aumenta a probabilidade de o investidor de aplicar seus recursos corretamente. Além disso, disponibilizar as informações contábeis aumenta a credibilidade da firma.

DeFond, Hung e Trezevant (2007) destacam que os investidores respondem aos anúncios dos lucros e essa reação é mais forte quando a qualidade da informação contábil é mais alta, por tornar a informação mais confiável.

Dechow, Ge e Schrand (2010) destacam que a alta qualidade da informação contábil fornece mais informação sobre as características do desempenho de uma firma, o que será relevante para uma decisão individual tomada por um responsável específico.

Soderstrom e Sun (2007) enfatizam que um ambiente contábil mais transparente facilita inclusive a atividade de compra e fusão de empresas, pois quando essas firmas adotam padrões contábeis mais transparentes, facilita-se a negociação, aumentando a probabilidade de efetivar a transação.

A informação contábil, de maior qualidade, captura melhor a realização econômica subjacente de uma firma, em razão da maior utilidade para os investidores quando da avaliação dela (DEFOND; HUNG; TREZEVANT, 2007).

Para Scott (2007), a informação tem sido percebida pelo mercado como útil. Frankel e Li (2004) reforça à importância das informações contábeis, destacando que elas são uma fonte de informação importante para os usuários, desde a promoção da comunicação entre os usuários 
internos e externos, até o funcionamento do mercado de capitais como um todo, de maneira que uma informação contábil robusta e de alta qualidade torna o mercado de capital mais eficaz.

Os próprios órgãos responsáveis pela regulação da informação contábil têm se preocupado com a sua utilidade. A IFRSFoundation (2014) determina que a prática contábil seja fundamentada em normas de alta qualidade. Frankel e Li (2004) destacam que a informação contábil de qualidade deve ser justa e relevante, frisando que todos os investidores devem ter acesso a esta informação. Enfatiza-se que a redução da assimetria informacional fortalece o mercado de capitais, tornando os mercados mais eficientes e transparentes.

Uma informação contábil de qualidade seria aquela que tivesse um maior controle sobre o gerenciamento dos resultados (DEFOND; HUNG; TREZEVANT, 2007). A comparabilidade também é tomada como uma qualidade da informação contábil, permitindo aos usuários identificar semelhanças e diferenças entre dois conjuntos de fenômenos econômicos. Dessa forma, deve-se destacar que comparabilidade e uniformidade são duas coisas diferentes, onde a uniformidade já enfatiza a necessidade de exigir que todas as entidades usem os mesmos métodos contábeis, não permitindo a flexibilidade. No caso, destaca-se que a falta de uniformidade não necessariamente inibe a comparabilidade, a qual é explorada mesmo ao se considerar condições específicas de cada empresa, pois a Contabilidade trabalha com representações (ZEFF, 2007).

O conservadorismo também foi tomado como um atributo de qualidade, de modo que lucros que refletissem mais oportunamente as perdas seriam consideradas como de maior qualidade. Outro atributo é a relevância (value-relevance), que diz respeito a uma associação maior entre a informação do lucro e aos preços das ações (BARTH; LANDSMAN; LANG, 2008). Kargin (2013) coloca que o value-relevance pode ser definido como a capacidade da informação de apresentar informações financeiras que capturem e resumam o valor justo, onde de fato contribuam para uma boa escolha no processo decisório.

Um destaque da pesquisa de Barth, Landsman e Lang (2008) foi trabalhar com métricas de qualidade que refletem o efeito dos relatórios financeiros no ambiente econômico, com destaque à utilização da volatidade como proxy para o ambiente econômico. Desse modo, buscou-se identificar se as mudanças no ambiente econômico modificam a qualidade da informação.

Armstrong et al. (2010) ressaltam, então, que a informação contábil de qualidade é aquela que tem uma melhor transparência financeira, menor assimetria informacional, ao ponto de diminuir o risco do investidor e o custo de capital. 
A disponibilização da informação contábil pela firma é remunerada pelo mercado, pois aumenta os níveis de transparência e comparabilidade, do mesmo modo que diminui a assimetria informacional e a seleção adversa, apresentando maiores revelações a respeito da situação da empresa, diminuindo a incerteza por parte dos investidores e fazendo com que exista a possibilidade de redução do risco sistêmico (BOTOSAN, 1997).

Se a disponibilidade da informação contábil de uma determinada empresa for baixa, haverá dificuldade de avaliação para o acompanhamento das atividades desta, fazendo com que investidores sejam mais restritivos em investir seus recursos, passando a exigir uma maior compensação para assumir o risco em questão, consequentemente, o custo de capital dessa empresa será maior.

Barth (2008) destaca que uma informação de qualidade necessita de confiabilidade, materialidade e neutralidade e que represente fielmente - ou razoavelmente - aquilo que seja esperado representar. A verificabilidade também é apontada como uma qualidade da informação, mas já seria utilizada como uma forma de realçar a informação relevante e com fidedignidade de representação.

Soderstrom e Sun (2007) enfatizam, ainda, que os padrões contábeis, os sistemas legais e políticos e estímulos de relatórios contábeis são também determinantes para a qualidade da informação contábil.

No geral, pode ser observado que a informação contábil é considerada como útil para a tomada de decisão do investidor, fazendo com que este possa ter uma visão diferenciada com relação ao valor da firma, de modo a lhe permitir a formulação de diversos cenários de decisão. Cada cenário decisório trabalhará com expectativas de risco e retorno diferenciadas, de forma que, quanto maior a qualidade da informação contábil, mais alternativas de decisão são direcionadas no sentido do equilíbrio entre o risco e o retorno.

Assim, cada atributo presente na qualidade da informação culmina em uma peça na construção do melhor equilíbrio risco e retorno e, como em um efeito dominó, a presença e intensidade de cada atributo vai culminando em uma informação contábil mais robusta e que poderá afetar as expectativas do investidor diante do equilíbrio risco e retorno.

\subsection{Convergência Internacional das Práticas Contábeis}

A harmonização de padrões contábeis tem sido um tema bastante discutido em termos globais entre os profissionais da área. O processo de harmonização contábil busca normas de 
práticas e políticas contábeis por meio de um código ou padrão único (SHIL; DAS; PRAMANIK, 2009).

A harmonização das práticas contábeis é uma decorrência da materialização das mudanças globais em termos econômicos, pois as divergências entre essas práticas nos diferentes países já não permitiam uma celeridade e confiabilidade nas transações comerciais entre firmas e investidores de nacionalidades diferentes. Passa, então, a ser essencial que haja a criação de padrões contábeis de abrangência internacional.

Dessa forma, o crescimento rápido do comércio internacional e a internacionalização de firmas, tanto quanto o desenvolvimento de novas tecnologias de comunicação, e a emergência de forças competitivas internacionais estão constantemente perturbando o ambiente financeiro, de forma que sempre buscam respaldo da Contabilidade para que seja possível uma interação entre os diversos usuários da informação contábil (SHIL; DAS; PRAMANIK, 2009).

Logo após a segunda guerra mundial, vivenciou-se um período de rápido crescimento no comércio internacional e no conjunto de investimentos; neste contexto, deve-se considerar que os países vencedores aproveitaram o momento para promover excelentes transações comerciais nos países perdedores, principalmente intensificando o capital através dos empréstimos de recursos. Estima-se que, entre 1950 e 1965, o valor do movimento do capital externo cresceu consideravelmente. Houve uma ação crescente do fluxo de capital estrangeiro, compondo-se da injeção direta de investimentos que, por sua vez, esteve fortemente relacionado à ascensão das corporações multinacionais (CAMFFERMAN; ZEFF, 2007).

Os anos 60 foram marcados por fusões internacionais frequentes e aquisições de corporações de um país por companhias de outros países e, assim, as companhias domésticas começaram a redobrar internacionalmente as suas operações de produção, bem como a sua equipe de gerência. Discussões focadas e especiais começavam a ser dadas em termos de uma nova forma de organização de negócios, o que se chamava "companhias multinacionais". Portanto, de fato, essa é uma tendência internacionalista, que aumenta, consideravelmente, o desejo ou a necessidade de comparar informações contábeis preparadas em países diferentes (ZEFF, 2012).

Foi dentro desse contexto, que se viu a necessidade de cada país ter os seus princípios contábeis próprios ou prática contábil própria. Tais princípios, ditos GAAPs (Generally Accepted Accounting Principles) em países anglo-americanos e em países do continente Europeu e no Japão, foram bastante guiados por ordem da tributação do resultado, que acabou conduzindo a prática contábil. Em 1947, a França estabeleceu o Plano Contábil Nacional, uma regulação detalhada, a Contabilidade da companhia estava devidamente codificada. Outros 
exemplos poderiam ser encontrados na Bélgica, na Espanha, em Portugal, no Marrocos, na Tunísia, na Argélia e no Peru. No geral, a prática contábil no mundo inteiro foi se mostrando altamente divergente e a comparação de informações contábeis entre os países tornou-se muito difícil (ZEFF, 2012).

É possível visualizar que de país para país as práticas contábeis se apresentavam divergentes e, de fato, ao se falar de uma multinacional, pode se encontrar casos que o resultado da mesma empresa seja diferente a depender das práticas contábeis vigentes nos países em que opera. Isso se deve ao fato de que as práticas contábeis de cada país, vistas isoladamente, dependem de um conjunto de fatores de ordem legal, econômica, cultural, ambiental etc.

Dentro desse contexto, a necessidade de uma Contabilidade baseada em princípios comuns se torna imensamente óbvia, já que é extremamente difícil, e em muitos casos impossível, realizar-se comparações justas entre companhias de países diferentes (EBIMOBOWEI, 2012). A preocupação com a "Contabilidade Internacional" passava a se fazer presente diante dos profissionais contábeis, em razão da dificuldade de se trabalhar uma informação de qualidade sob tantas roupagens diferenciadas.

A harmonização passou, então, a ser visualizada como solução para reduzir os conflitos contábeis existentes entre os países, o que desembocou na uniformização das demonstrações contábeis, assegurando a coerência e a comparabilidade dos dados divulgados pelas empresas. Nesse sentido, a intenção maior é, então, que as informações contábeis sejam projetadas e prescritas para melhorar o nível da qualidade das demonstrações. Seriam, portanto, analogamente, a mobília para que possa haver um acesso à informação útil por parte de usuários diferentes, como acionistas, credores, financiadores, gerência, investidores, fornecedores, concorrentes, pesquisadores, corpos reguladores e sociedade em geral (SHIL; DAS; PRAMANIK, 2009).

O contexto social e econômico globalizado, baseado na internacionalização de atividades econômicas e na integração de mercados de capitais, determinou uma transformação gradual nas demonstrações contábeis ao redor do mundo. A necessidade de preparar informação financeira confiável e comparável, não só dentro de um dado país, mas também na esfera internacional, estimulou um processo de harmonização contábil global que levou a uma modificação dos modelos de regulação nacionais (ARGENTO, 2008).

Segundo Shil, Das e Pramanik (2009), o processo da harmonização de práticas contábeis confere uma natureza de entidade única à comunidade global. Logo, a expansão enfrentada pelos mercados de capitais internacionais e, como consequência, a crescente necessidade de 
comunicação global imediata trouxe, para a Contabilidade, a carga de fornecer informação útil e comparável em âmbito internacional.

A adoção de padrões contábeis de ordem internacional remete a benefícios econômicos concretos, uma vez que a globalização econômica traz consigo a demanda por informações contábeis comparáveis e que sejam acreditadas em qualquer lugar do mundo, dando, portanto, validade à diversidade de transações surgidas dentro de um mercado global.

A "harmonização" de padrões contábeis ajudaria a economia mundial ao proporcionar uma melhor visualização da realidade dos mercados financeiros, minimizando o custo da troca de informação, assim como proporcionando o fornecimento de informações mais fidedignas. (SHIL; DAS; PRAMANIK, 2009; AL-OMARI, 2010).

Um sistema de padrões globais de informações contábeis é um pré-requisito para atrair investidores estrangeiros, de modo que possibilitará uma maior confiança nas informações prestadas pela Contabilidade. Nesse sentido, com a ausência da harmonização o "preço adicional" requerido pelas demonstrações contábeis, junto com outras dificuldades que os grupos multinacionais enfrentam na maneira com a qual eles empreendem as transações, se torna crítico, sendo praticamente impossível consolidar informações contábeis nesse tipo de firma (SHIL; DAS; PRAMANIK, 2009; AL-OMARI, 2010).

Al-Omari (2010) acrescenta que as vantagens da harmonização incluem: o potencial de melhora rápida no mercado local da qualidade das demonstrações contábeis; uma redução ou a eliminação completa dos custos de desenvolvimento de padrões contábeis nacionais; aumentos na eficiência em mercados financeiros nacionais e internacionais pelo fornecimento de informações contábeis mais compreensíveis, confiáveis e comparáveis.

Uma harmonização das práticas e políticas contábeis poderá fornecer um campo de atuação de nível global para a Contabilidade, fornecendo, aos usuários, uma identidade única, não se constituindo um fim em si mesmo, mas um meio que direciona a um fim. A adoção de padrões contábeis diferentes causa dificuldades na realização de avaliação das empresas e, consequentemente, impede o processo de tomada de decisão eficaz (SHIL; DAS; PRAMANIK, 2009).

No entanto, não se pode deixar de considerar que a desvantagem da harmonização remete ao desenvolvimento de padrões comuns a países em que são inaplicáveis às necessidades nacionais, podendo haver uma sobrecarga de padrões. Mas todos os governos e os órgãos reguladores devem tentar equilibrar as vantagens relativas e desvantagens experimentadas para tomar a decisão correta ou, em outras palavras, avaliar a relevância de padrões internacionais às necessidades nacionais (AL-OMARI, 2010). 
Diante desse contexto, algumas organizações internacionais começaram a trabalhar para reduzir as diferenças em padrões contábeis entre as nações e tentando eliminar todas as diferenças necessárias, dando início, portanto, ao processo de convergência internacional (SHIL; DAS; PRAMANIK, 2009).

O fato é que a noção da harmonização foi substituída pelo conceito de convergência, que seria o processo de desenvolvimento de um conjunto unificado de padrões contábeis internacionais de alta qualidade, os quais seriam tão semelhantes quanto possível e que seriam usados em pelo menos todos os principais mercados de capitais. A ideia de convergência foi, então, uma evolução, demonstrando maior adequação à realidade enfrentada (ZEFF, 2007; FASB, 2014a).

A imagem da convergência, embora mais próxima da utilização de princípios contábeis, que retiravam o sentido da obrigatoriedade de regras e passava a aproximar as similaridades para construir padrões contábeis, se enquadravam mais propriamente à ideia de padronização, na qual a proposta caminha rumo a proporcionar a comparabilidade. Assim, o processo de unificação se tornava mais crível.

Mesmo que em alguns momentos a harmonização tenha sido associada erradamente com a padronização, elas são bastante diferentes. A harmonização está na essência e conserva um alto grau de flexibilidade às práticas contábeis, ao passo que a padronização se refere à eliminação da possibilidade de diversas alternativas para a prestação de contas das transações econômicas e outros eventos (AL-OMARI, 2010).

Os investidores, as companhias, os auditores e outros participantes do sistema das demonstrações contábeis beneficiam-se do aumento da comparabilidade que resultaria, internacionalmente, da convergência de padrões que se referem tanto a um objetivo, quanto ao caminho tomado para consegui-lo (FASB, 2014b).

O que se espera do processo de convergência seria, portanto, o desenvolvimento de um conjunto unificado de padrões contábeis internacionais de alta qualidade, que as companhias no mundo inteiro usariam tanto para as demonstrações contábeis domésticas, quanto internacionais. É notoriamente reconhecido que o processo de convergência é necessário para a proteção de investidores, sendo de apropriado interesse público (FASB, 2014b).

Pode-se dizer que o conceito da convergência de padrões contábeis não é um conceito recente - surgiu no século XX, quando a ideia "de Padrões Contábeis Internacionais" foi germinada no primeiro Congresso Internacional de Contadores. Novamente, em 1957, durante o $7^{\circ}$ Congresso Internacional de Contadores, realizado em Amsterdam, o Sr. Jacobkraayenhof 
falou da necessidade de cooperação contábil internacional e da padronização de práticas contábeis (SHIL; DAS; PRAMANIK, 2009).

Quando presidente do American Institute of Certified Public Accountants (AICPA), LeRoy Layton, descreveu que houve um pensamento consistente expresso, segundo o qual grupos de estudos deveriam ser estabelecidos rapidamente, algo como que um corpo de peritos (um grupo de estudo ou um comitê internacional) que teria, em uma base de continuação, a difícil tarefa de estabelecer padrões internacionais de Contabilidade e de auditoria ou, no mínimo, trazer os padrões nacionais variados em uma proposta de acordo mais fechada (CAMFFERMAN; ZEFF, 2007).

As discussões e estudos a respeito de uma linguagem única para a Contabilidade começaram a se intensificar em outras partes do mundo, de forma que foram então sendo realizadas pesquisas de forma a identificar e comparar pensamentos e práticas contábeis entre os países envolvidos (SHIL; DAS; PRAMANIK, 2009).

Por conseguinte, com a convergência sendo de fato um processo extremamente necessário, o então presidente do Institute of Chartered Accountants in England and Wales (ICAEW), Senhor Henry Benson criou, em 1966, o "Accountants International Study Group" (AISG), incluindo representantes da profissão de Contabilidade no Reino Unido, nos Estados Unidos e no Canadá. O Grupo de Estudo produziu 20 livros, que fomentavam uma comparação da informação em várias práticas contábeis adotadas nos três países, sendo um grupo de destaque, que favoreceu a cooperação entre a Contabilidade de três nações diferentes, abrindo o caminho para a criação de um diálogo a respeito de padrões contábeis internacionais. Porém, as publicações do grupo de estudo nunca foram destinadas a padronizar o comportamento de ninguém, daí o passo lógico seguinte foi o de formar um órgão que possuísse maior autoridade para deliberar acerca da melhor prática contábil ao redor do mundo (CAMFFERMAN; ZEFF, 2007).

Benson, tido como o precursor de um movimento responsável por atacar as questões de práticas contábeis divergentes, enfrentou a criação de um grupo semelhante, que buscou o estabelecimento de padrões em nível internacional, inclusive com uma mais larga tabela de países do que a prevista no grupo de estudo. No entanto, o grupo se propunha a condução de um órgão de Contabilidade, de forma que em invés de realizar publicações de livros de estudo, a nova proposta teria o intuito de firmar compromisso para a formulação de padrões contábeis internacionais e assegurar a sua aceitação mundial (CAMFFERMAN; ZEFF, 2007).

Benson destacou que não houve nenhuma dificuldade em se chegar a um acordo sobre a necessidade de se criar padrões contábeis internacionais, com a finalidade de dirimir as 
divergências encontradas de país para país. Embora houvesse ainda muitas divergências de opinião acerca dos planos práticos, no sentido de se estabelecer qual a melhor forma de se alcançar o objetivo traçado, todos os países engajados na proposta sentiram que a ideia de implantar padrões contábeis internacionais já estava madura e, portanto, a proposta de um órgão que representasse esses anseios se tornava inadiável (CAMFFERMAN; ZEFF, 2007).

Em princípio, todos aceitaram a ideia da existência de um padrão único de Contabilidade. Mas passou a existir dificuldades, quando da definição de tais padrões, em que cada país, particularmente, defende que "seu" padrão é o mais adequado; assim, a existência de um órgão que pudesse fazer a intermediação, organizar e estudar as mais diversas propostas se fazia essencial.

Os conselhos dos institutos que participaram do grupo de estudos definiram uma proposta concreta em 1972, indicando, portanto, a criação do novo órgão, chamando de International Accounting Standards Committee (IASC) (CAMFFERMAN; ZEFF, 2007). No Congresso Internacional de Contadores em Sidney, em 1972, o International Coordination Committee for Accounting Profession (ICCAP) foi o passo seguinte, tendo sido formado para instituir a base do estabelecimento de uma organização formal de Padrões Contábeis Internacionais, surgindo, daí o IASC no ano de 1973 (CAMFFERMAN; ZEFF, 2007; SHIL; DAS; PRAMANIK, 2009).

Assim, o IASC nasceu em consequência de um acordo feito por órgãos normatizadores da Contabilidade, representantes de nove nações - Canadá, Austrália, França, Japão, Alemanha, México, países Baixos, Reino Unido e os Estados Unidos de América - tendo sua sede em Londres (CAMFFERMAN; ZEFF, 2007).

A formação do IASC foi a resposta mais importante, organizada e durável da profissão contábil ao crescimento da internacionalização do mercado de capitais depois da segunda guerra mundial (CAMFFERMAN; ZEFF, 2007). Depois de quase 25 anos de sua realização, o IASC concluiu, em 1997, que, para continuar executando o seu papel efetivamente, deveria encontrar um modo de promover a convergência entre padrões contábeis nacionais, primando por padrões de alta qualidade, visualizando a necessidade de modificar a sua estrutura (IASPLUS, 2014a).

Isto posto, entre 1999-2000, o IASC reestruturou-se, passando a ser chamado de International Accounting Standards Board (IASB), onde a principal mudança residiu no fato de que o órgão contaria com a maior parte dos membros com dedicação exclusiva, além de um corpo de colaboradores consideravelmente maior. O IASB garantiu o reconhecimento internacional e aceitação que o IASC havia logrado, e, hoje, ele estabelece padrões de 
demonstrações contábeis internacionais das empresas do setor privado ao redor do mundo (CAMFFERMAN; ZEFF, 2007).

A criação do IASB tem sido uma iniciativa de sucesso, respeitada e que efetivamente dá suporte aos órgãos nacionais de Contabilidade e aos reguladores nos principais mercados de capitais, bem como aos elaboradores e usuários das informações contábeis ao redor do mundo. O IASB tornou-se uma espécie de cão de caça de padrões contábeis de qualidade e tem se destacado por ter tido êxito nessa função. Dessa forma, com competência, o IASB passou a ser aceito e encarado com seriedade pelos países ao redor do mundo (ZEFF, 2012).

Destarte, o IASB foi demonstrando cumprir seu papel de redução das diferenças internacionais entre as práticas contábeis ao primar pela melhoria da qualidade e alcance da comparabilidade das demonstrações contábeis das companhias mundiais.

O IASB é, então, um órgão independente, que desenvolve e aprova padrões de demonstrações contábeis internacionais, as IFRS. O IASB tem a responsabilidade completa por todas as matérias técnicas da IASCF (International Accounting Standards Committee Foundation) (IFRS FOUNDATION) (IASPLUS, 2014b).

A IASCF é a fundação do comitê de normas Contábeis internacionais, sendo uma entidade legal que funciona abaixo do IASB e que tem como objetivos: desenvolver o interesse público para um conjunto único de padrões contábeis globalmente aceitos, desenvolvidos pelo IASB e constituídos sobre princípios claramente articulados e de alta qualidade, ajudando investidores, outros participantes do mercado de capitais e outros usuários da informação contábil a tomarem decisões econômicas. Deve também promover o uso e a aplicação rigorosa desses padrões, de forma que deve promover e facilitar a adoção da IFRS (IASPLUS, 2014c).

O trabalho da Fundação, na representação do IASB, tem se destacado por manter um processo de elaboração de normas sistemático, aberto, participativo e transparente, além de primar pela interação com investidores, reguladores, empresários e com a profissão contábil em geral, em cada estágio do processo (IFRSFOUNDATION, 2014).

Desde o ano de 2001, pode-se dizer que em torno de 138 países já estão requerendo ou permitindo o uso da IFRS (IFRSFOUNDATION, 2015), o que possibilita se dizer que o processo de convergência internacional de padrões contábeis parece estar conseguindo atender as pretensões para as quais foi criado (BARBU; BAKER, 2010).

Deve-se destacar que o processo de convergência internacional de padrões contábeis tem seu êxito subsidiado por pressões isomórficas, de modo que os países (representados por seus respectivos órgãos normatizadores de práticas contábeis) sentem a necessidade de seguirem o mesmo processo que os demais países estão seguindo, sob pena de serem excluídos 
de parte das transações comerciais. Assim sendo, o referido processo tem seu principal fundamento na busca da similaridade, posto que é notório que países que ainda não participam se sentem "coagidos" a tomar parte, já que o distanciamento pode ser entendido como sinônimo de normas contábeis de baixa qualidade (JERMAKOWICZ; GORNIK-TOMASZEWSKI, 2006; ZEGHAL; MHEDHBI, 2006).

As IFRS fornecem um melhor enquadramento das informações contábeis e princípios, com destaque para a comparabilidade e confiabilidade, resultando em maior segurança por parte dos investidores, nas informações que estão sendo utilizadas nos seus respectivos processos decisórios, sendo possível, inclusive, avaliar o risco da informação (ZEGHAL; MHEDHBI, 2006; AL-OMARI, 2010), pois, a partir do momento que o investidor acredita no aumento da credibilidade da informação divulgada, o risco dos papéis tende a ser diminuído.

Partindo do pressuposto de que a entidade afeta o meio e é por ele afetada, a decisão do país por participar do processo de convergência estabelece a garantia de que as instituições sob sua jurisdição, de fato, responderam à influência do meio, considerando que sua continuidade só estaria garantida se ela pudesse proporcionar a cobertura do processo de comunicação com seus usuários, não só em nível doméstico, mas no âmbito internacional, com um conjunto maior de informações que aumentaria a transparência, consequentemente, provocaria uma menor assimetria informacional entre os usuários; e o despertar de uma consciência recíproca que todos os participantes do processo têm quanto a um objetivo comum que é melhorar a qualidade da informação contábil e promover a comparabilidade (SHIL; DAS; PRAMANIK, 2009; BARBU; BAKER, 2010).

Mesmo no caso da existência de argumentos segundo os quais as IFRS são inaplicáveis em alguns países específicos, verifica-se que estes ainda as estão adotando como um produto "com efeitos de rede".

Destarte, quando cada entidade segue os mesmos padrões contábeis, se espera que suas demonstrações contábeis sejam comparáveis, facilitando a alocação eficiente de recursos, uma vez que o mercado já não se restringe às fronteiras territoriais.

Essa adequação econômica e social é explicada nos preceitos da Teoria Institucional, que defende a legitimidade explicando o comportamento das organizações diante das pressões isomórficas. Assim, a decisão do país de convergir em direção aos padrões contábeis internacionais faz com que as instituições se enquadrem no que delas tem sido exigido, respondendo às expectativas da sociedade como um todo (BARBU; BAKER, 2010; ALBU et al., 2011). 
A organização reflete, portanto, as regras institucionalizadas e legitimadas dos órgãos que as regulam, sofrendo influências intensas de novos padrões, de políticas, de técnicas e demandas da própria sociedade, tendo o entendimento de que aquilo é o melhor para ela, aliada à compulsoriedade dos órgãos reguladores.

Assim, o processo de convergência internacional de padrões contábeis se realizou dentro de um ambiente altamente institucionalizado, caracterizado por pressões isomórficas em uma base mundial. As pressões isomórficas referem-se ao resultado do processo que tornam as organizações mais similares (DIMAGGIO; POWELL, 1983).

Dimaggio e Powell (1983) afirmam que os campos organizacionais devem ser definidos institucionalmente e baseados em quatro elementos: aumento no grau de interação entre as organizações; surgimento de estruturas Interorganizacionais de dominação e modelos de coalização nitidamente definidos; um aumento na carga de informação com a qual as organizações de um campo devem lidar; e o desenvolvimento de uma consciência mútua entre participantes de um conjunto de organizações que estão envolvidos em um interesse comum.

Os quatro pontos sugeridos por Dimaggio e Powell (1983) permitem a visualização do processo de mudanças enfrentado pelas organizações diante da convergência internacional das práticas contábeis. Todos os elementos são facilmente enquadrados na inserção proposta às organizações, mostrando a necessidade de adequabilidade das instituições diante das alterações provocadas por um novo molde de normas contábeis.

Assim, depreende-se que o processo de convergência internacional de padrões contábeis surgiu justamente da necessidade de se promover a comunicação entre as organizações que passavam pelo aumento do grau de interação em todo o mundo. Surgem, então, entidades responsáveis por efetivar o processo, de maneira que passam a existir alianças ou acordos para fins determinados, exercendo certa influência na vida das organizações. É visível, pela própria necessidade do processo de convergência, que o fluxo de informações à disposição das organizações deve crescer consideravelmente. E, por fim, pode-se dizer que o processo de convergência só vem dando certo, dada a conscientização em prol de um objetivo comum.

Diante desse contexto, percebe-se que o processo de convergência internacional se torna uma força que influencia às organizações a se tornarem similares umas às outras. Dimaggio e Powell (1983) destacam que estratégias vistas como racionais, ao se olhar uma organização individual, nem sempre são tidas assim quando adotadas por um grande número de organizações. No entanto, por serem normativamente sancionadas, provavelmente adotarão os padrões impostos e de fato tornar-se-ão cada vez mais semelhantes. 
Pode-se então, relacionar o processo de convergência internacional de padrões contábeis com o isomorfismo, pois este, conforme Dimaggio e Powell (1983), é um processo de constrangimento que força uma unidade a parecer-se com outras unidades que enfrentam o mesmo conjunto de condições ambientais. Na realidade, a organização se destaca por ser um sistema aberto que é o reflexo de interações ambientais, portanto, influencia o meio e é influenciada por ele, de modo que as organizações vão se adaptando às características do ambiente.

As instituições são afetadas por indivíduos, grupos ou outras organizações e são seus agentes (capazes de influenciar na vida da instituição): gerentes; funcionários; entidades governamentais; reguladores; entre outros (DIMAGGIO; POWELL, 1983; ALBU et al., 2011).

Portanto, em nível demográfico, tal aproximação sugere que características organizacionais se modificam na direção da comparabilidade crescente com características ambientais (DIMAGGIO; POWELL, 1983).

Dimaggio e Powell (1983) tratam de dois tipos de isomorfismo: competitivo e institucional. No caso do processo de convergência internacional, visualiza-se o isomorfismo institucional, pois ele foca as forças que pressionam as organizações, no sentido de adaptar-se ao mundo exterior.

As organizações competem não somente por recursos e clientes (foco do isomorfismo competitivo), mas por poder político e legitimidade institucional (reconhecimento perante a sociedade/meio de se legitimar perante a sociedade), por adequação social, bem como por adequação econômica (DIMAGGIO; POWELL, 1983; LOUNSBURY, 2008; BARBU; BAKER, 2010). Entende-se que a organização busca que a sociedade aceite seus posicionamentos.

O conceito do isomorfismo institucional é um instrumento útil para entender a política e comportamento que penetram na vida de uma organização moderna (DIMAGGIO; POWELL, 1983), promovendo o êxito e a sobrevivência das organizações (MEYER; ROWAN, 1977).

Na ótica de Dimaggio e Powell (1983), existem três tipos de isomorfismo institucional: coercitivo, mimético e normativo.

O isomorfismo coercitivo resulta tanto de pressões formais, quanto de informais exercidas sobre as organizações por outras das quais elas são dependentes e por expectativas culturais da sociedade dentro da qual as organizações funcionam. Essas pressões podem ser sentidas como coerção ou como persuasão (DIMAGGIO; POWELL, 1983). Portanto, o processo de convergência internacional de padrões contábeis pode ser enquadrado nessa ideia, 
considerando que é necessária uma resposta direta por parte das organizações, com o intento de se enquadrar dentro dos trâmites e exigência do processo.

Pode-se dizer que as empresas são coagidas a participar do processo de convergência, primeiro, por parte da compulsoriedade imposta por órgãos reguladores e, segundo, pela própria necessidade imposta pela sociedade no que tange à promoção de mudanças econômicas vivenciadas. Assim, o fato de não interagir com as novas propostas estaria sacrificando a continuidade da organização. A existência de padrões a serem seguidos pelas instituições afeta diversos aspectos do seu comportamento e da sua estrutura.

Dentro do processo de convergência internacional há várias organizações que foram especificamente criadas com o propósito de coagir, como é o caso do IASB, mas que também sofrem pressões de isomorfismo coercitivo no processo de colocação de padrões que resulta em uma influência direta nas práticas e estruturas das instituições, uma vez que passam por pressões isomórficas coercitivas, no sentido de aumentara a qualidade das normas contábeis e promoverem uma maior interação entre os países (BARBU; BAKER, 2010).

Nesse sentido, Dimaggio e Powell (1983) destacam que as estruturas organizacionais cada vez mais refletem regras institucionalizadas e legitimadas por entidades reguladoras. Consequentemente, as organizações ficam cada vez mais homogêneas e organizadas em volta de rituais de conformidade com grandes instituições. Um ambiente altamente institucionalizado exerce pressão sobre as organizações, coagindo-as a adotar estruturas e práticas compatíveis com as expectativas (MEYER; ROWAM, 1977).

É importante destacar que alguns trabalhos identificaram que o impacto do ambiente nacional, tal como aspectos culturais, crescimento econômico, nível de educação, grau de abertura econômica, influência do mercado de capitais, e o processo de implementação das IFRS, impactam na aceitação e na efetividade da adoção das novas normas nos diferentes países (SCHIPPER, 2005; ZEGHAL; MHEDHBI, 2006; BALL, 2006; ALBU et al., 2011). Nessa perspectiva, as instituições poderiam responder diferentemente a esses estímulos e, como consequência, as demonstrações contábeis seriam afetadas.

Nessa lógica, tem-se uma espécie de controvérsia entre uma proposta de uniformidade de padrões contábeis internacionais e as divergências que serão impostas por aspectos econômicos, políticos e culturais. Ball (2006) acrescenta que padrões contábeis internacionais trazem um teor mais subjetivo, sendo baseados em princípios contábeis geralmente aceitos que contém, no mínimo, elementos subjetivos provenientes do julgamento de gerentes e auditores, de forma que provocaria diferenças entre as instituições. Nessa linha, a ideia de uniformidade 
de padrões contábeis parece ingênua. $\mathrm{O}$ autor complementa que o processo estabelecido para impor, por sanção, a uniformidade contábil está longe de ser claro.

Buscando proporcionar melhores explicações acerca da inserção das pressões isomórficas e da dualidade encontrada com as diferenças intrínsecas aos países, encontra-se, na teoria institucional, um respaldo teórico, no sentido de explicar o processo de modificação e interação entre as práticas e rotinas específicas das instituições. As organizações terminam por serem estruturadas conforme as características do ambiente que as cercam, de forma que se tornam isomórficas.

De forma geral, o que de fato ocorre é que as organizações nascem e crescem no mesmo ambiente institucional e, embora características peculiares façam parte da vida de cada entidade, o contato com o ambiente inclina para a similaridade entre elas.

O pressuposto básico é que as organizações são isomórficas, pois entende-se que elas têm aumentado a sua legitimidade e as suas perspectivas de sobrevivência, independentemente da eficácia imediata das práticas e procedimentos adquiridos (MEYER; ROWAN, 1977). A legitimidade é, portanto, o suporte para garantir a sobrevivência.

Influências poderosas de políticas, técnicas, entre outros aspectos institucionais são adotadas rapidamente como padrões convencionais, havendo uma espécie de conformidade a regras institucionalizadas. Adicionalmente, esse tipo de comportamento garante a legitimidade da organização, que, por sua vez, não tem sua conduta questionada (MEYER; ROWAN, 1977).

Muitas das posições das organizações modernas são forçadas pela opinião pública, pelas visões de jurisdições importantes, pelo conhecimento legitimado do sistema educativo, pelo prestígio social, pelas leis, entre outros. Tais elementos da estrutura formal são as manifestações das regras institucionais poderosas que funcionam como padrões altamente racionais que estão amarrando determinadas organizações (MEYER; ROWAN, 1977).

A teoria institucional tem sido utilizada para estudar a prática da Contabilidade nas organizações (DILLARD; RIGSBY; GOODMAN, 2004). A Contabilidade tem, entre suas principais fontes de interesse, a dinâmica das organizações, que, por sua vez, acontece a partir de crenças, culturas, conflitos sociais, regras institucionais, de modo que o mundo está sempre em fluxo, fazendo com que não exista um momento de interrupção, demonstrando que as interações e variações são constantes (LOUNSBURY, 2008).

A teoria em questão propõe que muitos elementos da estrutura organizacional formal, tais como políticas e procedimentos, surgem como consequência das expectativas sociais comuns do que constitui uma prática aceitável (DIMAGGIO; POWELL, 1983; SCOTT, 2007). Em vista disso, a teoria institucional acentua a importância de instituições, bem como a relação 
dos fenômenos, como regras, hábitos, rotinas, normas e cultura. E, de fato, esta armação teórica é útil para entender a Contabilidade e as modificações organizacionais (ALBU et al., 2011).

Desse modo, dentro da perspectiva institucional, a variação de uma prática já existente faz com que seja possível a criação de uma nova. No entanto, para que esta nova prática possa, de fato, se desenvolver, existe a necessidade de que ela seja legitimada, portanto, que tenha reconhecimento social (LOUNSBURY, 2008).

Assim, o processo de convergência internacional tem passado por esse processo de legitimação, tendo sido necessário a criação de um órgão aceito em todas as partes do mundo, que o promovesse e divulgasse. Seguindo os preceitos propostos por Lounsbury (2008), existe um processo coletivo de ação de vários autores, almejando tornar o processo legítimo, tendo necessidade da mobilização de recursos e um movimento de expressão mundial para que pudesse ser aceito por todos aqueles que dele fossem necessitar.

Dessa forma, de fato, a teoria institucional tem sido uma valiosa ferramenta para explicar os fatores específicos que afetam o processo de adoção dos padrões contábeis internacionais, destacando as interações organizacionais entre práticas, rotinas, regras e políticas (ALBU et al., 2011).

É importante acrescentar que as IFRS têm ainda apresentado como benefício, o fato de serem capazes de impactar na reputação de um país, promovendo mais confiança na organização e na qualidade da norma utilizada, ganhando, portanto, legitimidade (JERMAKOWICZ; GORNIK-TOMASZEWSKI, 2006).

O processo de convergência internacional de padrões contábeis tem sido considerado legítimo diante da sociedade, havendo adoção em diversos países, mostrando que há um reconhecimento da necessidade de ceder às pressões isomórficas, na tentativa de salvaguardar a continuidade das instituições.

Isto posto, o poder exercido pela globalização resultou na institucionalização de um novo regime regulador. O reconhecimento da necessidade de se usar novas práticas contábeis pelos países é interpretado como um processo universal de institucionalização, o qual tanto confirma a interdependência entre economias, sistemas políticos, cultura e sociedades, como resulta no aumento da interdependência (AL-OMARI, 2010). Os problemas que ao longo dos anos foram sendo criados pela divergência em padrões contábeis nos diferentes países, em particular na promoção da integração global de economias mundiais, são tão enormes que a pressão da convergência global do padrão contábil tem aumentado cada vez mais (EBIMOBOWEI, 2012). 
O processo de convergência das práticas contábeis se realizou, então, dentro de um ambiente altamente institucionalizado caracterizado por pressões isomórficas dirigidas a uma base mundial (BARBU; BAKER, 2010).

A adoção das IFRS vem, portanto, com a proposta de desenvolver padrões contábeis de alta qualidade. Al-Omari (2010) comenta que o apoio à adoção de padrões contábeis internacionais encontra-se na exigência de que eles ajudem na melhoria e no nível de qualidade das informações contábeis internacionais, aumentando, enfim, a credibilidade da informação contábil.

Parte-se de uma corrente segundo a qual as IFRS fornecem um quadro mais realista de ganhos e perdas do que os padrões nacionais. As IFRS trouxeram uma informação de alta qualidade, sendo transparente e comparável, de forma que investidores, credores, analistas financeiros e outros usuários de informações financeiras poderão utilizá-las para a tomada de decisões. Os padrões de qualidade fazem com que as informações contábeis sejam compreensíveis e respondam às necessidades dos usuários, permitindo comparações e restringindo o gerenciamento de resultados, evitando que os elaboradores enganem ou disfarcem a informação (AL-OMARI, 2010).

A adoção de novos padrões contábeis pode ainda ser delineada em termos técnicos ou institucionais. Da perspectiva técnica, as organizações são recompensadas para o controle eficaz e eficiente do processo de trabalho, ao passo que, sob uma perspectiva institucional, a adoção de novas práticas cria imperativos de conformidade para as firmas ganharem legitimidade (AL-OMARI, 2010).

Partindo do pressuposto de que as IFRS contribuem, de forma geral, para o aumento da qualidade da informação contábil, pode-se focar ainda nas contribuições em termos da redução da assimetria informacional e consequente impacto no aumento da liquidez de mercado e do custo de capital. Assim, de fato, todos esses fatores são determinantes de variações no risco, pois, a partir do momento em que o investidor tem acesso a informações contábeis de qualidade, sua percepção em torno das expectativas de risco é modificada.

Impactos econômicos provocados pelas IFRS têm sido retomados em diversos aspectos, e a análise do risco pode ser um deles, pois, a medida que a informação contábil é alterada, temse efeitos sobre sua qualidade e sobre a precificação dos ativos, em razão do fato de que são encadeados efeitos sobre o risco, o qual é presente em toda decisão de investimento e recebe vestígios diretos e indiretos de todos os fatores aqui discutidos.

Nesse sentido, vale salientar que o efeito que as IFRS podem produzir na avaliação do risco pode ser encarado como uma das suas formas de legitimação, uma vez que sua adoção 
pode ser justificada pela possibilidade de interferir nas decisões de investimento, nas quais o risco exerce forte influências.

\subsection{Variável Risco}

A literatura aponta, de forma geral, que a avaliação do risco associado a um determinado ativo constitui a preocupação central para os investidores. Por esse ângulo, Fernandes, Souza e Faria (2010) destacam que, entre as informações priorizadas pelos investidores, quando necessitam decidir onde investir, estão as informações sobre risco.

No mesmo sentido, Amorim, Lima e Murcia (2012) destacam que um dos pontos cruciais para se avaliar um ativo é saber o nível de risco a que este ativo está sujeito. A despeito desse foco no aspecto "risco" e, também, a despeito das afirmações encontradas na literatura que trata do assunto sobre as preocupações dos investidores, há que se considerar que risco pode, eventualmente, significar coisas distintas, para avaliadores distintos. Assim, cabe indagar: Afinal, o que o investidor determina como risco do investimento?

Inicialmente, deve ser destacado que o conceito de risco não é um conceito fechado e restrito a todas as situações. De forma geral, o risco se refere à possibilidade de perder ou não perder determinado bem ou direito.

O risco é a probabilidade de a expectativa que orienta uma decisão não se concretizar. Isto pode ocorrer pelo fato de não conhecermos tudo o que vai acontecer. Assim, o risco tem a ver com as incertezas vinculadas aos acontecimentos futuros.

Bernstein (1997) destaca que o risco é a medida da nossa ignorância, portanto, diz respeito à incerteza de se alcançar os retornos esperados. Em outros termos, risco e incerteza são conceitos que estão intrinsecamente ligados, onde existe um evento de ocorrência incerta e existe o risco de ele ocorrer ou não. De tal forma, uma definição do termo risco pode ser a demonstração numérica da incerteza. Cabe ressaltar que Morgan e Henrion (1990) colocam a incerteza como um componente essencial do risco, de modo que não pode existir risco se não existir incerteza.

No entendimento de Bernstein (1997), o risco é uma opção, de forma que é determinado pelas ações que se ousa tomar, as quais são dependentes do grau de liberdade do indíviduo. A tomada de decisão que envolve o risco está no cotidiano de qualquer ser humano, remetendo a alocar os recursos da saúde pública, conduzir a guerra, o planejamento da família, pagar prêmios de seguros, até a usar o cinto de segurança. 
Bernstein (1997) já destacava que o risco não só existia na ameaça, mas se encontrava presente também nas oportunidades. Assim, o risco aparece presente tanto na possibilidade de acontecer resultados abaixo do esperado como acima destes.

Segundo Amorim, Lima e Murcia (2012, p. 200), “de maneira geral, o risco é associado à possibilidade de que algum acontecimento desfavorável venha a ocorrer". Essa conotação será aqui enfatizada, pois remete ao fato de que o risco estaria associado diretamente a uma perda ou a um não ganho, em que, de fato, na perspectiva do investidor, a visão é sempre que o risco circunda a possibilidade de que o retorno esperado não ocorra. Dessa maneira, esse retorno poderia não acontecer, tendo-se o risco de se perder todo o capital aplicado, ou ser menor do que se esperava.

Para Bernstein (1997), o risco é um desafio a ser encarado sobre distintos aspectos. Por consequência, o risco pode ser tipificado em diversas especificidades. Dentro dessa ótica, qual seria o risco ao qual está submetido o investidor?

Quando o investidor precisa tomar uma decisão a respeito de qual tipo de investimento será realizado, é possível que diferentes fatores influenciem a sua tomada de decisão, desde fatores técnicos do investimento até fatores comportamentais.

Acredita-se que a maximização de riqueza é a meta primordial em qualquer investimento, sendo a intenção fazer com que determinado capital aumente, ou ao menos que as decisões reduzam o impacto de prováveis perdas futuras. No entanto, a presença do risco torna as decisões de investimentos bem mais sensíveis, considerando que dado o risco, não é possível se prever com exatidão quanto determinado investimento vai trazer de retorno.

Assim, é possível destacar que na realização do investimento existe sempre a figura da incerteza, presente em qualquer decisão realizada, de forma que não se sabe ao certo se haverá ganhos ou perdas. No entanto, o risco passa a existir efetivamente quando se toma a decisão. Como se nota, o risco representa uma questão de opção, significando que o investidor a ele submetido pode ou não ter o retorno esperado.

Pode-se dizer que o foco do investidor é o retorno esperado. No entanto, Fama (1970) destaca que o retorno de um título é função do seu risco. Nessa linha, parte-se do pressuposto de que não se "vence o mercado", excluindo-se a possibilidade de retornos excedentes, de maneira que não se alcança uma taxa de retorno mais alta que a passível de ser justificada pelo risco do investimento.

A ideia defendida é, portanto, que a relação risco-retorno sempre será mantida em situações de equilíbrio, sendo impraticável obter uma taxa de retorno mais alta do que prudentemente é justificado no risco que está se incorrendo. 
Fama (1970) desenvolveu a hipótese do mercado eficiente, a qual está amparada no pressuposto de que os investidores são racionais, isto posto, os investidores avaliam os títulos pelo seu valor intrínseco, ou seja, pelo fluxo de caixa futuro descontado pela taxa de juros, na qual se inclui o risco da operação. Nessa acepção, a relação risco-retorno está sempre presente nas decisões de investimento.

Portanto, na hipótese do mercado eficiente, a racionalidade do investidor especifica que determinado nível de risco só deverá ser enfrentado a partir da possibilidade de se alcançar determinado retorno.

A ideia da racionalidade considera que, quando o investidor recebe novas informações, faz a atualização de suas crenças, como que englobando novas variáveis ao processo decisório. Aliado a isso, dadas as suas crenças, considerando a visão do cenário de decisão, os agentes fazem escolhas que são normativamente aceitáveis, pois são consistentes com a Teoria da Utilidade Esperada (BARBERIS; THALER, 2002).

A teoria da utilidade foca que, em condições de incerteza, o investidor escolherá aquelas alternativas que maximizariam a sua riqueza, ou seja, sua decisão seria racional, fazendo uso das informações disponíveis de uma forma lógica e sistemática para escolher aquela que tenha mais utilidade (FRIEDMAN; SAVAGE, 1948; BERNOULLI, 1954).

Bernoulli (1954) enfoca que é evidente que nenhum investidor aceita determinado risco se não enxergar uma utilidade compatível com ele. De forma geral, investidores estão sempre buscando investimentos que lhes proporcionem maiores taxas de retornos e que essas, por sua vez, sejam submetidas a níveis de riscos mínimos. Um investidor que esteja disposto a realizar investimentos que possuam elevadas taxas de retornos esperados está, também, propício a enfrentar grandes riscos.

Toda a ideia da racionalidade se baseia no pressuposto de que o agir racionalmente seria o ato de processar e aproveitar todas as informações disponíveis sem que houvesse interferência de qualquer fator emocional. No entanto, Kahneman e Tversky (1979) destacaram que escolhas, entre as perspectivas de risco, apresentam vários efeitos intensos que são inconsistentes com os princípios básicos da teoria da utilidade, os quais provêm de fatores comportamentais.

Kahneman e Tversky (1979) destacam que as diferentes pessoas não atribuem o mesmo peso aos retornos prováveis. Existem percepções particulares e se dão pesos distintos a retornos apenas prováveis em comparação com aqueles a serem obtidos com certeza. Essa tendência, o chamado efeito de certeza, contribui para a aversão ao risco nas escolhas que envolvem certeza de ganhos e risco de perdas. Logo, uma pessoa é avessa ao risco, se ele prefere a perspectiva certa para qualquer perspectiva arriscada, independentemente do valor esperado. 
Friedman e Savage (1948) relatam que os indivíduos, frequentemente, selecionam entre as alternativas que se diferenciam, entre outras coisas, no grau do risco ao qual o indivíduo será sujeito. Na mesma linha, Weber e Hsee (1998) destacam que a preferência em relação aos riscos denota a escolha de pessoas quando enfrentam duas opções que são iguais no valor esperado, mas se diferenciam em uma dimensão assumida no impacto no risco das opções.

Friedman e Savage (1948) focam em responder perguntas quanto à coerência existente entre as escolhas que os indivíduos fazem: os indivíduos negligenciam o elemento risco? Ou o risco desempenha um papel central na tomada de decisão? Qual é o verdadeiro papel do risco? Consequentemente, reforçam que a importância dada à variável risco pode mudar de indivíduo para indivíduo, e diversos fatores podem ser tratados como justificativa: a falta de informação, a idade (disposição aventureira) e o fato de que alguns indivíduos são mais atraídos pelas perspectivas de um grande êxito do que são desencorajados pelo medo do fracasso.

Weber e Hsee (1998) reforçam que existem pessoas que realmente têm uma atitude positiva em direção ao risco, de forma que algumas delas podem selecionar uma opção de volatilidade mais alta ao invés de uma opção mais baixa, tendo ambas valor esperado igual; isto é, eles realmente procuram a opção que percebem serem mais arriscadas.

Kahneman e Tversky (1979) também identificaram alguns resultados que, em vez de resultarem aversão ao risco, havia o comportamento de busca ao risco, tal como visualizaram comportamentos diferenciados quando se está tratando de riscos de ganhos em relação ao risco de perdas. Em alguns pontos, os autores chegaram a afirmar que os dados trabalhados não seriam compatíveis com a noção de que a certeza é geralmente desejável.

O estudo de Kahneman e Tversky (1979) investigou também que, quando se tem a possibilidade de se investir em um empreendimento com alguma probabilidade de perder o capital, se a empresa falhar, e em outro que existe a opção de um fixo acordado retornar, independentemente do desempenho, e se for bem-sucedido angariar uma porcentagem dos lucros, haverá o efeito de isolamento, que implica que a certeza contingente do retorno fixo aumenta a atratividade dessa opção. Assim, as preferências podem ser alteradas por diferentes representações de probabilidades.

Tudo isso se dá devido à impressão subjetiva com relação aos riscos. Dessa maneira, a utilidade esperada não é a única explicação das escolhas que envolvem riscos, até porque, como destaca Bernoulli (1954), a utilidade varia segundo as perspectivas de cada indivíduo, inclusive ele coloca como exemplo que um homem de poucas posses geralmente obtém mais utilidade de um ganho igual a que terá um homem com muitas posses. O autor acrescenta ainda que há homens a quem pouco dinheiro significa mais do que muito dinheiro significa para outros que 
são menos ricos, mas mais generosos do que aqueles. Dessa forma, nem sempre a teoria da utilidade, com seu pressuposto de racionalidade, pode justificar as decisões tomadas. Weber e Hsee (1998) apontam que as razões para as diferenças nas preferências dos riscos correspondem a mecanismos psicológicos distintos.

Weber e Hsee (1998) investigaram ainda se diferenças culturais impactam na percepção dos riscos e nos trabalhos realizados, de modo que encontrou posicionamentos diferenciados, os quais podem ser explicados pela cultura.

Kwak e Dewan (2001) destacou que existem muitos fatores internos e externos, visíveis e invisíveis, que influenciam o ambiente e que criam alto risco na realização dos objetivos de determinado projeto, tais como: cultural; socioeconômico; tecnológico; político e ambiental; falta de recursos gerenciais e tecnológicos; os objetivos do projeto são pouco claros; escassez de recursos; falta de posse; infraestrutura de má qualidade para o desenvolvimento do projeto; forças externas - tais como inflação, câmbio e política internacional. Esses fatores representariam os principais majorantes do risco.

Bernoulli (1954) destaca que não há nenhuma razão para se supor que duas pessoas tenham as mesmas reações diante de riscos idênticos. Pode ser razoável que alguns indivíduos invistam em um empreendimento duvidoso e, apesar disso, não ser razoável para outros fazêlo.

Dessa maneira, como se pode saber se o risco que se corre é elevado ou não? Se está dentro de um nível aceitável ou não? As ocupações diferenciam-se muito na variabilidade do rendimento que eles prometem (FRIEDMAN; SAVAGE, 1948).

Por conseguinte, não existe uma resposta única para determinar o risco aceitável por cada investidor, trata-se de uma questão pessoal e variável diante das diferentes situações. A decisão do investidor será então condicionada à forma de lidar com situações incertas, tanto quanto as suas preferências em relação ao equilíbrio risco e retorno esperado.

Dentro desse contexto, é possível perceber que fatores comportamentais podem reduzir a capacidade que a informação tem de contribuir no processo decisório do investidor, uma vez que, mesmo de posse de informações que indicam para determinada escolha, o investidor pode ser "irracional" e agir de contra o esperado. Porém, espera-se que a disponibilidade da informação possa inibir o comportamento não racional.

Conforme Lintner (1965), os prêmios variam segundo o risco ao qual se está exposto. Como também determinaram Kahneman e Tversky (1979), que o componente sem risco, ou seja, o ganho certo ou a perda mínima que é determinada a ser obtida ou paga, é "comumente" 
preferível. A presença do risco sempre é compensada através do ganho adicional ou prêmio esperado.

Deste modo, estão presentes - na decisão de investidores em situações de incertezas suas preferências em relação ao equilíbrio risco/retorno. Os investidores exigem uma taxa para participarem do negócio, a taxa de retorno, e, quanto maior o risco associado, maior a taxa de retorno exigida. A lógica é que tais variáveis possuem uma relação positiva, isto é, investidores exigiriam um prêmio para financiar projetos cujo retorno esperado é mais volátil (AMORIM; LIMA; MURCIA, 2012, p. 200).

A decisão com racionalidade seria selecionar os investimentos que apontarem um risco menor e um maior retorno esperado, ou seja, diante de um mesmo nível de risco, opta-se pelo investimento que apresentar a maior expectativa de retorno, e se o nível de retorno for igual, a escolha será pela opção que apresentar o menor risco.

Nesse contexto, é importante destacar que, na hipótese da eficiência de mercado, o valor do investimento será, portanto, fruto das preferências dos investidores diante do retorno esperado. Nesse ponto de vista, o preço do ativo reflete as informações disponíveis aos investidores, de modo que os preços incorporarão as expectativas dos investidores.

De forma geral, o pressuposto da racionalidade e maximização da riqueza, segundo os preceitos da teoria da utilidade, seria uma forma de facilitar os estudos empíricos sobre as decisões dos investidores, permitindo fazer inferências próximas das situações práticas.

Nessa lógica, uma questão passa a ser certa, sendo as reações dos investidores diferenciadas diante do risco, mas que de forma geral, independentemente do risco assumido, o foco ficará na busca pela maximização do capital investido; pode-se dizer que a informação será o impulso para alimentar essa relação.

De fato, a informação dará segurança ao investidor, estabelecendo consistência à negociação. Seria uma forma de poder traçar cenários diferenciados, estabelecendo previsões de possíveis reações futuras, podendo se ter um maior leque de alternativas de decisão.

Dentro do conjunto de informações disponíveis ao investidor, no sentido de lhe proporcionar bases concretas para um processo decisório mais efetivo, com maiores chances de se alcançar a maximização de riqueza, encontra-se a informação contábil.

A informação contábil tem se mostrado relevante, considerando que pode alterar potencialmente o processo decisório, ajuda a melhorar previsões de eventos futuros, confirmar o resultado de previsões anteriores e é suficiente para traçar diversos cenários de decisão. Nessa perspectiva, questões incertas em torno do risco serão trabalhadas a partir da informação contábil, verificando os reais impactos sobre a negociação, qual a disponibilidade do investidor 
diante dos diversos cenários e até mesmo buscar condições em que as incertezas, geradoras de risco, sejam diminuídas.

No trabalho de Markowitz (1959), o risco foi tratado como diversificável (nãosistêmico) e não-diversificável (sistêmico). O diversificável seria um risco voltado às atividades empresariais, sendo passível de gerenciamento. Já o risco sistêmico seria o risco intrínseco ao mercado, onde a ocorrência de determinados eventos de natureza política, econômica e social podem influenciar os ativos negociados.

O risco gerenciável pode-se dizer que é controlável, uma vez que existem diversas formas de minimizá-lo, embora seja importante ressaltar que ele não pode ser evitado totalmente, mas apenas reduzido, de forma que, por melhor que seja a diversificação possível, ela simplesmente minimiza os riscos, devido a essa incerteza residual de qualquer nível dado de retorno (LINTNER, 1965).

O objetivo da diversificação é, então, produzir a melhor carteira - aquela com a combinação mais favorável de risco e retorno esperado - e, assim, investidores que são "avessos ao risco" estão buscando a "carteira ótima", de forma a atingir o nível de risco mais baixo (LINTNER, 1965).

Segundo Markowitz (1959), o risco diversificável depende de encontrar a melhor forma de lidar com especificidades do ativo, trabalhando de maneira que se encontre uma carteira ótima de investimento. Diante disso, busca-se uma carteira com um menor nível de risco em equilíbrio com o maior retorno esperado possível. A ideia é combinar, em uma carteira, ativos de forma a encontrar as melhores relações risco e retorno, sempre diminuindo o risco e aumentando o retorno esperado.

Conquanto, é importante destacar que uma gestão de riscos bem-sucedida e eficaz requer uma compreensão clara dos riscos enfrentados pelo investimento. Isso envolve mais do que simplesmente listar os riscos identificados e caracterizá-los por sua probabilidade de ocorrência e impacto nos objetivos (retorno esperado). A grande quantidade de dados de risco produzidos durante o estudo do processo deve ser estruturada de forma a ajudar a sua compreensão e interpretação e para permitir que possa ser utilizado como uma base para a ação (HILLSON, 2002).

Markowitz (1959) acrescentou que era importante trabalhar os ativos da carteira de forma a não existir forte correlação positiva entre o retorno dos ativos da carteira, caso contrário, não haveria diversificação. Dessa maneira, o ativo não deveria ser avaliado pelo risco individual, mas por sua participação no risco total da carteira. 
Diante disso, é possível aceitar a ideia de que, para um investidor racional, o risco nãodiversificável é o que importa, uma vez que para o risco diversificável ter-se-ia o gerenciamento, sendo possível reduzí-lo significativamente. No caso do risco nãodiversificável, não existe essa possibilidade, pois ele está ligado a eventos de grande magnitude, de tal forma que não são eliminados pela diversificação.

Assim, é fato que o risco não-diversificável tem sido a principal preocupação do investidor, considerando que ele está presente em eventos econômicos que não estão sob o seu domínio. Easley, Hvidkjaer e O’Hara (2002) destacam que o risco diversificável não deve ser mantido, o investidor tem formas de trabalhá-lo, de maneira que não haverá nenhuma compensação de mercado para a presença desse tipo de risco. Já no caso do risco nãodiversificável não se tem controle, podendo apenas tentar manter o melhor equilíbrio risco e retorno, de forma que os investidores são compensados por maiores retornos esperados para manter este risco.

As discussões sobre como a informação contábil se relaciona com o risco ganham ênfase, com vistas a incrementar os argumentos à disposição do investidor para a sua tomada de decisão, de modo que algumas delas têm indicado associações significativas entre variáveis contábeis e medidas de risco sistêmico, como as pioneiras de Beaver, Kettler e Scholes (1970), Hamada (1972), Gonedes (1973), Gonedes (1975), Beaver e Manegold (1975), Bowman (1979) e Hill e Stone (1980).

Beaver, Kettler e Scholes (1970) apresentaram destaque aos números contábeis, afirmando que os mesmos são capazes de gerar informações consideradas por muitos como medidas de risco sistêmico, sendo útil para ajudar o investidor a determinar o perfil de risco de uma companhia, e que o Beta contábil pode ser um substituto do Beta de mercado, quando esta medida não está disponível. No período de realização da pesquisa, a Contabilidade foi uma das fontes de informação mais invocadas para se medir risco para investidores.

Hamada (1972) também usou números extraídos dos relatórios contábeis, especificamente os que determinam a estrutura de capital (endividamento e alavancagem), para demonstrar que estão relacionados com o risco sistêmico, chegando à conclusão de que existe influência da estrutura de capital no risco sistêmico.

Gonedes (1973) teve como objetivo fornecer algumas evidências empíricas sobre o conteúdo informativo dos números contábeis, tendo a atenção direcionada para os retornos. Partindo de questionamentos acerca da capacidade dos números contábeis de transmitirem informações acerca do risco de um ativo, o autor apresenta algumas reflexões sobre os modelos e as amostras utilizadas em pesquisas sobre o assunto e conclui que os posicionamentos 
divergentes e os resultados de algumas estimativas podem induzir inferências injustificadas. Foram apresentadas ainda evidências sobre a correlação entre as estimativas de risco sistêmico e números contábeis.

Em 1975, Gonedes realizou um trabalho com o objetivo de apresentar evidência adicional sobre a mesma questão trabalhada por ele mesmo em 1973, e os resultados apresentados sugeriram, mais uma vez, que há uma associação estatiscamente significante entre os números contábeis e o risco sistêmico. $\mathrm{O}$ autor ainda acrescenta que, em alguns pontos do artigo anterior, onde não tinha encontrado uma relação estatisticamente significativa, foi indicado que o modelo estava mal especificado em relação à inadequação do índice utilizado.

Beaver e Manegold (1975) ressaltaram que as informações disponibilizadas ao investidor afetam avaliações de risco, uma vez que a informação altera o valor esperado do investimento e o risco associado. Destacam ainda que a chegada da informação no mercado, em geral, não afeta somente o equilíbrio entre risco e retorno de cada investidor individual (ou seja, a composição da carteira, bem como o montante total atribuído entre investimento e consumo atual), mas também o equilíbrio de todo o mercado (ou seja, os preços, as taxas livres de risco, bem como o valor do risco).

Bowman (1979), objetivando fornecer uma base teórica para a pesquisa empírica sobre a relação entre o risco sistêmico e as variáveis financeiras (Contábeis), além de testar sua relação com variáveis adicionais (variabilidade dos resultados, política de dividendos, tamanho ou crescimento de uma empresa), verificou que há uma relação teórica entre o risco sistêmico, a alavancagem da firma e o Beta contábil. Os resultados indicaram que algumas variáveis financeiras (Contábeis) são altamente correlacionadas com uma medida de risco (Beta) do mercado e são úteis na predição de risco futuro. Também se determinou que o risco sistêmico não é uma função de variabilidade de lucro, crescimento, tamanho ou política de dividendo. $\mathrm{O}$ autor destaca que as suposições empregadas fornecem um modelo muito geral e que relações adicionais entre o risco sistêmico e outras variáveis podem ser obtidas impondo suposições mais restritas.

Hill e Stone (1980) destacam a importância de se relacionar medidas contábeis com o risco de mercado, dando a possibilidade de explicar, predizer e lidar com suas instabilidades. Portanto, as implicações são amplas e têm inferências para muitas áreas como Contabilidade, Finanças e Economia, por exemplo.

Amorim, Lima e Murcia (2012) destacam que o nível de risco a que um ativo está sujeito é base para a avaliação de investimentos. O risco seria um componente fundamental presente na taxa de desconto utilizada para que se encontre o valor presente dos fluxos futuros. O risco 
de não ter o retorno esperado é então a principal preocupação do investidor, de forma que os investidores exigem um prêmio para financiar o projeto que tem seu retorno esperado volátil.

Considerando que as informações contábeis têm conteúdo informacional e influenciam na formação dos preços dos ativos, Amorim, Lima e Murcia (2012) reforçam que, nessas condições, pode-se dizer que a informação contábil tem capacidade de prover o acesso aos parâmetros de construção da variável risco.

Watts e Zimmerman (1986) já destacavam que se os lucros contábeis são informações aproximadas dos fluxos de caixa, o $\beta_{C}$ (covariância entre os lucros da firma e os lucros de mercado, dividido pela variância dos lucros de mercado) seria também um aproximador do $\beta$ do investimento. Por consequência, os lucros contábeis podem ser usados para obter estimativas de risco.

Nesse sentido, se o valor de um projeto de investimento é igual ao valor presente dos fluxos de caixa futuros, descontados pela taxa de retorno exigida (onde está presente o risco do investimento), e as informações contábeis alteram as expectativas direcionadas aos fluxos de caixa futuros, principalmente com relação à exposição ao risco, pode-se dizer que as informações contábeis alteram as taxas de retorno requeridas; portanto, o risco, consequentemente, afeta os preços dos ativos.

Easley, Hvidkjaer e O'Hara (2002) estudaram como os fatores econômicos influenciam nos preços dos ativos, havendo uma preocupação de estudar a inserção do efeito provocado pela informação no ambiente e como isto se reflete no preço. Ao considerar que existem informações privadas em circulação, as quais não serão refletidas no preço, dada a ineficiência de mercado, vai haver impacto no risco e, por isso, ter-se-á efeito no equilíbrio risco e retorno. Portanto, a assimetria informacional afeta a qualidade da informação e afeta o risco do investidor.

Easley, Hvidkjaer e O’Hara (2002) ainda colocam que o problema de seleção adversa, faz com que os investidores exijam um prêmio de risco maior, pois a transparência com relação ao investimento será menor e a incerteza de retorno do capital aplicado será maior.

Jermakowicz e Gornik-Tomaszewski (2006) colocam que entre os fatores que poderiam levar à volatilidade aumentada em resultados financeiros expostos às IFRS, comparando com resultados que teriam sido informados de acordo com padrões locais, incluem: reconhecimento de mais grupos de ativos financeiros e obrigações em valor justo; existência de regras mais resistentes em alguns tipos de registros e tratamento de prejuízos; além de exigências mais conservadoras no reconhecimento de alguns tipos de ganhos e de perdas estimadas.

Por conseguinte, em uma análise mais ampla em termos dos efeitos no ambiente político-econômico, pode-se dizer que o processo de convergência internacional afeta o 
mercado de capitais e, portanto, o risco. Isso porque o referido processo propõe mudanças na informação contábil, o que acarretarão alterações nas expectativas dos investidores, de forma que haverá variações na formação do risco.

Nesse contexto, no país em que forem adotadas as IFRS, pode haver mudanças significativas na qualidade da informação acarretando alterações no risco do investidor. Uma maior qualidade da informação implica um risco menor, posto que, ao se aumentar atributos qualitativos da informação, tal como redução da assimetria informacional e outros, deverá haver diminuição da incerteza e, portanto, redução do risco.

No entanto, um dos problemas que tem atormentado aqueles que tentam prever o comportamento do mercado de capitais é a ausência de uma teoria microeconômica restrita para lidar com condições de risco. Dessa forma, tem-se buscado uma alternativa para suprir aquela lacuna nos modelos teóricos de apreçamento de ativos por arbitragem, como uma forma de direcionar as discussões e auxiliar no gerenciamento do risco de mercado (SHARPE, 1964).

Fundamenta-se, em alguns dos modelos mais citados pela literatura para apreçar um ativo, que são o CAPM (Capital Asset Pricing Model) e o APT (Arbitrage Pricing Theory).

A base de sustentação do CAPM ressaltada por Sharpe (1964), é que os preços dos ativos são ajustados de acordo com as variações no risco de mercado. Nas condições que o mercado esteja em equilíbrio, os modelos de precificação permitem determinar a medida relevante de risco para qualquer ativo e a relação entre este e o retorno esperado.

A ideia é a de que os agentes cobram um prêmio para assumir o risco do investimento, que seria justamente a incerteza quanto ao retorno. Portanto, a imprevisibilidade do retorno aumenta o risco sobre o ativo.

O CAPM, que é conhecido como um modelo de formação de preços de ativos de um único fator, é tido como o modelo que trabalha com um conjunto mais restritivo de hipóteses (ELTON et al., 2004).

Segundo Elton et al. (2004), a validade do CAPM depende de se aceitar que algumas complexidades que teriam efeito pequeno ou nulo sobre o mundo real, não existem. Nesse caso, consideram-se hipóteses que se coadunam com a hipótese do mercado eficiente, conforme seguem:

1- Não existem custos de transação;

2- Os ativos são infinitamente divisíveis;

3- Ausência de imposto de renda da pessoa física;

4- Um indivíduo não é capaz de influenciar o preço de uma ação através de suas compras ou vendas; 
5- Acredita-se que os investidores tomem decisões somente em termos de valores esperados e desvios-padrão dos retornos de suas carteiras;

6- É permitido fazer vendas a descoberto;

7-É possível aplicar e captar fundos à taxa livre de risco em quantidades ilimitadas.

8-Supõe-se que os investidores se preocupam com a média e com a variância dos retornos (ou preços) num único período;

9- Os investidores têm expectativas idênticas em relação aos dados necessários para a otimização das carteiras.

10- Todos os ativos são negociáveis.

Essa espécie de simplificação da realidade teria por propósito tentar compreender, efetivamente, os fenômenos reais, uma vez que, se não houver o relaxamento de certos pressupostos ficaria impossível de se testar no mundo real.

Fama e French (2007, p. 104) ressaltam que “os problemas empíricos do CAPM podem refletir falhas teóricas resultantes de um grande número de premissas simplificadoras".

O CAPM em sua versão mais básica foi desenvolvido por Sharpe (1964), Lintner (1965) e Mossin (1966), sendo trabalhado dentro do pressuposto de que os investidores farão gerenciamento de risco através de combinações de ativos e, no geral, se concentram na carteira de Mercado e em um ativo livre de risco. Essa possibilidade existe, pois, ao se aplicar em fundos com taxa livre de risco, tem-se como identificar o risco a que se está propenso, mesmo sem levar em conta as preferências do investidor em relação a este. A Figura 1 expõe graficamente essa linha de raciocínio.

Figura 1 - Fronteira Eficiente

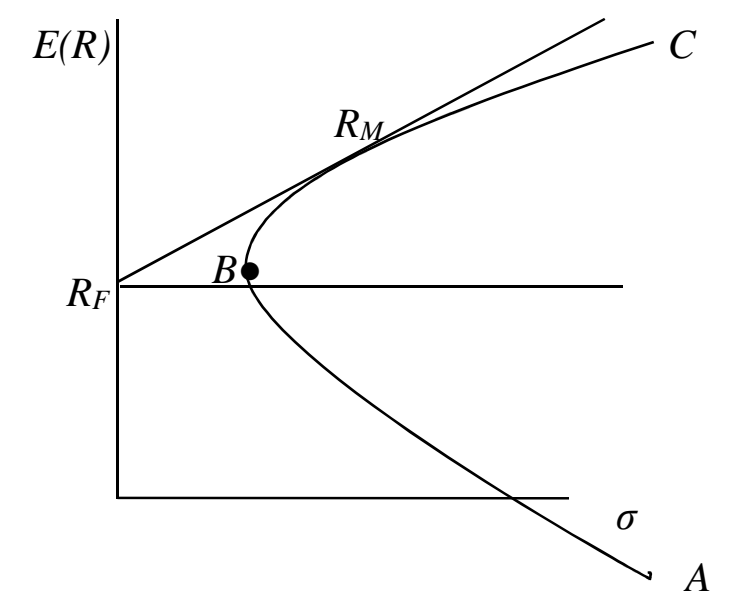

A variável $\mathrm{R}_{\mathrm{F}}$ diz respeito à linha do retorno dos títulos livres de risco (Risk Free). A que indica o retorno do mercado é $\mathrm{R}_{\mathrm{M}}$ !

Fonte: Elton et al. (2004, p. 263) 
Onde $R_{M}$ é a carteira de ativo com risco, que será considerada como a carteira de mercado, pois contém a expectativa de qualquer investidor, sendo formada por todos os ativos com risco existentes. A linha $R_{F}$ é a linha de mercado de capitais, na qual todas as carteiras eficientes se encontrariam, de forma que, comumente, as carteiras de ativos se encontram abaixo dessa linha. Dessa forma, no estudo do comportamento dos preços das ações, é notório que, quando o mercado oscila para cima, a maioria das ações tende a subir seus preços, e se a oscilação for para baixo, estes tendem a cair.

O CAPM foi o primeiro a preconizar que o risco relevante na realização de um dado investimento é o risco sistêmico, porque o risco não-sistêmico pode ser trabalhado por meio de um portfólio diversificado, tendendo a zero.

Se um único fator determina uma importante parcela da variação dos preços dos ativos, é possível explicar a variação do retorno de cada investimento pela sua sensibilidade ao fator (risco sistêmico) e a variação restante por componentes específicos (risco não- sistêmico). Nesse caso, a diversificação permite ao investidor buscar evitar todos os tipos de risco, exceto o risco que resulta do equilíbrio da atividade econômica, esse tipo do risco permanece até em combinações eficientes (SHARPE, 1964). O risco sistêmico é medido pela dispersão dos excessos de retorno devido a fatores externos ao mercado.

Então, o componente do risco total que não pode ser diversificado é o risco sistêmico, sendo esse passível de ser quantificado pelo Beta, que, por sua vez, mede a extensão na qual os retornos do ativo e o mercado se movem em conjunto. Formalmente, o Beta é definido como uma variável que descreve a sensibilidade ou a capacidade de reação de um investimento em relação ao movimento de mercado (equilíbrio da atividade econômica). Mede, portanto, a volatilidade dos retornos de um título com relação aos retornos de mercado como um todo (SHARPE, 1964).

\footnotetext{
O único motivo pelo qual as ações variariam em conjunto, de forma sistemática, seria uma variação conjunta comum com o mercado. Não existiriam outros efeitos além do mercado (por exemplo, efeitos setoriais) que fossem responsáveis pelo movimento conjunto entre títulos (ELTON et al., 2004, p. 130).
}

Empiricamente, o risco sistêmico é frequentemente estimado pela aplicação do modelo dos mínimos quadrados ordinários (OLS - Ordinary Least Squares), conforme Equação 1.

$$
R_{i t}=\alpha_{i}+\beta_{i} R_{m t}+u_{i t}
$$


Onde $R_{\text {it }}$ representa o retorno de um ativo $i$ no tempo $t ; R_{m t}$ representa o retorno do mercado no período $\mathrm{t} ; u_{\mathrm{t}}$ é o termo de erro, uma variável de ruído branco aleatório. Beta da ação, $\beta_{\mathrm{i}}$, é o coeficiente que mede a variação esperada de $R_{\mathrm{it}}$ dada uma variação de $R_{\mathrm{mt}}$ e $\alpha_{\mathrm{i}}$ é o intercepto. $\mathrm{O} \beta i$ mede a sensibilidade do retorno de uma ação ao retorno do mercado.

As estimativas de $\alpha_{\mathrm{i}}, \beta_{\mathrm{i}}$ e $u_{\mathrm{t}}$ são geralmente obtidas com o uso de análise de regressão, pois trata-se de uma técnica que garante que $u_{\mathrm{t}}$ e $R_{\mathrm{mt}}$ sejam não correlacionados, isso no período para o qual a equação é ajustada e são estimados como constantes e não como variáveis que se alteram no decorrer do tempo.

O modelo mais simples de comportamento do Beta assume $\beta_{i t}=\beta$ para todo o período. No entanto, a investigação de Odaba (2003) mostrou empiricamente que Betas verdadeiros parecem variar no decorrer do tempo. Godeiro (2012) também enfoca a discussão existente em torno do Beta, na qual alguns trabalhos admitem que o Beta é constante ao longo do tempo (Beta estático) e outros rejeitam essa linha de pensamento, assumindo-o como dinâmico.

Desta forma, uma das principais questões a ser resolvida em testes de Betas que sofrem variações no tempo, é como a sua instabilidade poderá ser modelada. O conceito básico de Beta surge porque todas as ações tendem a se mover em certa medida, com a evolução do mercado em geral (BRADFIELD, 2003).

Para o trabalho aqui realizado, será adotado o Beta como dinâmico, uma vez que este é uma melhor aproximação do risco de mercado, pois ele consegue captar períodos de crise (GODEIRO, 2012, p. 52). O Beta constante poderia ser usado apenas como uma referência, mas não como uma boa medida de risco.

O Beta é então uma medida que variará quando as condições de estabilidade do mercado tenderem a não existir e, no caso de as tendências econômicas serem estáveis, havendo continuidade na administração das firmas, o Beta será relativamente estável quando estimado em diferentes períodos de tempo.

Jagannathan e Wang (1996) reforçam que a maior parte dos estudos empíricos assumem o CAPM como estático, de forma que admitem que os Betas permanecem constantes com o tempo. Porém, existe um consenso geral de que o CAPM estático é incapaz de explicar, satisfatoriamente, a seção transversal de retornos médios sobre as ações. Assume-se que o CAPM mantém um sentido condicional, isto é, os Betas e os prêmios de risco de mercado variam ao longo do tempo.

Wang (2003) coloca que modelos dinâmicos do CAPM têm, em geral, um melhor desempenho que modelos estáticos, uma vez que são mais desafiadores, considerando que não 
têm um guia mostrando como o Beta responde a variáveis que representam informações de condicionamento. E, a despeito das limitações, o CAPM continua a ser aceito como um modelo válido para determinar o valor de um ativo pelos agentes do mercado.

Considera-se que o Beta contém unicamente risco sistêmico representando o mercado de capitais, admitindo-se que o risco não-sistêmico foi todo suprimido pela diversificação. A estimação do Beta está baseada, então, em medir o grau de volatilidade de um ativo às mudanças no comportamento do mercado, de forma que, todos os ativos terão o preço alterado, em maior ou menor proporção, a partir da existência de alteração no mercado como um todo.

Assim, em termos generalistas, o Beta pode ser representado pela Equação 2 (SHARPE, 1964; LINTNER, 1965).

$$
\beta=\frac{\operatorname{COV}_{x, y}}{\operatorname{VAR}_{x}}
$$

Considerando que a covariância é calculada a partir do retorno de mercado $(\mathrm{x})$ em relação ao retorno de um título ou índice (y). E a variância é medida pelo retorno de mercado $(\mathrm{x})$.

O valor do $\beta$ é único, sendo o valor que separa o retorno devido ao mercado do retorno que é particular, fazendo com que a covariância entre $R_{\mathrm{mt}}$ e $u_{\mathrm{t}}$ seja igual a zero.

Assim, o risco de um ativo único é medido pela covariância entre os retornos de um título à variabilidade dos retornos do mercado, dessa forma, o Beta do mercado é igual a um, pois a correlação de qualquer variável aleatória com ela mesma é igual a um. Qualquer ativo que tenha risco superior ao do mercado deveria ter Beta maior que um. Inversamente, qualquer título com risco inferior ao mercado teria um Beta menor que um (ver quadro 1) (LINTNER, 1965).

Quadro 1 - Relação entre o risco sistêmico e o risco de mercado
\begin{tabular}{|l|l|}
\hline $\mathrm{B}<1$ & $\begin{array}{l}\text { O ativo tem um risco sistêmico menor do que o risco } \\
\text { de mercado. }\end{array}$ \\
\hline $\mathrm{B}=1$ & $\begin{array}{l}\text { O ativo tem um risco sistêmico igual ao risco de } \\
\text { mercado. Existe uma correlação perfeita entre os } \\
\text { retornos do ativo e os retornos do mercado. }\end{array}$ \\
\hline $\mathrm{B}>1$ & $\begin{array}{l}\text { O ativo tem um risco sistêmico maior do que o risco } \\
\text { de mercado. }\end{array}$ \\
\hline $\mathrm{B}=0$ & $\begin{array}{l}\text { O ativo não possui risco sistêmico. Isso é típico dos } \\
\text { chamados ativos livre de risco. }\end{array}$ \\
\hline
\end{tabular}

Fonte: (SHARPE, 1964; LINTNER, 1965). 
Nessa ótica, pode-se retomar a análise da Figura 1, para dizer que todos os ativos e todas as carteiras de ativo deveriam estar situadas sobre uma linha reta e, se o título estiver acima ou abaixo, haveria uma oportunidade de arbitragem sem risco. Quanto maior o Beta, maior o retorno em equilíbrio, isso em uma relação linear. No geral, títulos com Betas altos são mais arriscados e espera-se que produzam retornos mais elevados, pois estão expostos a um maior risco.

\subsection{Pesquisas Anteriores}

Desde que o processo de harmonização das práticas contábeis começou a ser discutido e, posteriormente, o processo de convergência começou a se consolidar, diversas pesquisas foram realizadas, no intuito de buscar identificar se a proposta do órgão internacional de desenvolver normas de Contabilidade de alta qualidade tem sido alcançada. Passa-se a refletir a respeito das razões apresentadas pelo governo e órgãos normatizadores para que os padrões locais fossem substituídos pelas IFRS.

No geral, buscou-se responder se a adoção de normas internacionais de Contabilidade, conforme prenunciavam os órgãos normatizadores, de fato estava promovendo o aumento da qualidade da informação contábil. Nesta linha, os pesquisadores dedicaram esforços, no sentido de identificar os benefícios proporcionados pela adoção das IFRS ou, em último caso, se eles efetivamente existem.

A determinação da qualidade da informação contábil tem sido avaliada por diversas óticas, tais como: transparência; governança corporativa; gerenciamento de resultados; relevância; conservadorismo; persistência; confiabilidade; fidedignidade de representação; neutralidade; entre outros; e até mesmo se procurado identificar como a qualidade da informação responde através da interação da adoção com o ambiente econômico, com vistas a relacionar aspectos da cultura, do sistema legal, político, dentre outros.

No geral, existe, por parte do IASB, a defesa de que as práticas contábeis de reconhecimento, mensuração e divulgação postas pelas IFRS apresentam maior qualidade informacional. Soderstrom e Sun (2007) destacam que os estudos remetem ao fato que a adoção das IFRS veio melhorar a qualidade da informação contábil, mas que os estudos empíricos têm apresentado resultados inconclusivos.

A explicação das divergências entre as pesquisas que serão aqui discutidas sobre qualidade da informação contábil pós IFRS, não necessariamente reside no fato de que os 
estudos empíricos apontam para a não alteração da qualidade da informação contábil, mas pode estar atrelada à intensidade de fatores que podem interferir na variável qualidade, porquanto questões econômicas, culturais, políticas, do sistema legal, entre outras, podem provocar uma adequação diferenciada ao padrão internacional, de país para país.

Adicionalmente, os modelos trabalhados pelos pesquisadores na realização das pesquisas sobre qualidade da informação, também podem influenciar as diferenças entre os resultados, em razão de que os modelos podem responder diferentemente de acordo com as características do país ao qual estão sendo aplicados, sendo tal aspecto normalmente apontado como limitação nas pesquisas realizadas.

Utilizando-se da biblioteca virtual da Coordenação de Aperfeiçoamento de Pessoal de Nível Superior - o portal de periódicos da CAPES, buscou-se investigar as pesquisas trabalhadas no tema estudado nesta tese, no âmbito internacional e nacional. Assim, o levantamento de pesquisas internacionais foi realizado utilizando-se palavras-chave como: quality; accounting information; accounting quality; IAS; IFRS. As mesmas palavras-chave foram utilizadas para as pesquisas nacionais, sendo então referenciadas no idioma local.

Leuz (2003), motivado pelo debate sobre os padrões contábeis uniformes no mundo, investigou se as empresas que utilizam as normas dos Estados Unidos apresentam diferenças em relação as normas internacionais no que tange à assimetria de informações. As empresas envolvidas são listadas no novo mercado da Alemanha. Como resultado, a pesquisa constatou que a escolha entre as normas internacionais e as normas dos Estados Unidos parece ser de pouca importância para a assimetria de informações e liquidez do mercado, pois, não apresentam diferenças significativas em termos de assimetria informacional. Assim, tanto as IAS como os US GAAP apresentaram redução da assimetria informacional.

Prather-Kinsey e Shelton, 2005, investigaram se os relatórios financeiros, conforme as então IAS, resultam em divulgações de qualidade, levando em conta diferenças institucionais e as forças de mercado. O estudo se concentrou nos accruals discricionários como medida de gerenciamento de resultados e proxy para qualidade da informação contábil. Utilizaram-se os US GAAP como ponto de referência para medir a qualidade das IAS quando aplicadas na África do Sul e no Reino Unido. Os resultados do estudo indicam que fatores institucionais e as forças de mercado influenciam na qualidade das informações contábeis, pois um mercado emergente como o da África do Sul se mostrou praticando um maior gerenciamento de resultados, ao contrário do Reino Unido onde os gestores são mais conservadores e têm maior inibição sobre o gerenciamento de resultados, apresentando maior qualidade da informação contábil. Este estudo fornece elementos de prova acerca da qualidade das informações financeiras preparadas 
de acordo com as IAS e sua dependência em relação aos fatores institucionais e as forças de mercado de um país.

Barth et al. (2006), preocuparam-se em comparar firmas dos Estados Unidos que estavam usando as normas internacionais com firmas que não as usavam, buscando identificar se a qualidade da informação contábil variava por causa da presença da norma internacional. Investigou-se os seguintes atributos: gerenciamento de resultado; conservadorismo e valuerelevance. No caso dessa análise específica, o resultado encontrado sugeriu que as firmas dos Estados Unidos que não estavam usando normas internacionais tinham normas que produziam informações de qualidade superior, no entanto, as normas internacionais são próximas das normas dos Estados Unidos, de forma que as diferenças não foram intensas. Para as demonstrações contábeis consolidadas, o resultado com relação à qualidade da informação foi o mesmo para ambos os tipos de firmas.

Na mesma linha da comparação das normas internacionais com as normas dos Estados Unidos, Van Der Meulen, Gaeremynck e Willekens (2007) investigaram a qualidade da informação contábil de firmas listadas no mercado alemão que divulgavam suas informações com base nas IFRS ou das normas dos Estados Unidos. A qualidade da informação contábil foi medida aplicando-se múltiplos atributos da informação do lucro, tais quais: value-relevance, oportunidade; capacidade preditiva e gerenciamento de resultados. Constantemente, em todas as análises das medidas utilizadas, encontrou-se que a qualidade das informações elaboradas segundo as normas dos Estados Unidos é, em geral, muito comparável com as informações das IFRS. Só quanto à capacidade de predição da informação contábil é que foi encontrado superioridade das normas dos Estados Unidos.

Observa-se, nos quatro estudos comentados, que quando se iniciou o debate sobre a adoção de padrões contábeis internacionais, teve-se um grande foco comparativo em relação aos US GAAP, o qual era considerado como padrão mundial em termos de qualidade da informação contábil, justificando assim, que, ao se estudar a qualidade dos padrões contábeis internacionais a referência para comparação fossem os US GAAP.

Callao, Jarne e Laínez (2007) realizaram estudo em um grupo de empresas na Espanha que foram obrigadas a utilizar as IFRS. O estudo se concentrou nos efeitos das novas normas sobre a comparabilidade e a relevância da informação contábil. Os resultados demonstraram que, de fato, a comparabilidade é bastante afetada no uso das IFRS em relação às normas contábeis locais. Não houve indícios de aumento no value-relevance das informações contábeis. Nesse contexto, pode-se dizer que o impacto potencial das IFRS depende de muitos fatores, 
inclusive se o padrão contábil anterior era ou não de qualidade, ou ainda quão próximo era do padrão IFRS.

Barth, Landsman e Lang (2008) examinaram se a aplicação das normas internacionais de Contabilidade está associada ao aumento da qualidade da informação contábil. Foram estudadas firmas de 21 países, usando o período antes e pós adoção e focando os seguintes atributos de qualidade: gerenciamento de resultado, conservadorismo e value-relevance. Verificou-se que as empresas que aplicaram as normas internacionais de Contabilidade geralmente apresentaram uma melhoria na qualidade da informação contábil nos períodos pós adoção, de forma que apresentaram menor gerenciamento de resultados, maior conservadorismo e maior value-relevance.

Daske et al. (2008), com o propósito de examinar as consequências econômicas da adoção das IFRS ao redor do mundo, analisaram os efeitos na liquidez de mercado e no custo de capital em 26 países. O aumento da liquidez de mercado e a redução do custo de capital seriam sinalizações de aumento na qualidade da informação contábil. Os resultados encontrados foram que, em média, a liquidez de mercado aumentou no período de adoção das IFRS. Também se documentou que houve uma redução no custo de capital e aumento no preço das ações das empresas, mas nesse ponto em específico o resultado só foi confirmado antes da data de adoção das IFRS, o que pode ser justificado como uma possível antecipação dos efeitos ocasionados pela adoção da IFRS. Porém, os achados permitiram concluir que os benefícios do mercado de capitais ocorreram só em países onde as firmas têm estímulos para serem transparentes e onde a influência legal é forte, sublinhando a importância do incentivo à divulgação e enforcement.

Morais e Curto (2009) investigaram se o value-relevance das informações contábeis das empresas europeias cotadas no mercado de capitais aumentou após a aplicação obrigatória das IFRS, além de identificar como o value-relevance das informações contábeis elaboradas e apresentadas segundo as IFRS é moldado por fatores específicos do país em que as empresas estão domiciliadas. Os resultados mostram que o value-relevance da informação contábil no período de aplicação obrigatória das IFRS pelas empresas é maior do que no período em que elas aplicaram padrões locais de Contabilidade. Isso parece sugerir que a adoção obrigatória das IFRS aumentou a relevância do conteúdo informacional da informação contábil. Encontrouse, também, que nos países onde a Contabilidade e a parte fiscal são claramente separados, as informações contábeis são mais relevantes. Finalmente, se descobriu que empresas de países com fortes exigências jurídicas e públicas na aplicação da Contabilidade, apresentou um menor value-relevance da informação quando da aplicação das IFRS. 
Zhou, Xiong e Ganguli (2009) investigaram se as firmas que adotam IFRS têm a qualidade do lucro mais alta em se tratando de um mercado emergente (China). Os resultados sugerem alguma melhora na qualidade da informação contábil associada à adoção das IFRS. As firmas adotantes têm menor gerencimento de resultados no pós-adoção. No entando, não houve indícios de aumento do conservadorismo.

Foi realizado por Li (2010), um estudo que examinou se a adoção obrigatória das IFRS na União Europeia, em 2005, reduziu o custo de capital próprio, ou seja, aumentou a qualidade da informação contábil, tendo sido encontradas evidências de que, em média, a adoção das IFRS reduziu significativamente o custo de capital próprio. Os achados também demonstraram que essa redução está presente apenas em países em que se verificou forte incentivo à divulgação e enforcement. Dessa forma, foi possível se afirmar que o aumento da divulgação e a maior comparabilidade da informação são dois mecanismos por trás da redução do custo do capital próprio.

Iatridis (2010) procurou determinar se a adoção das IFRS levava a uma maior qualidade das informações contábeis. O estudo concentrou-se no Reino Unido e examinou os seguintes atributos de qualidade: gerenciamento de resultados, value-relevance, conservadorismo e a não existência de assimetria informacional. Os achados mostraram que a implementação das IFRS geralmente reforça a qualidade contábil. Identificou-se que houve redução no gerenciamento de resultados, que houve um maior conservadorismo no reconhecimento das perdas e que se aumentou o value-relevance, além de sugerir-se uma menor assimetria informacional.

Lee et al. (2010) pesquisaram 17 países Europeus, em períodos de pré e pós adoção das IFRS, de modo a investigar o efeito no custo de capital das firmas, no sentido de verificar se houve melhoria na qualidade da informação contábil e, portanto, redução do custo de capital. Foram calculados o custo de capital das firmas através das previsões consensuais de analistas e de preços de mercado específicos das empresas. Nos países que têm mais baixo incentivo para divulgação e enforcement, a evidência quanto à redução do custo de capital próprio foi limitada, mas nos países em que o incentivo à divulgação e enforcement era acima da média, verificouse uma redução significativa do custo de capital próprio.

Aubert e Grudnitski (2011) tiveram como objetivo analisar o impacto econômico e a importância da adoção obrigatória das IFRS em firmas da União Europeia, tendo estudado treze países. Foram estudadas diferenças na variável de retorno sobre o ativo quando estavam sob o efeito das IFRS e das normas locais, de forma a se investigar o impacto econômico, tendo sido encontradas diferenças positivas significativas. Nos testes aos atributos de value-relevance e tempestividade do lucro, ao analisar cada empresa especificamente não se observou melhoria 
na qualidade da informação contábil. Mas, em amostra combinada de todos os países, encontrou-se um impacto diferencial em termos de tempestividade do lucro e value-relevance ao se comparar as normas locais com as IFRS, o que denota um indício de aumento da qualidade da informação contábil. Poucos países mostraram aumento na qualidade, destacando a qualidade dos accruals discricionários (diminuição do gerenciamento de resultados).

Liu et al. (2011) examinaram o impacto das IFRS na qualidade da informação contábil na China, um mercado regulamentado, com ênfase no gerenciamento de resultados e valuerelevance. Os resultados suportam a hipótese de que a qualidade da Contabilidade melhorou significativamente com a adoção obrigatória das IFRS, substancialmente convergentes na China. A qualidade melhorou com a diminuição do gerenciamento de resultados e o aumento do value-relevance dos números da Contabilidade na China.

Khanagha (2011) também examinou a value-relevance da informação contábil nos períodos pré e pós adoção das IFRS nas companhias dos Emirados Árabes Unidos. Os achados mostraram um declínio no value-relevance da informação contábil depois da adoção das IFRS.

Na mesma linha, Chalmers, Clinch e Godfrey (2011) investigaram se a adoção das IFRS aumenta o value-relevance das informações contábeis para as empresas listadas na Australian Securities Exchange. Descobriu-se um aumento do value-relevance para a informação do lucro, não tendo se encontrado o mesmo resultado para a informação da variável patrimônio. Consistente com o aumento no value-relevance, o lucro também torna-se mais persistente em torno da adoção das IFRS. O estudo sugeriu que mesmo para um país categorizado por forte proteção dos investidores e relatórios financeiros de alta qualidade, a adoção das IFRS afeta a associação entre informações contábeis e o valor de mercado.

Qu, Fong e Oliver (2012) examinaram se a adoção das IFRS melhorou a qualidade da informação contábil de investidores no mercado de ações na China. Os achados da pesquisa revelaram que os investidores confiavam na informação divulgada sobre o lucro por ação, mostrando que, nos períodos pré e pós convergência das IFRS, verificou-se que o lucro por ação é um fator explicativo do retorno do mercado, ou seja, existe conteúdo informacional e, de fato, os investidores sentem-se seguros para tomar decisões. No entanto, a confiança dos investidores na informação sobre a distribuição de dividendos ficou maior pós adoção das IFRS. No geral, o processo de convergência aumentou o conteúdo informacional do lucro e, assim, aumentou a qualidade da informação contábil.

Landsman, Maydew e Thornock (2012) examinaram se o conteúdo da informação de anúncios de lucro aumentou em países que adotaram as IFRS em comparação com países que conservaram padrões contábeis domésticos. Foram pesquisados 16 países que adotaram as 
IFRS e 11 países que conservaram padrões contábeis domésticos. Tomado no conjunto, os resultados são compatíveis com um aumento no conteúdo de informação do lucro depois da adoção obrigatória das IFRS. Foi encontrado, ainda, que as firmas de países com maior enforcement experimentaram maior modificação no conteúdo da informação.

Jansson, Jonsson e Von Koch (2012) investigaram se a implementação das IFRS tem aumentado a qualidade contábil, com ênfase na qualidade de previsões de analistas financeiros. A amostra abrange cinco países europeus (Suécia, Países Baixos, França, Alemanha e Reino Unido). Os resultados sugerem que a adoção das IFRS não teve nenhum efeito sobre a precisão das previsões em geral quando se tratou de países onde a norma anterior diferia significativamente das IFRS. O país mais afetado de forma consistente é o Reino Unido, onde a precisão da previsão parece melhorar (países com padrão anterior semelhante às IFRS). Há algumas indicações de que a relação entre as IFRS e precisão das previsões é ligeiramente mais positiva em empresas com maior proporção de ativos intangíveis. $\mathrm{Na}$ maioria dos países, a dispersão (sinal da extensão da discordância de analistas) da previsão parece diminuir como um efeito das IFRS, o que seria um indício de redução da assimetria informacional e pertinente a um aumento na qualidade da informação contábil.

Kargin (2013) investigou o value-relevance da informação contábil em períodos pré e pós-aplicação das IFRS em firmas turcas. Em geral, os resultados mostraram que o valuerelevance da informação contábil melhorou no período Pós-IFRS.

Nulla (2013) investigou se a adoção das IFRS nas empresas de pesquisa e desenvolvimento canadenses melhorou a qualidade das informações contábeis das empresas. A pesquisa constatou menor persistência e previsibilidade nos lucros (menor qualidade); diminuição do conteúdo da informação do lucro para a formação do valor da empresa pelo acionista (menor qualidade); menor volatilidade no preço de mercado (maior qualidade); melhor previsibilidade do fluxo de caixa e previsões financeiras (maior qualidade); e aumento do conservadorismo (maior qualidade); e diminuição dos gastos em pesquisa e desenvolvimento (não tem relação com a qualidade). A qualidade da informação contábil pós adoção das IFRS foi afetada tanto positivamente, quanto negativamente, o que permite afirmar que a qualidade contábil tem a influência variada nas demonstrações contábeis das companhias de pesquisa e desenvolvimento canadenses.

Dimitropoulos et al. (2013) analisaram o impacto da adoção das IFRS sobre a qualidade das informações contábeis na grécia. Encontraram-se evidências convincentes de que a implementação das IFRS contribuiu para um menor gerenciamento de resultados, maior conservadorismo e maior value-relevance dos números contábeis (comparando com os 
números contábeis locais). Destarte, sugere-se aumento na qualidade da informação contábil pós-adoção das IFRS.

Brochet, Jagolinzer e Riedl (2013) examinaram se a adoção obrigatória das IFRS leva benefícios ao mercado de capital pela comparabilidade das informações financeiras. Em conjunto, os achados são compatíveis com o fato de que a adoção das IFRS obrigatória melhora a comparabilidade e assim leva a benefícios ao mercado de capital reduzindo a capacidade de usuários internos de explorar a informação privada. A melhoria da qualidade da informação também foi atrelada a ambientes que as normas locais se apresentavam semelhantes às IFRS.

Houqe, Easton e Van Zijl (2014) analisaram os efeitos da adoção das IFRS obrigatória sobre a qualidade das informações contábeis na França, Alemanha e Suécia (os três países são caracterizados como de baixa proteção ao investidor). Concluiu-se que a adoção obrigatória das IFRS tem um efeito positivo sobre a qualidade da informação em países com baixa proteção ao investidor, podendo-se inferir que, quanto menor é a força de proteção ao investidor, maior é o efeito sobre a qualidade da informação. Identificou-se significativa melhora na exatidão de previsão de analistas depois da adoção obrigatória das IFRS nos três países.

Elshandidy (2014) investigou o value-relevance da informação contábil em segmentos diferentes do mercado de capitais chineses. Os resultados sugerem que a informação contábil, baseada nas IFRS convergidas com normas locais, tenha provavelmente maior value-relevance do que aquele observado para a informação contábil baseada em normas locais.

Martínez, Martínez e Lin (2014) examinaram os efeitos da introdução das IFRS sobre o value-relevance na Grécia. Os resultados fornecem evidências consideráveis de que a adoção das IFRS não implica aumento no value-relevance. Entretanto, os resultados a partir do teste de value-relevance incremental mostram que os investidores consideram os ajustes individuais de conciliação valiosos e significativos. Além disso, os resultados foram significativamente mais elevados para as empresas de baixa alavancagem.

No âmbito nacional, também se encontraram pesquisas que se preocuparam em verificar se a inclusão de um país no processo de convergência internacional de padrões contábeis, de fato traziam melhorias para a qualidade da informação contábil.

Vieira (2010) analisou se houve aumento na qualidade das informações contábeis no Brasil entre os períodos pré e pós-adoção parcial por meio da análise do gerenciamento de resultados, reconhecimento oportuno de perdas e a relevância das informações contábeis. Encontra-se indícios que levam a crer que houve aumento na qualidade das informações contábeis quando medidas por gerenciamento de resultados. Quanto ao reconhecimento oportuno de perdas, foram encontrados resultados conflitantes, alguns demonstrando aumento 
de qualidade e outros não. Para a relevância da informação contábil, os indícios, em todas as amostras, são de que houve aumento na qualidade das informações.

Lima (2011) investigou o papel dos incentivos individuais das companhias no compromisso com o atendimento das práticas de convergência as IFRS, e o impacto da adoção destas práticas no custo de capital e liquidez de mercado no Brasil, um país emergente caracterizado por distinto ambiente institucional e elevadas oportunidades de crescimento. Os resultados indicam que os incentivos (efeitos nas empresas: maiores; menos alavancadas; maiores oportunidades de crescimento; maior rentabilidade; estrutura de propriedade e controle mais difusas; auditadas por big four) são importantes determinantes do comportamento das empresas frente ao atendimento das práticas de convergência. O custo de capital e a liquidez de mercado parecem estar relacionados ao compromisso das empresas com o atendimento das práticas de convergência as IFRS. Os resultados apresentam indícios de que a adoção do modelo contábil internacional pode implicar melhoria no ambiente informacional das empresas.

Macedo et al. (2011) analisaram o impacto da substituição da Demonstração das Origens e Aplicações de Recursos (DOAR) pela Demonstração dos Fluxos de Caixa (DFC), implementada pelas mudanças nas normas contábeis brasileiras vigentes para o exercício de 2008. Para tanto, analisa-se a questão do value-relevance das origens de recursos das operações provenientes da DOAR e do fluxo de caixa operacional (FCOPA) proveniente da DFC das empresas não financeiras de capital aberto listadas na base de dados Melhores e Maiores da FIPECAFI-EXAME. As evidências empíricas encontradas apontam que o FCOPA é mais relevante que as Origens de Recursos das Operações para o mercado de capitais, sugerindo que a substituição da DOAR pela DFC foi benéfica para os usuários da informação contábil no Brasil, pois acrescentou relevância às informações.

Santos et al. (2011) avaliaram se, após a vigência da Lei n. ${ }^{\circ}$ 11.638/07, que estabeleceu o marco regulatório de convergência do padrão contábil nacional para as IFRS, o nível de conservadorismo condicional das empresas brasileiras com ações negociadas na BM\&FBOVESPA modificou. Os resultados encontrados não permitem inferir se as novas regras tiveram algum efeito sobre o grau de reconhecimento assimétrico de perdas e ganhos, ou seja, sobre o conservadorismo. Assim, não se rejeitou a hipótese de não haver efeito no conservadorismo condicional das empresas pesquisadas.

Rodrigues (2012) fez um estudo que buscou analisar a qualidade decorrente da adoção dos padrões internacionais de Contabilidade de maneira global, depois, em dois grupos de países, envolvendo o grupo dos mais desenvolvidos e os emergentes, e por país individualizado. A pesquisa foi focada nas seguintes dimensões de qualidade: persistência; conservadorismo; 
gerenciamento de resultados e value-relevance. Em observação ampla, se percebe que os resultados inferem um aumento do conteúdo informacional e do value-relevance, para as outras dimensões, pode-se dizer que o comportamento pré e pós adoção das IFRS foi bastante similar. Ressalva para um ou outro país, como o caso da África do Sul e da China, que aumentaram o conservadorismo pós adoção das IFRS. Em vista disso, de maneira geral, se podendo afirmar que os padrões internacionais de Contabilidade, considerando as dimensões analisadas, não contribuíram para o aumento da qualidade da informação contábil.

Macedo, Machado e Machado (2013) compararam a relevância da informação contábil em períodos pré e pós a primeira fase do processo de convergência às normas internacionais de Contabilidade no Brasil. Os resultados mostraram diferenças no value-relevance da informação contábil de Lucro Líquido (ganho de conteúdo informacional) e Patrimônio Líquido (perda de conteúdo informacional) nos períodos pré e pós primeira fase do processo de convergência.

Paulo et al. (2013) analisaram o efeito da adoção das IFRS na qualidade dos lucros reportados pelas empresas públicas brasileiras e europeias. Os resultados demonstraram menor persistência no lucro (menor qualidade), não houve nenhum indicativo de mudanças significativas no conservadorismo da informação contábil e no gerenciamento de resultados (sem efeito na qualidade da informação contábil). De forma geral, a pesquisa mostrou que a qualidade da informação contábil não melhorou significativamente, comparando o período antes e depois da adoção das IFRS no Brasil ou na Europa.

Macedo et al. (2013) tiveram como objetivo analisar o impacto do processo de convergência às normas contábeis internacionais no Brasil, sobre o conteúdo informacional da Contabilidade, com foco na investigação dos principais índices contábeis-financeiros e na relevância das informações contábeis. Os resultados apontaram que os indicadores pesquisados, quando utilizados dados das demonstrações em full IFRS, indicavam lucros superiores, o que poderia ser explicado pelo menor conservadorismo contábil. Quanto à capacidade informacional do Lucro Líquido, foi possível detectar que, no padrão full IFRS, o Lucro Líquido aumentou seu poder explicativo sobre o comportamento dos preços das ações. Assim, de fato, houve um aumento na qualidade da informação contábil, considerando que, no geral, houve ganho no conteúdo informacional.

Grecco (2013) avaliou se as mudanças nas práticas contábeis brasileiras trouxeram redução no gerenciamento de resultados das empresas abertas brasileiras não financeiras, ocasionando uma melhoria na qualidade da informação contábil. Os achados permitiram concluir que não houve alteração no gerenciamento de resultados após a convergência às IFRS. 
Silva (2013) investigou o impacto da adoção completa das IFRS na qualidade das demonstrações contábeis e no custo de capital próprio das empresas brasileiras de capital aberto. Restringindo-se à análise do gerenciamento de resultado, conservadorismo condicional relevância, tempestividade e o custo de capital próprio. Os resultados revelam que os accruals discricionários estimados diminuíram no período da adoção completa. Observou-se um aumento no conservadorismo condicional. Os modelos de relevância e tempestividade revelam um aumento em ambas às dimensões da qualidade da informação contábil. Aceita-se a hipótese de aumento na qualidade da informação contábil após a adoção completa das IFRS. Sugere-se uma redução no custo de capital em torno de 7 pontos-base das empresas.

Santos, Starosky Filho e Klann (2014) estudaram se o processo de convergência às normas contábeis internacionais impactou o value-relevance das informações contábeis evidenciadas por companhias abertas brasileiras. Os resultados mostraram que houve aumento no value-relevance das demonstrações contábeis após a convergência, mas é possível que outros fatores relacionados às características institucionais do país tenham influenciado os resultados.

Joia e Nakao (2014) estudaram se houve mudança nos níveis de gerenciamento de resultados após 2010 e se foi em função da adoção completa das IFRS pelas companhias brasileiras de capital aberto (com exceção das instituições financeiras). Os resultados não indicaram mudança no gerenciamento de resultados, de forma que não foi possível afirmar que a adoção das IFRS alterou a qualidade da informação contábil.

Santos e Cavalcante (2014) avaliaram o efeito da adoção das IFRS no Brasil sobre a relevância informacional do lucro contábil das firmas de capital aberto. A relevância está representada nas seguintes dimensões: capacidade associativa com o preço das ações; tempestividade informacional e nível de conservadorismo do lucro contábil. Os resultados obtidos indicaram que a adoção das IFRS no Brasil: (1) aumentou a capacidade associativa do lucro contábil; (2) reduziu a tempestividade informacional; e (3) não surtiu efeitos sobre o conservadorismo condicional. Da análise conjunta das evidências empíricas obtidas na presente pesquisa, conclui-se que não é possível afirmar que a adoção das IFRS no Brasil contribuiu com o aumento da relevância informacional do lucro contábil das firmas de capital aberto.

Martins et al. (2014) analisaram os reflexos do processo de convergência na qualidade da informação contábil e, mais especificamente, avaliar se esses possíveis reflexos se comportam de forma distinta para as companhias listadas nos níveis diferenciados de governança corporativa (NDGC), em oposição às empresas em geral. As métricas da qualidade da informação utilizadas foram: relevância, por meio de um modelo de value-relevance, 
conservadorismo e tempestividade. As principais evidências indicaram que o conservadorismo das empresas estudadas diminuiu ao longo do processo de convergência, porém, o grau de redução das empresas listadas nos NDGC foi inferior ao das demais, não tendo sido possível afirmar se tal fato foi ou não benéfico para os usuários das informações contábeis. No que se refere à tempestividade, observou-se que as empresas listadas nos NDGC se apresentaram mais oportunas antes do processo de convergência, porém, com o processo de adoção das IFRS, o nível de tempestividade não foi distinto entre os grupos de empresas. Isso sugere que a adoção do padrão IFRS contribuiu positivamente no que se refere ao atributo da tempestividade para as empresas que não estão listadas nos NDGC. Observou-se, também, que a relevância das informações contábeis melhorou com a adoção das IFRS, sendo que, antes e durante a adoção parcial, as informações referentes às empresas aderentes aos NDGC apresentaram um maior nível de relevância do que as demais. Entretanto, com a adoção integral não se verificou distinção.

Klann e Beuren (2015) verificaram a influência do processo de convergência às normas contábeis internacionais no nível de suavização de resultados de empresas brasileiras. Os resultados apontam elevação nos níveis de suavização de resultados após a convergência, testando através da variabilidade no lucro e através da razão entre o lucro e o fluxo de caixa operacional. Apenas quando se testou a correlação entre o fluxo de caixa operacional e os accruals, não se encontraram resultados significativos. Conclui-se que a efetividade do processo de convergência das normas contábeis do país às normas internacionais, a fim de obter melhoria na qualidade da informação contábil, não depende apenas da convergência das normas contábeis.

Alguns outros trabalhos, em quantidade até bem mais expressiva, ainda se preocuparam em estudar qual o impacto da adoção das normas internacionais de Contabilidade quanto às características específicas dos países, tendo havido preocupação com aspectos como: história; sistema legal; cultura; interferências da legislação tributária; entre outros, porém aqui, essas pesquisas não foram referenciadas, pois se preocupou-se efetivamente com a relação do processo de convergência internacional com a qualidade das informações contábeis.

As pesquisas que aqui estão, não apontam para uma verdade absoluta em termos de se afirmar que a adoção das IFRS aumenta a qualidade da informação contábil, onde alguns resultados corroboram com esta defesa, outros não, o que pode ter sido proporcionado pelos ambientes diferenciados de aplicação das IFRS, influências econômicas, políticas, culturais, além do próprio modelo econométrico utilizado para a pesquisa, o que, realmente, pode bem propiciar resultados diferentes. No entanto, não era intenção deste levantamento de pesquisas 
defender que realmente existe qualidade da informação contábil ou mesmo de provar se ela, de fato, existe ou não. A intenção é demonstrar a necessidade de aprofundamento sobre o tema e despertar para as nuances a serem exploradas.

Na realidade, Bruggemann, Hitz e Sellhorn (2013) fazem reflexões interessantes segundo as quais alguns resultados das pesquisas empíricas estão comprometidos, pois aplicam medidas agregadas que capturam só um subconjunto de modificações potenciais nas informações contábeis, portanto, não estariam trabalhando com o modelo econométrico adequado para a proposta. Além disso, os estudos empíricos podem exagerar os efeitos macroeconômicos e seus reflexos no mercado de capitais, já que é difícil separar o efeito da adoção das IFRS dos efeitos de modificações simultâneas não relacionadas com as informações contábeis, que é o que integrou uma das principais preocupações desta pesquisa, tendo sido empreendido um considerável esforço, no sentido de encontrar modelos econométricos que pudessem amenizar essa limitação.

No intuito de ampliar a compreensão quanto ao foco desse estudo, reforçando assim o seu ineditismo, a partir das palavras chaves market risk, beta e accounting information realizouse um levantamento que apresenta as pesquisas em torno do tema risco e informação contábil (Ver Quadro 2). 
Quadro 2 - Pesquisas do tema Risco x Informação contábil

\begin{tabular}{|c|c|c|}
\hline & & \\
\hline AUTORES & OBJETIVO & RESULTADOS \\
\hline $\begin{array}{l}\text { Ismail, Kim e Kirk } \\
\text { (1994) }\end{array}$ & $\begin{array}{l}\text { Uso de informações contábeis na } \\
\text { previsão de betas nas categorias } \\
\text { extremas de riscos. }\end{array}$ & $\begin{array}{l}\text { Os achados revelam que a inclusão de medidas dos } \\
\text { riscos contábeis melhora substancialmente a } \\
\text { previsão de beta para os títulos de alto risco. }\end{array}$ \\
\hline Kim e Ismail (1998) & $\begin{array}{l}\text { Mede a capacidade das medidas } \\
\text { contábeis no processo de } \\
\text { entendimento da relação risco- } \\
\text { retorno no mercado de capitais. }\end{array}$ & $\begin{array}{l}\text { Os resultados mostram que medidas de risco (betas) } \\
\text { com base nos lucros e no fluxo de caixa, são } \\
\text { consistentes com as expectativas da hipótese de } \\
\text { prêmio de risco e, sendo assim, sugerem que as } \\
\text { medidas contábeis podem ser adequadas aos } \\
\text { portfólios com risco ascendentes e descendentes. }\end{array}$ \\
\hline $\begin{array}{l}\text { Baginski e Wahlen } \\
\text { (2003) }\end{array}$ & $\begin{array}{l}\text { Investigar o impacto da variação } \\
\text { dos preços no risco sistêmico e } \\
\text { na volatilidade total da série. }\end{array}$ & $\begin{array}{l}\text { Os resultados mostram que tanto o risco sistêmico } \\
\text { como a volatilidade total dos retornos explicam, } \\
\text { parcialmente, as diferenças no cálculo do preço e que } \\
\text { o poder explicativo da volatilidade total é } \\
\text { incremental ao beta de mercado dos fatores } \\
\text { propostos por Fama e French (1992), ao tamanho da } \\
\text { firma e a proporção Market to book. }\end{array}$ \\
\hline $\begin{array}{l}\text { Garrod e Mramor } \\
(2004)\end{array}$ & $\begin{array}{l}\text { Desenvolver um modelo teórico } \\
\text { rigoroso que explique a relação } \\
\text { entre as medidas de risco e as } \\
\text { variáveis contábeis. }\end{array}$ & $\begin{array}{l}\text { Conclui a existência da capacidade de gerar um } \\
\text { modelo de previsão que utiliza medidas contábeis de } \\
\text { extensão mais robusta. }\end{array}$ \\
\hline $\begin{array}{l}\text { Elyasiani e Mansur } \\
(2005)\end{array}$ & $\begin{array}{l}\text { Estimar as sensibilidades de } \\
\text { mercado, taxas de juros e taxa de } \\
\text { câmbio (betas) das instituições } \\
\text { bancárias japonesas, bem como, } \\
\text { investigar a relação entre as } \\
\text { medidas de risco e índices } \\
\text { financeiros baseados em } \\
\text { Contabilidade. }\end{array}$ & $\begin{array}{l}\text { Os resultados indicam que a taxa de juros é apenas } \\
\text { ocasionalmente significativa, enquanto as variáveis } \\
\text { de mercado e taxa de câmbio são significativas para } \\
\text { todos os bancos. O beta de mercado e a taxa de } \\
\text { câmbio são medidas de risco com poder explicativo } \\
\text { do modelo de mercado. E a associação das medidas } \\
\text { de risco de mercado e os índices financeiros são mais } \\
\text { fracas para os bancos japoneses do que para os dos } \\
\text { EUA. }\end{array}$ \\
\hline Abdelghany (2005) & $\begin{array}{l}\text { Determinar quais variáveis } \\
\text { contábeis que devem ser } \\
\text { divulgadas como um substituto } \\
\text { do risco de mercado. }\end{array}$ & $\begin{array}{l}\text { Os resultados mostram que as empresas com maior } \\
\text { proporção do ativo circulante para o passivo } \\
\text { circulante tendem a ter um maior grau de risco de } \\
\text { mercado. }\end{array}$ \\
\hline $\begin{array}{l}\text { Brimble e Hodgson } \\
\text { (2007) }\end{array}$ & $\begin{array}{l}\text { Examinar a associação entre a } \\
\text { informação contábil e medidas } \\
\text { de risco sistêmico (beta) que } \\
\text { incorporam características } \\
\text { dinâmicas do mercado. }\end{array}$ & $\begin{array}{l}\text { Os resultados mostram uma forte associação entre as } \\
\text { variáveis contábeis (operacionais e de crescimento) } \\
\text { e risco sistêmico, sendo consistentes ao longo do } \\
\text { tempo, mas com algumas diferenças provocadas } \\
\text { pelo setor, tamanho e efeitos dos países. }\end{array}$ \\
\hline Hassan et al. (2011) & $\begin{array}{l}\text { Examinar a associação entre a } \\
\text { divulgação } \\
\text { voluntária e o risco sistêmico } \\
\text { para uma amostra de empresas } \\
\text { listadas egípcias. }\end{array}$ & $\begin{array}{l}\text { Os resultados mostram uma relação negativa entre o } \\
\text { nível de disclosure voluntário e beta. A principal } \\
\text { implicação destes achados é que a informação } \\
\text { voluntária sobre empresas listadas parece preferível, } \\
\text { a fim de reduzir o nível de risco percebido de uma } \\
\text { empresa. }\end{array}$ \\
\hline $\begin{array}{l}\text { Menéndez-Plans, } \\
\text { Orgaz e Prior } \\
(2012)\end{array}$ & $\begin{array}{l}\text { Determinar a relação entre } \\
\text { variáveis contábeis e indicadores } \\
\text { de eficiência e produtividade } \\
\text { com } \quad \text { o } \\
\text { macroeconômico. }\end{array}$ & $\begin{array}{l}\text { Os resultados mostram que há uma conexão entre as } \\
\text { variáveis e o risco, contudo, diferem de acordo com } \\
\text { as carteiras de mercado. Assim o risco de mercado é } \\
\text { explicado através da informação da Contabilidade, } \\
\text { análise de eficiência dos negócios e do ambiente } \\
\text { macroeconômico. }\end{array}$ \\
\hline $\begin{array}{l}\text { Amorim, Lima } \\
\text { Múrcia (2012) }\end{array}$ & $\begin{array}{l}\text { Analisar a relação entre os betas } \\
\text { contábeis e os betas de mercado } \\
\text { de companhias no Brasil. }\end{array}$ & $\begin{array}{l}\text { Evidenciou-se que alguns betas contábeis podem } \\
\text { explicar o beta de mercado e de forma antecipada, e } \\
\text { ainda, melhorar sua previsão quando associados aos } \\
\text { betas de mercado históricos. }\end{array}$ \\
\hline
\end{tabular}


Quadro 2 - Pesquisas do tema Risco x Informação contábil

\begin{tabular}{|c|c|c|}
\hline \multicolumn{3}{|c|}{ (Conclusão...) } \\
\hline $\begin{array}{l}\text { Papadamou e } \\
\text { Tzivinikos (2013) }\end{array}$ & $\begin{array}{l}\text { Estimar o risco de mercado, a } \\
\text { taxa de juro e câmbio de } \\
\text { instituições financeiras gregas; } \\
\text { explorar a relação entre as } \\
\text { medidas de risco baseadas em } \\
\text { variáveis contábeis e do } \\
\text { mercado, antes e depois da } \\
\text { adoção das IFRS e suas } \\
\text { alterações no conteúdo } \\
\text { informacional da Contabilidade. }\end{array}$ & $\begin{array}{l}\text { Os resultados revelam que todos os bancos estão } \\
\text { expostos ao risco de mercado. Além disso, a } \\
\text { introdução IFRS reforça a capacidade explicativa } \\
\text { dos dados contabilísticos, sobre os riscos sistêmico e } \\
\text { não sistêmico. Sobre o risco-relevância de índices } \\
\text { contábeis, medidas de liquidez, credibilidade, o } \\
\text { lucro por ação e as provisões para perdas de crédito } \\
\text { são inversamente proporcionais aos riscos sistêmico } \\
\text { e não sistêmico em IFRS. }\end{array}$ \\
\hline $\begin{array}{l}\text { Amorim, Lima e } \\
\text { Pimenta } \\
(2014)\end{array}$ & $\begin{array}{l}\text { Investigar se os betas contábeis } \\
\text { de uma empresa possuem } \\
\text { relação com seu risco sistêmico, } \\
\text { calculado como beta de } \\
\text { mercado. }\end{array}$ & $\begin{array}{l}\text { Constata-se a associação entre os betas contábeis e } \\
\text { de mercado, embora estas correlações tenham sido } \\
\text { mais fortes, na presença de variáveis como o Lucro } \\
\text { antes do Imposto de Renda, Market to Book, } \\
\text { Endividamento e Liquidez. }\end{array}$ \\
\hline
\end{tabular}




\section{METODOLOGIA}

\subsection{Modelo Econométrico}

\subsubsection{Definição do Universo e Amostra}

Desde 2001, quase 138 países requereram ou permitiram o uso das IFRS. O processo de convergência sob a responsabilidade do IASB tem se mostrado organizado e bem-sucedido. Atualmente, o IASB vem montando um perfil específico para cada país integrante do processo de convergências das práticas contábeis, sendo que 81 países já possuem seu perfil concluído e disponibilizado quanto às jurisdições individuais que fazem ou permitem o uso das IFRS. Eventualmente, se planeja ter um perfil para cada jurisdição que adotou as IFRS ou que está em um programa para a adoção (IFRSFOUNDATION, 2015).

Para esta pesquisa, dada a acessibilidade das informações, optou-se por ter, como amostra, as companhias de capital aberto com ações negociadas nas bolsas de valores no G7 (Grupo dos 7), ANZCERTA (Australia New Zealand Closer Economic Relations Trade Agreement) e no BRICS (Brazil, Russia, India, China, South Africa), incluindo-se, portanto, países de todos os continentes. Os bancos foram incluídos, uma vez que exercem uma participação importante no processo de convergência internacional das práticas contábeis, considerando que o sistema de regulação é essencial para o bom andamento do mercado financeiro.

O G7 foi tomado como referência, pois foi criado para facilitar a cooperação econômica entre as maiores industrias do mundo, países que, segundo o FMI (Fundo Monetário International), em relatório sobre o desempenho econômico das nações membros da instituição, são os maiores em termos de participação no PIB (Produto Interno Bruto) mundial e que, em projeção até 2018, essa participação tende a crescer (INTERNATIONAL..., 2013). A pesquisa de Wilson e Stupnytska (2007) realizou a projeção do PIB até 2050, destacando que todos os países que participam do G7 podem permanecer no top 10. Os membros do G7 são Canadá, França, Alemanha, Reino Unido, Itália, Japão e Estados Unidos.

Como forma de diversificar ainda mais a amostra, englobou-se também o grupo econômico ANZCERTA, fruto de um acordo entre dois países (Austrália e a Nova Zelândia), que assim como a maioria dos grupos econômicos, tiveram a intenção de criar uma área de livre comércio e tem aumentado o volume de relações comerciais australiano-neozelandezas em mais de $400 \%$. 
Os BRICS também foram incluídos na amostra, considerando ser um grupo que se destacava em termos de países emergentes e reúnem características que permitem que sejam tomados como um conjunto, estando esses em ascensão na economia mundial. $\mathrm{O}$ grupo tem sido responsável por uma parcela significativa do PIB mundial, em torno de 23\% (O'NEILL, 2001). Torres (2008) destaca que os BRICS lideram o grupo dos emergentes, tendo um potencial de desenvolvimento evidente. Os membros são Brasil, Rússia, Índia, China e África do Sul.

Foi então feita a análise, dentro do G7, do ANZCERTA e dos BRICS, de forma a selecionar os países que estão participando efetivamente do processo de convergência internacional das práticas contábeis (Ver Quadro 3).

Quadro 3 - Situação em Relação as Companhias Listadas nos países Participantes do G7, do BRICS e do ANZCERTA

\begin{tabular}{|l|l|}
\hline PAÍS PARTICIPANTE & SITUAÇÃO EM RELAÇÃO ÀS COMPANHIAS LISTADAS \\
\hline Canadá & $\begin{array}{l}\text { Requerido a partir de } 1^{\circ} \text { de Janeiro de } 2011 \text { para todas as entidades listadas, } \\
\text { incluindo organizações sem fins lucrativos }\end{array}$ \\
\hline França & $\begin{array}{l}\text { Requerido, desde } 2005, \text { para todas as informações consolidadas de todas as } \\
\text { entidades listadas }\end{array}$ \\
\hline Alemanha & $\begin{array}{l}\text { Requerido, desde 2005, para todas as informações consolidadas de todas as } \\
\text { entidades listadas }\end{array}$ \\
\hline Reino Unido & $\begin{array}{l}\text { Requerido, desde 2005, para todas as informações consolidadas de todas as } \\
\text { entidades listadas }\end{array}$ \\
\hline Itália & $\begin{array}{l}\text { Requerido, desde 2005, para todas as informações consolidadas de todas as } \\
\text { entidades listadas }\end{array}$ \\
\hline Japão & $\begin{array}{l}\text { Permitido a partir de 2010 para aplicações voluntárias nas informações } \\
\text { consolidadas de algumas entidades que atendem características específicas }\end{array}$ \\
\hline Estados Unidos & $\begin{array}{l}\text { Não permite aos emissores de valores mobiliários domésticos usarem IFRSs e } \\
\text { não obriga os emissores estrangeiras usarem }\end{array}$ \\
\hline Brasil & $\begin{array}{l}\text { Requeridos para todas as companhias listadas e da maior parte das instituições } \\
\text { financeiras não listadas, tanto para as informações consolidadas como para as } \\
\text { individuais. Houve uma conversão parcial desde 2008 e total desde 2010. }\end{array}$ \\
\hline Rússia & Requerido para todas as entidades, a partir de 2012. \\
\hline Índia & Não adotou IFRSs. \\
\hline China & Pronunciamentos convergidos com os IFRS desde 2007. \\
\hline África do Sul & Requerido para companhias listadas desde 2005 \\
\hline Nova Zelândia & Requerido para companhias listadas desde 2007 \\
\hline Austrália & Requerido para todas as entidades, a partir de 2005. \\
\hline Fonte: IFRS FOUNDATION & 2015 ) \\
\hline
\end{tabular}

Fonte: IFRS FOUNDATION (2015)

Assim, depreende-se do Quadro 3, que foram excluídos da amostra os países que ainda não requerem (exigem) a utilização das IFRS, assim como aqueles que não realizaram a exigência de adesão às normas internacionais em tempo oportuno de ser possível realizar a investigação do impacto antes e depois da adoção. Portanto, a amostra deste trabalho foi composta pelos seguintes países: Canadá; França; Alemanha; Reino Unido; Itália; Brasil; Rússia; China; África do Sul; Nova Zelândia e Austrália. 


\subsubsection{Estimação do Beta e Estatística Descritiva}

Para a estimação dos Betas dinâmicos dos mercados, foram coletados os índices de mercado principais dos 11 países estabelecidos como amostra. Os índices de mercado são ponderados no sentido de se ter índices de pesos iguais, pois eles são proxies superiores à verdadeira carteira de mercado (BRADFIELD, 2003).

O período pesquisado inicia em Janeiro de 2000 e vai até setembro de 2015. Considerando que a pesquisa envolve o mercado de capitais de países distintos, os quais apresentam diferenças quanto aos dias de negociação, optou-se por utilizar dados mensais (último dia do mês).

O retorno composto em dólar (americano) será estimado através da equação 3.

$$
r_{i t}=\ln \left(P_{i, t} / E_{i, t}\right)-\ln \left(P_{i, t-1} / E_{i, t-1}\right)
$$

Em que, $r_{i t}$ é o retorno do ativo i no tempo t. Seja $P_{i, t}$ o preço do ativo i no período t e $P_{i, t-1}$ o preço do ativo i no período t-1. $E_{i, t}$ é a taxa de câmbio média comercial no tempo t e

$E_{i, t-1}$ é a taxa de câmbio comercial no tempo t-1. O retorno composto continuamente é obtido entre o período $\mathrm{t}-1$ e $\mathrm{t}$.

Seguindo a ótica de Ng (2004), foram estimados os Betas dinâmicos dos mercados, através do modelo GARCH (Generalized Autoregressive conditional heterocedasticity) Multivariado, desenvolvido por Susmel e Engle (1994). Esse modelo faz parte de uma família de modelos estatísticos originalmente desenvolvidos por Engle (1982) e Engle e Bollerslev (1986). A escolha do modelo se deu pela sua capacidade de capturar as mudanças nos retornos, além de estimar a variância condicional da série.

$\mathrm{Ng}$ (1991) foi uma das pioneiras em realizar um teste do CAPM na abordagem GARCH Multivariado, verificando se a proxy do portfólio de mercado está na fronteira da médiavariância condicional. Assim, a matriz de covariância condicional de retorno dos ativos é assumida para seguir um processo ARCH (Autoregressive conditional heterocedasticity) generalizado $(\mathrm{GARCH})$ multivariado com a matriz de correlação condicional dos retornos dos ativos (relação entre o prêmio de risco e sua variância) sendo constante ao longo do tempo.

O GARCH Multivariado permite, então, que os excessos de retornos condicionais, as variâncias condicionais e as covariâncias condicionais mudem ao longo do tempo (NG, 1991). 
A abordagem seguida foi a de Tse e Tsui (2002), na qual se explora o método a partir da estimação dos Betas dinâmicos da covariância condicional e variância condicional obtida. $\mathrm{O}$ modelo de MGARCH (Multivariate GARCH) trabalhado por Tse e Tsui (2002) é um aperfeiçoamento do modelo de Bollerslev, Engle e Wooldridge (1988) e do modelo de Engle e Kroner (1995).

O software estatístico utilizado para a estimação do Beta foi o Matlab, que se utiliza do modelo MGARCH para realizar o cálculo do Beta. Inicialmente, o programa Matlab organizou os dados seguindo a sequência dos índices utilizados conforme o Quadro 4.

Os dados acerca dos índices foram coletados a partir do Yahoo Finance que é um provedor gratuito de cotações internacionais. O índice é um indicador de desempenho de uma seleção de ações, sendo termômetros para os mercados. Além dos índices principais de cada país foi utilizado o MSCI (Morgan Stanley Capital International), que é um índice mundial, aceito pela atividade do mercado de capitais de forma global. O MSCI é composto por fontes de retornos de firmas de 46 mercados desenvolvidos e emergentes, fornecendo uma visão sem viés, moderna e totalmente integrada dos mercados participantes (MSCI, 2015).

Quadro 4 - Sequência estabelecida para o Cálculo dos Betas segundo os índices dos países

\begin{tabular}{|c|c|c|c|}
\hline Código & País & Índice & Ticker \\
\hline 1 & & MSCI & Índice Mundial \\
\hline 2 & Austrália & S\&P/ASX 200 \\
\hline 3 & Brasil & Ibovespa Brasil Sao Paulo Stock Exchange Index & IBOV \\
\hline 4 & China & Shangai Stock Exchange Composite Index & SHCOMP \\
\hline 5 & Canadá & S\&P/TSX Composite Index & SPTSX \\
\hline 6 & Alemanha & Deutsche Borse AG German Stock Index DAX & DAX \\
\hline 7 & Reino Unido & Financial Times Stock Exchange 100 Index & UKX \\
\hline 8 & Itália & Financial Times Stock Exchange MIB Index & FTSEMIB \\
\hline 9 & França & Cotation Assistée em Continu 40 & NAC40 \\
\hline 10 & Nova Zelândia & S\&P/NZX 50 Index & RTSI \\
\hline 11 & Rússia & Russia Trading System Index & JALSH \\
\hline 12 & África do Sul & FTSE/Johannesburg Stock Exchange & \\
\hline
\end{tabular}

Fonte: Yahoo Finance (2016)

O MGARCH é um modelo dinâmico, trabalhado através de dados mensais, no qual, para cada mês, calcularam-se as variâncias e as covariâncias condicionais, de modo a alcançar os retornos (conforme especificado no parágrafo seguinte). Os cálculos dos retornos tomaram como base o índice mundial MSCI e o índice de cada país (Ver Quadro 4), para, então, chegar na estimação do Beta conforme detalhamento a seguir: 
Considerando $r_{t}, t=1, \ldots, T$ o conjunto de observações multivariadas de retornos excedentes de índice de ações medidos em moeda de referência e do índice MSCI, cada um com $\mathrm{K}$ elementos, onde $r_{t}=\left(r_{1 t}, \ldots, r_{1} K T\right)$. A variância condicional, assumindo que $r_{t}$ varia no tempo, é determinada na Equação 4.

$$
\operatorname{Var}\left(r_{t} \mid \Phi_{t-1}\right)=\Omega_{t}
$$

Em que, $\Phi_{t}$ é o conjunto de informação no tempo t. A variância dos elementos $\Omega_{t}$ é representada por $\sigma_{1 t}$, para $i=1, \ldots, K$ e as covariâncias são demonstradas por $\sigma_{i j t}$, para $1 \leq$ $j \leq K$. Considerando que $D_{t}$ é uma matriz diagonal em que o elemento ith é $\sigma_{i j t}$, pode-se definir $\varepsilon_{t}=D_{t}^{-1} r_{t} \cdot \varepsilon_{t}$ representa o resíduo padronizado, assumindo-se ser Independent and identially distributed com média zero e matriz variância $\Gamma_{t}=\left\{\rho_{i j t}\right\}$. A matriz de correlação para $r_{t}$ é dada por $\Omega_{t}=D_{t} \Gamma_{t} D_{t}$. A variância condicional segue a formulação vech-diagonal de Bollerslev, Engle e Wooldridge (1988). Isto posto, cada termo da variância condicional segue um processo GARCH $(\mathrm{p}, \mathrm{q})$ univariado visualizado na Equação 5.

$$
\sigma_{i t}^{2}=\omega_{i}+\sum_{h=1}^{q} \alpha_{i h} r_{i, t-h}^{2}+\sum_{h=1}^{p} \beta_{i h} \sigma_{i, t-h}^{2}
$$

Em que, $\omega_{i}, \alpha_{i h}, \beta_{i h}$ são não negativos e $\sum_{h=1}^{q} \alpha_{i h}+\sum_{h=1}^{p} \beta_{i h}<1$ para todo $i=$ $1, \ldots, K$. A correlação condicional segue o processo descrito na Equação 6.

$$
\Gamma_{t}=\left(1-\theta_{1}-\theta_{2}\right) \Gamma+\theta_{1} \Gamma_{t-1}+\theta_{2} \Psi_{t-1}
$$

Em que, $\Gamma=\left\{\rho_{i j t}\right\}$ é uma matriz positiva definida com parâmetros de tamanho $K x K$, variante no tempo com elementos unitários na diagonal e $\Psi_{t-1}$ na qual os elementos são função das observações passadas de $r_{t}$. Os parâmetros $\theta_{1}$ e $\theta_{2}$ são não negativos e assume-se a restrição de que $\theta_{1}+\theta_{2} \leq 1$. 
Observa-se que $\Psi_{t-1}$ é análogo $r_{t-1}^{2}$ do $\operatorname{GARCH}(1,1)$. Entretanto, como $\Gamma_{t}$ é, na ótica de Tse e Tsui (2002), uma medida padronizada, $\Psi_{t-1}$ necessita depender do resíduo padronizado defasado $\varepsilon_{t}$. Defina $\Psi_{t}=\left\{\psi_{i j t}\right\}, \Psi_{t-1}$ seguindo a especificação definida na Equação 7.

$$
\psi_{i j, t-1}=\frac{\sum_{h=1}^{M} \varepsilon_{i, t-h} \varepsilon_{j, t-h}}{\sqrt{\left(\sum_{h=1}^{M} \varepsilon_{i, t-h} \sum_{h=1}^{M} \varepsilon_{j, t-h}\right)}}
$$

$\psi_{i j, t-1}$ é a matriz de correlação de $\varepsilon_{t-1}, \ldots, \varepsilon_{t-M}$. Defina $E_{t-1}$ uma matriz $K x M$ dado por $E_{t-1}=\left\{\varepsilon_{t-1}, \ldots, \varepsilon_{t-M}\right\}$. Se $B_{t-1}$ é uma matriz diagonal $K x K$ onde o ith elemento diagonal é $\left(\sum_{h=1}^{M} \varepsilon_{i, t-h}\right)^{1 / 2}$ para $i=1, \ldots, k$, tem-se a Equação 8 .

$$
\Psi_{t-1}=B_{t-1}^{-1} E_{t-1} E_{t-1}^{\prime} B_{t-1}^{-1}
$$

A função de máxima verossimilhança $\ell_{t}$ der $r_{t}$ é dada nas Equações 9 e 10.

$$
\begin{gathered}
\ell_{t}=\frac{1}{2} \ln \left|D_{t} \Gamma_{t} D_{t}\right|-\frac{1}{2} r^{\prime}{ }_{t} D_{t}^{-1} \Gamma_{t}{ }^{-1} D_{t}^{-1} r_{t} \\
\ell_{t}=\frac{1}{2} \ln \left|\Gamma_{t}\right|-\frac{1}{2} \sum_{i=1}^{K} \ln \sigma_{i t}^{2} \frac{1}{2} r^{\prime}{ }_{t} D_{t}^{-1} \Gamma_{t}{ }^{-1} D_{t}^{-1} r_{t}
\end{gathered}
$$

Considera-se $\theta=\left(\omega_{1}, a_{11}, \ldots, a_{1 q}, b_{11} \ldots, b_{1 p}, \omega_{2}, \ldots, a_{k q}, \rho_{12}, \ldots, \rho_{k-1}, k, \theta_{1}, \theta_{2}\right)$ o vetor de parâmetros do modelo os estimadores de máxima verossimilhança $\hat{\theta}$ são obtidos maximizando $\ell$ em relação a $\theta$.

Em síntese, as estimações do Beta provêm da covariância do índice MSCI com o índice do país dividido pela variância do índice MSCI. 
No intuito de resumir os dados e destacar valores de mesma natureza foi realizada a estatística descritiva, almejando que essa proporcione uma visão global da amostra estudada. As medidas descritivas utilizadas foram: Medidas de tendência central (restringindo-se a média e a mediana), medidas de dispersão (restringindo-se aos valores mínimo, máximo, amplitude, desvio-padrão e o coeficiente de variação). Essas medidas foram, então, utilizadas para que se pudesse apontar as diferenças entre os grupos estudados.

Foi feita a Matriz de Correlação dos Betas Estimados entre os países. Para a Correlação, foi tomado como base o Coeficiente de Correlação Linear $(r)$, também conhecido como coeficiente de Pearson, que é uma medida numérica da força ou o grau de associação linear entre duas variáveis que representam dados quantitativos. A intensidade da relação linear é então medida entre os valores quantitativos emparelhados " $x$ " e " $y$ " em uma amostra (GUJARATI; PORTER, 2011). A ser visto na equação 11.

$$
r=\frac{\sum_{i=1}^{n}\left(X_{i}-\bar{X}\right)\left(Y_{i}-\bar{Y}\right)}{(n-1) S_{x} S_{y}}
$$

Em que, $\bar{X}$ e $\bar{Y}$ são as médias de $X$ e $Y$, respectivamente. E, $S_{x}$ e $S_{y}$ são os desvios padrão de $X$ e $Y$, respectivamente.

Designada no software estatístico Matlab, consistiu então em uma matriz bidimensional correlacionando as diversas variáveis entre si.

Dessa forma, o Beta estimado para cada país foi testado em termos de reação linear entre os valores quantitativos emparelhados. Nessa linha, em algum momento, $x$ foi, por exemplo, o Beta estimado para o Brasil e y o Beta estimado para o Canadá e assim sucessivamente.

A medição da correlação leva em consideração o grau de dispersão entre os valores dos dados. Quanto menos dispersos estiverem os dados, mais forte será a relação (correlação) entre as duas variáveis. $\mathrm{O}$ valor de $r$ deve sempre estar entre $-1 \mathrm{e}+1$.

De acordo com Callegari-Jacques (2003), uma vez determinada a existência da correlação, é possível avaliá-la qualitativamente quanto à intensidade, conforme a Tabela 1. 
Tabela 1 - Avaliação Qualitativa do Grau de Correlação entre Duas Variáveis

\begin{tabular}{cc}
\hline$|r|$ & A correlação é dita \\
\hline 0 & Nula \\
$0-0,3$ & Fraca \\
$0,3-0,6$ & Regular \\
$0,6-0,9$ & Forte \\
$0,9-1$ & Muito Forte \\
1 & Plena ou Perfeita \\
\hline
\end{tabular}

Fonte: Callegari-Jacques (2003, p. 90)

\subsubsection{Regressão Quantílica}

Os cálculos tradicionais de probabilidades realizados pelo mercado financeiro não se sustentam dentro de uma curva normal, também conhecida como curva Gaussiana, uma vez que se trabalha com negociações de alta frequência.

A curva Gaussiana descreve eventos que oscilam em torno da média, assim quando as concentrações de dados se movem com os pontos muito próximos, significa que está tudo correndo dentro da normalidade. No entanto, fatos estranhos podem afetar essa normalidade o que, no mercado financeiro, é considerado comum, pois os investidores modificam a distribuição conforme o acesso às informações.

$\mathrm{Na}$ realidade, a hipótese da normalidade se mostrou bastante restritiva para mercados voláteis, ou seja, o mercado financeiro em si. Efeitos como curtose e assimetria da distribuição não devem ser desprezados, uma vez que geram grandes distorções entre os eventos ocorridos e os resultados dos modelos. Li, Sun e Zou (2009) colocam que ambiguidades encontradas nos resultados de pesquisas recentes se deve, em grande parte, à utilização inadequada do método dos mínimos quadrados.

Diante disso, quando a distribuição de erros se desvia da normalidade, o estimador de regressão quantílica pode ser mais eficiente do que o OLS (BUCHINSKY, 1998). Assim, a regressão quantílica é mais apropriada, pois permite examinar toda a distribuição de variáveis, sendo possível avaliar a importância das variáveis explicativas em diferentes pontos da distribuição (LI; SUN; ZOU, 2009).

O método de regressão quantílica foi proposto, pela primeira vez, por Koenker e Bassett Júnior (1978). Este método permite que o efeito de um regressor possa diferir em diferentes pontos da distribuição condicional da variável dependente e, deste modo, sendo capaz de detectar a variação da sensibilidade do desempenho de uma empresa para a proporção de propriedade de estado, entre os principais quantis da sua distribuição de desempenho. As 
estimativas da regressão quantílica são consideradas robustas em comparação com as estimativas ineficientes produzidas por mínimos quadrados padrão (BUCHINSKY, 1998).

\begin{abstract}
Uma fotografia mais completa do relacionamento poderia ser extraída se o regressando e os regressores fossem mostrados em diferentes pontos da distribuição condicional de y. A regressão quantílica é um instrumento estatístico para construção de tal fotografia. Na verdade, a regressão quantílica produz estimativas aproximadas de qualquer quantil da distribuição condicional de y, não apenas da média.
\end{abstract}

A técnica da regressão quantílica permite analisar a associação entre a variável resposta (Beta) com a variável explicativa (Dummy da presença e ausência das IFRS) nos diversos quantis da distribuição condicional. Dessa forma, consegue-se uma representação mais característica do impacto da presença/ausência das IFRS sobre o Beta (risco). Consegue-se investigar como o quantil responde, em vez de se ter somente uma reta de regressão.

O estimador de regressão quantilica é derivado através da minimização de uma soma ponderada dos desvios absolutos, as estimativas dos parâmetros são menos sensíveis aos outliers e caudas longas na distribuição de dados. Isso faz com que o estimador de regressão quantílica seja relativamente robusto para a heteroscedasticidade dos resíduos (LI; SUN; ZOU, 2009).

Uma investigação explicita desses efeitos, via regressão quantílica, pode prover uma visão mais detalhada do relacionamento aleatório entre as variáveis e, desta forma, uma análise informativa melhor.

O conjunto de dados foi organizado e empilhado com todas as companhias listadas nos 11 países participantes da amostra, segregando o período do pré e pós adoção das IFRS por ano. O Beta antes exposto de forma mensal, como aqui já foi destacado, foi também trabalhado de forma anual, utilizando-se a média dos dados mensais. Os dados foram processados no software EViews $^{\circledR} 8$.

A equação de Risco em estudo assume, primeiramente, a forma funcional descrita na Equação 12.

$$
\text { Beta }_{i}=\beta_{0}+\beta_{1} \text { Dummy }_{i}+\varepsilon_{i}
$$

Em que, Beta é o Beta dinâmico estimado e a Dummy é variável binária que assume "0" para o período de tempo em que não há presença das IFRS e "1" para o período de tempo em que há presença das IFRS. 
O conceito de Risco Sistêmico, embora aqui, dado limitações para se realizar pesquisas empíricas tenha sido tratado de forma específica, é bastante amplo, de forma que, o risco de mercado é influenciando por uma série de fatores, tais quais: variações nas taxas de juros e taxas de câmbio, inflação, crises políticas, crises financeiras, entre outras. Dessa forma, no sentido de se investigar se tais fatores mudam o contexto investigado e restrito ao fator IFRS, em seguida, a equação de Risco em estudo assume a forma funcional da Equação 13.

$$
\text { Beta }_{i}=\beta_{0}+\beta_{1} \text { Dummy }_{i}+\beta_{1} T C_{i}+\beta_{1} T J_{i}+\varepsilon_{i}
$$

Em que, Beta é o Beta dinâmico estimado; a Dummy é variável binária que assume "0" para o período de tempo em que não há presença das IFRS e "1" para o período de tempo em que há presença das IFRS; TC é referente à Taxa de Câmbio; e TJ remete à Taxa de Juros.

Os dados de Taxas de Juros e Taxas de Câmbio foram coletados na Reuters $^{\circledR 2}$, sendo buscados de forma mensal de 2000 a 2014. A maioria dos países foram apresentados por títulos, tendo sido usada a média daqueles para os quais havia observações para todos os períodos.

O valor da curtose da variável Beta (variável dependente) não se trata de uma distribuição normal, onde a curtose é igual a 0 . No geral, as distribuições são maiores que 0 , de modo que tem uma distribuição afunilada, com caudas pesadas. Para os casos que a curtose da variável Beta foi menor que 0, a distribuição é mais achatada que a distribuição normal. Assim, a distribuição não segue a curva normal, reforçando a escolha pelo uso do método de regressão quantílica.

Dessa forma, justifica-se o uso da regressão quantílica, pois capta os efeitos da variável ao longo da distribuição, de acordo com quantis adequadamente selecionados. Além disso, a vantagem da quantílica é a possibilidade de avaliar fenômenos que apresentam discrepâncias com mais precisão, como é o caso dos diferentes países em estudo.

A regressão quatílica seria uma extensão natural dos quantis amostrais para o caso de um modelo linear $\mathrm{y}_{t}=\mathrm{X}_{t} \beta+\varepsilon_{t}$, o qual assume a forma da Equação 14 .

\footnotetext{
2 ®2016 Thomson Reuters
} 


$$
\begin{aligned}
& \min _{b \in \Re} \mathrm{n}^{-1}\left\{\sum_{\mathrm{t} \in\left\{\mathrm{t}: \mathrm{y}_{\mathrm{t}} \geq \mathrm{x}_{\mathrm{t}} \beta\right\}} \theta\left|\mathrm{y}_{\mathrm{t}}-\mathrm{x}_{\mathrm{t}} \beta\right|+\sum_{\mathrm{t} \in\left\{\mathrm{t}: \mathrm{y}_{\mathrm{t}}<\mathrm{x}_{\mathrm{t}} \beta\right\}} 1-\theta\left|\mathrm{y}_{\mathrm{t}}-\mathrm{x}_{\mathrm{t}} \beta\right|\right\} \\
& =\min ^{-1} \sum_{\mathrm{i}=1}^{\mathrm{n}} \rho_{\theta}\left(\mathrm{y}_{\mathrm{t}}-\mathrm{x}_{\mathrm{t}} \beta\right)
\end{aligned}
$$

Em que $\rho$ é a função “check” definida na Equação 15.

$$
\rho_{\theta}(u)=\left\{\begin{array}{cc}
\theta u & u \geq 0 \\
(\theta-1) u, & u<0
\end{array}\right.
$$

\subsubsection{Análise Fatorial}

A análise fatorial "é uma abordagem estatística que pode ser usada para analisar interrelações entre um grande número de variáveis e explicar essas variáveis quanto a suas dimensões inerentes comuns (fatores)" (HAIR JÚNIOR et al., 2009, p. 33).

Foram selecionadas variáveis contábeis consideradas de interesse do investidor e que possivelmente têm relação com o risco de se investir em um determinado ativo, podendo modificar o processo decisório (Ver Quadro 5). “A qualidade e o significado dos fatores obtidos refletem as bases conceituais das variáveis incluídas na análise" (HAIR JÚNIOR et al., 2009, p. 106).

A maioria das variáveis contábeis aqui utilizadas já foram empregadas em outras pesquisas envolvendo risco (HILL; STONE, 1980; CHUN; RAMASAMY, 1989; LAVEREN et al., 1997; CAPELLETTO, 2006; AMORIM; LIMA; MURCIA, 2012; AMORIM; LIMA; PIMENTA JÚNIOR, 2014). 
Quadro 5 - Variáveis Contábeis

(Continua...)

\begin{tabular}{|c|c|c|c|}
\hline Cód & SIGLA DA VARIÁVEL & NOME DA VARIÁVEL & DETALHAMENTO \\
\hline 1 & PX_TO_BOOK_RATIO & Price/Book Value & $\begin{array}{l}\text { Relação do preço da ação e do valor contábil } \\
\text { por ação }\end{array}$ \\
\hline 2 & EBIT & LAIR & Os lucros antes dos juros e impostos \\
\hline 3 & PX_LAST & Último preço ação & O último preço do ativo \\
\hline 4 & EBITDA & EBITDA & $\begin{array}{l}\text { Lucros antes de juros, taxas, depreciação e } \\
\text { amortização (EBITDA) }\end{array}$ \\
\hline 5 & BS_TOT_ASSET & Ativo Total & $\begin{array}{l}\text { Total de todos os ativos de curto e longo } \\
\text { prazo }\end{array}$ \\
\hline 6 & BS_TOT_LIAB2 & Passivo Total & $\begin{array}{l}\text { Total de todos os passivos de curto e longo } \\
\text { prazo }\end{array}$ \\
\hline 7 & ENTERPRISE_VALUE & Valor da Empresa & $\begin{array}{l}\text { Medida do preço teórico de aquisição de uma } \\
\text { empresa. Capitalização de mercado }+ \\
\text { Componentes do valor corrente }\end{array}$ \\
\hline 8 & NET_INCOME & Lucro Líquido & $\begin{array}{l}\text { Lucro (prejuízo) líquido: O lucro após a } \\
\text { dedução de todas as despesas. }\end{array}$ \\
\hline 9 & SALES_REV_TURN & Revenues & $\begin{array}{l}\text { Vendas/Receita/Giro: Total de receitas } \\
\text { operacionais menos ajustes variados em } \\
\text { Vendas brutas. Ajustes: Retornos, descontos, } \\
\text { provisões, tributos retidos, encargos de } \\
\text { seguro, impostos sobre vendas e impostos } \\
\text { sobre valor agregado. }\end{array}$ \\
\hline 10 & IS_OPER_INC & Lucro Operacional & $\begin{array}{l}\text { Lucro (prejuízo) operacional: Vendas líquidas } \\
+ \text { Outros lucros operacionais - Custo de bens } \\
\text { vendidos - Outros prejuízos operacionais. }\end{array}$ \\
\hline 11 & CF_FREE_CASH_FLOW & Free Cash Flow & $\begin{array}{l}\text { Fluxo de caixa de atividades operacionais } \\
\text { menos o total de despesas de capital. Despesa } \\
\text { de capital é a quantia que a empresa gastou na } \\
\text { compra de imobilizados tangíveis. }\end{array}$ \\
\hline 12 & IS_EPS & Basic EPS & $\begin{array}{l}\text { Lucros por Ação: Inclui os efeitos de todos os } \\
\text { ganhos/perdas únicos, não recorrentes e } \\
\text { extraordinários. Utiliza a Média Ponderada } \\
\text { Básica de Ações, excluindo os efeitos de } \\
\text { conversíveis. }\end{array}$ \\
\hline 13 & TOTAL_EQUITY & Patrimônio Líquido & Ativo total da empresa menos o passivo total. \\
\hline 14 & IS_INC_TAX_EXP & IR+CSLL & Despesas do imposto de renda. \\
\hline 15 & BS_CUR_LIAB & Passivo Circulante & $\begin{array}{l}\text { Passivos circulantes: A soma de passivos de } \\
\text { curto prazo. }\end{array}$ \\
\hline 16 & $\begin{array}{l}\text { SHORT_AND_LONG_TER } \\
\text { M_DEBT }\end{array}$ & $\begin{array}{l}\text { Dívida Onerosa: } \\
\text { Empréstimos e } \\
\text { Financiamentos }\end{array}$ & $\begin{array}{l}\text { Soma da dívida de curto prazo e Dívida de } \\
\text { longo prazo. }\end{array}$ \\
\hline 17 & PX_VOLUME & $\begin{array}{l}\text { Volume comercial de } \\
\text { transações }\end{array}$ & Volume comercial de ações negociadas \\
\hline 18 & RETURN_COM_EQY & $\begin{array}{l}\text { ROE - Retorno sobre o } \\
\text { Patrimônio Líquido }\end{array}$ & $\begin{array}{l}\text { O retorno do patrimônio (em porcentagem) é } \\
\text { calculado como a renda líquida de } 12 \text { meses } \\
\text { consecutivos (perdas) menos os dividendos } \\
\text { preferenciais do caixa de } 12 \text { meses } \\
\text { consecutivos, dividido pela média do total do } \\
\text { patrimônio comum, multiplicado por } 100 \text {. }\end{array}$ \\
\hline 19 & RETURN_ON_ASSET & $\begin{array}{l}\text { ROA - Retorno sobre o } \\
\text { Ativo }\end{array}$ & $\begin{array}{l}\text { Retorno de ativos (ROA, em porcentagem): } \\
\text { (Receita líquida dos últimos } 12 \mathrm{M} / \text { Média } \\
\text { total de ativos) } * 100\end{array}$ \\
\hline
\end{tabular}




Quadro 5 - Variáveis Contábeis
\begin{tabular}{|l|l|l|l|}
\hline Cód & SIGLA DA VARIÁVEL & NOME DA VARIÁVEL & \multicolumn{1}{c|}{ DETALHAMENTO } \\
\hline 20 & $\begin{array}{l}\text { VALUE_ADDED_INTERES } \\
\text { T_ON_CAPITAL }\end{array}$ & $\begin{array}{l}\text { Juros sobre o capital } \\
\text { próprio }\end{array}$ & $\begin{array}{l}\text { Juros sobre o capital próprio: valores pagos } \\
\text { ou creditados aos parceiros e acionistas que } \\
\text { não se deram através de dividendos, exceto os } \\
\text { valores transferidos para reservas de lucros. } \\
\text { Inclui apenas os valores distribuídos com } \\
\text { base no resultado do período. }\end{array}$ \\
\hline 21 & WORK_CAP_GROWTH & Capital de giro & $\begin{array}{l}\text { Capital de giro = Ativo circulante - Passivo } \\
\text { circulante. } \\
\text { (Capital de giro (período corrente) - Capital } \\
\text { de giro (período anterior)) X 100 }\end{array}$ \\
\hline 22 & $\begin{array}{l}\text { ARD_TOTAL_FINANCIAL_ } \\
\text { LOSSES }\end{array}$ & Despesas Financeiras & $\begin{array}{l}\text { Total de perdas financeiras conforme } \\
\text { divulgado pela empresa. }\end{array}$ \\
\hline 23 & BS_CUR_ASSET_REPORT & Ativo Circulante & Total dos ativos de curto prazo. \\
\hline 24 & BS_NET_FIX_ASSET & Ativo Imobilizado & Total dos ativos fixos. \\
\hline 25 & CF_CASH_FROM_OPER & Operating Cash Flow & $\begin{array}{l}\text { Valor total do fluxo de caixa gerado pelas } \\
\text { operações de uma empresa. }\end{array}$ \\
\hline 26 & APPLIED_BETA & Beta do Ativo & $\begin{array}{l}\text { Variação percentual no preço de uma ação } \\
\text { dada a variação de um percentual no índice } \\
\text { de benchmark. }\end{array}$ \\
\hline
\end{tabular}

Fonte: Bloomberg (®2016 Bloomberg L.P.)

Buscou-se o máximo de variáveis contábeis possíveis, no sentido de investigar sua relação com o risco e, conforme pode ser visto no Quadro 5, se usou a nomenclatura da plataforma de dados Bloomberg Professional ${ }^{\circledR 3}$, no qual foram coletados os dados, e se enfatizou o detalhamento também encontrado nela para contextualizar as contas que compõem cada uma das variáveis. Utilizaram-se os dados anuais e o período pesquisado se iniciou em 2000 e foi até 2014. Não se optou por separar as empresas por setores, dado o sentido de a adoção de normas internacionais de Contabilidade abranger todos títulos negociados pelas empresas de todos os setores. Assim, para cada ano, obteve-se em torno de 14.000 títulos para cada variável contábil em cada país que compõe a amostra; dessa forma, obteve-se a média anual de todas as empresas.

Assim, foi utilizada a técnica de análise fatorial por ser uma técnica multivariada de interdependência, de forma que o interesse não é classificar uma variável como dependente ou independente, mas analisar, simultaneamente, todas as variáveis, de forma a encontrar uma estrutura subjacente a todo o conjunto de variáveis.

Assim, o objetivo da análise fatorial é a parcimônia, trabalhando de forma geral com a ideia de relacionar as variáveis de modo simples, buscando a melhor relação entre elas. A análise fatorial, portanto, mostra-se adequada, pois trabalha-se com o pressuposto de que existe alguma estrutura subjacente no conjunto de variáveis escolhidas (HAIR JÚNIOR et al., 2009).

\footnotetext{
3 ®2016 Bloomberg L.P.
} 
Desta forma, considerando uma matriz de correlação para um conjunto de variáveis, a Análise Fatorial permitiu investigar a existência de algum padrão de relacionamento entre as variáveis, o qual conduziu à redução dos dados em um pequeno conjunto de fatores, não sacrificando as informações (no sentido de variabilidade) contidas nas variáveis originais.

Assim, foi utilizada a análise fatorial $R$, "que analisa um conjunto de variáveis para identificar as dimensões latentes" (HAIR JÚNIOR et al., 2009, p. 104). Foi utilizada a análise fatorial exploratória, que é aplicada quando não se tem uma ideia pré-definida da estrutura e de quantas dimensões estão presentes em um conjunto de variáveis. Dessa forma, para a obtenção de fatores, usou-se a análise de componentes principais que contempla a variância total dos dados.

A análise fatorial deve atender a alguns requisitos, os quais são medidos por testes específicos. Entre esses testes tem-se a análise da matriz de correlação antiimagem que tem, como intuito, obter sinais da necessidade da retirada de alguma variável do modelo que, porventura, não esteja contribuindo para uma melhor explicação do modelo. A diagonal principal da matriz antiimagem fornece o MSA (Measure of Sampling Adequacy), seu valor varia entre 0 e 1 , mas, para uma boa adequação do modelo, de forma que a variável seja perfeitamente prevista sem erros pelas demais variáveis, deve ser superior a 0,5 (HAIR JÚNIOR et al., 2009). A ideia é buscar o conjunto mais parcimonioso das variáveis em estudo.

Outro teste é o KMO (Kaiser-Meyer-Olkin), que mede o grau da correlação parcial entre as variáveis (MSA). O quociente mais próximo a 1 indica dados adequados e maior benefício na utilização da análise fatorial (BEZERRA, 2009; HAIR JÚNIOR et al., 2009) (Ver Tabela 2).

Tabela 2 - Medida de Adequação da Amostra (KMO-MSA)

\begin{tabular}{ll}
\hline MSA $\geq 0,80$ & Admirável \\
$M S A \geq 0,70$ e $<0,80$ & Mediano \\
$M S A \geq 0,60$ e $<0,70$ & Medíocre \\
MSA $\geq 0,50$ e $<0,60$ & Ruim \\
MSA $<0,50$ & Inaceitável \\
\hline
\end{tabular}

Fonte: HAIR JÚNIOR et al. (2009).

O teste de esfericidade de Bartlett (Bartlett Test of Sphericity) "fornece a significância estatística de que a matriz de correlação tem correlações significantes entre pelo menos algumas das variáveis" (HAIR JÚNIOR et al., 2009, p. 110). Nesse caso, demonstra-se que apenas alguns fatores podem ser suficientes para representar a maior parte da variabilidade dos dados. Existirá a possibilidade de utilizar a técnica de Análise Fatorial quando é possível rejeitar que não há correlação entre as variáveis ao nível de significância estipulado. Se a significância 
apresentada pelo teste for menor ou igual a 0,05 rejeita-se a hipótese e, portanto, a técnica é adequada (BEZERRA, 2009; HAIR JÚNIOR et al., 2009).

Segundo Bezerra (2009, p. 79), o modelo matemático é descrito na Equação 16.

$$
X_{i}=\alpha_{i 1} F_{1}+\alpha_{i 2} F_{2}+\alpha_{i 3} F_{3}+\cdots+\alpha_{i j} F_{1}+e_{i}
$$

\begin{abstract}
Em que, $X_{i}$ são as variáveis padronizadas, $\alpha_{i}$ são as cargas fatoriais, $F_{j}$ são os fatores comuns não relacionados entre si e o $e_{i}$ é um erro que representa a parcela da variação da variável $\boldsymbol{i}$ que é exclusiva dela e não pode ser explicada por um outro fator nem por outra variável do conjunto analisado. As cargas fatoriais são valores que medem o grau de correlação entre a variável original e os fatores.
\end{abstract}

Assim, a intenção de se utilizar o método de análise fatorial foi formar uma estrutura que demonstre a reação trazida pelas IFRS ao ambiente contábil.

Foi utilizado o $\operatorname{SPSS}^{4}$ para a elaboração da análise fatorial, utilizando do método Principal Axis Factoring (Fatoração em Eixos Principais), o qual fornecem melhores resultados quando as amostras apresentam distribuição normal e não-normal, respectivamente (COSTELLO; ORBONE, 2005).

Após encontrado o índice remetido pela análise fatorial, procurou-se resumir os dados através da estatística descritiva, no sentido de analisar o comportamento desse índice nos diferentes países e a reação deles quando estão ou não na presença das IFRS. As medidas descritivas utilizadas foram: Medidas de tendência central (restringindo-se a média e a mediana); medidas de dispersão (restringindo-se aos valores mínimo, máximo, e o desviopadrão).

No sentido de identificar se existe diferença estatística significativa entre os países quando analisados sob a ótica do período pré-IFRS e pós-IFRS foi realizado o teste-t, que é um teste de significância aplicado quando se pretende comparar as médias de uma variável quantitativa em dois grupos diferentes. Esse teste é usado quando a distribuição é normal. Foram usados testes de Kolmogorov-Smirnov e Shapiro-Wilks para testes normais de distribuição. Como resultado da análise, determinou-se que as variáveis foram distribuídas normalmente para $\mathrm{p}>0,05$.

\footnotetext{
${ }^{4}$ Copyright $\odot$ SPSS Inc. All rights reserved
} 


\subsubsection{Regressão Logística}

A regressão logística busca explicar ou predizer valores de uma variável em função de valores conhecidos de outras variáveis (DIAS FILHO; CORRAR, 2009).

A regressão logística foi utilizada por ser uma técnica apropriada a situações em que se deseja predizer ou explicar valores de uma variável binária em função de valores conhecidos de outras variáveis. Trata-se, então, de uma situação em que a variável dependente só pode assumir um entre dois resultados, sendo de natureza binária.

A regressão logística tem sido preferida, em função de suas propriedades e da relativa simplicidade operacional. O uso de distribuições com caudas mais pesadas tem sido preconizado em alguns modelos quando as variáveis se distanciam da normalidade, como é o caso de muitas variáveis econômicas e no caso da regressão logística, "o pesquisador consegue contornar certas restrições encontradas em outros modelos multivariados, entre as quais se destacam a homogeneidade de variância e a normalidade da distribuição dos erros" (DIAS FILHO; CORRAR, 2009, p. 291).

Em se tratando de variáveis com duas categorias que podem ser classificadas como "sucesso" ou "fracasso", com possibilidade da variável resposta assumindo valores de, por exemplo, 1 e 0 , respectivamente, estas podem ser caracterizadas pela distribuição de Bernoulli. Para esses casos, o modelo assume a representação da Equação 17.

$$
\mathrm{y}_{i}=x_{i}^{T} \boldsymbol{\beta}+\varepsilon_{i}
$$

Em que, $x_{i}^{T}=\left[1, x_{i 1}, x_{i 2}, \ldots, x_{i k}\right], \boldsymbol{\beta}^{T}=\left[\beta_{0}, \beta_{1}, \beta_{2}, \ldots, \beta_{k}\right]$ e a variável resposta $\left(y_{i}\right)$ apresenta os valores 1 ou 0 . Nesse caso, reconhece-se que a variável resposta ( $\mathrm{y}_{\mathrm{i}}$ ) é uma variável aleatória de Bernoulli, com $\pi_{\mathrm{i}}$ sendo a probabilidade do valor $\mathrm{y}_{\mathrm{i}}=1$, conforme exposto na Tabela 3 (AGRESTI, 2007).

$\underline{\text { Tabela } 3 \text { - Valores assumidos pelas probabilidades }}$

\begin{tabular}{ll}
\hline $\mathrm{y}_{\mathrm{i}}$ & Probabilidade \\
\hline 1 & $\mathrm{P}\left(\mathrm{y}_{\mathrm{i}}=1\right)=\pi_{\mathrm{i}}$ \\
0 & $\mathrm{P}\left(\mathrm{y}_{\mathrm{i}}=0\right)=1-\pi_{\mathrm{i}}$ \\
\hline
\end{tabular}

Fonte: Adaptado (AGRESTI, 2007). 
Dado que, $E\left(\varepsilon_{i}\right)=0$, o valor esperado da variável resposta é o observado na Equação 18.

$$
E\left(y_{i}\right)=1-\left(\pi_{i}\right)+0\left(1-\pi_{i}\right)=\pi_{i}
$$

Isto implica a Equação 19,

$$
E\left(y_{i}\right)=x_{i}^{T} \beta=\pi_{i}
$$

Assim, tem-se que a resposta esperada dada pela função resposta: $E\left(y_{i}\right)=x_{i}^{T} \beta$, que é a probabilidade da variável resposta assumir o valor 1. Assim, se a resposta é binária, no modelo de regressão, o erro $\varepsilon_{i}$ poderá assumir apenas dois valores, tais quais as Equações 20 e 21.

$$
\begin{gathered}
\varepsilon_{i}=1-x_{i}^{T} \beta \text { quando } y_{i}=1 \\
\varepsilon_{i}=-x_{i}^{T} \beta \text { quando } y_{i}=0
\end{gathered}
$$

Desta maneira, os erros neste modelo não terão a possibilidade de serem normais, e a variância não será constante (AGRESTI, 2007).

Geralmente, quando a variável resposta é binária, há comprovações empíricas de que a forma da função resposta é não linear. Neste caso, emprega-se uma transformação na expressão, que passa a se chamar função resposta logística, pela expressão exposta na Equação 22 (AGRESTI, 2007).

$$
E(\mathrm{y})=\frac{1}{1+\exp \left(-x^{T} \beta\right)}
$$

Muitas das funções de distribuição têm sido propostas, porém, a função ideal para o caso da variável resposta ser dicotômica é a função logit, pois é extremamente flexível e fácil de ser usada e interpretada (AGRESTI, 2007). Conforme a equação 23. 


$$
\log i t\left(\pi_{i}\right)=\ln \left(\frac{\pi_{i}}{1-\pi_{i}}\right)=\beta_{0}+\beta_{1} x_{1}+\cdots+\beta_{k} x_{k}+\varepsilon_{i}=\eta i+\varepsilon_{i}
$$

Em que, Logit $\left(\pi_{\mathrm{i}}\right)=$ logaritmo da razão de chances entre $\mathrm{p}(\mathrm{y}=1)$ e $\mathrm{p}(\mathrm{y}=0) ; \pi_{\mathrm{i}}=\mathrm{p}(\mathrm{y}=1)$; $\beta_{0}$ e $\beta_{\mathrm{j}}$ = parâmetros a serem estimados; $\mathrm{x}_{\mathrm{i}}=$ variáveis independentes; e $\varepsilon_{i}=$ Erro aleatório.

A partir do momento que se define o modelo, faz-se necessário testar a sua validade. Em uma regressão logística, a validade do modelo pode ser testada por meio de gráficos, testes de ajustes ou outras medidas, permitindo identificar se existem variáveis que não se ajustam de uma maneira ideal ao modelo ou verificando variáveis que apresentam forte influência sobre a estimação dos parâmetros.

Assim, tem-se a curva da Regressão Logística que, segundo Dias Filho e Corrar (2009, p. 290), "descreve a relação existente entre a probabilidade associada à ocorrência de determinado evento e um conjunto de variáveis preditoras".

Para a avaliação geral da regressão logística, tem-se o Log Likelihood Value, o qual é um indicador que tem como objetivo medir a capacidade de o modelo estimar a probabilidade de ocorrência de um determinado evento (DIAS FILHO; CORRAR, 2009).

Um dos testes utilizados para validar o modelo de regressão logística binária é o teste de Hosmer-Lemeshow, o qual pode ser utilizado para avaliar quão bem o modelo escolhido se ajusta aos dados e avalia o modelo ajustado comparando as frequências observadas e as esperadas, ou seja, verifica "se existem diferenças significativas entre as classificações realizadas pelo modelo e a realidade observada" (DIAS FILHO; CORRAR, 2009, p. 296).

Tem-se ainda o teste de estatística Wald, o qual tem, como finalidade, "aferir o grau de significância de cada coeficiente da equação logística, inclusive a constante" (DIAS FILHO; CORRAR, 2009, p. 296). A ideia é verificar se determinado coeficiente é significativamente diferente de zero. 


\section{RESULTADOS}

\subsection{Estatística Descritiva}

Considerando que o Beta é um indicador que verifica a sensibilidade histórica entre os ativos, sendo aqui trabalhado pela relação entre o índice de mercado do país e o índice mundial, representando uma medida de risco do mercado como um todo. Desse modo, quanto maior a dispersão dos resultados dos Betas, maior a indicação de risco. Foram traçados 3 cenários: o primeiro estuda toda amostra utilizada; o segundo analisa o Beta sem a presença da IFRS, de forma que, o número de observações varia para cada País, pois se inclui na linha do tempo de Betas coletados, o período de tempo que cada País ainda não tinha adotado a IFRS, o que variou de País para País; e por fim, o terceiro analisa o Beta com a presença da IFRS, assim, como no cenário vai haver variação no número de observações para cada País, pois se inclui o período de tempo que cada País já tinha adotado a IFRS. Deve-se destacar que para toda análise feita nessa pesquisa que houve a separação entre Pré e Pós IFRS o raciocínio utilizado foi o mesmo aqui ressaltado.

Tabela 4 - Estatística descritiva dos Betas Estimados

\begin{tabular}{lrrr}
\hline & BETA (Amostra Total) & BETA (PRÉ-IFRS) & BETA (PÓS-IFRS) \\
\hline Média & 0,970914 & 0,990211 & 0,954029 \\
Mediana & 0,918607 & 0,930472 & 0,913576 \\
Mínimo & 0,177954 & 0,177954 & 0,333909 \\
Máximo & 2,183903 & 2,183903 & 2,031527 \\
Amplitude & 2,005948 & 2,005948 & 1,697618 \\
Desvio Padrão & 0,354583 & 0,398888 & 0,314389 \\
Coeficiente de Variação & 0,365206 & 0,402831 & 0,329538 \\
\hline
\end{tabular}

Fonte: Dados da pesquisa, 2016.

O Beta médio da amostra foi muito próximo de 1,0 (Conforme Tabela 4), o que permite inferir que o risco dos países em sua totalidade, na amostra investigada, foi muito próximo ao risco de mercado mundial.

Para o Beta (Pré-IFRS) e o Beta (Pós-IFRS) (Ver Tabela 4), o resultado no geral tem a mesma interpretação da amostra total, no entanto, é válido salientar que houve uma leve baixa na média do Beta (Pós-IFRS), podendo ser um indicativo que a presença da norma trouxe uma suave diminuição do risco, confirmando o que se discute sobre as IFRS, no sentido de que essas mudanças aumentam a qualidade da informação e, portanto, diminui as expectativas de risco sistêmico.

As medianas foram muito próximas para os Betas obtidos nas três situações (Ver Tabela 4), de forma que o valor que separa o rol em duas partes iguais se manteve nas diferentes 
posições, mostrando que, mesmo com ou sem as IFRS, a mediana se apresenta similar, próxima de 1,0 e, embora inferior à média, ainda valida a observação da tendência para a igualdade do comportamento dos Betas dos países em relação ao comportamento do mercado mundial.

O valor mais baixo ao qual o Beta estimado chegou foi idêntico na amostra total e na amostra pré-IFRS, ficando bem abaixo da média e consideravelmente menor que 1,0 (Ver Tabela 4), podendo-se inferir que é próximo de zero $(0,17)$, representando uma situação em que praticamente não existe risco. No entanto, visualiza-se que tal situação se desvirtua da média, justamente por isso que a amplitude desses dados se mostra superior a 1,0 (Ver Tabela 4), indicando inclusive que o estudo do comportamento do Beta nos países se mostra com maior indicativo de risco que o comportamento do Beta em termos do mercado de capitais mundial.

No Beta (Pós-IFRS) o valor mínimo já se distanciou do zero, comparado às situações anteriores (Ver Tabela 4), contrariando o que apregoa a teoria, dado que, na presença das IFRS, o Beta tenderia a zero, considerando que o aumento da qualidade da informação contábil seria responsável pela diminuição do risco da firma. Cabe ressaltar, contudo, que essa medida detém uma análise restrita, tanto que, ao se analisar a amplitude, já se encontra um valor bem mais baixo que a amplitude das situações anteriores e mais próximo de 1,0 (Ver Tabela 4), ficando assim mais próximo da média e da mediana.

A medida estatística do desvio-padrão tem comumente representado uma medida primária de risco, indicando a dispersão das variáveis (retornos esperados) em relação à média. Desvios mais altos são geralmente associados ao maior risco, mas no sentido de visualizar que os dados estão mais afastados da média. Assim, quando se observa que o desvio-padrão do Beta Pré-IFRS foi levemente maior que o Beta Pós-IFRS (Ver Tabela 4), pode-se remeter ao fato de que a presença das IFRS conseguiu diminuir sutilmente o afastamento dos Betas em relação à média, o que pode ser um indicativo de um tênue aumento da qualidade da informação contábil. Quando se observou toda a amostra, ainda se verificou uma pequena baixa em relação ao PréIFRS, já indicando que a presença das IFRS mudou o comportamento dos dados e, nesse sentido, diminui o afastamento em relação à média.

O coeficiente de variação trabalha com o grau de concentração dos dados em torno da média, sendo representado pela razão entre o desvio padrão e a média. A indicação é no sentido de demonstrar a dispersão relativa, demonstrando percentualmente a dispersão dos dados em relação à média. A distribuição em análise se mostra perdendo a homogeneidade, pois os coeficientes de variação das três situações ultrapassam 20\% (Ver Tabela 4). No entanto, é válido salientar que os Betas pós-IFRS apresentaram um menor coeficiente de variação, mais próximo 
dos $20 \%$, de forma que, após as IFRS, houve uma maior homogeneidade, embora tênue, entre os dados em estudo.

Para melhor descrever e resumir os dados através das realidades individuais de cada país, calculou-se a média e a mediana dos Betas estimados para cada um deles, trabalhando uma situação com amostra total e outra segregando a ausência e presença das IFRS (Ver Tabela $5)$.

Tabela 5 - Média e Mediana segregada por país (Amostra Total)

\begin{tabular}{|c|c|c|c|c|}
\hline \multirow[b]{2}{*}{ País } & \multicolumn{4}{|c|}{ IFRSAMOSTRA } \\
\hline & Média & Mediana & $\begin{array}{l}\text { Desvio- } \\
\text { Padrão }\end{array}$ & $\begin{array}{c}\text { Coeficiente de } \\
\text { Variação } \\
\end{array}$ \\
\hline Austrália & 0,658398 & 0,629078 & 0,151999 & 0,230861 \\
\hline Canadá & 0,754038 & 0,727769 & 0,135666 & 0,179919 \\
\hline França & 0,965037 & 0,991458 & 0,129595 & 0,134290 \\
\hline Alemanha & 1,123471 & 1,105379 & 0,205732 & 0,183122 \\
\hline Itália & 0,980891 & 0,960449 & 0,165590 & 0,168816 \\
\hline Brasil & 1,282937 & 1,316309 & 0,254862 & 0,198655 \\
\hline Rússia & 1,471262 & 1,432318 & 0,295452 & 0,200815 \\
\hline China & 1,064618 & 1,103755 & 0,172480 & 0,162011 \\
\hline África do Sul & 1,152084 & 1,130342 & 0,450154 & 0,390730 \\
\hline Nova Zelândia & 0,429592 & 0,432094 & 0,138152 & 0,321589 \\
\hline Reino Unido & 0,797728 & 0,809175 & 0,081914 & 0,102685 \\
\hline
\end{tabular}

Fonte: Dados da pesquisa, 2016.

Ao se analisar os dados totais da amostra, é possível observar que a média e a mediana de países como Alemanha, Brasil, Rússia, China e África do Sul estão acima de 1,0 (Ver Tabela 5), indicando que, no decorrer do período analisado, existe uma tendência de os dados se centralizarem em torno do Beta igual ou maior que 1,0, indicando que o risco do país está superando o risco de mercado mundial. Pode-se dizer que o resultado encontrado corrobora com o estudo de Godeiro (2015), no qual os países emergentes (tal como os países evidenciados na Tabela 5, com exceção da Alemanha) partiram de um estágio de estagnação ou subdesenvolvimento e estão emergindo para o desenvolvimento econômico.

Os países emergentes exibem panoramas de crescimento econômico promissor e características socioeconômicas que os distinguem das demais economias periféricas. Os mercados de capitais nesses países também são considerados como em desenvolvimento, no sentido de que as negociações não são intensas e a expectativa futura ainda é indefinida.

Godeiro (2015) destacou que os países emergentes são supostamente mais arriscados, uma vez que apresentam uma economia em ascensão e, nesse sentido, não se desvincula das dúvidas a respeito do futuro econômico, trabalhando com índices que oscilam entre baixo e 
médio, contendo grande incerteza sobre as operações econômicas. Portanto, esperava-se que a média e a mediana dos Betas fossem acima de 1,0 para países com essas características, indicando que o nível de risco aos quais estariam submetidos é maior que o do mercado mundial, já que são países com um mercado de capitais em desenvolvimento, credibilidade do mercado em construção e expectativas futuras com grande incerteza.

A Alemanha, por ser um país desenvolvido, caracterizado por uma economia forte, desenvolvimento científico e tecnológico elevado, população ativa empregada e mercado de capitais bem estruturado, esperava-se um Beta médio abaixo de um, indicando que o nível de risco ao qual tal país está submetido é menor que o do mercado mundial, já que é um país com um mercado de capitais forte e com boa credibilidade além de boas expectativas futuras. Porém, na pesquisa de Godeiro (2015), a Alemanha já estava entre o grupo de países que teve Betas maiores que " 1 ".

Nessa linha, todos os países desenvolvidos, com exceção da Alemanha como reforçado anteriormente, mostraram-se com médias e medianas abaixo de 1,0 (Ver Tabela 5), conforme esperado, considerando que são países com as características de um mercado de capitais confiável e com uma circulação de negócios intensa. A Nova Zelândia apresentou o menor Beta médio indicando que existe maior segurança em seu mercado, podendo-se ressaltar que a cultura também interfere nessa relação, considerando que a confiança nas relações é intensa, assim a incerteza é menor.

Para o desvio-padrão dos Betas considerando a amostra total, o maior foi o do Beta da África do Sul (Ver Tabela 5), demonstrando uma alta dispersão entre os Betas estimados. Como a média desse país também esteve entre as mais altas, pode-se retomar o estudo de Godeiro (2015) e estabelecer que existe confirmação de sua pesquisa, que apontou maiores variâncias para esse país. O país com o menor desvio-padrão foi o Reino Unido, demonstrando que houve uma baixa dispersão entre os dados (Ver Tabela 5).

Todos os países desenvolvidos apresentaram desvio-padrão abaixo de 0,2 (Ver Tabela 5), corroborando a ideia que a expectativa com relação ao risco é mais moderada nesses países. Para os países emergentes, somente a China ficou com desvio-padrão menor que 0,2. Godeiro (2015) também observou que a China seguia um caminho de risco moderado, embora, neste trabalho, a China apresentou um Beta médio maior que $1(1,06)$ (Ver Tabela 5).

O coeficiente de variação é considerado mais adequado para comparar grupos distintos, assim, verifica-se, conforme Tabela 5, que a maioria dos países tem uma dispersão maior que aqui havia sido apresentada quando calcula somente o desvio-padrão, com exceção da Alemanha, Brasil, Rússia, China e África do Sul. Assim, tem-se um resultado onde todos os 
países emergentes apresentaram menor homogeneidade entre o Beta, já nos países desenvolvidos não se teve a totalidade com a mesma característica, embora a maioria apresentou maior estabilidade na comparação dos Betas.

O Gráfico 1, demonstra o comportamento médio do Beta para amostra total segregado por país, na sequência dos países trabalhados na Tabela 5, permitindo que se visualize que os Betas circundam a linha do valor 1,0, situando-se um pouco abaixo ou um pouco acima.

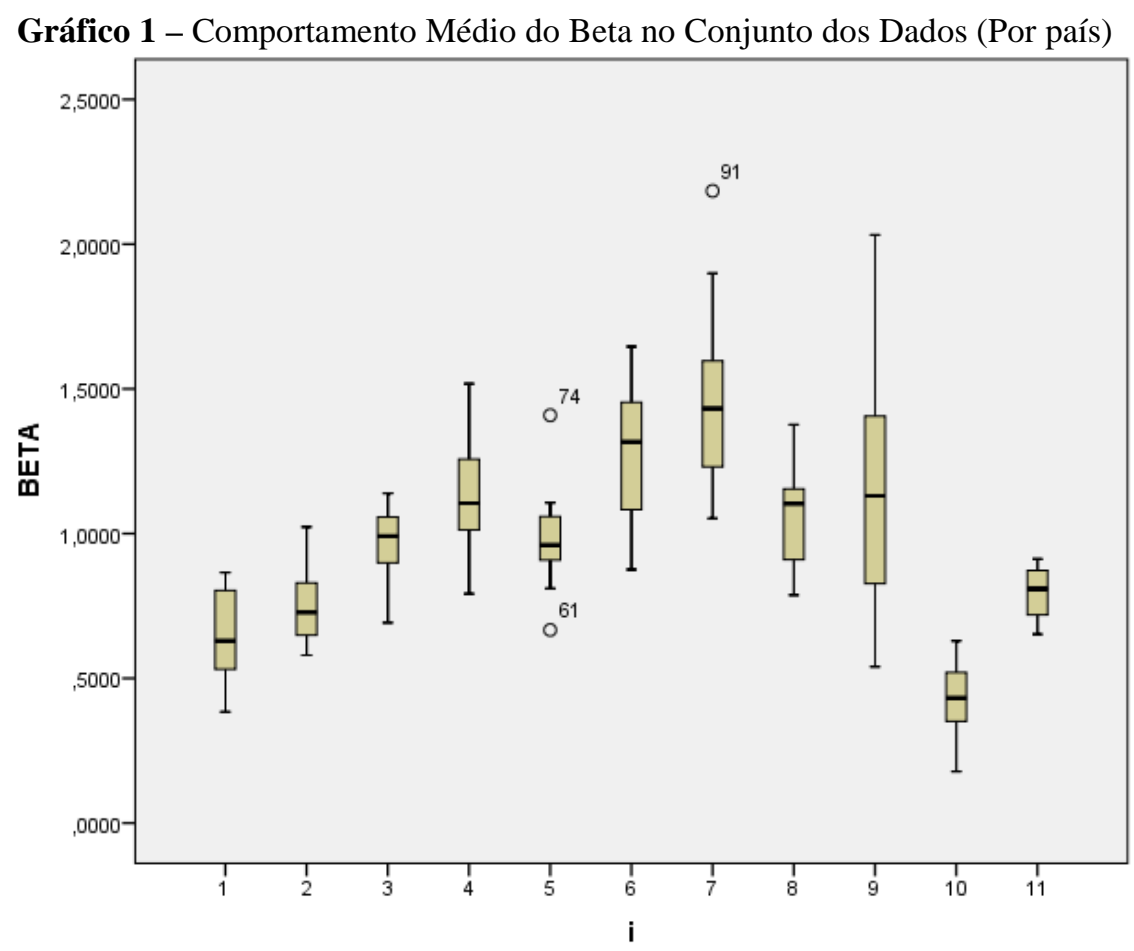

Fonte: Dados da pesquisa, 2016.

Ao se dividir a amostra para os dados pré-IFRS e pós-IFRS, os Betas médios e as medianas do Beta para a maioria dos países aumentou ao invés de diminuir (Ver Tabela 6). No entanto, esperava-se uma redução dos Betas dada a expectativa do aumento da qualidade da informação em virtude da adoção das IFRS, no sentido de que haveria diminuição das incertezas sobre as expectativas sobre as firmas e, consequentemente, redução do risco. 
Tabela 6 - Média e Mediana dos Betas segregadas por país (subdivisões)

\begin{tabular}{ccccccccc}
\hline \multirow{2}{*}{ País } & \multicolumn{3}{c}{ PRÉ-IFRS } & \multicolumn{3}{c}{ PÓS-IFRS } \\
\cline { 2 - 9 } & Média & Mediana & $\begin{array}{c}\text { Desvio- } \\
\text { Padrão }\end{array}$ & $\begin{array}{c}\text { Coeficiente } \\
\text { de Variação }\end{array}$ & Média & Mediana & $\begin{array}{c}\text { Desvio- } \\
\text { Padrão }\end{array}$ & $\begin{array}{c}\text { Coeficiente } \\
\text { de Variação }\end{array}$ \\
\hline Austrália & 0,523749 & 0,523690 & 0,112434 & 0,214671 & 0,725722 & 0,789454 & 0,123337 & 0,169951 \\
Canadá & 0,794614 & 0,786036 & 0,133016 & 0,167397 & 0,642452 & 0,631068 & 0,065383 & 0,101771 \\
França & 0,960314 & 0,954918 & 0,179105 & 0,186507 & 0,967398 & 1,010205 & 0,108856 & 0,112524 \\
Alemanha & 1,181892 & 1,260947 & 0,286240 & 0,242188 & 1,094261 & 1,103427 & 0,163037 & 0,148993 \\
Itália & 0,882323 & 0,865189 & 0,157311 & 0,178291 & 1,030174 & 0,985608 & 0,153489 & 0,148993 \\
Brasil & 1,370674 & 1,351550 & 0,243486 & 0,177640 & 1,107463 & 1,034976 & 0,190304 & 0,171838 \\
Rússia & 1,473781 & 1,449555 & 0,329459 & 0,223547 & 1,461188 & 1,432318 & 0,117750 & 0,080585 \\
China & 1,068358 & 1,107874 & 0,113427 & 0,106170 & 1,061347 & 1,079038 & 0,220102 & 0,207380 \\
África do Sul & 0,825583 & 0,708682 & 0,346073 & 0,419186 & 1,315334 & 1,230824 & 0,416114 & 0,316356 \\
Nova Zelândia & 0,403854 & 0,374452 & 0,182837 & 0,452730 & 0,452112 & 0,454925 & 0,090973 & 0,201218 \\
Reino Unido & 0,787723 & 0,780717 & 0,081903 & 0,103974 & 0,802731 & 0,830509 & 0,085866 & 0,106967 \\
\hline
\end{tabular}

Fonte: Dados da pesquisa, 2016.

É válido ressaltar que, no pós-IFRS, a maioria dos países emergentes (Brasil, Rússia e China - com exceção da África do Sul) teve uma pequena redução na média e mediana do Beta (Ver Tabela 6), assim, mesmo pequena, indica uma mudança no quadro.

Sendo os países emergentes acostumados com a vivência diária de mudanças em termos econômicos, sempre buscando aumentar o desenvolvimento, é possível que o Pós-IFRS tenha sido enfrentado dentro de um rol de boas expectativas. O caso da África do Sul merece destaque devido ao fato de que esse país já apresenta um quadro de risco acentuado (GODEIRO, 2015), de forma que a presença das IFRS pode ter aumentado a incerteza ao invés de diminuir.

Os países desenvolvidos, com exceção do Canadá e Alemanha, apresentaram aumento do Beta, ao invés de queda (Ver Tabela 6), conforme esperado. É possível que, dada a estabilidade desses mercados, as IFRS vieram acompanhadas de restrições em termos das preocupações formadas em torno das expectativas futuras, de forma que o mercado desses países, historicamente, apresenta-se forte, sendo possível que as mudanças não sejam tão bem aceitas. Além do que, os padrões de Contabilidade anteriormente estabelecidos, possivelmente eram mais aceitos pela sociedade que as IFRS, o que pode ter levado ao resultado encontrado.

A análise do desvio-padrão esclarece os apontamentos realizados a respeito da média e mediana dos Betas, a notar que somente a Austrália, China e África do Sul não apresentaram baixa no desvio-padrão para o Pós-IFRS. A China e a África do Sul tiveram um aumento acima de 0,1 . Pressupõe-se que, em termos de dispersão (variação no risco), o Pós-IFRS teve uma boa resposta para a maioria dos países. 
A medida do coeficiente de variação foi menor no Pós-IFRS para praticamente todos os países, com exceção da China, o que se torna um indicativo que com a inserção da IFRS houve maior homogeneidade entre os Betas dos Países em geral (Ver Tabela 6). Quanto ao comportamento do Beta ao se usar o coeficiente de variação ao invés do desvio-padrão o comportamento dos três cenários se mostrou similar, de forma que, os países emergentes mostraram em sua totalidade maior dispersão entre os Betas e os países desenvolvidos, em sua maioria, revelaram menor variabilidade (Ver Tabelas 5 e 6).

O Gráfico 2, demonstra o comportamento médio do Beta segregado por país e, em destaque, o pré-IFRS (Dummy=0) e o pós-IFRS (Dummy=1), usando a sequência dos países trabalhados na Tabela 6, permitindo que se visualize que não existe um padrão nos Betas dos países após a adoção da IFRS, conforme aqui discutido, uma vez que, para alguns países, o Beta aumentou, para outros diminuiu e ainda tem aqueles que a variação foi praticamente inexistente.

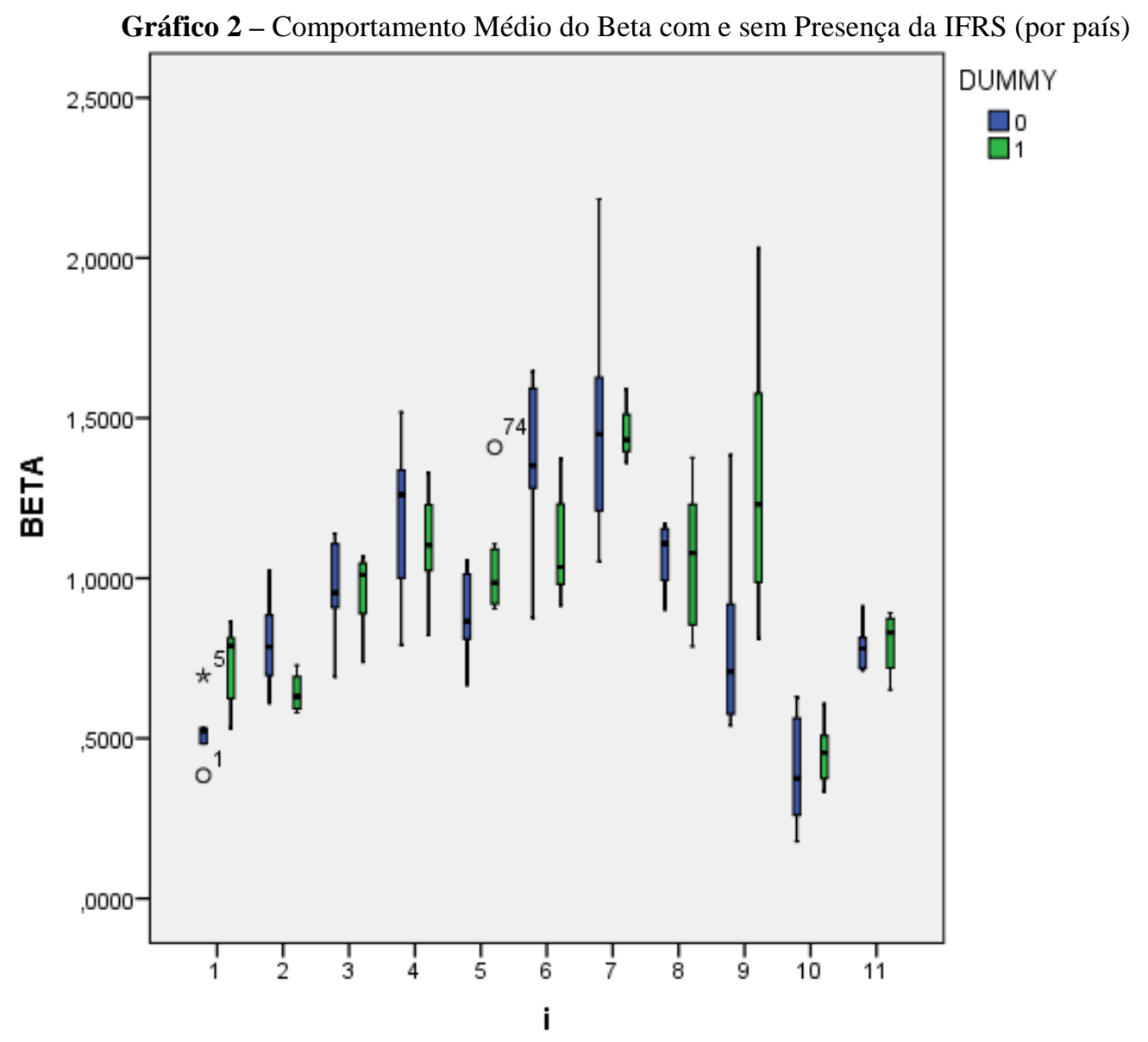

Fonte: Dados da pesquisa, 2016.

O Teste $\mathrm{t}$ (aplicado por se tratar de dados normais - Ver Tabela 7), ratifica o exposto na Tabela 6 e Gráfico 2, de forma que os países, quando em análises individuais, não apresentaram 
diferença estatística significativa (considerando o valor-p menor que 5\%) entre pré e pós-IFRS (Ver Tabela 7), com exceção de Austrália e África do Sul. O que também é confirmado, quando se examina o conjunto dos dados referindo-se a “Todos” os países (Ver Tabela 7).

Tabela 7 - Teste Ed t-Student para Estudo do comportamento do Beta por país e com a presença da IFRS

\begin{tabular}{|c|c|c|c|}
\hline País & Dummy & $\begin{array}{l}t \text {-Student } \\
\text { Valor-p }\end{array}$ & $\begin{array}{l}\text { Teste de normalidade de } \\
\text { Shapiro-Wilks (Valor-p) }\end{array}$ \\
\hline Austrália & $\begin{array}{l}0 \\
1\end{array}$ & 0,009 & 0,256 \\
\hline Canadá & $\begin{array}{l}0 \\
1\end{array}$ & 0,050 & 0,374 \\
\hline França & $\begin{array}{l}0 \\
1\end{array}$ & 0,925 & 0,293 \\
\hline Alemanha & $\begin{array}{l}0 \\
1\end{array}$ & 0,457 & 0,896 \\
\hline Itália & $\begin{array}{l}0 \\
1\end{array}$ & 0,105 & 0,260 \\
\hline Brasil & $\begin{array}{l}0 \\
1\end{array}$ & 0,055 & 0,437 \\
\hline Rússia & $\begin{array}{l}0 \\
1\end{array}$ & 0,950 & 0,313 \\
\hline China & $\begin{array}{l}0 \\
1\end{array}$ & 0,941 & 0,509 \\
\hline África do Sul & $\begin{array}{l}0 \\
1\end{array}$ & 0,042 & 0,629 \\
\hline Nova Zelândia & $\begin{array}{l}0 \\
1\end{array}$ & 0,543 & 0,722 \\
\hline Reino Unido & $\begin{array}{l}0 \\
1\end{array}$ & 0,751 & 0,322 \\
\hline Todos & $\begin{array}{l}0 \\
1\end{array}$ & 0,523 & \\
\hline
\end{tabular}

Fonte: Dados da pesquisa, 2016.

Somente, com a Estatística Descritiva não se consegue alcançar inferências amplas das possíveis causas dos resultados aqui encontrados, de modo que foram realizados outros tipos de análises no intuito de melhor explorar esses resultados.

\subsection{Teste da correlação entre os países}

Na matriz de correlação entre os países, foi possível identificar a correlação entre os Betas estimados dos diversos países, permitindo se fazer inferências se existem relações entre as alterações sofridas nos Betas estimados de um país com as modificações nos Betas estimados de países com os quais se mostrousse correlacionados (Ver Tabela 8). 
Tabela 8 - Matriz de Correlação dos Betas Estimados entre os países

\begin{tabular}{|c|c|c|c|c|c|c|c|c|c|c|c|}
\hline & AUS & BRA & CHIN & CAN & $\mathrm{AL}$ & UK & IT & FRA & NZ & RUS & SAF \\
\hline AUS & 1,00 & & & & & & & & & & \\
\hline BRA & 0,52 & 1,00 & & & & & & & & & \\
\hline CHIN & 0,51 & 0,52 & 1,00 & & & & & & & & \\
\hline CAN & 0,12 & 0,63 & 0,46 & 1,00 & & & & & & & \\
\hline $\mathrm{AL}$ & 0,44 & 0,54 & 0,24 & $-0,01$ & 1,00 & & & & & & \\
\hline UK & 0,58 & 0,45 & 0,30 & 0,07 & 0,66 & 1,00 & & & & & \\
\hline IT & 0,39 & $-0,11$ & $-0,09$ & $-0,46$ & 0,38 & 0,47 & 1,00 & & & & \\
\hline FRA & 0,55 & 0,44 & 0,22 & $-0,05$ & 0,89 & 0,76 & 0,53 & 1,00 & & & \\
\hline $\mathrm{NZ}$ & 0,86 & 0,49 & 0,31 & 0,10 & 0,40 & 0,49 & 0,24 & 0,44 & 1,00 & & \\
\hline RUS & 0,29 & 0,63 & 0,51 & 0,67 & 0,08 & 0,11 & $-0,22$ & 0,03 & 0,16 & 1,00 & \\
\hline SAF & 0,49 & 0,28 & 0,31 & 0,09 & 0,15 & 0,26 & 0,08 & 0,24 & 0,56 & 0,19 & 1,00 \\
\hline
\end{tabular}

Fonte: Dados da pesquisa, 2016.

Não se encontrou um padrão, entre os resultados, ao se confrontar os dados destinados aos países emergentes mais correlacionados com países emergentes, ou mesmo de países desenvolvidos mais correlacionados com países desenvolvidos.

A Austrália apresentou uma correlação positiva regular com a maioria dos países investigados. Assim, existe uma tendência razoável de que, quando o risco da Austrália aumenta, o risco de países desenvolvidos como França e Reino Unido também aumenta, da mesma forma que o raciocínio também é válido para países emergentes como Brasil e China. Deve-se destacar a correlação forte apresentada da Austrália com a Nova Zelândia, o que pode ser atribuído ao fato de os dois países fazerem parte do mesmo grupo econômico, o que aumenta as similaridades econômicas entre eles. O Canadá apresentou uma correlação positiva fraca com a Austrália, de modo que a variação no risco de um desses países, possivelmente, não tende a responder da mesma forma no outro (Ver Tabela 8).

A correlação do Brasil com a maioria dos países analisados foi uma correlação positiva regular, de forma que a correlação existe tendendo para o mesmo sentido, mas em forma não tão intensa. Deve-se destacar a correlação praticamente nula do Brasil com a Itália. E é importante enfatizar a correlação positiva forte do Brasil com o Canadá e a Rússia, ressaltando a falta de padrão entre a correlação dos países, pois o Brasil se correlacionar com a Rússia seria até esperado, já que fazem parte do mesmo grupo econômico e ambos são países emergentes, no entanto, a correlação com oCanadá, que é um país desenvolvido e faz parte de um grupo econômico bem mais expressivo, já não seria esperada (Ver Tabela 8).

A China também apresentou correlação positiva regular com a maioria dos países, com exceção da Alemanha e França com quem apresentou correlação positiva fraca. A correlação 
da China com a Itália, assim como ocorreu com o Brasil, foi praticamente nula, onde os motivos podem ser os mesmos, sendo a China e o Brasil países emergentes e participantes do mesmo grupo econômico (Ver Tabela 8).

O Canadá apresentou uma correlação fraca com uma boa parte dos países em análise, sejam eles desenvolvidos (a exemplo da França) ou emergentes (a exemplo da África do Sul). Destaca-se a relação forte apresentada com o Brasil (já ressaltada aqui) e com a Rússia, sendo esses países emergentes. A relação do Canadá com a Itália, embora desenvolvidos e participantes do mesmo grupo econômico, foi regular e negativa, no caso a correlação existe, mesmo que moderada, mas quando o risco de um país caminha para um lado, o do outro país toma rumos contrários (Ver Tabela 8).

Pode-se dizer que a Alemanha tem uma correlação positiva muito forte com a França, na medida em que amplia, consideravelmente, a possibilidade de o risco desses países apresentar o mesmo comportamento. A correlação da Alemanha com o Reino Unido foi positiva forte, também tendo uma expectativa grande para o risco de um variar segundo a variação do outro. Com a Rússia e a África do Sul, a Alemanha teve correlações positivas fracas, muito próximas de correlações nulas, o que pode ter sido uma interferência se considerar o fato de esses dois países serem emergentes. Para os demais países, os que aqui não foram explanados, houve correlação positiva regular (Ver Tabela 8).

O Reino Unido teve uma correlação positiva forte com a França. Com a Rússia e a África do Sul, países emergentes, o Reino Unido manteve uma correlação positiva fraca, de fato que é improvável que a variação no seu risco interfira na variação do risco daqueles países (Ver Tabela 8).

Com todos os países fora do seu grupo econômico, a exceção da Austrália (regular), a Itália apresentou correlações fracas, sejam positivas ou negativas, nesse caso, as variações de risco da Itália praticamente não interferem nesses países e vice-versa. Com os países do seu grupo econômico as correlações foram regulares. Com nenhum país, a Itália demonstrou correlações fortes ou muito fortes (Ver Tabela 8).

Aqui já foram comentadas as correlações positivas fortes apresentadas pela França, assim como algumas correlações fracas e regulares. Apesar disso, é ainda interessante destacar que a correlação da França com a Rússia e a África do Sul foi positiva fraca, de forma que entre os países emergentes, somente o Brasil apresentou correlação regular com a França. Com os demais países fora do seu grupo econômico a correlação também foi positiva regular (Ver Tabela 8). 
A Nova Zelândia apresentou correlação positiva fraca com o Canadá, a Itália e a Rússia, também não apresentando padrão, já que se trata tanto de países desenvolvidos, como de um país emergente. Com exceção da Austrália, país do mesmo grupo econômico da Nova Zelândia, com os demais países a correlação foi positiva regular, podendo haver uma moderada interferência das variações no seu risco na variação desses países (Ver Tabela 8).

Com a grande maioria dos países, incluindo países emergentes (a exemplo da África do Sul), a Rússia teve correlações fracas, apresentando correlação positiva forte somente com o Canadá, de forma que, somente com esse, existe uma segurança maior para se dizer que as variações no risco de um país podem interferir no risco do outro (Ver Tabela 8).

A África do Sul também teve correlações positivas fracas com a maior parte dos países em análise, só com Austrália, China e Nova Zelândia que houve correlações positivas regulares. Dessa forma, as variações do risco da África do Sul têm pouca possibilidade de se alterar em resposta às variações do risco de outros países (Ver Tabela 8).

No geral, embora não se tenha encontrado um comportamento que possa ser citado como padrão em se tratando da correlação dos diversos países, a análise da matriz de correlação é capaz de permitir apontamentos sobre as expectativas dos caminhos a serem percorridos em termos de risco e das possíveis implicações das demais variáveis que ainda serão trabalhadas aqui.

Cappiello e Fearnley (2000) acrescentam que a diversificação internacional é apresentada como benéfica, de forma que não é possível afirmar que uma perturbação em um mercado de um país necessariamente afeta o mercado do outro país.

\subsection{Regressão Quantílica}

A regressão quantílica foi então usada para se estimar a mediana dos dados em estudo, uma vez que se tem a possibilidade de verificar relações preditoras mais úteis, considerando os casos que não exista qualquer relação ou relações fracas entre as médias das variáveis. Além disso, para dados econômicos, a regressão quantílica tem se apresentado indicada, dada a sua maior robustez à outliers e a não exigência dos pressupostos necessários para a operacionalização da Regressão por Mínimos Quadrados Ordinários, como distribuição normal dos dados e dos erros. E, por fim, as características da amostra, considerando as peculiaridades de cada um dos 11 países, provoca certa distinção nos dados em estudo, necessitando de um modelo capaz de desconsiderar as diferenças existentes. 
Os cenários de maior risco e menor risco não foram focos dessa análise, apenas o cenário de risco na mediana foi considerado importante para se alcançar o objetivo esperado.

Tabela 9 - Regressão Quantílica dos países em estudo - Beta (Variável Dependente) e Dummy (Variável Independente)

\begin{tabular}{cccccc}
\hline País & Variável & Coeficiente & Erro Padrão & t-Statistic & Probabilidade \\
\hline Austrália & DUMMYAUS & 0.230626 & 0.030220 & 7.631616 & 0.0000 \\
Alemanha & DUMMYALEM & -0.146760 & 0.053822 & -2.726755 & 0.0070 \\
Brasil & DUMMYBR & -0.254972 & 0.054003 & -4.721423 & 0.0000 \\
China & DUMMYCH & -0.054562 & 0.034925 & -1.562283 & 0.1199 \\
Canadá & DUMMYCAN & -0.135107 & 0.023662 & -5.709810 & 0.0000 \\
Reino Unido & DUMMYRU & 0.070307 & 0.022647 & 3.104484 & 0.0022 \\
Itália & DUMMYITAL & 0.101949 & 0.038250 & 2.665343 & 0.0084 \\
França & DUMMYFRAN & 0.001518 & 0.039168 & 0.038751 & 0.9691 \\
Nova Zelândia & DUMMYNZ & 0.066479 & 0.050386 & 1.319407 & 0.1887 \\
Rússia & DUMMYRUS & 0.040600 & 0.068888 & 0.589359 & 0.5563 \\
África do Sul & DUMMYAS & 0.473866 & 0.065899 & 7.190746 & 0.0000 \\
\hline
\end{tabular}

Fonte: Dados da pesquisa, $2016 .{ }^{5}$

Conforme a Tabela 9, visualiza-se que os sinais dos coeficientes da Alemanha, Brasil, China e Canadá se comportaram como o esperado, ou seja, a presença das IFRS impacta negativamente no risco, remetendo à possibilidade de a qualidade da informação contábil ter aumentado.

Para Austrália, Reino Unido, Itália, França, Nova Zelândia, Rússia e África do Sul, os sinais dos coeficientes foram contrários ao esperado (Ver Tabela 9), de forma que a presença das IFRS impactou positivamente no risco, nesse caso, não se poderia afirmar que houve aumento da qualidade da informação contábil, considerando que é possível que as incertezas sobre a informação contábil tivessem aumentado.

Nessa linha, a Austrália indicou aumento no risco e tal resultado foi estatiscamente significativo. Pode-se dizer que, considerando as características da Contabilidade da Austrália, apesar da perspectiva em qualquer país ser a diminuição do risco, o resultado encontrado era prenunciado, pois trata-se de um país cuja Contabilidade foi constituída na confiança de investidores, como um modelo contábil voltado para o usuário da informação, tendo sempre se exigido alto padrão quanto à mensuração e divulgação da informação contábil. Dessa forma, é possível inferir que a adoção das IFRS pode surgir como um fato novo que, de início, venha oferecer aumento da incerteza sobre as informações disponibilizadas pela Contabilidade desse país. Assim, considerando que, no período pré-adoção, as características da Contabilidade já eram praticamente as mesmas, a mudança vai no sentido de não se conhecer o impacto futuro da adoção das IFRS.

\footnotetext{
${ }^{5}$ As Tabelas Completas estão fornecidas no Apêndice A.
} 
A conformidade com as normas internacionais foi almejada pelos órgãos reguladores da Austrália, desde 1996 (CHALMERS; CLINCH; GODFREY, 2011). Sugere-se, então, que, considerando o fato de a Austrália ser um país categorizado por uma forte proteção aos investidores e por relatórios financeiros de alta qualidade, o fato de ele ter exigido a adoção das IFRS, possivelmente trouxe dúvidas quanto às grandes mudanças na forma de se praticar Contabilidade.

É válido salientar, que Chalmers, Clinch e Godfrey (2011) comentam que, apesar do histórico de Contabilidade forte na Austrália, o período pós-IFRS ainda remete, no geral, ao aumento da qualidade da informação contábil, apesar de não terem encontrado significância estatística para todas as variáveis investigadas, demonstrando que os resultados foram inconclusivos, tais como os resultados encontrados nesse estudo.

Considerando que o risco sistêmico decorre da possibilidade de perdas que podem ser ocasionadas por mudanças no comportamento nos preços das ações, nas taxas de juros e nas taxas de câmbio. Primeiramente, o Beta foi estudado segundo seu comportamento no Pré e PósIFRS, em seguida, inseriram-se variáveis de controle, Taxa de Câmbio e Taxa de Juros, para observar se a resposta encontrada mudaria.

Dessa forma, a Tabela 10 permite verificar que, na Austrália, mesmo que tenha se mostrado significante a Variável Taxa de Câmbio (considerando sempre que a significância se encontra abaixo de 5\%), a variável Dummy manteve o mesmo comportamento já relatado, quando da inserção das novas variáveis, ou seja, apresentou um coeficiente positivo, conduzindo ao aumento no risco, mantendo as inferências já realizadas para esse país.

Tabela 10 - Regressão Quantílica da Austrália - Beta (Variável Dependente) e Dummy, Taxa de Juros e Taxa de Câmbio (Variáveis Independentes)

\begin{tabular}{cccccc}
\hline País & Variável & Coeficiente & Erro Padrão & $t$-Statistic & Probabilidade \\
\hline 1 & DUMMYAUS & 0.338066 & 0.039424 & 8.575104 & 0.0000 \\
1 & TC & 1.941065 & 0.497336 & 3.902924 & 0.0001 \\
1 & TJ & -0.038669 & 0.020172 & -1.916905 & 0.0569 \\
\hline
\end{tabular}

Fonte: Dados da pesquisa, $2016 .^{6}$

Segundo Houqe, Easton e Van Zijl (2014), a Alemanha se caracteriza por ser um país com baixa proteção ao investidor e que teve, a partir da implantação das IFRS, uma melhoria na qualidade da informação contábil. O que foi corroborado pelo resultado aqui encontrado, considerando que o Pós-IFRS foi característico de uma redução estatisticamente significante no risco (Ver Tabela 9). Dada a característica da baixa proteção ao investidor, a diminuição no

\footnotetext{
${ }^{6}$ A Tabela Completa está no Apêndice A.
} 
risco representa um benefício para este usuário dado o aumento da confiabilidade nos investimentos realizados.

Para a Alemanha, portanto, a introdução das IFRS representou um ganho, posto que a informação contábil, nos moldes anteriores, apresentava forte influência fiscal. Nesse sentido, encontraram-se evidências significativas da redução do risco no período pós-IFRS (Ver Tabela 9). Para Bartov, Goldberg e Kim (2005), os padrões alemães foram desenvolvidos em um ambiente altamente politizado, servindo principalmente a partes interessadas, incluindo o foco em requisitos fiscais, em vez de se concentrar em ganhos de informatividade, de forma que o ganho proporcionado para a informação contábil da Alemanha ultrapassa a questão da legitimidade da institucionalização das firmas, mas proporciona o alinhamento dos relatórios fiscais e financeiros, aumentando o poder informativo da informação contábil.

Bartov, Goldberg e Kim (2005) comentam que, antes da adoção das IFRS, o modelo contábil da Alemanha não se preocupava com a divulgação de informações relevantes e após as IFRS observou-se um aumento do value-relevance para as variáveis investigadas. Embora esses autores tenham se restringindo a estudar value-relevance, em termos de qualidade da informação contábil, pode-se dizer que os resultados encontrados estão alinhados com os achados dessa pesquisa que analisa o aumento da qualidade da informação pós-IFRS via redução do Risco.

A Tabela 11 demonstra que a variável Dummy, na Alemanha, manteve o comportamento aqui já explorado quando da inserção das variáveis controles - e essas se mostraram insignificantes. A Dummy apresentou um coeficiente negativo, remetendo a uma diminuição no risco, de forma que, para esse país, os pontos aqui ressaltados não se alteram.

Tabela 11 - Regressão Quantílica da Alemanha - Beta (Variável Dependente) e Dummy, Taxa de Juros e Taxa de Câmbio (Variáveis Independentes)

\begin{tabular}{cccccc}
\hline País & Variável & Coeficiente & Erro Padrão & $t$-Statistic & Probabilidade \\
\hline 2 & DUMMYALEM & -0.136407 & 0.057304 & -2.380432 & 0.0184 \\
2 & TC & 0.535916 & 0.280388 & 1.911339 & 0.0576 \\
2 & TJ & -0.013595 & 0.035549 & -0.382427 & 0.7026 \\
\hline
\end{tabular}

Fonte: Dados da pesquisa, 2016. ${ }^{7}$

No Brasil, obteve-se um coeficiente negativo e estatisticamente significante (Ver Tabela 9), portanto, pode-se dizer que existem indícios de que o risco diminuiu no período pós-IFRS, de modo que, permite-se inferir que houve aumento na qualidade da informação contábil. Além da redução no risco encontrada nesse estudo, observa-se que - no enquadramento do Brasil ao

\footnotetext{
${ }^{7}$ A Tabela Completa está no Apêndice A.
} 
processo de convergência internacional - haveria vários pontos positivos, como melhores oportunidades para as multinacionais, aumento de relações negociais, além de haver redução de custos na elaboração de informações, não sendo mais necessária a reapresentação das informações visando ao atendimento de normas contábeis de outros mercados.

O Brasil não tinha, no Pré-IFRS, um padrão forte em termos de normas contábeis, de forma que a adoção das IFRS apresenta, como vantagem, o fato de se igualar a países que culturalmente trabalham com práticas contábeis que valorizam a essência econômica dos fatos, mudando assim a visão da Contabilidade perante a sociedade.

Os resultados encontrados nesse estudo corroboram diversas pesquisas realizadas no Brasil que apontam para o aumento da qualidade da informação contábil, como: Lima (2011); Macedo et al. (2011); Macedo et al. (2013); Silva (2013); Santos, Starosky Filho e Klann (2014); Martins et al. (2014). No entanto, as pesquisas no Brasil não têm sido conclusivas com relação ao fato de que a adoção das IFRS aumenta a qualidade da informação contábil, uma vez que pesquisas como as de Santos et al. (2011) e Macedo, Machado e Machado (2013) encontraram indícios de aumento da qualidade da informação contábil para umas variáveis e para outras não. Outras pesquisas ainda apresentaram evidências de diminuição na qualidade da informação contábil como Rodrigues (2012) e Paulo et al. (2013), o que se contradiz ao resultado aqui encontrado.

Trabalhando-se com as Variáveis Taxas de Câmbio e Taxas de Juros no Brasil, verificase que a variável Dummy apresentou o mesmo comportamento de antes da inserção dessas variáveis, ou seja, apresentou um coeficiente negativo (Ver Tabela 12), indicando diminuição no risco, mantendo, assim, o entendimento já consolidado.

Tabela 12 - Regressão Quantílica do Brasil - Beta (Variável Dependente) e Dummy, Taxa de Juros e Taxa de

\begin{tabular}{cccccc}
\multicolumn{7}{c}{ Câmbio (Variáveis Independentes) } \\
\hline País & Variável & Coeficiente & Erro Padrão & $t$-Statistic & Probabilidade \\
\hline 3 & DUMMYBR & -0.397717 & 0.079574 & -4.998061 & 0.0000 \\
3 & TC & 0.173586 & 0.046490 & 3.733856 & 0.0003 \\
3 & TJ & -0.014781 & 0.009119 & -1.620880 & 0.1068 \\
\hline
\end{tabular}

Fonte: Dados da pesquisa, $2016 .^{8}$

Para a China, os resultados são inconclusivos, considerando que, apesar de se ter uma diminuição no risco, ela é estatisticamente insignificante. Para Rodrigues e Niyama (2008), desde 1992 que a Contabilidade internacional passou a influenciar a Contabilidade na China, passando a adentrar características da Contabilidade ocidental e a ser discutidas questões de

\footnotetext{
${ }^{8}$ A Tabela Completa está no Apêndice A.
} 
proteção aos investidores, transparência das demonstrações contábeis e convergência, inclusive se discutindo questões de redução do custo de capital e do risco.

Nessa linha, pode-se remeter ao entendimento de que a não comprovação estatística da redução do risco no pós-IFRS possa ser atribuída ao fato de que os padrões chineses já haviam incorporado caraterísticas internacionais à sua Contabilidade, antes mesmo da adoção das IFRS, considerando que, segundo Rodrigues e Niyama (2008), a China necessitava captar recursos de investidores estrangeiros.

Barth, Landsman e Lang (2008) destacam a existência de incentivos que fizeram com que alguns países adotassem as normas internacionais voluntariamente ou mesmo deixassem as normas locais muito próximas dessas, de forma que, após a obrigatoriedade de sua adoção, as IFRS não ocasionaram impacto na qualidade da informação contábil, dadas as similadades entre normas domésticas e as IFRS, não permitindo notar mudanças dentro do quadro em análise.

Nesse sentido de resultados imprecisos, Zhou, Xiong e Ganguli (2009), por exemplo, ao investigar a adoção das IFRS na China, sugeriram melhoras na qualidade da informação contábil, mas, para alguns dos atributos testados, houve significância estatística e, para outros, não. Liu et al. (2011) e Qu, Fong e Oliver (2012), encontraram evidências de que a adoção das IFRS aumentou a qualidade da informação contábil, no entanto, Rodrigues (2012) não sustentou aumento da qualidade da informação contábil.

Com a inserção das variáveis de controle, a China, que já havia apresentado coeficiente negativo na primeira análise, porém insignificante, passa a apresentar significância, de forma que passa a ser possível inferir, então, que, no Pós-IFRS houve diminuição do risco (Ver Tabela 13). Sendo interessante destacar que a significância da Variável Dummy foi obtida, aliada com a significância das Variáveis Taxas de Juros e Taxas de Câmbio.

Nesse sentido, os resultados aqui encontrados ficam mais próximos dos obtidos por Liu et al. (2011) e Qu, Fong e Oliver (2012), que encontraram evidências de que a adoção das IFRS aumentou a qualidade da informação contábil.

É possível inferir, então, que, dentro de uma análise mais ampla, na qual novas variáveis foram acrescentadas ao modelo, depreendeu-se que a China obteve vantagem com o Pós-IFRS, na medida em que logrou melhorar a qualidade da sua informação contábil. Pode-se dizer que mesmo que as características do país no Pré-IFRS já tivessem em processo de reconhecimento da importância das novas normas contábeis, o Pós-IFRS possivelmente aumentou a confiabilidade nas informações contábeis. 
Tabela 13 - Regressão Quantílica da China - Beta (Variável Dependente) e Dummy, Taxa de Juros e Taxa de Câmbio (Variáveis Independentes)

\begin{tabular}{ccrrrr}
\hline País & Variável & Coeficiente & Erro Padrão & \multicolumn{1}{c}{$t$-Statistic } & Probabilidade \\
\hline 4 & DUMMYCH & -0.206667 & 0.032270 & -6.404294 & 0.0000 \\
4 & TC & 0.052539 & 0.021899 & 2.399103 & 0.0175 \\
4 & TJ & 0.242655 & 0.038939 & 6.231647 & 0.0000 \\
\hline
\end{tabular}

Fonte: Dados da pesquisa, $2016 .^{9}$

Para o Canadá, o resultado encontrado foi de acordo com o esperado, ou seja, verificouse que o coeficiente estudado foi negativo e estatisticamente significante (Ver Tabela 9), portanto, presume-se que houve melhora na qualidade da informação contábil. Nulla (2013) ressaltou que era evidente que a apresentação de relatórios financeiros sob IFRS é muito mais detalhado quanto à natureza dos GAAP canadenses (apesar de a estrutura ser baseada em princípios semelhantes às IFRS).

Assim, embora o Canadá seja um país caracterizado por uma Contabilidade com características fortes, acompanhando um modelo contábil no qual os usuários da informação contábil são focados, o nível de detalhamento proposto pelas IFRS pode ter sido o fator que provocou o resultado aqui encontrado, de forma que a adoção das IFRS trouxe ainda ganhos para o país, pois o poder de previsão dos números contábeis cresceu, assim como o conteúdo informacional.

No geral, pode-se dizer que Nulla (2013) encontrou que a qualidade da informação contábil no período pós-IFRS nas demonstrações contábeis das companhias canadenses foi afetada positivamente, corroborando com o resultado aqui em análise.

A presença das variáveis Taxas de Câmbio e Taxas de Juros fizeram com que a variável Dummy se tornasse insignificante, assim, embora o seu coeficiente tenha mantido o sinal negativo não se pode afirmar que houve diminuição no risco provada pelo Pós-IFRS (Ver Tabela 14). Tal resultado é passível de ser encontrado, dadas as características do Canadá que é um país que, no Pré-IFRS, já mantinha sua Contabilidade dentro de um modelo contábil voltado para os usuários da informação contábil, assim quando da adoção da IFRS e na presença de variáveis de controle, não se percebe uma resposta significativa. Tendo sido comentado por Nulla (2013) que o Canadá já apresentava relatórios financeiros em uma estrutura baseada em princípios semelhantes aos das IFRS.

\footnotetext{
${ }^{9}$ A Tabela Completa está no Apêndice A.
} 
Tabela 14 - Regressão Quantílica da Canadá - Beta (Variável Dependente) e Dummy, Taxa de Juros e Taxa de Câmbio (Variáveis Independentes)

\begin{tabular}{cccccc}
\hline País & Variável & Coeficiente & Erro Padrão & $t$-Statistic & Probabilidade \\
\hline 5 & DUMMYCAN & -0.012540 & 0.047724 & -0.262767 & 0.7930 \\
5 & TC & 0.085223 & 0.169891 & 0.501632 & 0.6166 \\
5 & TJ & 0.063404 & 0.009427 & 6.725888 & 0.0000 \\
\hline
\end{tabular}

Fonte: Dados da pesquisa, 2016. ${ }^{10}$

Para o Reino Unido, o resultado obtido foi estatisticamente significativo, porém, o efeito não se deu como esperado, orientando para o fato de que o risco aumentou (Ver Tabela 9), embora se deva considerar que esse aumento foi próximo de zero, onde praticamente se teria um efeito nulo. Nesse caso, o resultado indica que a qualidade da informação contábil não mudou no Pós-IFRS, corroborando os resultados encontrados por Gastón et al. (2010). O resultado em questão se justifica porque a Contabilidade do Reino Unido sempre teve parâmetros próximos ao que é apregoado nas IFRS. Inclusive ele é considerado como um importante membro do modelo contábil que valoriza a utilidade da informação para o usuário de maneira geral (GASTÓN et al., 2010).

Nessa linha, Barth, Landsman e Lang (2008) destacam que a aplicação das normas internacionais de Contabilidade está associada a uma maior qualidade da informação contábil, mas os efeitos sobre sistemas contábeis que já apresentavam características similares ao que está sendo implantando com as IFRS, tendem a ser irrisórios.

Iatridis (2010) acrescenta que o fato de o Reino Unido ser considerado um país que valoriza a essência econômica dos fatos contábeis, além de ter uma base diversificada de investidores e mecanismos fortes de proteção dos investidores, facilitou o processo de transição para as normas contábeis internacionais. Nesse caso, para o Reino Unido poder-se-ia dizer que a não alteração da qualidade da informação contábil era prevista pelas razões já apresentadas acima.

Estudos como os de Prather-Kinsey e Shelton (2005) e Jansson, Jonsson e Von Koch (2012), sugerem que, no pós-IFRS o Reino Unido presenciou um aumento da qualidade da informação contábil. Assim, pode-se inferir que a forma que a qualidade da informação contábil tem sido retomada tem apresentado efeitos diferenciados dentro do quadro do Pós-IFRS no Reino Unido.

Mesmo com a introdução de variáveis de controle (Taxas de Câmbio e Taxas de Juros), para o Reino Unido não houve alteração no comportamento da Dummy em relação ao risco, em

\footnotetext{
${ }^{10}$ A Tabela Completa está no Apêndice A.
} 
que continuou se obtendo um coeficiente positivo e estatisticamente significante (Ver Tabela 15), dando assim, continuidade e confirmação do que aqui já havia sido explanado quando se analisou esse país com a Dummy como única variável independente.

Tabela 15 - Regressão Quantílica do Reino Unido - Beta (Variável Dependente) e Dummy, Taxa de Juros e Taxa de Câmbio (Variáveis Independentes)

\begin{tabular}{llllll}
\hline País & Variável & Coeficiente & Erro Padrão & t-Statistic & Probabilidade \\
\hline 6 & DUMMYRU & 0.073944 & 0.023949 & 3.087525 & 0.0023 \\
6 & TC & 0.446439 & 0.161028 & 2.772429 & 0.0062 \\
6 & TJ & -0.011094 & 0.013702 & -0.809637 & 0.4192 \\
\hline
\end{tabular}

Fonte: Dados da pesquisa, 2016. ${ }^{11}$

A Itália obteve um coeficiente positivo estatisticamente significante (Ver Tabela 9), acompanhando a ideia de que o risco aumentou (ou não alterou, dada a proximidade de zero). Nesse caso, não se poderia dizer que a qualidade da informação contábil na Itália teve ganho no período de Pós-IFRS. Esperava-se que o ganho proporcionado pelas IFRS fosse considerável, se tendo a expectativa de que houvesse aumento na qualidade da informação contábil e ganho para os investidores, porém, com os resultados aqui encontrados, não se pode dizer que tais perspectivas foram confirmadas.

Essa linha de raciocínio é montada, uma vez que a Contabilidade da Itália se caracteriza dentro de uma configuração voltada para a legislação, com ênfase em regras fiscais, além de ser consideravelmente conservadora, tendo grande foco na proteção dos credores e nos recursos provenientes de instituições financeiras. Portanto, a estrutura em que a Contabilidade se desenvolvia no Pré-IFRS era antagônica ao que era proposto. Assim, se esperava diminuição do risco e, portanto, aumento da qualidade da informação contábil no pós-IFRS.

Considerando que a Itália estava junto do grupo de países da Europa que primeiro entrou no processo de convergência internacional, esperava-se que a adoção das IFRS, em termos de aumento da qualidade da informação contábil, já tivesse em posição de completude. No entanto, dadas as evidências encontradas nesse estudo, infere-se que, ou o processo de aprendizagem ainda não atingiu sua plenitude ou, em termos da vertente aqui explorada, o alcance que se esperava não se concretizou.

Porém, não se pode deixar de inferir que, para países com longos anos de experiência cuja Contabilidade possui intensas caraterísticas de conservadorismo e de apego a regras, o efeito da adoção das IFRS pode ser tardio, pois, a depender da expectativa do usuário, a qualidade de uma normatização flexível pode ser posta em xeque.

\footnotetext{
${ }^{11}$ A Tabela Completa está no Apêndice A.
} 
Dentro da vertente de value-relevance abordada por Paglietti (2009), os resultados esperados para o Pós-adoção da IFRS foram alcançados, ou seja, houve melhoria na qualidade da informação contábil, o que não foi confirmado nesta pesquisa. Por outro lado, Palea (2014), trabalhando dentro da mesma vertente de qualidade da informação contábil proposta por Paglietti (2009), não encontrou incremento de informação relevante comparando com as normas locais, não se deparando com o aumento da qualidade da informação contábil, estando, portanto, fortalecido pelas evidências encontradas neste estudo.

Para a Itália, conforme pode ser visualizado na Tabela 16, as variáveis Taxas de Câmbio e Taxas de Juros, quando incluídas no modelo, não provocaram alteração no sinal do coeficiente da variável Dummy em relação ao risco, tendo continuado positivo e estatisticamente significante (Ver Tabela 16). As inferências então realizadas para esse país são corroboradas.

Tabela 16 - Regressão Quantílica do Itália - Beta (Variável Dependente) e Dummy, Taxa de Juros e Taxa de Câmbio (Variáveis Independentes)

\begin{tabular}{cccccc}
\hline País & Variável & Coeficiente & Erro Padrão & $t$-Statistic & Probabilidade \\
\hline 7 & DUMMYITAL & 0.062281 & 0.030771 & 2.024028 & 0.0445 \\
7 & TC & -0.493572 & 0.225466 & -2.189123 & 0.0299 \\
7 & TJ & -0.061281 & 0.013742 & -4.459396 & 0.0000 \\
\hline
\end{tabular}

Fonte: Dados da pesquisa, 2016. ${ }^{12}$

A França apresentou coeficiente positivo, mas bem próximo de zero (Ver Tabela 9). O resultado encontrado para a França não se mostrou estatisticamente significativo (Ver Tabela 9). Diante disso, visualiza-se que o efeito do Pós-IFRS na França, nas condições aqui investigadas, foi nulo. Assim, nesse contexto, as IFRS não teriam alterado a qualidade da informação contábil na França.

A França é um país que, durante um longo tempo, teve sua Contabilidade com ênfase na legislação tributária, sendo muito influenciada pelo governo, tendo como fonte principal de recursos às instituições financeiras. Para países com essa característica, esperava-se que houvesse aumento da qualidade da informação contábil com a inserção no processo de convergência internacional (CHIHA; TRABELSI; HAMZA, 2013), o que não foi comprovado pelos dados analisados na presente pesquisa.

O fato de não se encontrar efeito no Pós-IFRS na França é inesperado, principalmente, porque as regras contábeis francesas foram consideradas significativamente diferentes das IFRS (CORMIER; DEMARIA; LAPOINTE-ANTUNES, 2012; CHIHA; TRABELSI; HAMZA, 2013), o que implicaria em observação de impacto com a adoção das IFRS e que as incertezas

\footnotetext{
${ }^{12}$ A Tabela Completa está no Apêndice A.
} 
quanto à confiabilidade da informação contábil já deveriam ter diminuído. No entanto, o fato de as evidências encontradas nesse estudo apontarem em direção contrária pode estar atrelado a outras características intrínsecas ao país que muitas vezes se sobrepõe, principalmente considerando que a adoção das IFRS foi bastante criticada no País.

Cormier, Demaria e Lapointe-Antunes (2012) destacou que a França se apresentou como um dos países da Europa mais relutantes em mudar, dada a sua forte tradição de Contabilidade fiscal, o que contrasta com a prioridade à essência econômica das transações financeiras proposta pelas IFRS. Nesse caso, essa poderia ser uma justificativa para o resultado aqui encontrado, considerando que existe uma certa dificuldade do processo de adoção das IFRS surtir efeitos em países com essas características que se mostram resistentes em abrir mão do conservadorismo e da fixação na utilização de regras, se preocupando com o prejuízo da confiabilidade da informação contábil. Assim, é possível que a incerteza quanto à melhoria trazida com a adoção das IFRS ainda esteja presente na França, fazendo com que o risco não tenha diminuído e, portanto, a qualidade da informação contábil não tenha sido alterada.

Com relação à França, Cormier, Demaria e Lapointe-Antunes (2012) analisaram diferentes vertentes em seu trabalho e, ao analisar o gerenciamento de resultados, ele aumentou, indicando influência negativa na qualidade da informação contábil para o período pós-IFRS. No entanto, Boumediene, Boumediene e Nafti (2014) ao investigar a mesma vertente, achou diminuição do gerenciamento de resultado, portanto, aumento da qualidade da informação contábil.

Nafti, Boumediene e Boumediene (2013) e Chiha, Trabelsi e Hamza (2013) conseguiram encontrar aumento na qualidade da informação contábil, que seria o resultado esperado para uma Contabilidade com as características da França. Os autores encontraram que o conteúdo da informação contábil do lucro foi maior no pós-IFRS. Assim, os resultados encontrados para as investigações do Pós-IFRS na França se mostram divergentes.

O comportamento da variável Dummy em relação ao Beta não se alterou após se acrescentar, ao modelo, as variáveis Taxas de Juros e Taxas de Câmbio, de forma que, para esse país, não se encontrou significância estatística para se afirmar que o Pós-IFRS ocasionou influência sobre o risco (Ver Tabela 17). Portanto, as inferências realizadas quando da análise do primeiro modelo, se mantêm válidas. 
Tabela 17 - Regressão Quantílica da França - Beta (Variável Dependente) e Dummy, Taxa de Juros e Taxa de Câmbio (Variáveis Independentes)

\begin{tabular}{cccccc}
\hline País & Variável & Coeficiente & Erro Padrão & $t$-Statistic & Probabilidade \\
\hline 8 & DUMMYFRAN & 0.019395 & 0.037486 & 0.517387 & 0.6055 \\
8 & TC & 0.274300 & 0.281404 & 0.974755 & 0.3310 \\
8 & TJ & 0.029447 & 0.015956 & 1.845454 & 0.0667 \\
\hline
\end{tabular}

Fonte: Dados da pesquisa, $2016 .^{13}$

A Nova Zelândia apresentou coeficiente positivo, embora não estatisticamente significante, além de estar próximo de zero (Ver Tabela 9), de forma que não se pode inferir efeito da adoção das IFRS no risco.

A Nova Zelândia no Pré-IFRS já era um país que primava pela liberdade das firmas na elaboração dos seus relatórios financeiros, propondo uma visão justa e verdadeira, tendo como prioridade o entendimento dos acionistas e priorizando a proteção do investidor. Assim, a inserção no processo de convergência internacional, praticamente não muda a forma de se praticar Contabilidade nesse país. Dentro desse contexto, presume-se que os achados dessa pesquisa demonstram que não houve mudança na confiabilidade que se tinha nas normas contábeis, o que pode estar atrelado ao fato de que a qualidade da informação contábil já era algo focado em torno do processo de elaboração das informações contábeis, não tendo havido grandes alterações no Pós-IFRS.

Kabir, Laswad e Islam (2010) destacam que, desde meados dos anos 1990, houve iniciativas no sentido de harmonizar os padrões locais da Nova Zelândia com as IFRS, o que corrobora a ideia de que o efeito no Pós-IFRS seria nulo. No entanto, os autores reforçam que ainda cabe pesquisa empírica, pois as IFRS ainda apresentam diferenças importantes em relação às normas locais.

Os resultados achados na pesquisa de Kabir, Laswad e Islam (2010), indicaram que a qualidade da informação contábil ao se estudar a capacidade de previsão da informação futura e o gerenciamento de resultados não melhoraram no pós-IFRS. O gerenciamento de resultado foi, inclusive, maior no Pós-IFRS e não houve melhora na qualidade da previsão dos fluxos de caixa futuros. Rainsbury, San Diego e Walker (2010) investigaram a associação entre o lucro e o valor de mercado das ações e o value-relevance dos números contábeis, antes e depois da IFRS, não encontrando evidências do aumento na qualidade da informação contábil no PósIFRS na Nova Zelândia. Assim, considerando-se a qualidade da informação contábil no geral, esses achados são fortalecidos pelas evidências encontradas nesta pesquisa.

\footnotetext{
${ }^{13}$ A Tabela Completa está no Apêndice A.
} 
A insignificância estatística demonstrada quando se analisou o Beta quando influenciado pelo Pós-IFRS continuou ao se inserir variáveis de controle (Ver Tabela 18), assim, embora na nova análise o coeficiente tenha passado a ser negativo, o fato de não ter sido significante torna as inferências realizadas para esse país ainda irrefutáveis.

Tabela 18 - Regressão Quantílica da Nova Zelândia - Beta (Variável Dependente) e Dummy, Taxa de Juros e Taxa de Câmbio (Variáveis Independentes)

\begin{tabular}{cccccc}
\hline País & Variável & Coeficiente & Erro Padrão & $t$-Statistic & Probabilidade \\
\hline 9 & DUMMYNZ & -0.027562 & 0.035000 & -0.787478 & 0.4321 \\
9 & TC & -1.696034 & 0.279251 & -6.073499 & 0.0000 \\
9 & TJ & 0.065099 & 0.008458 & 7.696524 & 0.0000 \\
\hline
\end{tabular}

Fonte: Dados da pesquisa, $2016 .^{14}$

Para a Rússia, não houve efeito no risco no Pós-IFRS, pois o coeficiente apresentou sinal positivo, mas bem próximo de zero, além de não apresentar significância estatística (Ver Tabela 9).

Na realidade, o processo de adoção das IFRS na Rússia ainda é muito recente, o que poderia ser uma possível justificativa para ainda não se alcançar um efeito do processo de adoção nos dados analisados. Segundo Borker (2012), o processo de adoção das normas contábeis internacionais representou para a Rússia um reforço na reputação financeira perante o mundo e esperava-se que houvesse contribução para atrair o capital necessário ao país.

Inclusive, Generalova e Sokolova (2014) discorrem sobre um processo de transição de um sistema contábil de uma economia planificada para uma economia de mercado, destacando, ainda, que a ideia de adotar normas internacionais visaria que o sistema contábil do país alcançasse um novo nível qualitativo, mudando o conceito da Contabilidade. Espera-se que o processo de adoção das IFRS melhore a qualidade da informação contábil devido a um grau mais elevado de responsabilidade.

O resultado esperado para adoção das IFRS na Rússia se dá em torno do aumento da confiança e transparência das informações contábeis, uma vez que estas, antes da adoção das IFRS, pouco se orientavam para a substância econômica das operações, tendo uma grande orientação da legislação tributária (BORKER, 2012). Dessa forma, o resultado aqui encontrado contrariou o esperado, mas, é possível que tal ocorrência possa ser atribuída ao processo recente de inserção das IFRS na Rússia. Nesse sentido, Borker (2012) frisa que esse mundo mudou radicalmente, mas as atitudes das pessoas mudam mais lentamente.

\footnotetext{
${ }^{14}$ A Tabela Completa está no Apêndice A.
} 
No caso da Rússia, quando se analisou o modelo com variáveis de controle, a variável Dummy passou a ser significante (Ver Tabela 19), embora o sinal do coeficiente tenha continuado positivo. Nesse sentido, verifica-se que, nesse país, tem-se a indicação de que, no Pós-IFRS, o risco aumentou, não se considerando ganho na qualidade da informação.

Nesse caso, as variáveis de controle trouxeram significância para a Dummy, no entanto, o efeito caracteriza inferências no sentido de perda da qualidade da informação contábil. Tal resultado pode ser atribuído ao fato de que a Rússia viviencia um processo de transição de um sistema contábil caracterizado pela forte presença do conservadorismo, de forma que a adoção de novas normas contábeis traz, consigo, o aumento da incerteza quanto a efetividade das novas práticas, ainda se questionando, portanto, se de fato, se terá ganho em termos do conteúdo informacional da Contabilidade.

Tabela 19 - Regressão Quantílica da Rússia - Beta (Variável Dependente) e Dummy, Taxa de Juros e Taxa de Câmbio (Variáveis Independentes)

\begin{tabular}{cccccc}
\hline País & Variável & Coeficiente & Erro Padrão & $t$-Statistic & Probabilidade \\
\hline 10 & DUMMYRUS & 0.210865 & 0.094883 & 2.222362 & 0.0275 \\
10 & TC & -0.020112 & 0.022533 & -0.892543 & 0.3733 \\
10 & TJ & 0.018858 & 0.008031 & 2.348181 & 0.0200 \\
\hline
\end{tabular}

Fonte: Dados da pesquisa, 2016. ${ }^{15}$

A África do Sul apresentou um dos coeficientes mais distantes de zero, com efeito positivo e estatisticamente significativo (Ver Tabela 9). Esse achado indica que o risco para esse país aumentou, indicando uma propensa baixa na qualidade da informação contábil no PósIFRS.

A África do Sul é um país que se caracteriza por possuir uma Contabilidade desprendida de regras legais, de forma que suas companhias têm mais liberdade na elaboração de seus relatórios financeiros, sendo estes inspirados pelo princípio da visão justa e verdadeira (true and fair value), forma que tende a ser mais clara para o entendimento dos acionistas. Diante disso, seria possível que o efeito das IFRS na Contabilidade da África do Sul fosse nulo, como já visto em alguns dos países aqui em análise. Inclusive, Ames (2013) destacou que, antes da adoção das IFRS na África do Sul, a qualidade das demonstrações contábeis se mostrava relativamente alta.

Ossip (2011), também colocou que a África do Sul oferecia um cenário interessante, pois, desde 1995, houve iniciativas no sentido do enquadramento com as normas internacionais, chegando-se a se iniciar o processo de adoção das IFRS, sem modificação.

\footnotetext{
${ }^{15}$ A Tabela Completa está no Apêndice A.
} 
No entanto, tal fator pode não ter sido significativo na África do Sul, considerando, principalmente, a forma como se deu a decisão de inclusão no processo de convergencia internacional das normas contábeis. A África do Sul foi um dos poucos países que não passaram por um processo de aprovação, uma vez que a bolsa de valores impôs a adoçaõ das IFRS, o que representa um caso raro dentre os países que entraram no processo, pois, na maioria, os governos, por razões de soberania, sentiram a necessidade de passar por um processo de aprovação (IFRS, 2011).

No resultado aqui encontrado, essa forma de adoção pode ter aumentado a incerteza diante dos benefícios a serem alcançados com a inserção no processo de convergência e assim, o risco aumentou, compromentendo, deste modo, a qualidade da informação contábil. Nessa linha, Ames (2013) ressalta, ainda, que a adoção relativamente precoce da África do Sul foi a única entre seus pares, retomando a possível situação de incerteza quanto aos benefícios aqui em inferência.

Ossip (2011) destaca que, para os participantes do mercado em geral, a percepção da adoção das IFRS foi alterada negativamente, como resultado da aplicação de normas únicas para todos os países, sendo esse um ponto de vista inadequado sobre a adoção de um conjunto de regras contábeis para as empresas Sul-Africanas. Os participantes do mercado ainda estão sob a impressão de que as IFRS não podem simplesmente ser adotadas pela África do Sul sem ajustá-las às circunstâncias específicas do país.

Alinhado com o resultado aqui encontrado, Ames (2013), ao investigar a qualidade das informações contábeis antes e depois da adoção das IFRS, através do value-relevance, encontrou evidências de que a qualidade dos lucros não é melhorada significativamente no pósadoção. Da mesma forma, Ossip (2011) encontrou que o value-relevance das informações contábeis sob normas locais é relativamente maior que o sob IFRS, também apontando redução na qualidade da informação contábil.

Conforme a Tabela 20, para a África do Sul o fato de se ter acrescentado variáveis de controle ao modelo, não modificaram o resultado já obtido quando a variável Dummy foi testada isoladamente, de forma que o coeficiente continuou positivo e estatisticamente significante. Dessa forma, as inferências realizadas se mantiveram evidentes. 
Tabela 20 - Regressão Quantílica da África do Sul - Beta (Variável Dependente) e Dummy, Taxa de Juros e Taxa

\begin{tabular}{cccccc}
\multicolumn{7}{c}{ de Câmbio (Variáveis Independentes) } & & & \\
\hline País & Variável & Coeficiente & Erro Padrão & $t$-Statistic & Probabilidade \\
\hline 11 & DUMMYAS & 0.498938 & 0.143454 & 3.478028 & 0.0006 \\
11 & TC & 0.013183 & 0.033179 & 0.397335 & 0.6916 \\
11 & TJ & 0.017090 & 0.023836 & 0.717007 & 0.4743 \\
\hline
\end{tabular}

Fonte: Dados da pesquisa, $2016 .^{16}$

De forma geral, não se consegue visualizar um padrão de comportamento do risco diante da incorporação das IFRS nos diversos países. Foi possível verificar países com uma Contabilidade considerada como fraca no Pré-IFRS e que não se observou melhoria na qualidade da informação contábil, assim como houve países que antes já tinham uma Contabilidade considerada forte e que se esperava comportamento nulo do risco, mas que observou-se alterações.

Em resumo, trabalharam-se os resultados da primeira relação do Beta com a Dummy na Tabela 21.

Tabela 21 - Beta (Variável Dependente) e Dummy (Variável Independente)

\begin{tabular}{ccc}
\hline País & Sinal & Significância \\
\hline Austrália & Positivo & $\checkmark$ \\
Alemanha & Negativo & $\checkmark$ \\
Brasil & Negativo & $\checkmark$ \\
China & Negativo & \\
Canadá & Negativo & $\checkmark$ \\
Reino Unido & Positivo & $\checkmark$ \\
Itália & Positivo & $\checkmark$ \\
França & Positivo & \\
Nova Zelândia & Positivo & \\
Rússia & Positivo & $\checkmark$ \\
África do Sul & Positivo & \\
\hline
\end{tabular}

Fonte: Dados da pesquisa, 2016.

Da mesma forma, $\mathrm{Na}$ Tabela 22, se apresenta o resumo dos resultados da do Beta com a Dummy e as variáveis de controle.

\footnotetext{
${ }^{16}$ A Tabela Completa está no Apêndice A.
} 
Tabela 22 - Beta (Variável Dependente) e Dummy, Taxas de Juros e Taxas de Câmbio (Variável Independente)

\begin{tabular}{ccc}
\hline País & Sinal & Significância \\
\hline Austrália & Positivo & $\checkmark$ \\
Alemanha & Negativo & $\checkmark$ \\
Brasil & Negativo & $\checkmark$ \\
China & Negativo & $\checkmark$ \\
Canadá & Negativo & \\
Reino Unido & Positivo & $\checkmark$ \\
Itália & Positivo & $\checkmark$ \\
França & Positivo & \\
Nova Zelândia & Negativo & \\
Rússia & Positivo & $\checkmark$ \\
África do Sul & Positivo & $\checkmark$
\end{tabular}

Fonte: Dados da pesquisa, 2016.

Nesse sentido, Soderstrom e Sun (2007) afirmaram que as diferenças entre países no que se refere à qualidade contábil provavelmente permanecerão após a implementação das IFRS, dado que esta é afetada pelo sistema jurídico, fatores culturais e políticos, bem como pelos incentivos aos relatórios financeiros, de forma que o uso de um único conjunto de normas contábeis não conduz necessariamente a uma alta qualidade da informação para todos os ambientes econômicos. A qualidade da Contabilidade é um conceito amplo, com várias dimensões, de modo que a adoção de padrões de alta qualidade pode ser uma condição necessária para informações de alta qualidade, mas não impreterivelmente suficiente.

\subsection{Regressão Logística}

No sentido de se trabalhar a variável binária, onde " 0 " é a ausência da IFRS e "1" é a presença da IFRS, se buscou encontrar variáveis independentes que estivessem relacionadas como fatores de qualidade da informação contábil. Com isso, além de se buscar a relação com o Beta que aqui vem sendo estudado, se buscou também utilizar da análise fatorial para que um indicador contábil fosse criado e assim, fosse incluinda informação contábil como possível explicação direta da inclusão da linha de tempo do estudo sem IFRS e com IFRS.

O método de Análise Fatorial (AF) para o estudo em uso, se buscou identificar o melhor conjunto de variáveis que se integrava ao modelo. Assim, quando se executou a Análise Fatorial com todas as variáveis inicialmente selecionadas, a medida MSA apresentada pelo teste KMO foi muito baixa para algumas variáveis, mostrando-se menor que 0,7 (Ver tabela 23), portanto, ter-se-ia um método sem aplicabilidade. 
Tabela 23 - KMO com todas as variáveis selecionadas

Kaiser-Meyer-Olkin Measure of Sampling Adequacy.

Bartlett's Test of Sphericity

df

Sig.

0,000

Fonte: Dados da PesquisaPesquisa, 2016

No caso do teste de Bartlett houve indicação para aplicação da Análise Fatorial, uma vez que existiu significância estatística (Ver tabela 23). Mas, é preferível aumentar o poder de explicação dos fatores retirando algumas das variáveis da análise, então, se excluiu aquelas variáveis com MSA menor que 0,3, no intuito de estabelecer uma melhor associação entre as variáveis analisadas. De forma que se conseguiu, então, alcançar um MSA mediano, maior que 0,7 (Ver tabela 24), passível de um bom modelo de Análise Fatorial. O teste de esfericidade continuou validando a utilização da Análise Fatorial (significância < 0,05).

$\mathrm{Na}$ segunda tentativa, apesar de algumas variáveis ainda apresentarem pouca relação com os fatores, a maioria das variáveis conseguiu um poder de explicação alto, considerando todos os fatores obtidos (comunalidades) (Ver Apêndice B-3).

A análise da matriz de correlação antiimagem também remete a uma boa Análise Fatorial, pois trouxe, em sua diagonal, valores considerados apropriados, sendo em praticamente sua totalidade maior que 0,5, abrindo exceções para MSA acima de 0,44, dado que poderia se ter uma observação mais ampla da correlação entre as variáveis (Ver Apêndice B-10).

O grau de explicação atingido pelos 4 fatores, aqueles com Autovalores (Eigenvalues) maiores que 1, calculados pela Análise Fatorial, foi de 91,568\% (Ver tabela 24), portanto, o modelo consegue explicar quase $92 \%$ da variância dos dados originais, o que é considerado muito bom.

O Gráfico 3 confirma, através do critério do autovalor (Eigenvalue > 1), a extração (qualificação) de 4 fatores, sendo esse o número de fatores ótimos que podem ser extraídos antes que a quantia de variância única comece a dominar a estrutura de variância comum, conforme referendado por Hair Júnior et al. (2009).

O Gráfico 3 também ratifica que o $F_{1}$ é o fator que explica mais da metade da variância dos dados originais, estando contidas nele a maioria das variáveis que apresentaram fortes cargas fatoriais (Maiores que 1). 
Gráfico 3 - Autovalor para o critério de teste Scree

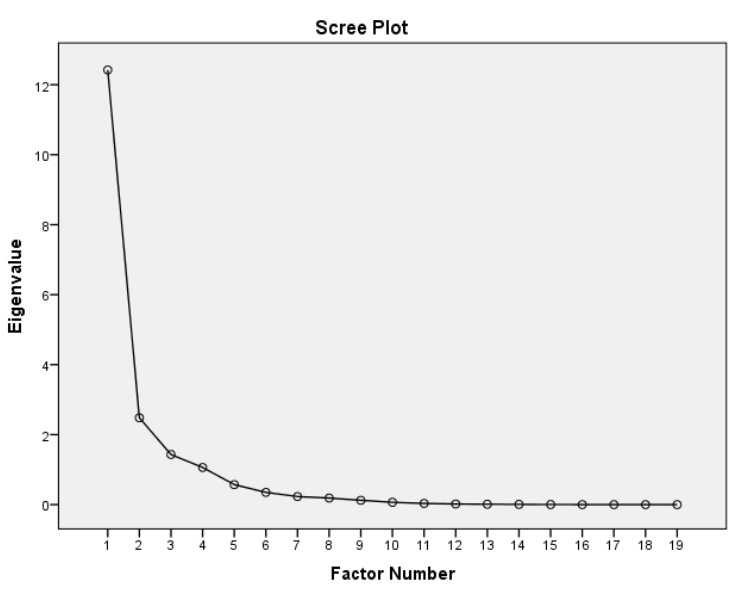

Fonte: Dados da pesquisa, 2016.

Não foi utilizada nenhuma rotação, considerando o fato de que as cargas fatoriais já estavam bastante elevadas ou muito pequenas e também porque um único fator explica a maior parte da variabilidade total não ocorrendo dificuldades para interpretação que o Fator 1 (F1) como responsável pela maior parte da variância explicada, 65,4\% (Ver tabela 24).

Tabela 24 - Medidas estatísticas para a validação da Análise Fatorial do instrumento com o Método das Componentes Principais (Principal Conponent Analysis)

\begin{tabular}{cccc}
\hline Fatores & Autovalores & $\begin{array}{c}\text { \% Variação } \\
\text { explicada }\end{array}$ & $\begin{array}{c}\text { \% Var. explicada } \\
\text { acumulada }\end{array}$ \\
\hline Fator 1 & 12,422 & 65,380 & 65,380 \\
\hline Fator 2 & 2,482 & 13,064 & 78,444 \\
\hline Fator 3 & 1,432 & 7,535 & 85,979 \\
\hline Fator 4 & 1,062 & 5,589 & 91,568 \\
\hline Teste da esfericidade de Bartlett & Estatística & 9760,705 \\
\hline \multicolumn{2}{r}{ Kaiser-Meier-Olkin (KMO) } & Valor-P & $<0,001$ \\
\hline Medida de adequação amostral (MSA) & & 0,733 \\
\hline
\end{tabular}

Fonte: Dados da pesquisa, 2016.

A Tabela 24 mostra, portanto, o resultado da aplicação da Análise Fatorial com o método Fatoração dos Eixos Principais que necessitou apenas de 11 interações para obter as estimativas dos parâmetros do modelo AF. Pode-se perceber que um fator explica aproximadamente 65,38\% da variabilidade contida nos dados; tendo sido o modelo AF considerado aplicável e adequado aos dados em questão. Assim, pode-se considerar a estrutura unidimensional (apenas um fator) como representativo da variabilidade dos dados e, portanto, um índice será construído com a expressão do $\mathrm{F}_{1}$, sendo uma combinação linear das variáveis descrito na Equação 24. 


$$
F_{1}=0,968 X 1+0,965 X 2+\ldots+0,144 X 19
$$

Em geral, converte-se o índice $\mathrm{F}_{1}$ em uma escala de 0 a 100 através da transformação expressa na Equação 25.

$$
\text { Índice }=\left(\mathrm{F}_{1}-\operatorname{mínimo}\left\{\mathrm{F}_{1}\right\}\right) /\left(\text { máximo }\left\{\mathrm{F}_{1}\right\}-\operatorname{mínimo}\left\{\mathrm{F}_{1}\right\}\right) * 100
$$

Dessa forma, se tem o cálculo do Índice demonstrado pelo modelo AF, contendo as variáveis com maiores cargas fatoriais e relevantes à pesquisa (Ver Tabela 25) de tal modo que nesse Índice estão as variáveis que apresentam alta correlação, pois a tendência é de que as variáveis altamente correlacionadas compartilhem o mesmo fator.

É válido salientar que as variáveis contábeis estudadas foram coletadas nos diferentes países seguindo a linha de tempo que inclui o Pré e Pós-IFRS, de forma que não existe um foco para variáveis específicas, mas para o todo, pois sejam variáveis patrimoniais ou de resultado, sofreram influência com a adoção das IFRS. Assim, o Índice aqui é contábil, sem restrição de variáveis.

\begin{tabular}{|c|c|c|c|c|c|}
\hline \multirow[b]{2}{*}{ Cod. } & \multirow[b]{2}{*}{ Variável } & \multicolumn{4}{|c|}{ Fator } \\
\hline & & 1 & 2 & 3 & 4 \\
\hline $\mathrm{X} 1$ & BS_CUR_ASSET_REPORT & ,968 &,- 128 &,- 198 &,- 020 \\
\hline $\mathrm{X} 2$ & BS_CUR_LIAB & ,965 &,- 078 &,- 167 &,- 112 \\
\hline $\mathrm{X} 3$ & BS_NET_FIX_ASSET & ,935 &,- 143 &,- 215 &, 023 \\
\hline $\mathrm{X} 4$ & BS_TOT_ASSET & ,981 &,- 075 &,- 067 &,- 009 \\
\hline $\mathrm{X} 5$ & BS_TOT_LIAB2 & ,981 &,- 060 &,- 044 &,- 028 \\
\hline $\mathrm{X} 6$ & CF_CASH_FROM_OPER & ,877 &, 188 & ,234 &,- 297 \\
\hline $\mathrm{X} 7$ & CF_FREE_CASH_FLOW & ,786 & ,059 & ,274 &,- 330 \\
\hline $\mathrm{X} 8$ & EBIT & ,928 &, 184 & , 197 &, 182 \\
\hline X9 & EBITDA & ,976 & ,089 & 020 &, 063 \\
\hline $\mathrm{X} 10$ & ENTERPRISE_VALUE &,- 264 & ,882 & ,083 &,- 069 \\
\hline $\mathrm{X} 11$ & IS_EPS & ,368 &,- 426 &, 515 &,- 221 \\
\hline $\mathrm{X} 12$ & IS_INC_TAX_EXP & ,781 & ,542 & ,074 & ,233 \\
\hline $\mathrm{X} 13$ & IS_OPER_INC & ,936 & ,255 & 076 & 229 \\
\hline $\mathrm{X} 14$ & PX_LAST &,- 082 &,- 442 & ,635 & 212 \\
\hline $\mathrm{X} 15$ & RETURN_COM_EQY &,- 190 & ,701 &, 273 & 049 \\
\hline $\mathrm{X} 16$ & SALES_REV_TURN & ,991 &,- 016 &,- 097 &,- 020 \\
\hline $\mathrm{X} 17$ & SHORT_AND_LONG_TERM_DEBT & ,938 &, 036 &, 127 &,- 022 \\
\hline $\mathrm{X} 18$ & TOTAL_EQUITY & ,943 &,- 169 &,- 211 &, 113 \\
\hline $\mathrm{X} 19$ & WORK_CAP_GROWTH &, 144 &,- 266 &, 155 &, 423 \\
\hline
\end{tabular}

Tabela 25 - Cargas fatoriais para os quatro fatores do modelo de Análise Fatorial

Fonte: Dados da pesquisa, 2016. 
As variáveis X2, X3, X4, X5, X16 e X17 apresentaram carga fatorial bem próxima de 1 (Ver Tabela 25), o que remete à sua alta correlação com o modelo, de forma que sua participação no índice encontrado é intensa. Tem-se, portanto, a ideia de que a variação do comportamento do Ativo Total; Passivo Total; Empréstimos e Financiamentos de curto e longo prazo; e do Total das Receitas, são variáveis importantes ao se falar do impacto provocado pela adoção das IFRS nos países em estudo.

Pode-se dizer que essa ideia corrobora os estudos de Terzi, Oktem e Sen (2013), nos quais variáveis como ativo imobilizado, capital de giro, passivo circulante e patrimônio líquido foram investigadas em empresas na Turquia, de forma comparativa entre GAAP local e as IFRS, encontrando diferença estatística significativa.

No estudo de Nascimento e Silva (2012), embora tenha sido de cunho mais específico por ter se restringido a um país, também encontrou evidências de que variáveis como Ativo total e Endividamento apresentaram diferenças estatísticas significativas ao se analisar se houve alteração no período pós-IFRS.

Callao, Jarne e Laínez (2007) investigaram o impacto da adoção das IFRS nas demonstrações financeiras de empresas na Espanha, encontrando diferença estatisticamente significativa entre o padrão IFRS e o padrão local. Especialmente, observou-se que os passivos totais, passivos de longo prazo, caixa e equivalentes de caixa e patrimônio líquido foram afetados significativamente na transição para as IFRS. Além disso, se identificou também que os valores contábeis diferem significativamente dos valores de mercado em IFRS e sob normas espanholas.

Ainda na linha de detecção de relevantes cargas fatoriais, variáveis como X1, X6, X7, X8, X9, X12, X13 e X18, são consideradas como relevantes para a pesquisa em análise (Ver Tabela 25). Resultado esse que pode se remeter ao levantado por Macedo et al. (2011) quando encontrou maior conteúdo informacional para o fluxo de caixa das operações ao analisar o efeito da adoção das normas internacionais no ambiente brasileiro. Machado, Silva Filho e Callado (2014) investigaram a capacidade informativa do lucro contábil no Pré e Pós adoção das IFRS no Brasil, utilizando de variáveis como fluxo de caixa operacional, lucro operacional/EBIT, encontrando resultados que revelaram aumento da capacidade explicativa dessas variáveis no período pós-IFRS.

Variações de impostos e variações de ativo corrente também são variáveis absorvidas pelo modelo estudado em Machado, Silva Filho e Callado (2014), no sentido de verificar a relevância dessas informações no aumento do poder explicativo dos fluxos de caixas futuros, tendo sido testada a capacidade explicativa do lucro líquido e do fluxo de caixa operacional 
combinados com os accruals. Os resultados revelaram um aumento da capacidade explicativa das variáveis trabalhadas durante o período pós-convergência.

Kabir, Laswad e Islam (2010), ao analisarem o impacto da adoção das IFRS sobre as contas das empresas da Nova Zelândia, encontraram que os ativos totais, passivos totais, lucro líquido e patrimônio líquido foram significativamente maiores do que os GAAPs locais.

Hung e Subramanyam (2007), em pesquisas realizadas com empresas alemãs, concluíram que a variável patrimônio líquido foi mais relevante quando na presença das normas internacionais, o que ocorreu também com Kadri, Aziz e Ibrahim (2009) que encontraram que o poder explicativo do patrimônio líquido aumentou após a mudança de padrão contábil para IFRS, na Malásia, uma vez que essa variável só se mostrou relevante com as normas internacionais.

Barth, Landsman e Lang (2008) investigaram variáveis como passivo total, receitas, ativo total, patrimônio líquido em 21 países que participaram do processo de convergência das normas internacionais e conseguiram verificar aumento na relevância das informações contábeis.

Embora as variáveis X10, X11, X14, X15 e X19 tenham apresentado uma carga fatorial baixa (Ver Tabela 25), elas estão interagindo com as variáveis que compõe o índice que determina que as variáveis contábeis em estudo sofreram impacto quando submetidas à presença das IFRS.

$\mathrm{Na}$ linha dessas variáveis, confirmando os resultados aqui obtidos, Morais e Curto (2009) investigaram 14 países e encontraram que, com a presença das IFRS, variáveis como valor de mercado das ações e lucro líquido por ação, tiveram seu value-relevance aumentado.

Macedo, Machado e Machado (2011) encontraram aumento do conteúdo informacional para o Lucro Líquido por Ação, após investigar a relevância da informação contábil de períodos anteriores e seguintes à primeira fase do processo de convergência das normas internacionais de Contabilidade no Brasil.

Sovbetov (2015), em estudo realizado no Reino Unido, encontrou diferença significativa de $5 \%$ para o ROE, concluindo que esse índice foi afetado pela adoção das IFRS.

Assim, o índice encontrado a partir da análise fatorial traz um comportamento variado com relação às variáveis contábeis, abrangendo contas patrimoniais e de resultado, demonstrando que, após a adoção das IFRS pelos diferentes países, houve uma resposta ampla das variáveis contábeis, não se restringindo a poucos itens, mas a uma grande gama daqueles que melhor definem a situação patrimonial atual e futura da entidade. 
Os índices foram estudados também em termo da variação de seu comportamento por país e de acordo com a ausência ou presença das IFRS. Conforme o Teste t (aplicado por se tratar de dados normais (Ver Apêndice B-6, B-7, B-8 e B-9)), os países quando em análise individuais apresentaram diferença estatística significativa, assim como em conjunto (Ver Tabela 26). Isso significa que, com a presença das IFRS, o índice em análise apresentou variação no comportamento, indicando que exerceu impacto sobre as variáveis contábeis que o compõem em todos os países estudados, assim como em seu conjunto.

$\mathrm{O}$ resultado encontrado a partir do Teste $\mathrm{t}$ já havia sido indicado quando foi feita a análise individual das variáveis componentes do índice, na qual se verificou que várias pesquisas alcançaram resultados similares quando encontraram evidências de impacto das IFRS sobre as variáveis contábeis. Ressalte-se os achados de Terzi, Oktem e Sen (2013) que relatam diferenças estatisticamente significativas nos índices das demonstrações contábeis com base em GAAP locais e em IFRS.

Na presença das IFRS, medidas como média, desvio padrão e mediana, para todos os países, seja em sua análise individual como eu seu conjunto, aumentaram (Ver Tabela 26). Dessa forma, mais uma vez, se tem atestado que a adoção das normas alterou o comportamento das variáveis contábeis nos países em estudo.

Pode-se dizer que a medida de desvio-padrão tem uma variação considerável, sem presença das IFRS varia de 8 até 22 e com a presença das IFRS varia de 9 até 17 (Ver Tabela 26). Assim, apesar de em ambas as situações haver um razoável afastamento dos dados, podese afirmar que, no período pós-IFRS, esse afastamento diminui, o que pode remeter ao fato de que a norma internacional vem atendendo ao caminho a que se propõe, no sentido de promover a harmonização entre os países.

Tabela 26 - Medidas descritivas por Dummy e países para os valores do Índice e sua comparação com o teste Ed t-Student

\begin{tabular}{|c|c|c|c|c|c|c|c|}
\hline \multirow{2}{*}{ País } & \multirow{2}{*}{ Dummy } & \multicolumn{5}{|c|}{ Medidas Descritivas } & \multirow{2}{*}{$\begin{array}{l}\text { t-Student } \\
\text { Valor-p }\end{array}$} \\
\hline & & Mínimo & Máximo & Média & DP & Mediana & \\
\hline \multirow[t]{2}{*}{ Austrália } & 0 & 0,0000 & 19,1100 & 10,5729 & 7,9197 & 13,4647 & \multirow[t]{2}{*}{0,005} \\
\hline & 1 & 17,4800 & 61,8300 & 34,1319 & 13,9192 & 35,7096 & \\
\hline \multirow[t]{2}{*}{ Alemanha } & 0 & 2,3000 & 47,3200 & 23,7363 & 13,3865 & 24,1077 & \multirow[t]{2}{*}{0,008} \\
\hline & 1 & 38,9700 & 72,9600 & 50,3994 & 15,9531 & 44,8337 & \\
\hline \multirow[t]{2}{*}{ Brasil } & 0 & 6,3500 & 28,5900 & 18,2858 & 9,1943 & 20,8814 & \multirow[t]{2}{*}{0,006} \\
\hline & 1 & 28,5900 & 81,4100 & 44,7863 & 16,4382 & 39,0177 & \\
\hline \multirow[t]{2}{*}{ China } & 0 & 6,4900 & 38,6100 & 23,3091 & 12,6587 & 23,3905 & \multirow[t]{2}{*}{0,021} \\
\hline & 1 & 26,8200 & 88,7400 & 48,0833 & 18,3480 & 44,4855 & \\
\hline \multirow[t]{2}{*}{ Canadá } & 0 & 11,3300 & 42,7500 & 26,8662 & 13,4032 & 20,9232 & \multirow[t]{2}{*}{0,020} \\
\hline & 1 & 32,8700 & 100,0000 & 54,0534 & 20,0406 & 50,0904 & \\
\hline
\end{tabular}


Tabela 26 - Medidas descritivas por Dummy e países para os valores do Índice e sua comparação com o teste Ed t-Student

\begin{tabular}{|c|c|c|c|c|c|c|c|}
\hline \multirow{3}{*}{ País } & \multirow{3}{*}{ Dummy } & & & & & & (Conclusão) \\
\hline & & \multicolumn{5}{|c|}{ Medidas Descritivas } & \multirow{2}{*}{$\begin{array}{c}\text { t-Student } \\
\text { Valor-p }\end{array}$} \\
\hline & & Mínimo & Máximo & Média & DP & Mediana & \\
\hline \multirow{2}{*}{$\begin{array}{l}\text { Reino } \\
\text { Unido }\end{array}$} & 0 & 3,7100 & 52,5700 & 25,5123 & 14,8850 & 25,7315 & \multirow[t]{2}{*}{0,013} \\
\hline & 1 & 42,0100 & 83,6000 & 54,7241 & 16,9928 & 49,1057 & \\
\hline \multirow[t]{2}{*}{ Itália } & 0 & 5,5700 & 54,4900 & 32,2699 & 15,7388 & 29,6187 & \multirow[t]{2}{*}{0,013} \\
\hline & 1 & 44,9200 & 87,9400 & 64,1505 & 21,8690 & 59,5919 & \\
\hline \multirow[t]{2}{*}{ França } & 0 & 2,7900 & 33,9900 & 18,5515 & 10,7161 & 19,3579 & \multirow[t]{2}{*}{0,001} \\
\hline & 1 & 29,7000 & 77,7100 & 47,8286 & 15,2533 & 42,6351 & \\
\hline \multirow{2}{*}{$\begin{array}{c}\text { Nova } \\
\text { Zelândia }\end{array}$} & 0 & 6,9500 & 34,1900 & 22,9392 & 12,6869 & 28,3607 & \multirow[t]{2}{*}{0,003} \\
\hline & 1 & 35,9800 & 94,0400 & 55,5993 & 16,8693 & 54,6553 & \\
\hline \multirow[t]{2}{*}{ Rússia } & 0 & 2,7500 & 33,8500 & 18,5157 & 10,7049 & 19,3200 & \multirow[t]{2}{*}{0,001} \\
\hline & 1 & 29,6400 & 77,7600 & 47,6630 & 15,2799 & 42,3121 & \\
\hline \multirow{2}{*}{$\begin{array}{c}\text { Áfica do } \\
\text { Sul }\end{array}$} & 0 & 6,5700 & 27,2100 & 17,5728 & 9,0971 & 15,5508 & \multirow[t]{2}{*}{0,027} \\
\hline & 1 & 22,6700 & 76,6200 & 38,7831 & 17,3173 & 34,4184 & \\
\hline \multirow[t]{2}{*}{ Todos } & 0 & 0,0000 & 59,4900 & 22,6911 & 13,1106 & 23,2030 & \multirow[t]{2}{*}{$<0,001$} \\
\hline & 1 & 17,4800 & 100,00 & 47,6881 & 17,5846 & 44,1552 & \\
\hline
\end{tabular}

$\mathrm{M}-\mathrm{W}=$ Teste $\mathrm{t}-$ Student.

Fonte: Dados da pesquisa, 2016.

Pode-se observar, no Gráfico 4 (seguindo a sequência de países da Tabela 26), que a presença das IFRS aumentou o valor do Índice contábil calculado, sendo provável que a introdução das IFRS trouxe mais influência para a participação das variáveis contábeis em estudo no patrimônio da firma, o que fez esse índice se mover para cima de forma tão perceptível.

Gráfico 4 - Comportamento dos países com Relação ao Índice Médio na Perspectiva de Ausência e de Presença das IFRS

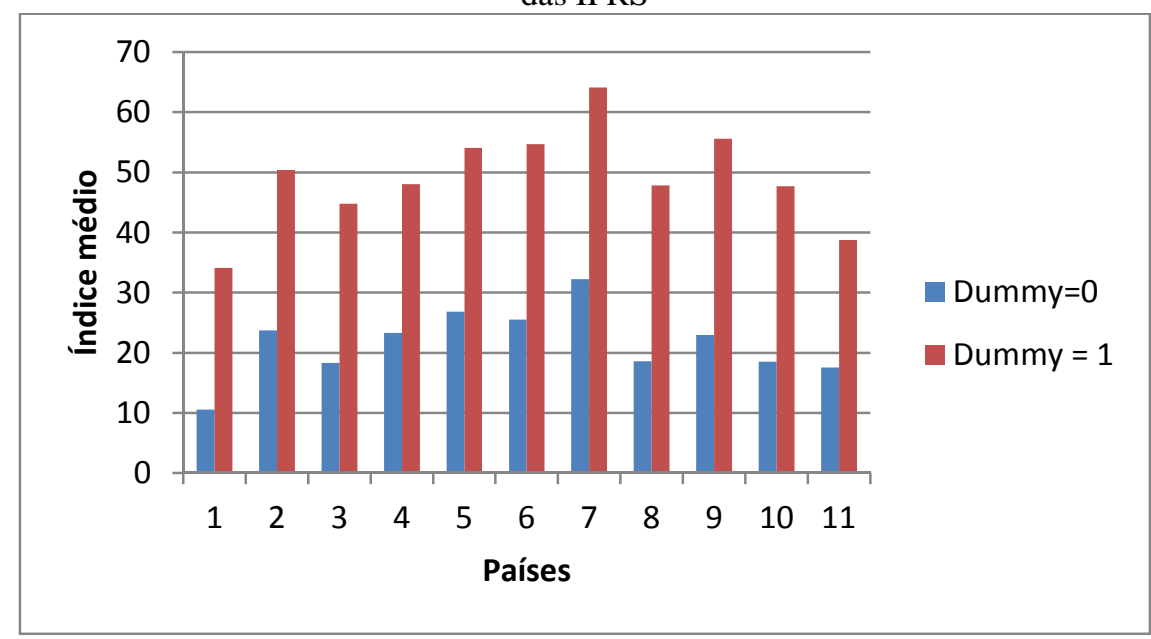

Fonte: Dados da pesquisa, 2016.

Assim, a estatística descritiva aqui explorada permite reforçar o contexto assumido na análise das variáveis contábeis componentes do índice encontrado na análise fatorial, ou seja, é estatisticamente comprovado que a presença das IFRS alterou o comportamento do índice em questão e foi no sentido de aumento. 
Desse modo, um modelo de Regressão logística binária foi aplicado, sendo utilizado como variável dependente a presença ou ausência das IFRS, e para variáveis independentes foram empregados o Índice, obtido via Análise Fatorial, e o Beta. Dois blocos (Bloco 0 e 1) são especificados para dar origem ao modelo de regressão logística. Para o bloco 0, somente a constante está incluída no modelo e as informações não são interessantes para a formação do modelo final de regressão logística (Ver Apêndice C-3 e C-4), portanto, é no bloco 1 que estão as informações sobre o modelo propriamente dito. $\mathrm{O}$ bloco 0 seria, então, o ponto de partida para se chegar ao bloco 1, depois cedendo lugar para o bloco 1.

Conforme o Apêndice C-1, pode-se observar que, das 165 observações em estudo, $93 \%$ delas foram aproveitadas para o cálculo da regressão logística, demonstrando que houve um alto percentual de aproveitamento.

O teste geral (omnibus test) - que avalia se os parâmetros deste modelo são todos nulos - é rejeitada com Valor-p < 0,001 (caso não fosse rejeitado, este modelo não poderia ser aplicado a estes dados).

Desta forma, ao se testar a capacidade preditiva do modelo, a Tabela 27 apresenta o resultado que testa a hipótese de que todos os coeficientes da equação logística são nulos. Assim, através da estatística de Wald se observa a significância estatística do modelo, constatando que, em apenas 1 passo, obteve-se o modelo final, onde se constata que os coeficientes são estatisticamente significativos, podendo concluir que pelo menos um dos coeficientes da regressão é diferente de zero. Os coeficientes, então, contribuem para melhorar a qualidade das predições do modelo, o que é positivo para o seu desenvolvimento.

Tabela 27 - Teste geral (omnibus test) de Significância - Modelo Chi-Square

\begin{tabular}{llccc}
\hline & & Chi-square & df & Sig. \\
\hline \multirow{3}{*}{ Passo 1 } & Passo & 98,256 & 2 & 0,000 \\
& Block & 98,256 & 2 & 0,000 \\
& Modelo & 98,256 & 2 & 0,000 \\
\hline
\end{tabular}

Fonte: Dados da pesquisa, 2016.

Conforme a Tabela 28, verifica-se que o teste da razão de verossimilhança apresentouse altamente significativo $(115,00)$ indicando que o modelo estimado pode ser útil para a análise em questão. Os valores do Pseudo R-Square são uma espécie de coeficiente de determinação $\left(\mathrm{R}^{2}\right)$, mas com uma interpretação mais complexa, entretanto, segue a regra básica: quanto maior, melhor é o ajuste do modelo. Dentre as três medidas apresentadas na Tabela 28, dá-se preferência à de Nagelkerke, visto ser uma medida no intervalo [0;1]. Nesse caso, a medida resultou 0,629 , considerando-se um bom ajuste do modelo. 
Tabela 28 - Sumário do Modelo

\begin{tabular}{lccc}
\hline Passo & -2 Log likelihood & Cox \& Snell R Square & Nagelkerke R Square \\
\hline 1 & $115,000^{\mathrm{a}}$ & 0,472 & 0,629 \\
\hline
\end{tabular}

Fonte: Dados da pesquisa, 2016.

O poder explicativo deste modelo foi determinado pelo $\mathrm{R}^{2}$ de Nagelkerke cujo valor foi 62,9\% (Ver Tabela 28), ou seja, aproximadamente 63\% da influência do índice e do Beta está relacionado com a adoção das IFRS.

O teste de Hosmer e Lemeshow confirmou a adequação deste modelo aos dados (valorP igual 0,777 (Ver Tabela 29)), pois, se as diferenças fossem significativas, o grau de acurácia do modelo não seria bom. Nesse caso, a ideia é aceitar a hipótese de que não existem diferenças significativas entre valores preditos e observados.

Tabela 29 - Teste Hosmer e Lemeshow

\begin{tabular}{|c|c|c|c|}
\hline Passo & Chi-square & $\mathrm{df}$ & Sig. \\
\hline 1 & 4,817 & 8 & 0,777 \\
\hline
\end{tabular}

Fonte: Dados da pesquisa, 2016.

A adequação do modelo foi ainda confirmada pela curva ROC (Receiver Operating Characteristic), apresentada na Figura 2.

Figura 2 - Curva ROC

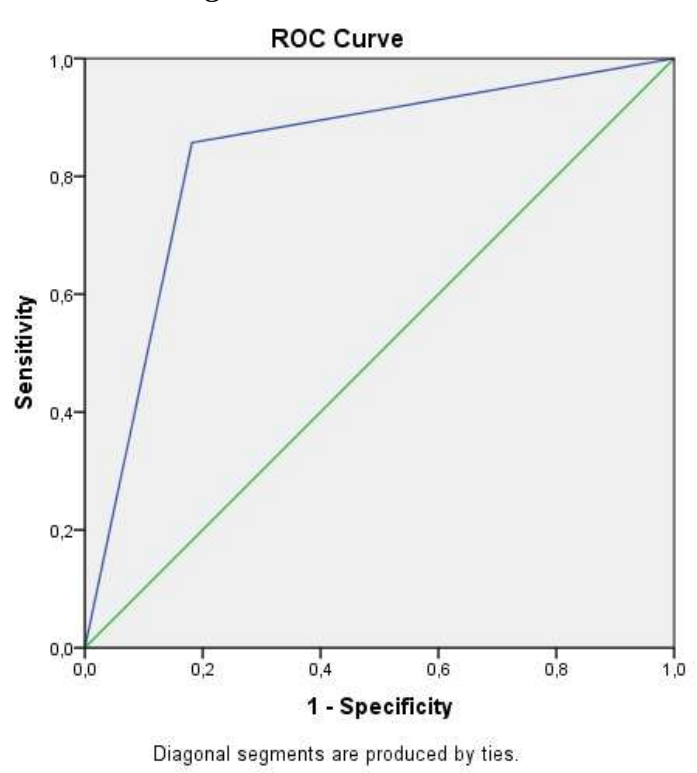

Fonte: Dados da pesquisa, 2016.

A Curva ROC é uma representação de sensibilidade (ou taxa de verdadeiros "sucessos") versus taxa de falsos "sucessos" (Ver Figura 2). Interpretando o sinal como os verdadeiros 
"sucessos" (sensibilidade) e o ruído, os falsos "sucessos" (1-especificidade). A Curva ROC descrimina entre dois estados, onde cada ponto da curva representa um compromisso diferente entre a sensibilidade e o falso "sucesso" que pode ser definido pela adoção de um diferente valor do ponto de corte de anormalidade. Assim, no resultado em questão, a curva ROC demonstrou boa sensibilidade na detecção dos casos de "sucesso" e baixa possibilidade de ocorrer taxas de falso "sucesso".

A área sob a curva ROC é uma medida do desempenho de um teste (índice de exatidão), assim, a sua qualidade para aceitação do modelo se baseia na área sobre o eixo horizontal e um Intervalo de confiança para esta área. Um teste totalmente incapaz de discriminar casos de sucesso e fracasso, teria uma área sob a curva de 0,5 (seria a hipótese nula). Acima de 0,70 é considerado desempenho satisfatório. O cálculo da área sob curva para o resultado em análise pode ser observado na (Tabela 30).

Tabela 30 - Área sob a Curva

\begin{tabular}{|c|c|c|c|c|}
\hline \multirow[t]{2}{*}{ Área } & \multirow[t]{2}{*}{ Erro padrão } & \multirow[t]{2}{*}{ Valor-p } & \multicolumn{2}{|c|}{ Intervalo a $95 \%$ de confiança } \\
\hline & & & Limite inferior & Limite superior \\
\hline 0,838 & 0,034 & $<0,001$ & 0,770 & 0,905 \\
\hline
\end{tabular}

Fonte: Dados da pesquisa, 2016.

De acordo com a Tabela 30, rejeita-se a hipótese de que a área sob a curva ROC é igual a 0,50 e os limites impostos pelo intervalo de confiança também ultrapassam esse valor, além de serem estatisticamente significantes. Isto significa adequação entre os valores IFRS previstos pelo modelo e os valores reais observados na pesquisa.

Como foi visto até aqui, todos os testes sugerem que, de forma geral, o modelo pode ser utilizado para estimar a probabilidade de uma observação se referir ao período pós-IFRS em função de um conjunto de variáveis independentes (Beta e Índice). Porém, ainda se faz necessário avaliar a significância de cada coeficiente em particular, uma vez que é indispensável verificar se cada um deles realmente pode ser utilizado como estimador de probabilidades. Para isso, foi realizada a estatística de Wald exposta na Tabela 31.

A Tabela 31 sugere que todas as variáveis podem ser aproveitadas na composição do modelo, já que seus coeficientes não são nulos e, dessa forma, pode-se afirmar que cada um deles exerce efeito sobre a probabilidade de a observação referir-se ao período pré-IFRS e pósIFRS 
Tabela 31 - Variáveis na Equação

\begin{tabular}{cccccccccc}
\hline & B & S.E. & Wald & df & Sig. & Exp(B) & \multicolumn{2}{c}{ 95\% C.I.for EXP(B) } \\
\cline { 7 - 10 } & & & & & & & & Inferior & Superior \\
\hline \multirow{2}{*}{${\text { Passo } 1^{\mathrm{a}}}^{\mathrm{a}}$} & BETA & $-2,696$ & 0,788 & 11,717 & 1 & 0,001 & 0,067 & 0,014 & 0,316 \\
& Índice & 0,158 & 0,025 & 38,661 & 1 & 0,000 & 1,171 & 1,114 & 1,230 \\
& Constante & $-2,700$ & 0,795 & 11,524 & 1 & 0,001 & 0,067 & & \\
\hline
\end{tabular}

Fonte: Dados da pesquisa, 2016.

Submetido a todos os testes, verifica-se que o modelo está estatisticamente apto a ser utilizado na solução do problema. Assim, é possível esboçar a regressão logística com boa margem de segurança, na Equação 26.

$$
\mathrm{Z}=-2,700-2,696 \text { BETA }+ \text { 0,158Índice }
$$

Com a equação logística, pode-se perceber que as variáveis Beta e o Índice alteram a probabilidade da observação referir-se ao período pós-IFRS de forma diferente. Enquanto que o Índice apresentou uma relação direta com a adoção das IFRS, o Beta apresentou relação inversa com a adoção das IFRS.

Porém, é importante destacar que o modelo logístico é expresso em termos de logaritmos da razão de chance. Assim, se houver a presença das IFRS de onde se extraiu o Beta, o efeito dessa característica sobre o logaritmo da razão de chance será da ordem de -2,696, tendo em vista que, em tal circunstância, essa variável é codificada com o número 1. De forma semelhante, pode-se afirmar que a existência da adoção das IFRS sofrerá uma variação de 0,158 para cada variação unitária que se verifique no Índice.

A Tabela 32 consegue melhor determinar a interpretação dos parâmetros.

Tabela 32 - Estimação dos parâmetros da regressão logística binária com variável dependente ausência ou presença da IFRS

\begin{tabular}{lccccc}
\hline \multicolumn{1}{c}{ Variáveis Independentes } & \multirow{2}{*}{ Parâmetros } & \multirow{2}{*}{ Valor-p } & \multirow{2}{*}{ Odds Ratio } & \multicolumn{2}{c}{ IC a 95\% } \\
\cline { 5 - 6 } & & & & Inferior & Superior \\
\hline BETA & $-2,696$ & 0,001 & 0,067 & 0,014 & 0,316 \\
Índice & 0,158 & 0,000 & 1,171 & 1,114 & 1,230 \\
Constant & $-2,700$ & 0,001 & 0,067 & & \\
\hline Fontenyyyyy
\end{tabular}

Fonte: Dados da pesquisa, 2016.

Portanto, há 1,17 vezes mais chance de se ter a presença da norma com um índice maior (Ver Odds Ratio do Índice na Tabela 32) e 14,9 (= 1/0,067) vezes mais chance de uma redução do Beta estar relacionado com a presença das IFRS (Ver Odds Ratio do Beta na Tabela 32). A 
capacidade preditiva deste modelo é de 83,8\% (Ver Apêndice C-6), embora este modelo não tenha a finalidade preditiva de acordo com a característica deste problema. Portanto, é mais provável o efeito da implantação da norma em valores altos do índice e valores baixos do Beta.

A ideia de aumento do índice quando na presença das IFRS, pode-se dizer que corrobora os achados de Terzi, Oktem e Sen (2013), que identificaram aumento nos valores contábeis, como índices de liquidez, retorno sobre ativos, retorno sobre o patrimônio, índices da dívida, volume de capital próprio, bens tangíveis e patrimônio líquido, no pós-IFRS.

Deve-se dar destaque à similaridade com o resultado encontrado por Papadamou e Tzivinikos (2013), os quais verificaram que a introdução das IFRS reforçou a capacidade explicativa dos dados contábeis, de forma que a relevância de índices contábeis, medidas de liquidez, credibilidade, lucro por ação e as provisões para perdas de crédito foram inversamente proporcionais ao risco após a adoção das IFRS. Portanto, com a adoção das IFRS, a relevância dos dados contábeis aumentaram e o risco diminuiu.

Esse resultado é algo de se esperar diante da proposta do IASB quando da criação de normas contábeis internacionais, pois o objetivo sempre foi aumentar a qualidade da informação contábil e o aumento do conteúdo informacional das variáveis contábeis na presença das IFRS demonstram isso. Papadamou e Tzivinikos (2013) destacam que o aumento do conteúdo de informação das variáveis contábeis (empréstimos, liquidez, credibilidade, ganhos e diversificação) pode ser facilmente ligado à adoção das IFRS, promovido a partir da harmonização da Contabilidade.

Portanto, o conteúdo das variáveis contábeis estudadas pode ser positivamente relacionado à presença das IFRS, enquanto que o Beta pode ser negativamente associado.

A associação entre Beta e o Índice pode ser avaliada de forma concisa pelo teste QuiQuadrado para uma categorização destas variáveis segundo os quartis "1" e "3”, dividindo-as em três categorias: Baixo, Médio e Alto valor. Na amostra em estudo os Betas se apresentaram em maior número em torno da categoria média (Ver Tabela 33).

Tabela 33 - Classificação do Índice e do Beta por Tabulação Cruzada

\begin{tabular}{|c|c|c|c|c|c|c|}
\hline \multirow{8}{*}{ 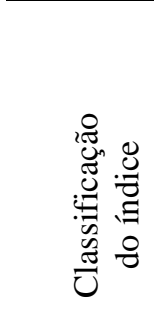 } & \multirow{4}{*}{ Baixo } & \multirow{4}{*}{$\begin{array}{l}\text { Contagem } \\
\% \text { do Total }\end{array}$} & \multicolumn{3}{|c|}{ Classificação do Beta } & \multirow{2}{*}{ Total } \\
\hline & & & Beta Baixo & Beta Médio & Beta Alto & \\
\hline & & & 21 & 17 & 9 & 47 \\
\hline & & & $13,6 \%$ & $11,0 \%$ & $5,8 \%$ & $30,5 \%$ \\
\hline & Médi & Contagem & 18 & 57 & 23 & 98 \\
\hline & Medio & $\%$ do Total & $11,7 \%$ & $37,0 \%$ & $14,9 \%$ & $63,6 \%$ \\
\hline & & Contagem & 1 & 4 & 4 & 9 \\
\hline & Alto & $\%$ do Total & $0,6 \%$ & $2,6 \%$ & $2,6 \%$ & $5,8 \%$ \\
\hline \multirow{2}{*}{ Total } & & Contagem & 40 & 78 & 36 & 154 \\
\hline & & $\%$ do Total & $26,0 \%$ & $50,6 \%$ & $23,4 \%$ & $100,0 \%$ \\
\hline
\end{tabular}

Fonte: Dados da pesquisa, 2016. 
$\mathrm{O}$ valor $\mathrm{p}$ deste teste foi 0,006 , mostrando que há associação significativa entre as variáveis Beta e o Índice. 


\section{CONSIDERAÇÕES FINAIS}

O objetivo deste trabalho foi analisar a influência da adoção das IFRS no risco sistêmico. Para isso utilizou-se uma amostra de 11 países, possuindo diferenças na formação do seu modelo contábil, sendo eles: Austrália; Alemanha; Brasil; China; Canadá; Reino Unido; Itália; França; Nova Zelândia; Rússia e África do Sul. Considerou-se, para tanto, o risco sistêmico captado pelo Beta de Mercado, estimado com base nos índices de mercado dos países em estudo.

Os resultados encontrados neste estudo confirmaram a tese que a adoção da IFRS impacta no risco sistêmico. No entanto, esperava-se que a adoção das IFRS, ao aumentar a qualidade da informação contábil, ocasionasse uma diminuição do risco, no entanto, os achados evidenciaram que as alterações no Pós-IFRS afetaram o risco de maneiras diferentes, visto que, em alguns casos, o risco tenha diminuído, enquanto em outros, houve o aumento. Independente da direção, se encontrou diferenças estatisticamente significante na maior parte dos casos, o que confirma que o impacto existiu.

Tais achados são consistentes com os argumentos formulados no sentido de que as IFRS influenciam o ambiente econômico, alterando inclusive as expectativas do mercado, uma vez que altera a informação contábil e, essa por sua vez, influencia as reações dos investidores.

No entanto, é válido salientar que apenas adoção das IFRS não é condição suficiente para influenciar o risco sistêmico. Dessa forma, ao analisar se o risco estaria sendo influenciado pela Taxa de câmbio e Taxa de juros, associados à adoção das IFRS, não se identificou mudanças expressivas no resultado inicialmente encontrado, confirmando a tese de que o risco tem associação com a mudança na normatização.

Papadamou e Tzivinikos (2013) também levantaram esse mesmo aspecto, porém especificamente para os bancos, de forma que os resultados empíricos revelam que todos os bancos estão expostos ao risco de mercado, enquanto a taxa de juro e risco de taxa de câmbio os afetam apenas ocasionalmente.

Em análise individual dos países, a adoção das IFRS provocou aumento no risco sistêmico, sendo observado ainda, em alguns países, a redução no risco sistêmico e, embora em uma quantidade de países menos expressiva, impacto nulo, o que pode ser explicado pelo fato de que o modelo contábil no Pré-IFRS já poderia ter englobado características encontradas no novo padrão contábil, assim como para alguns países, o processo de adoção ainda está recente e isso pode estar influenciando as expectativas dos usuários quanto às reais consequências advindas da adoção. 
A realização de estatísticas descritivas e correlação entre os países permitiram observar que as respostas do risco nos diferentes países à adoção das IFRS não são padronizadas, pois aspectos culturais e econômicos fazem parte dessa relação.

Com relação ao estudo do comportamento do risco nos períodos de pré e pós-IFRS no conjunto dos países, pode-se confirmar que houve redução do Beta (Pós-IFRS), existindo um possível indicativo de diminuição do risco, se podendo estabelecer um alinhamento com a teoria e os órgãos normatizadores, os quais defendem que as IFRS aumentam a qualidade da informação contábil. No entanto, é imprescindível acrescentar que, como essa análise refere-se a países com características peculiares, que inclusive começaram a participar do processo de convergência em períodos diferentes, impossibilita apontar um padrão de comportamento para o risco.

Complementando a busca por verificar se a adoção das IFRS influencia o risco, ao testar o efeito das Variáveis Contábeis e o Beta nesse contexto, se verificou um aumento do conteúdo informacional da Contabilidade, permitindo inferir uma diminuição no risco. Portanto, se confirma o que foi discutido na teoria em relação à inserção dos países no processo de convergência internacional das práticas contábeis, no sentido de que a adoção das IFRS aumenta a qualidade da informação contábil, através do aumento no conteúdo informacional, diminuindo o risco.

Essa tese teve como escopo maior a introdução do Beta como uma variável capaz de captar, indiretamente, a qualidade da informação contábil, integrando o rol das proxies destinadas a analisá-la. Isso porque, a partir dos pressupostos levantados, o risco sistêmico seria afetado pela qualidade das informações contábeis. Dessa forma, ao se estudar um cenário com introdução de novo padrão contábil, a redução no risco sistêmico, seria, ceteris paribus, ocasionada pelo aumento da qualidade das informações contábeis.

No geral, uma das principais implicações dos resultados aqui alcançados é que os sistemas contábeis estão transitando para o fornecimento de informações mais transparentes com uma maior capacidade informacional das variáveis contábeis, no entanto, os resultados aqui encontrados, seguem os achados da pesquisa de Braga (2016), quando concluiu que a adoção obrigatória das IFRS, se não acompanhada por reformas no ambiente econômico e institucional, não pode proporcionar o alcance dos benefícios esperados.

O processo de inserção de novas normas contábeis traz consequências, tanto social como econômica, aprimorando as informações disponíveis aos investidores e credores, de forma que passam a transformar suas decisões econômicas, melhorando a alocação de recursos. Essa vertente já tem sido reconhecida pelas firmas, de forma que, elas têm se preocupado com o 
processo de elaboração das normas, buscando a adoção de estratégias de lobbying em relação à regulamentação contábil de seu interesse (SANTOS; SANTOS, 2014). Portanto, existe um conjunto de interesses que se tornam responsáveis pela qualidade da informação contábil e sua constante melhoria para o usuário da informação contábil.

Este estudo contribui com a literatura relacionadas aos seguintes temas: efeitos econômicos e informacionais na adoção das IFRS; comprovar empiricamente que a mudança de padrão contábil por si só, não é capaz de aumentar a qualidade da informação contábil; introdução da variável risco sistêmico como atributo para a qualidade da informação contábil.

Nesse sentido, destacam-se, como principais limitações: (1) A abrangência da variável risco sistêmico, posto que ela foi limitada ao Beta (risco de mercado) estimado, considerando que se trabalhou aqui um conceito diferenciado da definição tradicional do Beta individual trabalhado na teoria de finanças; (2) A não coincidência de períodos de inserção dos países no processo de convergência. É importante destacar que, apesar das limitações relatadas, o estudo permanece válido, pois os objetivos esperados foram alcançados.

Em comunhão com as limitações aqui destacadas, novas pesquisas são sugeridas, no sentido de trabalhar melhor tais limitações e ainda conseguir estabelecer outras respostas para o tema em estudo, tais como:

$\checkmark$ Aplicar a metodologia aqui estudada em outros países;

$\checkmark$ Estudar de forma específica alguns setores que são mais afetados por determinadas normas propostas pelo IASB;

$\checkmark$ Estudar as variáveis contábeis a partir de causa e efeio;

$\checkmark$ Estudar aspectos culturais e/ou econômicos que possam ter ocasionados alguns dos resultados aqui encontrados.

Assim, essa pesquisa não teve a intenção de esgotar o tema em estudo, mas de proporcionar aos usuários da informação contábil um feedback a respeito da inserção dos países no processo de convergência, estabelecendo uma nova ótica para análise do tema, que é a variável econômica de risco. E, por fim, intencionou-se trazer insights para os órgãos reguladores no sentido da abrangência que têm as normas elaboradas por eles, confirmando se os seus objetivos têm sido concretizados, realizando acompanhamento e trabalhando com a possibilidade de se lograr melhorias contínuas. 


\section{REFERÊNCIAS}

ABDELGHANY, K. E. Disclosure of market risk or accounting measures of risk: na empirical study, Managerial Auditing Journal, V. 20, I. 8, p. 867-875, 2005.

AGRESTI, A. An Introduction to Categorical Data Analysis. 2 ed. John Wiley \& Sons, Inc., New Jersey, 2007.

AKERLOF, G. A. The Market for "Lemons": Quality Uncertainty and the Market Mechanism. The Quarterly Journal of Economics, V. 84, N. 3. p. 488-500, 1970.

ALBU, N. et al. A story about IAS/IFRS implementation in Romania: An institutional and structuration theory perspective. Journal of Accounting in Emerging Economies, V. 1, N. 1, p. 76-100, 2011.

AL-OMARI, A. The Institutional Framework of Financial Reporting in Jordan. European Journal of Economics, Finance and Administrative Sciences, N. 22, p. 32-50, 2010.

AMES, D. IFRS adoption and accounting quality: The case of South Africa. Journal of Applied Economics and Business Research-JAEBR, V. 3, N. 3, p. 154- 165, 2013.

AMORIM, A. L. G. C.; LIMA, I. S.; MURCIA, F. D. Análise da Relação entre as Informações Contábeis e o Risco Sistemático no Mercado Brasileiro. Revista Contabilidade \& Finanças - USP, V. 23, N. 60, p. 199-211, 2012.

AMORIM, A. L. G. C.; LIMA, I. S.; PIMENTA JÚNIOR, T. Informação Contábil e Beta de Mercado. Revista Universo Contábil, V. 10, N. 4, p. 128-143, out./dez., 2014.

ARGENTO, D. Kees Camfferman \& Stephen A. Zeff, Financial reporting and global capital markets. A history of the International Accounting Standards Committee, 1973-2000. Journal of Management \& Governance, Reviews and Overviews, V. 12, N. 1, p. 127-132, 2008.

ARMSTRONG, C. S. et al. Market Reaction to the Adoption of IFRS in Europe. The Accounting Review, V. 85, N. 1, p. 31-61, 2010.

AUBERT, F. GRUDNITSKI, G. The Impact and Importance of Mandatory Adoption of International Financial Reporting Standards in Europe. Journal of International Financial Management and Accounting, V. 22, N. 1, p. 1-26, 2011.

BAGINSKI, S. P. WAHLEN, J. M. Residual Income Risk, Intrinsic Values, and Share Prices, The Accounting Review, V. 78, N. 1, p. 327-351, Jan. 2003.

BALL, R. International Financial Reporting Standards (IFRS): pros and cons for investors. Accounting and Business Research, Internacional Accounting Policy Forum, 36 (Número Especial), p. 5-27, 2006.

BALL, R.; BROWN, P. An empirical evaluation of accounting income numbers. Journal of Accounting Research, V. 6, N. 2, p.159-178, 1968. 
BARBERIS, N.; THALER, R. H., A Survey of Behavioral Finance. 2002. Disponível em: < http://papers.ssrn.com/sol3/papers.cfm?abstract_id=327880>. Acesso em: 30 Jul. 2014.

BARBU, E.; BAKER, R. Institutions involved in international convergence of accounting standards: a neo-institutional and historical analysis. 2010. Disponível em:

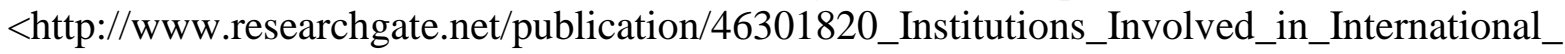
Convergence_of_Accounting_Standards_A_Neo-Institutional_and_Historical_Analysis $>$. Acesso em: 30 de Jul de 2014.

BARTH, M. E. et al. Accounting Quality: International Accounting Standards and US GAAP. 2006. Disponível em: <http://public.kenan-flagler.unc.edu/faculty/langm/bllw_0302.pdf>. Acesso em: 30 de Jul de 2014.

BARTH, M. E. Global Financial Reporting: Implications for U.S. Academics. The Accounting Review, V. 83, N. 5, p. 1159-1179, 2008.

BARTH, M. E.; BEAVER, W. H.; LANDSMAN, W. R. The Relevance of the Value Relevance Literature For Financial Accounting Standard Setting: Another View. Journal of Accounting and Economics. V. 31, N. 1-3, p. 77-104, Sep. 2001.

BARTH, M. E.; LANDSMAN, W. R.; LANG, M. H. International Accounting Standards and Accounting Quality. Journal of Accounting Research, V. 46. N. 3. p. 467-498, 2008.

BARTOV, E.; GOLDBERG, S. R; KIM, M. Comparative Value Relevance Among German, U.S., and International Accounting Standards: A German Stock Market Perspective. Journal of Accounting, Auditing \& Finance. V. 20, N. 2, p. 95-119, Apr. 2005.

BASU, S. The conservatism principle and the asymmetric timeliness of earnings. Journal of Accounting and Economics. V. 24, N. 1, p. 3-37, 1997.

BEAVER, W. H. The Information Content of Annual Earnings Announcements. Journal of Accounting Research, Empirical Research in Accounting: Selected Studies, V. 6, p. 67-92, 1968.

BEAVER, W. H.; KETTLER P.; SCHOLES, M. The Association between Market Determined and Accounting Determined Risk Measures. The Accounting Review. V. 45, N. 4, p. 654-682, Out., 1970.

BEAVER, W. H.; LAMBERT R.; MORSE, D. The Information Content of Security Prices. Journal of Accounting and Economics, V. 2, N. 1, p. 3-28, 1980.

BEAVER, W. H.; LAMBERT, R. A.; RYAN, S. G. The Information Content of Security Prices a Second Look. Journal of Accounting and Economics, V. 9, N. 2, p. 139-157, 1987.

BEAVER, W. H.; MANEGOLD, J. The Association Between Market-Determined and Accounting-Determined Measures of Systematic Risk: Some Further Evidence. The Journal of Financial and Quantitative Analysis, V. 10, N. 2, p. 231-284, Jun., 1975.

BERNOULLI, D. Exposition of a New Theory on the Measurement of Risk. Econometrica: Journal of The Econometric Society, V. 22, N. 1, p. 23-36, 1954. 
BERNSTEIN, P. L. Desafio aos Deuses: A fascinante história do risco. 16 ed. Rio de Janeiro: Campus, 1997.

BEZERRA, F. A. Análise Fatorial. In: Corrar, L. J.; Paulo, E.; Dias Filho, J. M. (Coord.). Análise Multivariada: para os cursos de administração, ciências contábeis e economia. São Paulo: Atlas, 2009.

BOLLERSLEV, T.; ENGLE, R. F.; WOOLDRIDGE, J. M. A capital asset pricing model with timevarying covariances. The Journal of Political Economy, V. 96, N. 1, p. 116-131, 1988.

BORKER, D. R. Stepped-Up Progress On IFRS In Russia: History In The Making. International Business \& Economics Research Journal, V. 11, N. 2, p. 255-268, Feb., 2012.

BOTOSAN, C. A. Disclosure level and the cost of equity capital. The Accounting Review, V. 72, N. 3, p. 323-349, 1997.

BOUMEDIENE, E.; BOUMEDIENE, S. L.; NAFTI, O. Impact Of Adopting IAS-IFRS On The Handling Of Accounting Data: The Case Of France. Journal of Applied Business Research, V. 30, N.4, p. 1239-1252, Jul/Aug, 2014.

BOWMAN, R. G. The Theoretical Relationship Between Systematic Risk and Financial (Accounting) Variables. The Journal of Finance, V. 34, N. 3, p. 617-630, Jun., 1979.

BRADFIELD, D. Investment Basics XLVI. On estimating the beta coeficiente. Investment Analysts Journal, N. 57, 2003.

BRAGA, J. P. Efeitos da adoção obrigatória das IFRS sobre a qualidade do ambiente informacional: a relevância dos fatores institucionais. 164p. Tese (Doutorado em Ciências Contábeis) - Programa de Pós-Graduação em Contabilidade - Universidade de São Paulo/USP. São Paulo, 2016.

BRIMBLE, M.; HODGSON, A. Assessing the risk relevance of accounting variables in diverse economic conditions, Managerial Finance, V. 33 I. 8, p. 553-573, 2007.

BROCHET, F.; JAGOLINZER, A. D.; RIEDL, E. J. Mandatory IFRS Adoption and Financial Statement Comparability. Contemporary Accounting Research. V. 30, N. 4, p. 1373-1400, 2013.

BROWN, P.; KENNELLY, J. W. The informational content of quarterly earnings: an extension and some further evidence. The Journal of Business, V. 45, N. 3, p. 403-415, 1972.

BRUGGEMANN, U.; HITZ, J-M; SELLHORN, T. Intended and unintended consequences of mandatory IFRS adoption: A review of extant evidence and suggestions for future research. European Accounting Review, V. 22, N. 1, p. 1-37, 2013.

BUCHINSKY, M. Recent Advances in Quantile Regression Models: A Practical Guideline for Empirical Research. The Journal of Human Resources, V. 33, N. 1, p. 88-126, 1998. 
CALLAO, S.; JARNE; J. I.; LAÍNEZ, J. A. Adoption of IFRS in Spain: Effect on the comparability and relevance of financial reporting. Journal of International Accounting, Auditing and Taxation, V. 16, N. 2, p. 148-178, 2007.

CALlEGARI-JACQUES, S. M. Bioestatística: Princípios e Aplicações. Porto Alegre: Artmed, 2003.

CAMFFERMAN, K.; ZEFF, S. A. Financial reporting and global capital markets: A history of the International Accounting Standards Committee, 1973-2000. Oxford University Press, 2007.

CAPELLETTO, L. R. Mensuração do risco sistêmico no setor bancário com utilização de variáveis contábeis e econômicas. 259 p. Tese (Doutorado em Ciências Contábeis) Programa de Pós-Graduação em Contabilidade - Universidade de São Paulo/USP. São Paulo, 2006.

CAPPIELLO, L.; FEARNLEY, T. A. International CAPM with Regime Switching Parameters: Executive Summary. Jul., 2000. Disponível em<http://www.swissfinanceinstitute.ch/rp17.pdf>. Acesso em: Jan. 2016.

CHALMERS, K.; CLINCH, G. GODFREY, J. M. Changes in value relevance of accounting information upon IFRS adoption: Evidence from Australia. Australian Journal of Management, V. 36, V. 2, p. 151-173, 2011.

CHIHA, H. TRABELSI, N. S. HAMZA, S. E. The Effect of IFRS on Earnings Quality in a European Stock Market: Evidence from France. Interdisciplinary Journal of Research in Business, V. 2, I. 12, p. 35-47, 2013.

CHUN, L. S.; RAMASAMY, M. Accounting variables as determinants of systematic risk in Malaysian common stocks. Asia Pacific Journal of Management, V. 6, I. 2, p 339-350, Apri., 1989.

COHEN, L.; MALLOY, C; POMORSKI, L. Decoding Inside Information. The Journal of Finance. V. 67, N. 3, p. 1009-1043, 2012.

COLLINS, D. W. et al. Lack of timeliness and noise as explanations for the low contemporaneous return-earnings association. Journal of Accounting and Economics. V. 18, p. 289-324, 1994.

CORMIER, D.; DEMARIA, S.; LAPOINTE-ANTUNES, P. La valorisation boursière des états financiers des sociétés françaises: pertinence du référentiel IFRS. Comptabilité Contrôle-Audit. V. 18, n. 2, P. 99-124, 2012.

COSTELLO, A. B.; OSBORNE, J. W. Best Practices in Exploratory Factor Analysis: Four Recommendations for Getting the Most From Your Analysis. Practical Assessment Research \& Evaluation, V. 10, N. 7, Jul., 2005.

DASKE, H. et al. Mandatory IFRS Reporting Around the World: Early Evidence on the Economic Consequences. Journal of Accounting Research, V. 46, N. 5, p. 1085-1142, 2008. 
DECHOW, P. M.; GE, W.; SCHRAND, C. Understanding earnings quality: A review of the proxies, their determinants and their consequences. Journal of Accounting and Economics, V. 50, N. 2-3, p. 344-401, 2010.

DECHOW, P. M.; KOTHARI, S. P.; WATTS, R. L. The Relation Between Earnings and Cash Flows. Journal of Accounting and Economics, V. 25, N. 2, p. 133-168, 1998.

DEFOND, M.; HUNG, M.; TREZEVANT, R. Investor protection and the information content of annual earnings announcements: International evidence. Journal of Accounting and Economics, V. 43, N. 1, p. 37-67, Mar. 2007.

DIAS FILHO, J. M.; CORRAR, L. J. Regressão Logística. In: Corrar, L. J.; Paulo, E.; Dias Filho, J.M. (Coord.). Análise Multivariada: para os cursos de administração, ciências contábeis e economia. São Paulo: Atlas, 2009.

DILLARD, J. F.; RIGSBY, J. T.; GOODMAN, C. The making and remaking of organization context: Duality and the institutionalization process. Accounting, Auditing \& Accountability Journal, V. 17, N. 4, p. 506 - 542, 2004.

DIMAGGIO, P. J.; POWELL, W. W. The Iron Cage Revisited: Institutional Isomorphism and Collective Rationality in Organizational Fields. American Sociological Review, V. 48, N. 2, p. 147-160, 1983.

DIMITROPOULOS, P. E.; et al. The impact of IFRS on accounting quality: Evidence from Greece. Advances in Accounting, incorporating Advances in International Accounting, V. 29, N. 1, p. 108-123, Jun. 2013.

EASLEY, D.; HVIDKJAER, S.; O'HARA, M. Is Information Risk a Determinant of Asset Returns? The Journal of Finance, V. 57, N. 5, p. 2185-2221, 2002.

EBIMOBOWEI, A. Convergence of Accounting Standards: The Continuing Debate. Asian Journal of Business Management, V. 4, N. 2, p. 159-165, 2012.

ELSHANDIDY, T. Value relevance of accounting information: Evidence from an emerging Market. Advances in Accounting, V. 30, N. 1, p. 176-186, Jun, 2014.

ELTON, E. J. et al.. Moderna Teoria de Carteiras e Análise de Investimentos. Trad. Antonio Zoratto Sanvincente. São Paulo: Atlas, 2004.

ELYASIANI, E.; MANSUR, I. The Association Between Market and Exchange Rate Risks and Accounting Variables: A GARCH Model of the Japanese Banking Institutions, Review of Quantitative Finance and Accounting, V. 25, p. 183-206, 2005.

ENGLE, R. F. Autoregressive conditional heteroscedasticity with estimates of the variance of united kingdom inflation. Econometrica: Journal of the Econometric Society, V. 50. N. 4, p. 987-1007, Jul., 1982.

ENGLE, R. F.; BOLLERSLEV, T. Modelling the persistence of conditional variances. Econometric reviews, V. 5, N. 1, p. 1-50, 1986. 
ENGLE, R. F.; KRONER, K. F. Multivariate simultaneous generalized arch. Econometric theory, V. 11, N. 1, p. 122-150, 1995.

FAMA, E. F. Efficient capital markets: a review of theory and empirical work. The Journal of Finance. V. 25, N. 2, p. 383-417, 1970.

FAMA, E. F. Efficient Capital Markets: II. The Journal of Finance, V. 46, N. 5, p. 1575$1617,1991$.

FAMA, E. F.; FRENCH, K. R. O Modelo de Precificação de Ativos de Capital: Teoria e Evidências. Revista de Administração de Empresas - RAE, V. 47, N. 2, ABR./JUN. 2007.

FASB. Financial Accounting Standards Board. International Convergence of Accounting Standards: A Brief History. Disponível em:

<http://www.fasb.org/jsp/FASB/Page/SectionPage\&cid=1176156304264>. Acesso em 30 Jul. 2014a.

FASB. Financial Accounting Standards Board. International Convergence of Accounting Standards: Overview. Disponível em: < http://www.fasb.org/jsp/FASB/Page/SectionPage\&cid=1176156306962>. Acesso em $30 \mathrm{Jul.}$ 2014b.

FERNANDES, F. C.; SOUZA, J. A. L.; FARIA, A. C. Evidenciação de riscos e captação de recursos no mercado de capitais: um estudo do setor de energia elétrica. Contabilidade, Gestão e Governança, V. 13, N. 1, p. 59-73, 2010.

FRANKEL, R.; LI, X. Characteristics of a firm's information environment and the information asymmetry between insiders and outsiders. Journal of Accounting and Economics, V 37, N. 2, p. 229-259, 2004.

FRIEDMAN, M.; SAVAGE, L. J. The Utility Analysis of Choices Involving Risk. The Journal of Political Economy, V. 56, N. 4, p. 279-304, 1948.

GARROD, N.; MRAMOR, D. On Accounting Flows and Systematic Risk, Southern African Business Review, V. 8, N. 1, p. 1-6, May, 2004.

GASTÓN, S C. et al. IFRS adoption in Spain and the United Kingdom: Effects on accounting numbers and relevance. Advances in Accounting. V. 26, I. 2, p. 304-313, Dec., 2010.

GENERALOVA, N.; SOKOLOVA, N. IFRS in Russia: History, Realities and Consequences, GV - Global Virtual Conference, V. 2, I. 1, Apr., 2014.

GLAUM, M. et al., M. Introduction of international accounting standards, disclosure quality and accuracy of analysts' earnings forecasts. European Accounting Review, V. 22, N. 1, p. 79116, 2013.

GODEIRO, L. L. CAPM Internacional, Betas Dinâmicos e Otimização de Portfólios: O país com maior risco é o mais rentável? 2015. Disponível em:

<https://www.researchgate.net/publication/282785566_CAPM_Internacional_Betas_Dinamic 
os_e_Otimizacao_de_Portfolios_O_pais_com_maior_risco_e_o_mais_rentavel>.Acesso em: Jan. 2016.

GODEIRO, L. L. Testando o CAPM no mercado acionário brasileiro utilizando GARCH Multivariado entre 1995 e 2012. 2012. 60 p. Dissertação (Mestrado em Economia Política) Pontífica Universidade Católica de São Paulo - PUC-SP, São Paulo, 2012.

GONEDES, N. J. A Note on Accounting-Based and Market-Based Estimates of Systematic Risk. The Journal of Financial and Quantitative Analysis, V. 10, N. 2, p. 355-365, Jun, 1975.

GONEDES, N. J. Evidence on the Information Content of Accounting Numbers: AccountingBased and Market-Based Estimates of Systematic Risk. The Journal of Financial and Quantitative Analysis, V. 8, N. 3, p. 407-443, Jun, 1973.

GRECCO, M. C. P. O Efeito da convergência brasileira às IFRS no gerenciamento de resultados das empresas abertas brasileiras não financeiras. BBR-Brazilian Business Review, V. 10, N. 4, p. 117-140, 2013.

GUJARATI, D. N.; PORTER, D. C. Econometria Básica. Trad. Denise Durante, Mônica Rosemberg, Maria Lúcia G. L. Rosa. 5 ed. Porto Alegre: Bookman, 2011.

HAIR JÚNIOR, J. F. et al. Análise Multivariada de Dados. Trad. Adonai Schlup Sant'Ana. 6 ed. Porto Alegre: Bookman, 2009.

HAMADA, R. S. The Effect of the Firm's Capital Structure on the Systematic Risk of Common Stocks. The Journal of Finance, V. 27, N. 2, p. 435-452, May, 1972.

HASSAN, O. A. G. et al. Voluntary disclosure and risk in an emerging market, Journal of Accounting in Emerging Economies, V. 1, I. 1, p. 33-52, 2011.

HEALY, P. M.; PALEPU, K. G. Information asymmetry, corporate disclosure, and the capital markets: A review of the empirical disclosure literature. Journal of Accounting and Economics. 31, N1-3, p. 405-440, 2001.

HILL, N. C. STONE, B. K. Accounting Betas, Systematic Operating Risk, and Financial Leverage: A Risk-Composition Approach to the Determinants of Systematic Risk. The Journal of Financial and Quantitative Analysis, V. 15, N. 3, p. 595-637, Sep., 1980.

HILLSON, D. The Risk Breakdown Structure (RBS) as an Aid to effective Risk Management. Presented at the fifth European Project Management Conference, PMI Europe 2002, Cannes France, 2002.

HOLTHAUSEN, R. W.; WATTS, R. L. The relevance of the value-relevance literature for financial accounting standard setting. Journal of Accounting and Economics, V. 31, N. 1-3, p. 3-75, Sep, 2001.

HOPE, O. Disclosure Practices, Enforcement of Accounting Standards and Analyts' Forecast Accuracy: An International Study. 2002. Disponível em: < http://papers.ssrn.com/sol3/papers.cfm?abstract_id=353160>. Acesso em: 30 Jul. 2014. 
HOUQE, M. N.; EASTON, S.; VAN ZIJL, T. Does mandatory IFRS adoption improve information quality in low investor protection countries? Journal of International Accounting, Auditing and Taxation, V. 23, N. 2, p. 87-97, 2014.

HUNG, M.; SUBRAMANYAM, K. R. Financial Statement Effects of Adopting International Accounting Standards: the Case of Germany. Review of Accounting Studies, V. 12, I. 4, p. 623-657, Dec., 2007.

IASPLUS. About the IASB. Disponível em: <http://www.iasplus.com/en/resources/ifrsf/iasbifrs-ic/iasb>. Acesso em: 30 Jul. 2014 b.

IASPLUS. About the International Accounting Standards Committee (IASC). Disponível em: <http://www.iasplus.com/en/resources/ifrsf/history/resource25>. Acesso em: 30 Jul. 2014a.

IASPLUS. IFRS FOUNDATION. Disponível em:

<http://www.iasplus.com/en/resources/ifrsf/governance/ifrsf >. Acesso em: 30 Jul. 2014c.

IATRIDIS, G. IFRS Adoption and Financial Statement Effects: The UK Case. International Research Journal of Finance and Economics, N. 38, p. 165-172, 2010.

IFRS. 2011. Africa Embraces IFRS. 2011. Disponível em: <http://www.ifrs.org/Features/Pages/Africa-embraces-IFRSs.aspx>. Acesso em: Fev. 2016.

IFRSFOUNDATION. Use Around the World: Jurisdiction Profiles. Disponível em: < http://www.ifrs.org/Use-around-the-world/Pages/Jurisdiction-profiles.aspx >. Acesso em: 20 Out. 2015.

IFRSFOUNDATION. Who We Are and What We Do. Disponível em: <http://www.ifrs.org/About-us/Pages/Who-We-Are.aspx>. Acesso em: 30 Jul. 2014.

INTERNATIONAL Monetary Fund - IMF. World Economic Outlook: Hopes, realities, risks. Washington, DC : International Monetary Fund. Apr., 2013.

ISMAIL, B. E.; KIM, M. KIRK, F. R. Accounting Data and the Prediction of Risk in the Extremes, Review of Financial Economics, V. 4, N. 1, p. 55-68, 1994.

JAGANNATHAN, R. WANG, Z. The Conditional CAPM and the Cross-Section of Expected Returns. The Journal of Finance, V. 51, N. 1, p. 3-53, Mar., 1996.

JANSSON, A.; JÖNSSON M.; VON KOCH, C. Has the introduction of IFRS improved accounting quality? A comparative study of five countries. Working Paper In: 35th Annual Congress of the European Accounting Association, Ljubljana, May., 2012.

JENSEN, M. C. Some Anomalous Evidence Regarding Market Efficiency. Journal of Financial Economics, V. 6, N. 2/3, p. 95-101, 1978.

JEON, S.; KIM, J.; LEE, S. The persistence of abnormal earnings and systematic risk. Tourism Management, V. 27, I. 5, p. 867-873, oct. 2006. 
JERMAKOWICZ, E. K.; GORNIK-TOMASZEWSKI, S. Implementing IFRS from the perspective of EU publicly traded companies. Journal of International Accounting, Auditing and Taxation, V. 15, N. 2, p. 170-196, 2006.

JOIA, R. M.; NAKAO, S. H. Adoção de IFRS e gerenciamento de resultado nas empresas brasileiras de capital aberto. REPeC - Revista de Educação e Pesquisa em Contabilidade, V. 8, N. 1, p. 22-38, 2014.

KABIR, H.; LASWAD, F.; ISLAM, A. Impact of IFRS Adoption in New Zealand on Accounts and Earnings Quality. Australian Accounting Review, V 20, I. 4, p. 343-357, Dec., 2010 .

KADRI, M. H.; AZIZ, R. A.; IBRAHIM, M. K. Value relevance of book value and earnings: evidence from two different financial reporting regimes. Journal of Financial Reporting \& Accounting, V. 7, N. 1, p. 1-16, 2009.

KAHNEMAN, D.; TVERSKY, A. Prospect Theory: An Analysis of Decision under Risk. Econometrica: Journal of The Econometric Society, V. 47, N. 2, p. 263-292, 1979.

KALLUNKI, J-P et al. The Finnish Stock Market: A Survey of Some Empirical Evidence and its Practical Relevance. 1997. Disponível em: <http://lta.hse.fi/1997/4/lta_1997_04_a5.pdf> . Acesso em: 30 Jul. de 2014.

KARGIN, S. The Impact of IFRS on the Value Relevance of Accounting Information: Evidence from Turkish Firms. International Journal of Economics and Finance, V. 5, N. 4; p. 71-80, 2013.

KHANAGHA, J. B. Value Relevance of Accounting Information in the United Arab Emirates. International Journal of Economics and Financial Issues, V. 1, N. 2, p. 33-45, 2011.

KIM, M.; ISMAIL, B. E. An Accounting Analysis of the Risk-Return Relationship in Bull and Bear Markets, Review of Financial Economics, V. 7, N. 2, p. 173-182, 1998.

KLANN, R. C. BEUREN, I. M. Impacto da Convergência Contábil Internacional na Suavização de Resultados em Empresas Brasileiras. Brazilian Business Review, V. 12, N. 2, p. 1-25, Mar-Abr 2015.

KOENKER, R.; BASSETT JÚNIOR, J. Regression Quantiles. Econometrica: Journal of The Econometric Society, V. 46, N. 1, p. 33-50, Jan., 1978.

KONSTANTINOS, P. P.; ATHANASIOS, B. P. The Value Relevance of Accounting Information Under Greek and International Financial Reporting Standards: The Influence of Firm-Specific Characteristics. International Research Journal of Finance and Economics, N. 76, p. 6-23, 2011.

KOTHARI, S. P. Capital markets research in accounting. Journal of Accounting and Economics, V 31, p. 105-231, 2001. 
KOTHARI, S. P. RAMANNA K.; SKINNER, D. J. Implications for GAAP from an analysis of positive research in accounting. Journal of Accounting and Economics, V. 50, N. 2-3, p. 246-286, Dec. 2010.

KWAK, Y. H.; DEWAN, S. Risk Management in International Development Projects. Proceedings of the Project Management Institute Annual Seminars \& Symposium, Nashville,Tenn.,USA, 2001.

LANDSMAN, W. R. MAYDEW, E. L. THORNOCK, J. R. The information contente of anual earnings announcements and mandatory adoption of IFRS. Journal of Accounting and Economics, V. 53, N. 1-2, p. 34-54, 2012.

LAVEREN, E. et al. Can accounting variables explain any beta? The empirical association between various betas and nine accounting variables in Belgian listed firms. Working Paper In: UFSIA, Department of Business Economics, Antwerpen, 1997.

LEE, E. et al. Mandating IFRS: Its Impact on the Cost of Equity Capital in Europe. Journal of Internationl Accounting Research: Spring, V. 9, N. 1, p. 58-59, 2010.

LEUZ, C. IAS Versus U.S. GAAP: Information Asymmetry-Based Evidence from Germany's New Market. Journal of Accounting Research, V. 41, N. 3, p. 445-472, 2003.

LEUZ, C.; WYSOCKI, P. Economic Consequences of Financial Reporting and Disclosure Regulation: A Review and Suggestions for Future Research. 2008. Disponível em: < http://papers.ssrn.com/sol3/papers.cfm?abstract_id=1105398 >. Acesso em: 30 Jul. 2014.

LEV, B. On the Usefulness of Earnings and Earnings Research: Lessons and Directions from Two Decades of Empirical Research. Journal of Accounting Research. V. 27, p. 153-192, 1989.

LI, S. Does Mandatory Adoption of International Financial Reporting Standards in the European Union Reduce the Cost of Equity Capital?. The Accounting Review, V. 85, N. 2, p. 607-636, Mar. 2010.

LI, T.; SUN, L. ZOU, L. State ownership and corporate performance: A quantile regression analysis of Chinese listed companies. China Economic Review, V. 20, N. 4, p. 703-716, 2009.

LIMA, V. S. Incentivos no nível da firma e consequências econômicas da convergência ao IFRS no Brasil. 2011. 172 p. Dissertação (Mestrado em Ciências Contábeis) - Faculdade de Economia, Administração e Contabilidade, Universidade de São Paulo, São Paulo, 2011.

LIMA, V. S.; ILHA, H. F.; GALDI, F. C. Construção empírica e análise teórica do beta contábil: uma investigação no mercado acionário brasileiro sob a ótica de diferentes pressupostos econométricos. Anais do Congresso USP de Controladoria e Contabilidade, USP, São Paulo, SP, Brasil, 2009.

LINTNER, J. Security Prices, Risk, and Maximal Gains From Diversification The Journal of Finance, V. 20, N. 4, p. 587-615, 1965. 
LIU, C.; et al. The Impact of IFRS on Accounting Quality in a Regulated Market: An Empirical Study of China. Journal of Accounting, Auditing \& Finance, V. 26, N. 4, p. 659676, 2011.

LOUNSBURY, M. Institutional rationality and practice variation: New directions in the institutional analysis of practice. Accounting, Organizations and Society, V 33, N. 4-5, p. 349-361, 2008.

MACEDO, M. A. S. et al. Impacto da Convergência às Normas Contábeis Internacionais no Brasil Sobre o Conteúdo Informacional da Contabilidade. REPeC-Revista de Educação e Pesquisa em Contabilidade, V. 7, N. 3, p. 222-239, 2013.

MACEDO, M. A. S. et al. Análise do impacto da substituição da DOAR pela DFC: um estudo sob a perspectiva do value-relevance. Revista Contabilidade e Finanças - USP, São Paulo, V. 22, N. 57, p. 299-318, set./out./nov./dez. 2011.

MACEDO, M. A. S.; MACHADO, M. A. V.; MACHADO, M. R. Análise da Relevância da Informação Contábil no Brasil num Contexto de Convergência às Normas Internacionais de Contabilidade. Revista Universo Contábil, V. 9, N. 1, p. 65-85, 2013.

MACHADO, M. A. V.; SILVA FILHO, A. C. C.; CALLADO, A. L. C. O processo de convergência às IFRS e a capacidade do lucro e do fluxo de caixa em prever os fluxos de caixa futuro: evidências no mercado brasileiro. Revista de Contabilidade e Organizações, v. 8, n. 21, p. 4-13, 2014.

MARKOWITZ, H. M. Portfolio Selection: Efficient Diversification of Investments. John Wiley \& Sons, Inc., New Jersey, 1959.

MARTÍNEZ, J. A. MARTÍNEZ, D. A. LIN, H. The Value Relevance of Accounting Numbers Under International Financial Reporting Standards. Australian Accounting Review, Vol. 24, N. 70, I. 3, p. 237-254, Sep. 2014.

MARTINS, V. G. et. al. Níveis Diferenciados de Governança Corporativa e a Qualidade da Informação Contábil Durante o Processo de Convergência às Normas Internacionais de Contabilidade. ConTexto, Porto Alegre, V. 14, N. 27, p. 23-42, maio/ago. 2014.

MENÉNDEZ-PLANS, C.; ORGAZ, N.; PRIOR, D. Existe relación entre la información contable y el riesgo sistemático de las empresas? estimación con datos de panel, Academia, Revista Latinoamericana de Administración, V. 49, p. 46-60, 2012.

MENSAH, Y. M. Adjusted accounting beta, operating leverage and financial leverage as determinants of market beta: A synthesis and empirical evaluation. Review of Quantitative Finance and Accounting. V. 2, I. 2, p. 187-203, Jun. 1992.

MEYER, J. W.; ROWAN, B. Institutionalized Organizations: Formal Structure as Myth and Ceremony. American Journal of Sociology, V. 83, N. 2, p. 340-363, 1977.

MORAIS, A. I.; CURTO, J. D. Mandatory Adoption of IASB Standards: Value Relevance and Country-Specific Factors, Australian Accounting Review, V. 19, N. 49, I. 2, p. 128-143, 2009. 
MORGAN, M.; HENRION, M. Uncertainty: a Guide to Dealing with Uncertainty in Quantitative Risk and Policy Analysis. Cambridge University Press, New York, 1990.

MOSSIN, J. Equilibrium in a Capital Asset Market. Econometrica: Journal of The Econometric Society, V. 34, N. 4, p. 768-783, oct., 1966.

MSCI. Gauge of Global Stock Market Activity. 2015. Disponível em: <https://www.msci.com/>. Acesso em: 29 de nov. de 2015.

NAFTI, O. BOUMEDIENE, E. BOUMEDIENE, S. L. IAS-IFRS Adoption Impact on Accounting Information: The Case of France. Journal of Modern Accounting and Auditing, V. 9, N. 3, p. 321-334, Mar., 2013.

NASCIMENTO, A. S.; SILVA, A. H. C. Adoção do IFRS no Brasil: uma análise dos efeitos na comparabilidade e na relevância das demonstrações contábeis de empresas de capital aberto. In: Anais... 19 Congresso Brasileiro de Contabilidade -Belém- PA, 2012.

NG, D. T. The international capm when expected returns are timevarying. Journal of International Money and Finance, V. 23, N. 2, p. 189-230, 2004.

NG, L. Tests of the CAPM with Time-Varying Covariances: A Multivariate GARCH Approach. The Journal of Finance, V. 46, N. 4, p. 1507-1521, Sep., 1991.

NULLA, Y. M. IFRS adoption in Research and Development Companies. Journal of Administrative Sciences and Policy Studies, V. 1, N. 1, p. 34-48, 2013.

O’NEILL, J. Building Better Global Economic BRICs. Goldman Sachs Economic Research. N. 66. Nov, 2001.

ODABA, A. An Investigation of Beta Instability in the Istanbul Stock Exchange. Boğazici University, Istanbul, 2003.

OSSIP, JG. The value relevance of mandatory IFRS adoption in South Africa, MCom (Accounting) mini-dissertation, University of Pretoria, Pretoria, viewed yymmdd < http://hdl.handle.net/2263/29297 > 2011.

PAGLIETTI, P. Effects of IFRS mandatory adoption and country-specific factors on accounting quality: evidence from Italy. In: 9th Global Conference on Business \& Economics, Cambridge, Regno Unito. 2009.

PALEA, V. Are IFRS value-relevant for separate financial statements? Evidence from the Italian stock Market. Journal of International Accounting, Auditing and Taxation, V 23, n 1 , p. 1-17, 2014.

PAPADAMOU, S. TZIVINIKOS, T. The risk relevance of International Financial Reporting Standards: Evidence from Greek banks. International Review of Financial Analysis, V. 27, p. 43-54, Apr., 2013. 
PAULO, E. et al. The Impact of the Adoption of International Financial Reporting Standards on the Quality of Accounting Information of the Brazilian and European Public Firms. 2013. Disponível em: < http://papers.ssrn.com/sol3/papers.cfm?abstract_id=2270678>. Acesso em: 30 Jul. 2014.

PRATHER-KINSEY, J. SHELTON, S. W. IAS Versus U.S. GAAP: Assessing the Quality of Financial Reporting in South Africa, the United Kingdom, and the United States. Advances in International Accounting, V. 18, p. 153-168, 2005.

QU, W.; FONG, M.; OLIVER, J. Does IFRS Convergence Improve Quality of Accounting Information? - Evidence from the Chinese Stock Market. Corporate Ownership \& Control. V. 9, N. 4, p. 187-196, 2012.

RAINSBURY, E.; SAN DIEGO, J.; WALKER, L. Evidence on the Impact of International Financial Reporting Standards in New Zealand. Second Quantitative Accounting Research Symposium, Auckland, New Zealand, May., 2010.

RODRIGUES, J. M. Convergência Contábil Internacional: Uma Análise da Qualidade da Informação Contábil em Razão da Adoção dos Padrões Internacionais de Contabilidade Editados pelo IASB. Tese (Doutorado em Ciências Contábeis). Universidade de Brasília. Brasília, DF, 2012.

RODRIGUES, J. M.; NIYAMA, J. K. Convergência Internacional: uma análise comparativa entre os padrões contábeis da China e do IASB. In: Anais... Congresso USP Controladoria e Contabilidade, 2008, São Paulo. São Paulo: FEA/USP, 2008.

SALOTTI, B. M.; YAMAMOTO, M. M. Ensaio Sobre a Teoria da Divulgação. $B B R-$ Brazilian Business Review, V. 2, N. 1, p. 53-70, 2005.

SANTOS, A. C.; STAROSKY FILHO, L.; KLANN, R. C. Efeitos do processo de convergência às normas internacionais de Contabilidade no value relevance das demonstrações contábeis de organizações brasileiras. Revista Contemporânea de Contabilidade, V. 11, N. 22, p. 95-118, 2014.

SANTOS, L. P. G. et al. Efeito da Lei 11.638/07 sobre o conservadorismo condicional das empresas listadas BM\&FBOVESPA. Revista Contabilidade \& Finanças - USP, V. 22, N. 56, p. 174-188, 2011.

SANTOS, M. A. C.; CAVALCANTE, P. R. N. O Efeito da Adoção dos IFRS sobre a Relevância Informacional do Lucro Contábil no Brasil. Revista Contabilidade e Finanças USP, São Paulo, V. 25, N. 66, p. 228-241, set./out./nov./dez. 2014.

SANTOS, O. M.; SANTOS, A. Lobbying na Regulação Contábil: Evidências do Setor Petrolífero. Revista Contabilidade e Finanças - USP, V. 25, N. 65, p. 124-144, maio/jun./jul./ago. 2014.

SCHIPPER, K. The introduction of International Accounting Standards in Europe:

Implications for international convergence. European Accounting Review, V. 14, N. 1, p. 101$126,2005$. 
SCOTT, W. R. Financial Accounting Theory. 7 ed. Toronto, Ont: Pearson Prentice Hall. 2007.

SHARPE, W. F. A Theory of Market Equilibrium under Conditions of Risk. The Journal of Finance, V. 19, N. 3, p. 425-442, 1964.

SHIL, N. C.; DAS, B. PRAMANIK, A. K. Harmonization of Accounting Standards through Internationalization. International Business Research, V. 2, N. 2, p. 194-201, 2009.

SILVA, R. L. M. Adoção completa das IFRS no brasil: qualidade das demonstrações contábeis e o custo de capital próprio. Tese (Doutorado em Ciências Contábeis) - Faculdade de Economia, Administração e Contabilidade, Universidade de São Paulo, São Paulo, 2013.

SODERSTROM, N. S.; SUN, K. J. IFRS Adoption and Accounting Quality: A Review. European Accounting Review, V. 16, N. 4, p. 675-702, 2007.

SOVBETOV, Y. How IFRS Affects Value Relevance and Key Financial Indicators?

Evidence from the UK, International Review of Accounting, Banking and Finance, V. 7, N. 1, p. 73-96, 2015.

SUSMEL, R. ENGLE, R. F. Hourly volatility spillovers between international equity markets. Journal of International Money and Finance, V. 13, N. 1, p. 3-25, 1994.

TERZI, S.; OKTEM, R.; SEN, I. K. Impact of Adopting International Financial Reporting Standards: Empirical Evidence from Turkey. International Business Research, V. 6, N. 4, p. 55-66, 2013.

TORRES, H. F. S. A crise financeira e as economias emergentes. Meridiano 47. V. 9, N. 100, p. 29-31, 2008.

TSE, Y. K.. TSUI, A. K. C. A multivariate generalized autoregressive conditional heteroscedasticity model with time-varying correlations. Journal of Business \& Economic Statistics, V. 20, N. 3, p. 351-362, Jul., 2002.

VAN DER MEULEN, S.; GAEREMYNCK, A.; WILLEKENS, M. Attribute differences between U.S. GAAP and IFRS earnings: An exploratory study. The International Journal of Accounting, V. 42, N. 2, p. 123-142, 2007.

VERRECCHIA, R. E. Essays on Disclosure. Journal of Accounting and Economics, V. 32, N. 1-3, p. 97-180, 2001.

VIEIRA, R. B. Impactos da implantação parcial dos IFRS no Brasil: Efeitos na qualidade das informações contábeis das empresas de capital aberto. 2010. 70 f. Dissertação de Mestrado (Mestrado em Contabilidade) - Faculdade de Economia, Administração e Contabilidade de Ribeirão Preto, Universidade de São Paulo, Ribeirão Preto, 2010.

WANG, K. Q. Asset Pricing with Conditioning Information: A New Test. The Journal of Finance, V. LVIII, N. 1 Feb. 2003. 
WATTS, R.; ZIMMERMAN, J. Positive Accounting Theory. Prentice-Hall, Englewood Cliffs, NJ. 1986.

WEBER, E. U.; HSEE, C. Cross-cultural Differences in Risk Perception, but Cross-cultural Similarities in Attitudes Towards Perceived Risk. Management Science, V. 44, N. 9, p. $1205-$ 1217, 1998.

WILSON, D. STUPNYTSKA, A. The N-11: More Than an Acronym. Goldman Sachs Economic Research. N. 153. Mar, 2007.

WOAN, R. J. The usefulness of accounting information in assessing systematic risk: a reexamination. Academy of Accounting and Financial Studies Journal, V 5, N 2, May, 2001.

YAHOO FINANCE. Disponível em: $<$ http://finance.yahoo.com/q?s=msci\&fr=uh3_finance_web\&uhb=uhb2>. Acesso em: Out., 2015.

ZEFF, S. A. Commentary Some obstacles to global financial reporting comparability and convergence at a high level of quality. The British Accounting Review, V. 39, N. 4, p. 290302, 2007.

ZEFF, S. A. The Evolution of the IASC into the IASB, and the Challenges it Faces. The Accounting Review, V. 87, N. 3, p. 807-837, 2012.

ZEGHAL, D.; MHEDHBI, K. An analysis of the factors affecting the adoption of international accounting standards by developing countries. The International Journal of Accounting, V. 41, N. 4, p. 373-386, 2006.

ZHOU, H.; XIONG, Y.; GANGULI, G. Does the adoption of international financial reporting standards restrain earnings management? Evidence from an emerging market. Academy of Accounting and Financial Studies Journal, V. 13, N. Especial, 2009. 


\section{APÊNDICE A}

\section{Tabelas completas da Regressão Quantílica por país (Saída do EViews)}

\section{Austrália}

Dependent Variable: AUSTRALIA

Method: Quantile Regression (Median)

Date: 03/06/16 Time: $16: 38$

Sample: 2000M02 2015M09

Included observations: 188

Huber Sandwich Standard Errors \& Covariance

Sparsity method: Kernel (Epanechnikov) using residuals

Bandwidth method: Hall-Sheather, bw $=0.1696$

Estimation successfully identifies unique optimal solution

\begin{tabular}{lclll}
\hline \hline \multicolumn{1}{c}{ Variable } & Coefficient & Std. Error & t-Statistic & Prob. \\
\hline \hline \multicolumn{1}{c}{ DUMMYAUS } & 0.230626 & 0.030220 & 7.631616 & 0.0000 \\
\multicolumn{1}{c}{ C } & 0.519121 & 0.021782 & 23.83245 & 0.0000 \\
\hline \hline Pseudo R-squared & 0.205357 & Mean dependent var & 0.670290 \\
Adjusted R-squared & 0.201085 & S.D. dependent var & 0.166724 \\
S.E. of regression & 0.135938 & Objective & 10.72187 \\
Quantile dependent var & 0.670373 & Restr. objective & 13.49269 \\
Sparsity & 0.420182 & Quasi-LR statistic & 52.75474 \\
Prob(Quasi-LR stat) & 0.000000 & & \\
\hline \hline
\end{tabular}

Dependent Variable: BETA

Method: Quantile Regression (Median)

Date: 04/20/16 Time: 18:28

Sample: 2000M01 2014M12

Included observations: 180

Huber Sandwich Standard Errors \& Covariance

Sparsity method: Kernel (Epanechnikov) using residuals

Bandwidth method: Hall-Sheather, bw $=0.17207$

Estimation successful but solution may not be unique

\begin{tabular}{crlrr}
\hline \hline \multicolumn{1}{c}{ Variable } & Coefficient & \multicolumn{1}{c}{ Std. Error } & t-Statistic & Prob. \\
\hline \hline \multicolumn{1}{c}{ DUMMY } & 0.338066 & 0.039424 & 8.575104 & 0.0000 \\
TC & 1.941065 & 0.497336 & 3.902924 & 0.0001 \\
TJ & -0.038669 & 0.020172 & -1.916905 & 0.0569 \\
C & -1.826984 & 0.561290 & -3.254972 & 0.0014 \\
\hline \hline Pseudo R-squared & 0.252376 & Mean dependent var & 0.661552 \\
Adjusted R-squared & 0.239633 & S.D. dependent var & 0.164563 \\
S.E. of regression & 0.140996 & Objective & 9.446835 \\
Quantile dependent var & 0.638227 & Restr. objective & 12.63581 \\
Sparsity & 0.315945 & Quasi-LR statistic & 80.74776 \\
Prob(Quasi-LR stat) & 0.000000 & & \\
\hline \hline
\end{tabular}

\section{Alemanha}

Dependent Variable: ALEMANHA

Method: Quantile Regression (Median) 
Date: 03/06/16 Time: 16:40

Sample: 2000M02 2015M09

Included observations: 188

Huber Sandwich Standard Errors \& Covariance

Sparsity method: Kernel (Epanechnikov) using residuals

Bandwidth method: Hall-Sheather, $b w=0.1696$

Estimation successfully identifies unique optimal solution

\begin{tabular}{lrlrr}
\hline \hline \multicolumn{1}{c}{ Variable } & Coefficient & Std. Error & t-Statistic & Prob. \\
\hline \hline \multicolumn{1}{c}{ DUMMYALEM } & -0.146760 & 0.053822 & -2.726755 & 0.0070 \\
\multicolumn{1}{c}{ C } & 1.260506 & 0.046420 & 27.15411 & 0.0000 \\
\hline \hline Pseudo R-squared & 0.043480 & Mean dependent var & 1.135815 \\
Adjusted R-squared & 0.038337 & S.D. dependent var & 0.242796 \\
S.E. of regression & 0.244197 & Objective & 17.99990 \\
Quantile dependent var & 1.157964 & Restr. objective & 18.81811 \\
Sparsity & 0.645569 & Quasi-LR statistic & 10.13938 \\
Prob(Quasi-LR stat) & 0.001451 & & \\
\hline \hline
\end{tabular}

Dependent Variable: BETA

Method: Quantile Regression (Median)

Date: 04/23/16 Time: 10:33

Sample: 2000M01 2014M12

Included observations: 180

Huber Sandwich Standard Errors \& Covariance

Sparsity method: Kernel (Epanechnikov) using residuals

Bandwidth method: Hall-Sheather, bw=0.17207

Estimation successful but solution may not be unique

\begin{tabular}{lrlrr}
\hline \hline \multicolumn{1}{c}{ Variable } & Coefficient & \multicolumn{1}{c}{ Std. Error } & t-Statistic & Prob. \\
\hline \hline \multicolumn{1}{c}{ DUMMY } & -0.136407 & 0.057304 & -2.380432 & 0.0184 \\
TC & 0.535916 & 0.280388 & 1.911339 & 0.0576 \\
TJ & -0.013595 & 0.035549 & -0.382427 & 0.7026 \\
C & 0.648010 & 0.276842 & 2.340722 & 0.0204 \\
\hline \hline Pseudo R-squared & 0.066782 & Mean dependent var & 1.126757 \\
Adjusted R-squared & 0.050875 & S.D. dependent var & 0.243155 \\
S.E. of regression & 0.244790 & Objective & 16.81139 \\
Quantile dependent var & 1.127957 & Restr. objective & 18.01443 \\
Sparsity & 0.598948 & Quasi-LR statistic & 16.06877 \\
Prob(Quasi-LR stat) & 0.001098 & & & \\
\hline \hline
\end{tabular}

\section{Brasil}

Dependent Variable: BRAZIL

Method: Quantile Regression (Median)

Date: 10/29/15 Time: 13:39

Sample: 2000M02 2015M09

Included observations: 188

Huber Sandwich Standard Errors \& Covariance

Sparsity method: Kernel (Epanechnikov) using residuals

Bandwidth method: Hall-Sheather, bw $=0.1696$

Estimation successfully identifies unique optimal solution

\begin{tabular}{lllll}
\hline \hline Variable & Coefficient & Std. Error & t-Statistic & Prob. \\
\hline \hline
\end{tabular}




\begin{tabular}{crlrr}
\multicolumn{1}{c}{ DUMMYBR } & -0.254972 & 0.054003 & -4.721423 & 0.0000 \\
C & 1.401375 & 0.035559 & 39.40973 & 0.0000 \\
\hline Pseudo R-squared & 0.112664 & Mean dependent var & 1.296293 \\
Adjusted R-squared & 0.107893 & S.D. dependent var & 0.281477 \\
S.E. of regression & 0.266091 & Objective & 19.84801 \\
Quantile dependent var & 1.282467 & Restr. objective & 22.36807 \\
Sparsity & 0.735591 & Quasi-LR statistic & 27.40726 \\
Pob(Quasi-LR stat) & 0.000000 & & \\
\hline
\end{tabular}

Dependent Variable: BETA

Method: Quantile Regression (Median)

Date: 04/22/16 Time: 14:32

Sample: 2000M01 2014M12

Included observations: 180

Huber Sandwich Standard Errors \& Covariance

Sparsity method: Kernel (Epanechnikov) using residuals

Bandwidth method: Hall-Sheather, bw $=0.17207$

Estimation successfully identifies unique optimal solution

\begin{tabular}{crlrr}
\hline \hline \multicolumn{1}{c}{ Variable } & Coefficient & Std. Error & t-Statistic & Prob. \\
\hline \hline DUMMY & -0.397717 & 0.079574 & -4.998061 & 0.0000 \\
TC & 0.173586 & 0.046490 & 3.733856 & 0.0003 \\
TJ & -0.014781 & 0.009119 & -1.620880 & 0.1068 \\
C & 1.223447 & 0.196509 & 6.225919 & 0.0000 \\
\hline \hline Pseudo R-squared & 0.187084 & Mean dependent var & 1.285024 \\
Adjusted R-squared & 0.173228 & S.D. dependent var & 0.280502 \\
S.E. of regression & 0.258432 & Objective & 17.24771 \\
Quantile dependent var & 1.266810 & Restr. objective & 21.21710 \\
Sparsity & 0.579320 & Quasi-LR statistic & 54.81448 \\
Prob(Quasi-LR stat) & 0.000000 & & \\
\hline \hline
\end{tabular}

\section{China}

Dependent Variable: CHINA

Method: Quantile Regression (Median)

Date: 10/29/15 Time: $13: 40$

Sample: 2000M02 2015M09

Included observations: 188

Huber Sandwich Standard Errors \& Covariance

Sparsity method: Kernel (Epanechnikov) using residuals

Bandwidth method: Hall-Sheather, bw $=0.1696$

Estimation successfully identifies unique optimal solution

\begin{tabular}{lrlrr}
\hline \hline \multicolumn{1}{c}{ Variable } & Coefficient & Std. Error & t-Statistic & Prob. \\
\hline \hline \multicolumn{1}{c}{ DUMMYCH } & -0.054562 & 0.034925 & -1.562283 & 0.1199 \\
C & 1.101349 & 0.019040 & 57.84371 & 0.0000 \\
\hline \hline Pseudo R-squared & 0.010040 & Mean dependent var & 1.073074 \\
Adjusted R-squared & 0.004718 & S.D. dependent var & 0.227138 \\
S.E. of regression & 0.230013 & Objective & 15.53334 \\
Quantile dependent var & 1.079764 & Restr. objective & 15.69088 \\
Sparsity & 0.453846 & Quasi-LR statistic & 2.776940 \\
Prob(Quasi-LR stat) & 0.095631 & & \\
\hline \hline
\end{tabular}


Dependent Variable: BETA

Method: Quantile Regression (Median)

Date: 04/23/16 Time: 09:19

Sample: 2000M01 2014M12

Included observations: 180

Huber Sandwich Standard Errors \& Covariance

Sparsity method: Kernel (Epanechnikov) using residuals

Bandwidth method: Hall-Sheather, bw=0.17207

Estimation successfully identifies unique optimal solution

\begin{tabular}{cclll}
\hline \hline \multicolumn{1}{c}{ Variable } & Coefficient & Std. Error & t-Statistic & Prob. \\
\hline \hline DUMMY & -0.206667 & 0.032270 & -6.404294 & 0.0000 \\
TC & 0.052539 & 0.021899 & 2.399103 & 0.0175 \\
TJ & 0.242655 & 0.038939 & 6.231647 & 0.0000 \\
C & 0.052624 & 0.218416 & 0.240934 & 0.8099 \\
\hline \hline Pseudo R-squared & 0.236269 & Mean dependent var & 1.064958 \\
Adjusted R-squared & 0.223251 & S.D. dependent var & 0.224324 \\
S.E. of regression & 0.172668 & Objective & 11.17416 \\
Quantile dependent var & 1.073279 & Restr. objective & 14.63102 \\
Sparsity & 0.338746 & Quasi-LR statistic & 81.63886 \\
Prob(Quasi-LR stat) & 0.000000 & & & \\
\hline \hline
\end{tabular}

\section{Canadá}

Dependent Variable: CAN

Method: Quantile Regression (Median)

Date: 10/29/15 Time: 13:42

Sample: 2000M02 2015M09

Included observations: 188

Huber Sandwich Standard Errors \& Covariance

Sparsity method: Kernel (Epanechnikov) using residuals

Bandwidth method: Hall-Sheather, bw $=0.1696$

Estimation successfully identifies unique optimal solution

\begin{tabular}{lrlrr}
\hline \hline \multicolumn{1}{c}{ Variable } & Coefficient & Std. Error & t-Statistic & Prob. \\
\hline \hline \multicolumn{1}{c}{ DUMMYCAN } & -0.135107 & 0.023662 & -5.709810 & 0.0000 \\
C & 0.777426 & 0.017458 & 44.53159 & 0.0000 \\
\hline \hline Pseudo R-squared & 0.117534 & Mean dependent var & 0.751345 \\
Adjusted R-squared & 0.112789 & S.D. dependent var & 0.151869 \\
S.E. of regression & 0.139310 & Objective & 10.04102 \\
Quantile dependent var & 0.736042 & Restr. objective & 11.37836 \\
Sparsity & 0.333249 & Quasi-LR statistic & 32.10428 \\
Prob(Quasi-LR stat) & 0.000000 & & \\
\hline \hline
\end{tabular}

Dependent Variable: BETA

Method: Quantile Regression (Median)

Date: 04/23/16 Time: 10:28

Sample: 2000M01 2014M12

Included observations: 180

Huber Sandwich Standard Errors \& Covariance

Sparsity method: Kernel (Epanechnikov) using residuals

Bandwidth method: Hall-Sheather, bw=0.17207 
Estimation successful but solution may not be unique

\begin{tabular}{lrlrr}
\hline \hline \multicolumn{1}{c}{ Variable } & Coefficient & Std. Error & t-Statistic & Prob. \\
\hline \hline \multicolumn{1}{c}{ DUMMY } & -0.012540 & 0.047724 & -0.262767 & 0.7930 \\
TC & 0.085223 & 0.169891 & 0.501632 & 0.6166 \\
TJ & 0.063404 & 0.009427 & 6.725888 & 0.0000 \\
C & 0.449008 & 0.246786 & 1.819418 & 0.0705 \\
\hline \hline Pseudo R-squared & 0.308014 & Mean dependent var & 0.752814 \\
Adjusted R-squared & 0.296219 & S.D. dependent var & 0.154710 \\
S.E. of regression & 0.113226 & Objective & 7.758651 \\
Quantile dependent var & 0.736042 & Restr. objective & 11.21215 \\
Sparsity & 0.268115 & Quasi-LR statistic & 103.0450 \\
Prob(Quasi-LR stat) & 0.000000 & & \\
\hline \hline
\end{tabular}

\section{Reino Unido}

Dependent Variable: UK

Method: Quantile Regression (Median)

Date: 10/29/15 Time: 13:43

Sample: 2000M02 2015M09

Included observations: 188

Huber Sandwich Standard Errors \& Covariance

Sparsity method: Kernel (Epanechnikov) using residuals

Bandwidth method: Hall-Sheather, bw $=0.1696$

Estimation successfully identifies unique optimal solution

\begin{tabular}{lclll}
\hline \hline \multicolumn{1}{c}{ Variable } & Coefficient & Std. Error & t-Statistic & Prob. \\
\hline \hline \multicolumn{1}{c}{ DUMMYRU } & 0.070307 & 0.022647 & 3.104484 & 0.0022 \\
\multicolumn{1}{c}{ C } & 0.757468 & 0.017037 & 44.45966 & 0.0000 \\
\hline \hline Pseudo R-squared & 0.026501 & Mean dependent var & 0.802732 \\
Adjusted R-squared & 0.021267 & S.D. dependent var & 0.107910 \\
S.E. of regression & 0.110361 & Objective & 8.300918 \\
Quantile dependent var & 0.810644 & Restr. objective & 8.526886 \\
Sparsity & 0.310209 & Quasi-LR statistic & 5.827501 \\
Prob(Quasi-LR stat) & 0.015778 & & \\
\hline \hline
\end{tabular}

Dependent Variable: BETA

Method: Quantile Regression (Median)

Date: 04/23/16 Time: 10:35

Sample: 2000M01 2014M12

Included observations: 180

Huber Sandwich Standard Errors \& Covariance

Sparsity method: Kernel (Epanechnikov) using residuals

Bandwidth method: Hall-Sheather, bw $=0.17207$

Estimation successful but solution may not be unique

\begin{tabular}{crrrr}
\hline \hline Variable & Coefficient & Std. Error & t-Statistic & Prob. \\
\hline \hline DUMMY & 0.073944 & 0.023949 & 3.087525 & 0.0023 \\
TC & 0.446439 & 0.161028 & 2.772429 & 0.0062 \\
TJ & -0.011094 & 0.013702 & -0.809637 & 0.4192 \\
C & 0.060452 & 0.216161 & 0.279660 & 0.7801 \\
\hline \hline
\end{tabular}

Pseudo R-squared

0.116909 Mean dependent var

0.797907 
Adjusted R-squared

0.101857 S.D. dependent var

\section{Itália}

Dependent Variable: ITA

Method: Quantile Regression (Median)

Date: 10/29/15 Time: 13:44

Sample: 2000M02 2015M09

Included observations: 188

Huber Sandwich Standard Errors \& Covariance

Sparsity method: Kernel (Epanechnikov) using residuals

Bandwidth method: Hall-Sheather, bw $=0.1696$

Estimation successfully identifies unique optimal solution

\begin{tabular}{lrlll}
\hline \hline \multicolumn{1}{c}{ Variable } & Coefficient & Std. Error & t-Statistic & Prob. \\
\hline \hline \multicolumn{1}{c}{ DUMMYITAL } & 0.101949 & 0.038250 & 2.665343 & 0.0084 \\
\multicolumn{1}{c}{ C } & 0.902474 & 0.032952 & 27.38733 & 0.0000 \\
\hline \hline Pseudo R-squared & 0.033341 & Mean dependent var & 0.990894 \\
Adjusted R-squared & 0.028144 & S.D. dependent var & 0.198734 \\
S.E. of regression & 0.188490 & Objective & 13.46784 \\
Quantile dependent var & 0.964505 & Restr. objective & 13.93236 \\
Sparsity & 0.459710 & Quasi-LR statistic & 8.083712 \\
Prob(Quasi-LR stat) & 0.004466 & & \\
\hline \hline
\end{tabular}

Dependent Variable: BETA

Method: Quantile Regression (Median)

Date: 04/23/16 Time: 10:38

Sample: 2000M01 2014M12

Included observations: 180

Huber Sandwich Standard Errors \& Covariance

Sparsity method: Kernel (Epanechnikov) using residuals

Bandwidth method: Hall-Sheather, bw=0.17207

Estimation successfully identifies unique optimal solution

\begin{tabular}{lrlrr}
\hline \hline \multicolumn{1}{c}{ Variable } & Coefficient & Std. Error & t-Statistic & Prob. \\
\hline \hline \multicolumn{1}{c}{ DUMMY } & 0.062281 & 0.030771 & 2.024028 & 0.0445 \\
TC & -0.493572 & 0.225466 & -2.189123 & 0.0299 \\
TJ & -0.061281 & 0.013742 & -4.459396 & 0.0000 \\
C & 1.670922 & 0.285183 & 5.859116 & 0.0000 \\
\hline \hline Pseudo R-squared & 0.132102 & Mean dependent var & 0.983499 \\
Adjusted R-squared & 0.117308 & S.D. dependent var & 0.198829 \\
S.E. of regression & 0.174799 & Objective & 11.41402 \\
Quantile dependent var & 0.956618 & Restr. objective & 13.15134 \\
Sparsity & 0.371606 & Quasi-LR statistic & 37.40128 \\
Prob(Quasi-LR stat) & 0.000000 & & \\
\hline \hline
\end{tabular}

\section{FRANÇA}

Dependent Variable: FR 
Method: Quantile Regression (Median)

Date: 10/29/15 Time: 13:45

Sample: 2000M02 2015M09

Included observations: 188

Huber Sandwich Standard Errors \& Covariance

Sparsity method: Kernel (Epanechnikov) using residuals

Bandwidth method: Hall-Sheather, bw $=0.1696$

Estimation successfully identifies unique optimal solution

\begin{tabular}{lrlll}
\hline \hline \multicolumn{1}{c}{ Variable } & Coefficient & Std. Error & t-Statistic & Prob. \\
\hline \hline \multicolumn{1}{c}{ DUMMYFRAN } & 0.001518 & 0.039168 & 0.038751 & 0.9691 \\
C & 0.979781 & 0.031560 & 31.04453 & 0.0000 \\
\hline \hline Pseudo R-squared & 0.000058 & Mean dependent var & 0.977993 \\
Adjusted R-squared & -0.005318 & S.D. dependent var & 0.168377 \\
S.E. of regression & 0.168817 & Objective & 13.02614 \\
Quantile dependent var & 0.979781 & Restr. objective & 13.02690 \\
Sparsity & 0.512946 & Quasi-LR statistic & 0.011836 \\
Prob(Quasi-LR stat) & 0.913367 & & \\
\hline \hline
\end{tabular}

Dependent Variable: BETA

Method: Quantile Regression (Median)

Date: 04/26/16 Time: 16:46

Sample: 2000M01 2014M12

Included observations: 180

Huber Sandwich Standard Errors \& Covariance

Sparsity method: Kernel (Epanechnikov) using residuals

Bandwidth method: Hall-Sheather, bw=0.17207

Estimation successfully identifies unique optimal solution

\begin{tabular}{crlll}
\hline \hline \multicolumn{1}{c}{ Variable } & Coefficient & Std. Error & t-Statistic & Prob. \\
\hline \hline \multicolumn{1}{c}{ DUMMY } & 0.019395 & 0.037486 & 0.517387 & 0.6055 \\
TC & 0.274300 & 0.281404 & 0.974755 & 0.3310 \\
TJ & 0.029447 & 0.015956 & 1.845454 & 0.0667 \\
C & 0.563362 & 0.324235 & 1.737513 & 0.0840 \\
\hline \hline Pseudo R-squared & 0.010205 & Mean dependent var & 0.967770 \\
Adjusted R-squared & -0.006666 & S.D. dependent var & 0.163367 \\
S.E. of regression & 0.167960 & Objective & 11.98208 \\
Quantile dependent var & 0.973550 & Restr. objective & 12.10562 \\
Sparsity & 0.448070 & Quasi-LR statistic & 2.205732 \\
Prob(Quasi-LR stat) & 0.530820 & & \\
\hline \hline
\end{tabular}

\section{Nova Zelândia}

Dependent Variable: NZ

Method: Quantile Regression (Median)

Date: 10/29/15 Time: 13:46

Sample: 2000M02 2015M09

Included observations: 188

Huber Sandwich Standard Errors \& Covariance

Sparsity method: Kernel (Epanechnikov) using residuals

Bandwidth method: Hall-Sheather, bw $=0.1696$

Estimation successfully identifies unique optimal solution

\begin{tabular}{lllll}
\hline \hline Variable & Coefficient & Std. Error & t-Statistic & Prob.
\end{tabular}




\begin{tabular}{llllr}
\hline \hline \multicolumn{1}{c}{ DUMMYNZ } & 0.066479 & 0.050386 & 1.319407 & 0.1887 \\
\multicolumn{1}{c}{ C } & 0.391828 & 0.048464 & 8.084974 & 0.0000 \\
\hline \hline Pseudo R-squared & 0.013753 & Mean dependent var & 0.431288 \\
Adjusted R-squared & 0.008451 & S.D. dependent var & 0.141407 \\
S.E. of regression & 0.140514 & Objective & 10.77402 \\
Quantile dependent var & 0.438168 & Restr. objective & 10.92426 \\
Sparsity & 0.403675 & Quasi-LR statistic & 2.977470 \\
Prob(Quasi-LR stat) & 0.084431 & & \\
\hline \hline
\end{tabular}

Dependent Variable: BETA

Method: Quantile Regression (Median)

Date: 04/26/16 Time: 17:00

Sample: 2000M01 2014M12

Included observations: 180

Huber Sandwich Standard Errors \& Covariance

Sparsity method: Kernel (Epanechnikov) using residuals

Bandwidth method: Hall-Sheather, bw=0.17207

Estimation successfully identifies unique optimal solution

\begin{tabular}{lrlll}
\hline \hline \multicolumn{1}{c}{ Variable } & Coefficient & \multicolumn{1}{c}{ Std. Error } & t-Statistic & Prob. \\
\hline \hline \multicolumn{1}{c}{ DUMMY } & -0.027562 & 0.035000 & -0.787478 & 0.4321 \\
TC & -1.696034 & 0.279251 & -6.073499 & 0.0000 \\
TJ & 0.065099 & 0.008458 & 7.696524 & 0.0000 \\
C & 2.351685 & 0.346448 & 6.787992 & 0.0000 \\
\hline \hline Pseudo R-squared & 0.298623 & Mean dependent var & 0.431329 \\
Adjusted R-squared & 0.286667 & S.D. dependent var & 0.144345 \\
S.E. of regression & 0.106098 & Objective & 7.565855 \\
Quantile dependent var & 0.446129 & Restr. objective & 10.78714 \\
Sparsity & 0.283753 & Quasi-LR statistic & 90.81931 \\
Prob(Quasi-LR stat) & 0.000000 & & \\
\hline \hline
\end{tabular}

\section{Rússia}

Dependent Variable: RUSSIA

Method: Quantile Regression (Median)

Date: 10/29/15 Time: 13:47

Sample: 2000M02 2015M09

Included observations: 188

Huber Sandwich Standard Errors \& Covariance

Sparsity method: Kernel (Epanechnikov) using residuals

Bandwidth method: Hall-Sheather, bw $=0.1696$

Estimation successfully identifies unique optimal solution

\begin{tabular}{lrllr}
\hline \hline \multicolumn{1}{c}{ Variable } & Coefficient & Std. Error & t-Statistic & Prob. \\
\hline \hline \multicolumn{1}{c}{ DUMMYRUS } & 0.040600 & 0.068888 & 0.589359 & 0.5563 \\
\multicolumn{1}{c}{ C } & 1.401941 & 0.043991 & 31.86868 & 0.0000 \\
\hline \hline Pseudo R-squared & 0.002239 & Mean dependent var & 1.498785 \\
Adjusted R-squared & -0.003126 & S.D. dependent var & 0.391090 \\
S.E. of regression & 0.399848 & Objective & 28.44575 \\
Quantile dependent var & 1.419105 & Restr. objective & 28.50957 \\
Sparsity & 0.943840 & Quasi-LR statistic & 0.540964 \\
Prob(Quasi-LR stat) & 0.462033 & &
\end{tabular}


Dependent Variable: BETA

Method: Quantile Regression (Median)

Date: 04/26/16 Time: 17:02

Sample: 2000M01 2014M12

Included observations: 180

Huber Sandwich Standard Errors \& Covariance

Sparsity method: Kernel (Epanechnikov) using residuals

Bandwidth method: Hall-Sheather, bw $=0.17207$

Estimation successful but solution may not be unique

\begin{tabular}{lrlrr}
\hline \hline \multicolumn{1}{c}{ Variable } & Coefficient & Std. Error & t-Statistic & Prob. \\
\hline \hline \multicolumn{1}{c}{ DUMMY } & 0.210865 & 0.094883 & 2.222362 & 0.0275 \\
TC & -0.020112 & 0.022533 & -0.892543 & 0.3733 \\
TJ & 0.018858 & 0.008031 & 2.348181 & 0.0200 \\
C & 1.804056 & 0.825922 & 2.184292 & 0.0303 \\
\hline \hline Pseudo R-squared & 0.051266 & Mean dependent var & 1.473965 \\
Adjusted R-squared & 0.035095 & S.D. dependent var & 0.374131 \\
S.E. of regression & 0.370633 & Objective & 24.44660 \\
Quantile dependent var & 1.403548 & Restr. objective & 25.76762 \\
Sparsity & 0.839421 & Quasi-LR statistic & 12.58975 \\
Prob(Quasi-LR stat) & 0.005613 & & \\
\hline \hline
\end{tabular}

\section{1. África do Sul}

Dependent Variable: AFS

Method: Quantile Regression (Median)

Date: 10/29/15 Time: 13:48

Sample: 2000M02 2015M09

Included observations: 188

Huber Sandwich Standard Errors \& Covariance

Sparsity method: Kernel (Epanechnikov) using residuals

Bandwidth method: Hall-Sheather, bw $=0.1696$

Estimation successfully identifies unique optimal solution

\begin{tabular}{lclll}
\hline \hline \multicolumn{1}{c}{ Variable } & Coefficient & Std. Error & t-Statistic & Prob. \\
\hline \hline \multicolumn{1}{c}{ DUMMYAS } & 0.473866 & 0.065899 & 7.190746 & 0.0000 \\
C & 0.678605 & 0.043335 & 15.65962 & 0.0000 \\
\hline \hline Pseudo R-squared & 0.125131 & Mean dependent var & 1.160348 \\
Adjusted R-squared & 0.120427 & S.D. dependent var & 0.681739 \\
S.E. of regression & 0.664637 & Objective & 33.97836 \\
Quantile dependent var & 1.015973 & Restr. objective & 38.83822 \\
Sparsity & 0.926057 & Quasi-LR statistic & 41.98317 \\
Prob(Quasi-LR stat) & 0.000000 & & \\
\hline \hline
\end{tabular}

Dependent Variable: BETA

Method: Quantile Regression (Median)

Date: 04/26/16 Time: 17:04

Sample: 2000M01 2014M12

Included observations: 180

Huber Sandwich Standard Errors \& Covariance

Sparsity method: Kernel (Epanechnikov) using residuals

Bandwidth method: Hall-Sheather, bw=0.17207

Estimation successfully identifies unique optimal solution 


\begin{tabular}{cclll}
\hline \hline \multicolumn{1}{c}{ Variable } & Coefficient & Std. Error & t-Statistic & Prob. \\
\hline \hline \multicolumn{1}{c}{ DUMMY } & 0.498938 & 0.143454 & 3.478028 & 0.0006 \\
TC & 0.013183 & 0.033179 & 0.397335 & 0.6916 \\
TJ & 0.017090 & 0.023836 & 0.717007 & 0.4743 \\
C & 0.339611 & 0.473929 & 0.716587 & 0.4746 \\
\hline \hline Pseudo R-squared & 0.120391 & Mean dependent var & 1.157070 \\
Adjusted R-squared & 0.105398 & S.D. dependent var & 0.694658 \\
S.E. of regression & 0.684332 & Objective & 33.21383 \\
Quantile dependent var & 1.002606 & Restr. objective & 37.75978 \\
Sparsity & 0.954936 & Quasi-LR statistic & 38.08375 \\
Prob(Quasi-LR stat) & 0.000000 & & \\
\hline \hline
\end{tabular}




\section{APÊNDICE B}

Tabelas completas e/ou complementares da Análise Fatorial (Saída do SPSS)

\section{Eigenvalues da Análise Fatorial Não Passível de Utilização}

Total Variance Explained

\begin{tabular}{|c|c|c|c|}
\hline \multirow[t]{2}{*}{ Factor } & \multicolumn{3}{|c|}{ Initial Eigenvalues } \\
\hline & Total & $\%$ of Variance & Cumulative \% \\
\hline 1 & 20,009 & 76,958 & 76,958 \\
\hline 2 & 2,861 & 11,004 & 87,963 \\
\hline 3 & 2,240 & 8,615 & 96,578 \\
\hline 4 & ,632 & 2,431 & 99,009 \\
\hline 5 & , 156 & ,601 & 99,610 \\
\hline 6 & ,043 &, 167 & 99,777 \\
\hline 7 & 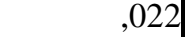 & ,084 & 99,861 \\
\hline 8 & - 013 & ,048 & 99,910 \\
\hline 9 & , 010 & ,037 & 99,947 \\
\hline 10 & , 006 & , 021 & 99,968 \\
\hline 11 & - 003 & , 013 & 99,981 \\
\hline 12 & , 002 - n & ,008 & 99,989 \\
\hline 13 & - 2001 & ,003 & 99,992 \\
\hline 14 & , 2001 & , 003 & 99,995 \\
\hline 15 & 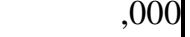 & ,002 & 99,997 \\
\hline 16 & ,000 & , 002 & 99,999 \\
\hline 17 & , 000 & ,001 & 99,999 \\
\hline 18 & $8,677 \mathrm{E}-005$ & ,000 & 100,000 \\
\hline 19 & 3,895E-005 & , 000 & 100,000 \\
\hline 20 & 2,959E-005 & ,000 & 100,000 \\
\hline 21 & $1,292 \mathrm{E}-005$ & 4,968E-005 & 100,000 \\
\hline 22 & 5,931E-006 & 2,281E-005 & 100,000 \\
\hline 23 & $1,136 \mathrm{E}-006$ & 4,370E-006 & 100,000 \\
\hline 24 & $6,778 \mathrm{E}-007$ & 2,607E-006 & 100,000 \\
\hline 25 & $3,247 \mathrm{E}-007$ & $1,249 \mathrm{E}-006$ & 100,000 \\
\hline 26 & $8,220 \mathrm{E}-010$ & 3,161E-009 & 100,000 \\
\hline
\end{tabular}

Extraction Method: Principal Axis Factoring.

\section{KMO e Teste Bartlett's da Análise Fatorial Não Passível de Utilização}

KMO and Bartlett's Test

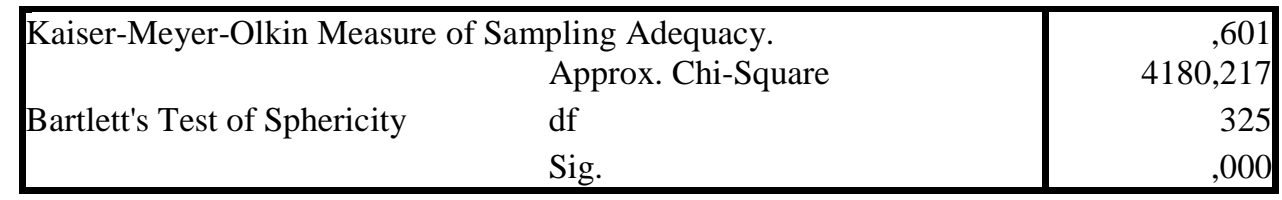

\section{Comunalidades das Variáveis Finais (Passível de Utilização)}

\begin{tabular}{|l|r|r|}
\hline \multicolumn{2}{|c|}{ Communalities } \\
\hline BS_CUR_ASSET_REPORT & \multicolumn{1}{|c|}{ Initial } & Extraction \\
\hline BS_CUR_LIAB & 1,000 &, 993 \\
BS_NET_FIX_ASSET &, 999 &, 978 \\
BS_TOT_ASSET &, 992 &, 941 \\
BS_TOT_LIAB2 & 1,000 &, 973 \\
CF_CASH_FROM_OPER & 1,000 &, 968 \\
CF_FREE_CASH_FLOW &, 996 &, 947 \\
\end{tabular}




\begin{tabular}{l|r|} 
EBIT &, 999 \\
EBITDA &, 998 \\
ENTERPRISE_VALUE &, 980 \\
IS_EPS &, 698 \\
IS_INC_TAX_EXP &, 994 \\
IS_OPER_INC &, 999 \\
PX_LAST &, 707 \\
RETURN_COM_EQY &, 860 \\
SALES_REV_TURN &, 914 \\
SHORT_AND_LONG_TERM_DE &, 998 \\
BT &, 999 \\
TOTAL_EQUITY &, 603 \\
WORK_CAP_GROWTH & 1,000 \\
\hline
\end{tabular}

Extraction Method: Principal Axis Factoring.

4. Eigenvalues do Conjunto de Dados (Passível de Utilização)

Total Variance Explained

\begin{tabular}{|c|c|c|c|c|c|c|}
\hline \multirow[t]{2}{*}{ Factor } & \multicolumn{3}{|c|}{ Initial Eigenvalues } & \multicolumn{3}{|c|}{ Extraction Sums of Squared Loadings } \\
\hline & Total & $\%$ of Variance & Cumulative \% & Total & $\%$ of Variance & Cumulative \% \\
\hline 1 & 12,422 & 65,380 & 65,380 & 12,374 & 65,126 & 65,126 \\
\hline 2 & 2,482 & 13,064 & 78,444 & 2,240 & 11,787 & 76,914 \\
\hline 3 & 1,432 & 7,535 & 85,979 & 1,144 & 6,022 & 82,936 \\
\hline 4 & 1,062 & 5,589 & 91,568 & ,649 & 3,415 & 86,351 \\
\hline 5 &, 571 & 3,006 & 94,574 & & & \\
\hline 6 & ,351 & 1,845 & 96,419 & & & \\
\hline 7 & ,231 & 1,214 & 97,633 & & & \\
\hline 8 & , 187 & ,986 & 98,619 & & & \\
\hline 9 & , 124 & 651 & 99,269 & & & \\
\hline 10 & ,067 & ,351 & 99,620 & & & \\
\hline 11 & ,033 & ,174 & 99,794 & & & \\
\hline 12 & ,018 & ,095 & 99,889 & & & \\
\hline 13 & ,011 & ,056 & 99,945 & & & \\
\hline 14 & ,007 & ,034 & 99,979 & & & \\
\hline 15 & ,002 & ,013 & 99,992 & & & \\
\hline 16 & ,001 & ,005 & 99,997 & & & \\
\hline 17 &, 000 & ,002 & 99,999 & & & \\
\hline 18 &, 000 &, 001 & 100,000 & & & \\
\hline 19 & $5,494 \mathrm{E}-007$ & $2,892 \mathrm{E}-006$ & 100,000 & & & \\
\hline
\end{tabular}

Extraction Method: Principal Axis Factoring.

\section{Matrix dos 4 Fatores Selecionados (Passível de Utilização)}

Factor Matrix ${ }^{\mathrm{a}}$

\begin{tabular}{|l|r|r|r|r|}
\hline \multirow{2}{*}{} & \multicolumn{4}{|c|}{ Factor } \\
\cline { 2 - 5 } & 1 & 2 & 3 & \multicolumn{1}{|c|}{. } \\
\hline BS_CUR_ASSET_REPORT &, 968 &,- 128 &,- 198 &,- 020 \\
BS_CUR_LIAB &, 965 &,- 078 &,- 167 &,- 112 \\
BS_NET_FIX_ASSET &, 935 &,- 143 &,- 215 &, 023 \\
BS_TOT_ASSET &, 981 &,- 075 &,- 067 &,- 009 \\
BS_TOT_LIAB2 &, 981 &,- 060 &,- 044 &,- 028 \\
CF_CASH_FROM_OPER &, 877 &, 188 &, 234 &,- 297 \\
CF_FREE_CASH_FLOW &, 786 &, 059 &, 274 &,- 330 \\
EBIT &, 928 &, 184 &, 197 &, 182 \\
EBITDA &, 976 &, 089 &, 020 &, 063 \\
ENTERPRISE_VALUE &,- 264 &, 882 &, 083 &,- 069 \\
IS_EPS &, 368 &,- 426 &, 515 &,- 221
\end{tabular}




\begin{tabular}{|c|c|c|c|c|}
\hline IS_INC_TAX_EXP & ,781 &, 542 & ,074 & ,233 \\
\hline IS_OPER_INC & ,936 & ,255 & ,076 & ,229 \\
\hline PX_LAST &,- 082 &,- 442 & 635 & ,212 \\
\hline RETURN_COM_EQY &,- 190 & ,701 & ,273 & 049 \\
\hline SALES_REV_TURN & ,991 &,- 016 &,- 097 &,- 020 \\
\hline $\begin{array}{l}\text { SHORT_AND_LONG_TERM_DE } \\
\text { BT }\end{array}$ & ,93 & 036 & ,127 &,- 022 \\
\hline TOTAL_EQUITY & ,943 &,- 169 &,- 211 &, 113 \\
\hline WORK_CAP_GROWTH &, 144 &,- 266 & ,155 & 423 \\
\hline
\end{tabular}

Extraction Method: Principal Axis Factoring.

a. 4 factors extracted. 11 iterations required.

6. Teste de Normalidade para o Índice selecionado sem a presença da IFRS segregado por país $($ Dummy $=0)$

Tests of Normality

\begin{tabular}{|ll|r|r|r|r|r|r|}
\hline \multirow{2}{*}{$\mathrm{i}$} & \multicolumn{4}{|c|}{ Kolmogorov-Smirnov $^{\mathrm{a}}$} & \multicolumn{3}{|c|}{ Shapiro-Wilk } \\
\cline { 3 - 8 } & Statistic & $\mathrm{df}$ & \multicolumn{1}{c|}{ Sig. } & Statistic & df & \multicolumn{1}{c|}{ Sig. } \\
\hline 1 & Indice &, 242 & 5 &, $200^{*}$ &, 932 & 5 &, 608 \\
2 & Indice &, 095 & 10 &, $200^{*}$ &, 988 &, 99 &, 994 \\
3 & Indice &, 211 & 5 &, $200^{*}$ &, 945 & 5 &, 703 \\
4 & Indice &, 151 & 5 &, $200^{*}$ &, 985 & 5 &, 961 \\
5 & Indice &, 271 & 5 &, $200^{*}$ &, 897 & 5 &, 392 \\
6 & Indice &, 127 & 9 &, $200^{*}$ &, 981 & 9 &, 967 \\
7 & Indice &, 115 & 11 &, $200^{*}$ &, 958 & 11 &, 746 \\
8 & Indice &, 156 & 7 &, $200^{*}$ &, 974 & 7 &, 927 \\
9 & Indice &, 265 & 5 &, $200^{*}$ &, 844 & 5 &, 175 \\
10 & Indice &, 156 & 7 &, $200^{*}$ &, 974 & 7 &, 927 \\
11 & Indice &, 239 & 5 &, $200^{*}$ &, 899 & 5 &, 405 \\
\hline
\end{tabular}

*. This is a lower bound of the true significance.

a. Lilliefors Significance Correction

7. Teste de Normalidade para o Índice selecionado com a presença da IFRS segregado por país (Dummy=1)

Tests of Normality

\begin{tabular}{|c|c|c|c|c|c|c|c|}
\hline \multirow[t]{2}{*}{ i } & & \multicolumn{3}{|c|}{ Kolmogorov-Smirnov ${ }^{a}$} & \multicolumn{3}{|c|}{ Shapiro-Wilk } \\
\hline & & Statistic & df & Sig. & Statistic & df & Sig. \\
\hline 1 & Indice & ,200 & 9 &, $200^{*}$ & ,931 & 9 &, 492 \\
\hline 2 & Indice & ,258 & 4 & & ,832 & 4 &, 174 \\
\hline 3 & Indice & ,262 & 9 & ,076 &, 850 & 9 & ,075 \\
\hline 4 & Indice & ,240 & 9 &, 142 &, 880 & 9 &, 156 \\
\hline 5 & Indice & 241 & 9 &, 140 & ,852 & 9 & 079 \\
\hline 6 & Indice & ,282 & 5 & ,200* & ,808 & 5 & ,094 \\
\hline 7 & Indice & ,249 & 3 & & ,967 & 3 & 653 \\
\hline 8 & Indice & ,205 & 7 & ,200* & ,897 & 7 & ,312 \\
\hline 9 & Indice & ,269 & 9 &, 059 & ,855 & 9 & , 086 \\
\hline 10 & Indice & ,208 & 7 & ,200* & ,892 & 7 & ,288 \\
\hline 11 & Indice & ,240 & 9 &, 143 & ,855 & 9 & ,085 \\
\hline
\end{tabular}

*. This is a lower bound of the true significance.

a. Lilliefors Significance Correction

8. Teste de Normalidade para o Índice selecionado sem a presença da IFRS para o conjunto dos países (Dummy=0) 
Tests of Normality

\begin{tabular}{|c|c|c|c|c|c|c|}
\hline & \multicolumn{3}{|c|}{ Kolmogorov-Smirnov ${ }^{\mathrm{a}}$} & \multicolumn{3}{|c|}{ Shapiro-Wilk } \\
\hline & Statistic & $\mathrm{df}$ & Sig. & Statistic & $\mathrm{df}$ & Sig. \\
\hline Indice &, 066 & 74 & ,200* & ,974 & 74 &, 125 \\
\hline
\end{tabular}

*. This is a lower bound of the true significance.

a. Lilliefors Significance Correction

9. Teste de Normalidade para o Índice selecionado com a presença da IFRS para o conjunto dos países (Dummy=1)

Tests of Normality

\begin{tabular}{|l|r|r|r|r|r|r|}
\hline \multirow{2}{*}{} & \multicolumn{4}{|c|}{ Kolmogorov-Smirnov } & \multicolumn{3}{c|}{ Shapiro-Wilk } \\
\cline { 2 - 7 } & Statistic & df & Sig. & Statistic & df & \multicolumn{1}{c|}{ Sig. } \\
\hline Indice &, 110 & 80 &, 018 &, 932 & 80 &, 000 \\
\hline
\end{tabular}

a. Lilliefors Significance Correction 


\section{Matrix Antiimagem}

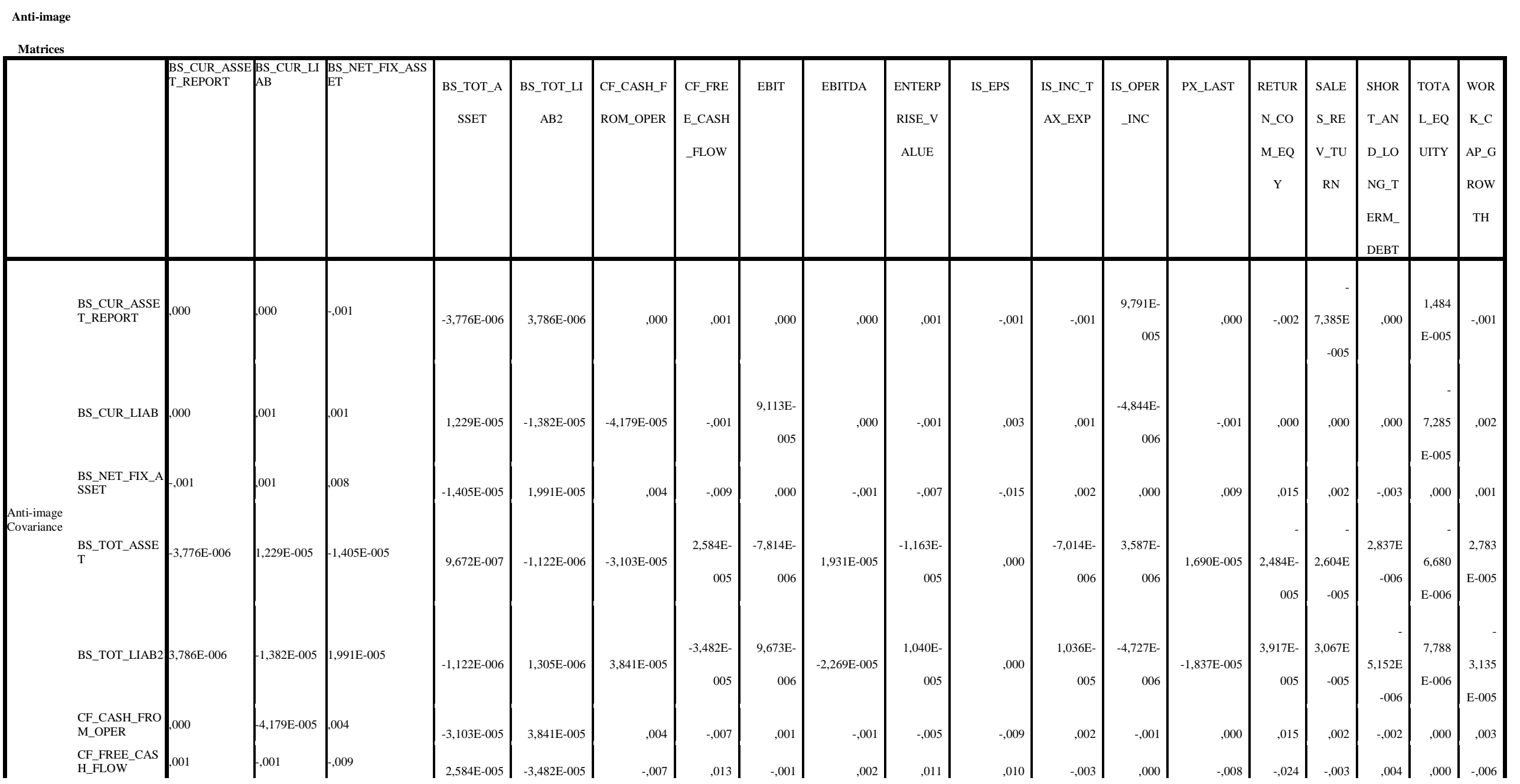



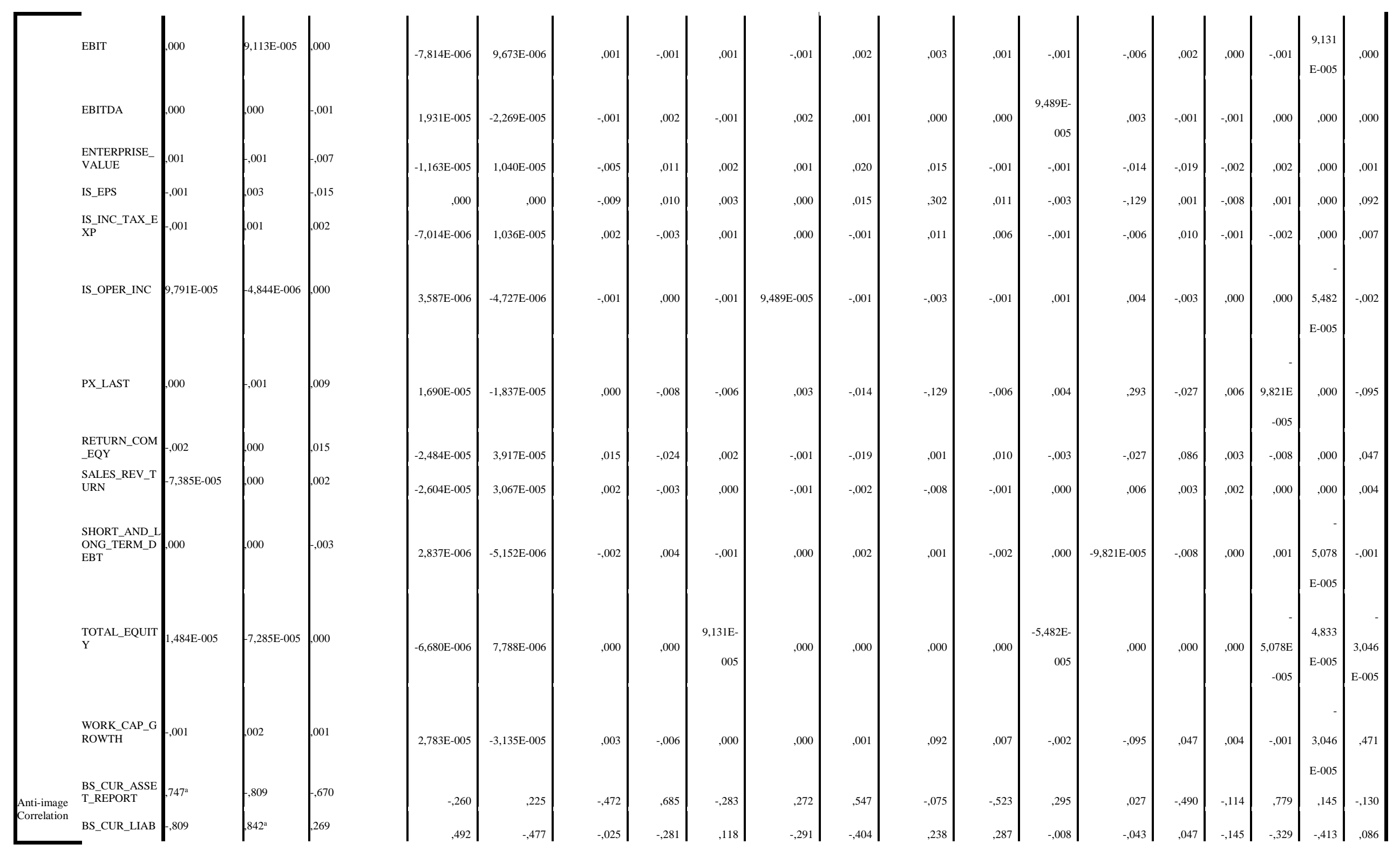


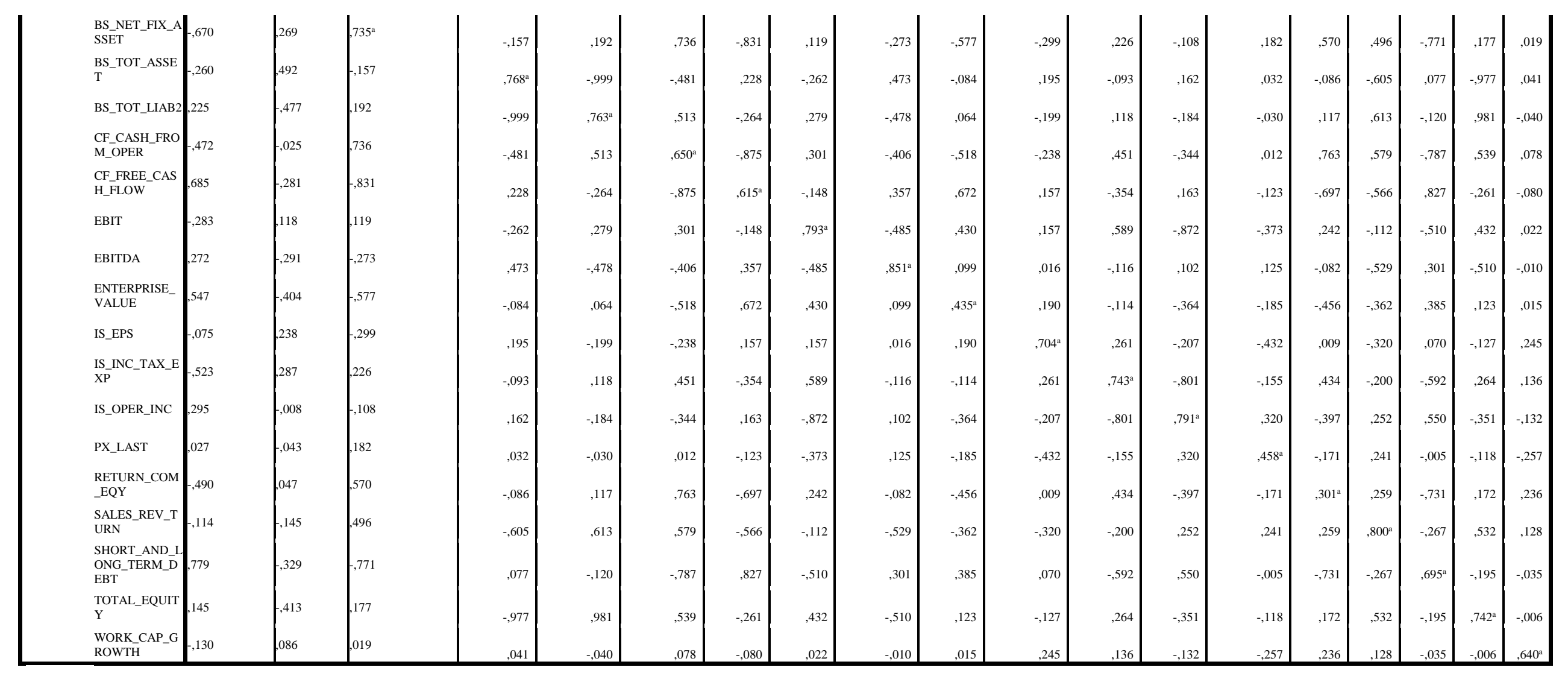

a. Measures

of

Sampling

Adequacy(

MSA) 


\section{APÊNDICE C}

Tabelas completas e/ou complementares da Regressão Logística (Saída do SPSS)

\section{Sumário dos Casos Processados}

Case Processing Summary
\begin{tabular}{|ll|r|r|}
\hline Unweighted Cases $^{\mathrm{a}}$ & & $\mathrm{N}$ & \multicolumn{1}{|c|}{ Percent } \\
\hline \multirow{3}{*}{ Selected Cases } & Included in Analysis & 154 & 93,3 \\
& Missing Cases & 11 & 6,7 \\
& Total & 165 & 100,0 \\
Unselected Cases & & 0 &, 0 \\
Total & & 165 & 100,0 \\
\hline
\end{tabular}

a. If weight is in effect, see classification table for the total number of cases.

\section{Codificação da Variável Dependente}

Dependent Variable Encoding

\begin{tabular}{|l|r|}
\hline Original Value & Internal Value \\
\hline 0 & 0 \\
1 & 1 \\
\hline
\end{tabular}

\section{Percentual geral de acerto nas classificações (Bloco 0)}

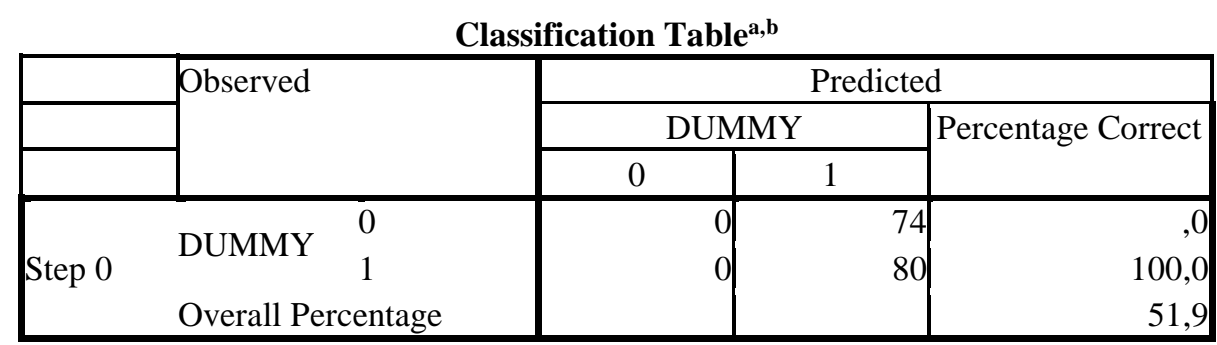

a. Constant is included in the model.

b. The cut value is ,500

\section{Variáveis dentro e fora da Equação (Bloco 0)}

\begin{tabular}{|ll|r|r|r|r|r|r|}
\hline & \multicolumn{1}{|c|}{ Variables in the Equation } \\
\hline Step 0 & Constant & & S.E. & Wald & df & Sig. & $\operatorname{Exp}(\mathrm{B})$ \\
\hline
\end{tabular}

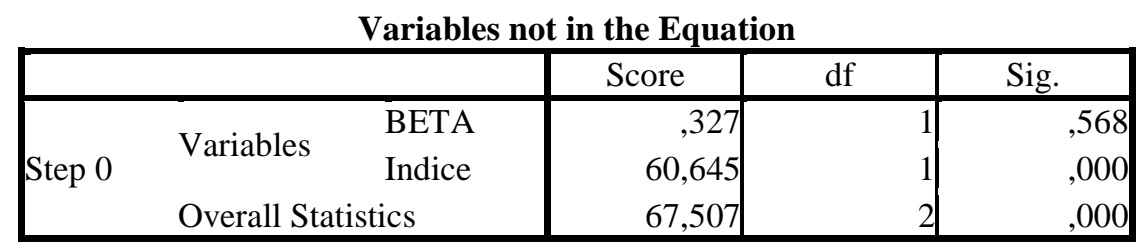

\section{Contingências para o teste de Hosmer e Lemeshow (Bloco 1)}

Contingency Table for Hosmer and Lemeshow Test

\begin{tabular}{|l|c|c|}
\hline DUMMY $=0$ & DUMMY = 1 & Total \\
\hline
\end{tabular}




\begin{tabular}{|c|c|c|c|c|c|c|}
\hline & & Observed & Expected & Observed & Expected & \\
\hline \multirow{10}{*}{ Step 1} & 1 & 15 & 14,789 & 0 & 211 & 15 \\
\hline & 2 & 15 & 14,198 & 0 & ,802 & 15 \\
\hline & 3 & 12 & 12,593 & 3 & 2,407 & 15 \\
\hline & 4 & 10 & 10,932 & 5 & 4,068 & 15 \\
\hline & 5 & 10 & 9,123 & 5 & 5,877 & 15 \\
\hline & 6 & 4 & 5,648 & 11 & 9,352 & 15 \\
\hline & 7 & 3 & 3,598 & 12 & 11,402 & 15 \\
\hline & 8 & 3 & 2,055 & 12 & 12,945 & 15 \\
\hline & 9 & 2 & ,886 & 13 & 14,114 & 15 \\
\hline & 10 & 0 & ,177 & 19 & 18,823 & 19 \\
\hline
\end{tabular}

\section{Capacidade Preditiva do Modelo (Bloco 1)}

Classification Table ${ }^{\mathrm{a}}$

\begin{tabular}{|c|c|c|c|c|}
\hline & \multirow[t]{3}{*}{ Observed } & \multicolumn{3}{|c|}{ Predicted } \\
\hline & & \multicolumn{2}{|c|}{ DUMMY } & \multirow[t]{2}{*}{ Percentage Correct } \\
\hline & & 0 & 1 & \\
\hline \multirow{3}{*}{ Step 1} & DUМMMY & 63 & 11 & 85,1 \\
\hline & Deinini & 14 & 66 & 82,5 \\
\hline & Overall Percentage & & & 83,8 \\
\hline
\end{tabular}

a. The cut value is ,500 